\title{
Job security in the Netherlands
}

Citation for published version (APA):

Frenk, M. M. (2013). Job security in the Netherlands. [Doctoral Thesis, Maastricht University]. Universitaire Pers Maastricht. https://doi.org/10.26481/dis.20130605mf

Document status and date:

Published: 01/01/2013

DOI:

10.26481/dis.20130605mf

Document Version:

Publisher's PDF, also known as Version of record

\section{Please check the document version of this publication:}

- A submitted manuscript is the version of the article upon submission and before peer-review. There can be important differences between the submitted version and the official published version of record.

People interested in the research are advised to contact the author for the final version of the publication, or visit the DOI to the publisher's website.

- The final author version and the galley proof are versions of the publication after peer review.

- The final published version features the final layout of the paper including the volume, issue and page numbers.

Link to publication

\footnotetext{
General rights rights.

- You may freely distribute the URL identifying the publication in the public portal. please follow below link for the End User Agreement:

www.umlib.nl/taverne-license

Take down policy

If you believe that this document breaches copyright please contact us at:

repository@maastrichtuniversity.nl

providing details and we will investigate your claim.
}

Copyright and moral rights for the publications made accessible in the public portal are retained by the authors and/or other copyright owners and it is a condition of accessing publications that users recognise and abide by the legal requirements associated with these

- Users may download and print one copy of any publication from the public portal for the purpose of private study or research.

- You may not further distribute the material or use it for any profit-making activity or commercial gain

If the publication is distributed under the terms of Article $25 \mathrm{fa}$ of the Dutch Copyright Act, indicated by the "Taverne" license above, 


\section{Job Security in the Netherlands}

Myrthe Maria Frenk 
(C) Copyright Myrthe Frenk, Maastricht 2013.

All rights reserved. No part of this thesis may be reproduced of transmitted in any form of by any means, electronic or mechanical, including photocopying, recording, or any information storage or retrieval system without permission from the author, or when appropriate, from the publishers of the publications.

Alle rechten voorbehouden.

Niets uit deze uitgave mag worden verveelvoudigd, opgeslagen in een geautomatiseerd gegevensbestand en/of openbaar gemaakt in enige vorm of op enige wijze, hetzij elektronisch, mechanisch, door fotokopieën, opnamen of op enige andere manier zonder voorafgaande schriftelijke toestemming van de uitgever. 


\title{
Job Security in the Netherlands
}

\author{
Proefschrift
}

Ter verkrijging van de graad van doctor aan de Universiteit Maastricht, op gezag van de Rector Magnificus, Prof dr. L.L.G. Soete volgens het besluit van het College van Decanen,

in het openbaar te verdedigen op woensdag 5 juni 2013 om 16.00 uur

door

Myrthe Maria Frenk

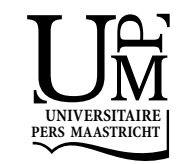




\section{Promotor}

Prof. dr. Gerard Pfann

\section{Beoordelingscommissie}

Prof. dr. Hetty van Emmerik (voorzitter)

Prof. dr. Thomas Dohmen

Prof. dr. Wolter Hassink (Universiteit Utrecht) 


\section{Acknowledgements}

Four years have flown by. The decision to start a Ph.D. was probably one of the better decisions I have ever made. During these four years I met people that are now very dear to me. Moreover, I learned a lot. About research, but also about myself.

It was not always easy, I must admit. I had the fortune to have Prof. dr. Gerard Pfann as my supervisor. We met often. Obviously, we talked about research. Gerard, your clear vision, your patience and your talent for explaining complicated issues in ways that all can understand made my life as a PhD candidate so much easier. During our meetings we also talked about issues other than research. Your warm personality makes it very easy and enjoyable to work with you. I deeply appreciate your support during the last four years. I hope that we stay in contact.

During my PhD project I met other people that I would like to thank. They appear here in no particular order. Thank you, dr. Wilko Letterie for your valuable comments and for our discussions about the Dutch employment protection system. Thank you Prof. dr. Thomas Dohmen, Prof. dr. Hetty van Emmerik and Prof. dr. Wolter Hassink, for assessing my thesis and providing me with useful feedback. It goes without saying that errors and omission left in the thesis are entirely mine. Adela Buttolo and Anita Weijzen, your kindness and help is very much appreciated. Thank you Jaap Juursema, Ronald Kamminga, and Jan Meijer of the UWV and John Scaf of the civil court in Maastricht for helping me understand the PES and civil court dismissal process and for your role in giving me access to the data. Thank you Tamara and Eva, for your excellent assistance in gathering and processing the data.

I would like to thank you, Charlotte, Elena and Anna, for your warm friendship and for all the time (a lot!) we spent together. Together with Antonio, Jan, Eric, Maciek and Martin. What a great time we had! The 2010 FIFA Worldcup, our weekends away, and not to mention our numerous encounters at Zondag and Take5. Special thanks, Sebastian, for being such a wonderful office mate and friend. I always felt at home in the office because of you. Eva, I am glad that you decided to stay in Maastricht. Thank you.

Some people were not directly part of my PhD experience in Maastricht but supported me from a distance. Carolien, thank you for being the close friend that you are and for letting me stay the summer of 2010 in your house in Amsterdam. Faytwan, your listening ear and your valuable advice on life is always appreciated. Bart, I consider myself very lucky to have you as a twin brother and friend. Who would have thought 32 years ago that we would both become $\mathrm{dr}$. Frenk 32 years later? I am grateful to you, Hans and Jikke, my parents, for your unconditional love and support. Although we do not live close to each other, it never feels you are far away. Last but not least, thank you, dear Jasper. For everything. 


\section{Table of contents}

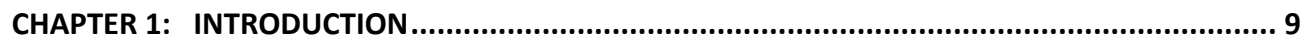

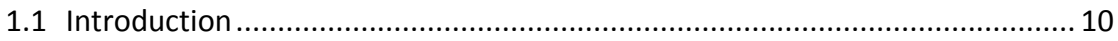

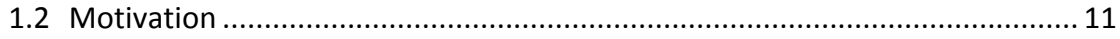

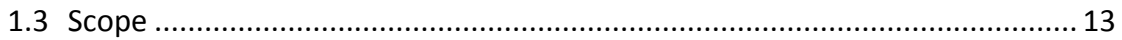

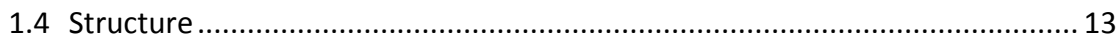

CHAPTER 2: DUTCH EMPLOYMENT PROTECTION LEGISLATION: CURRENT LAW AND

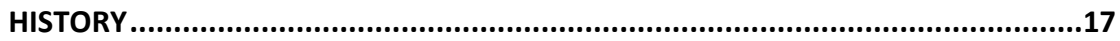

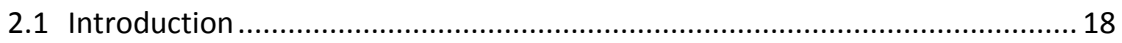

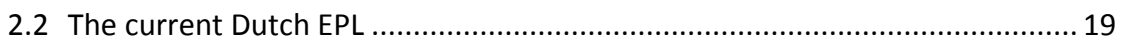

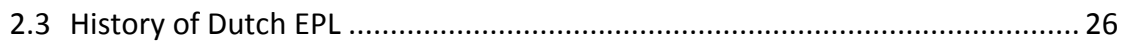

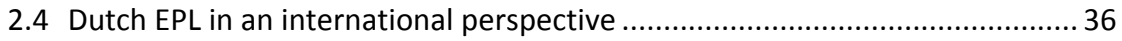

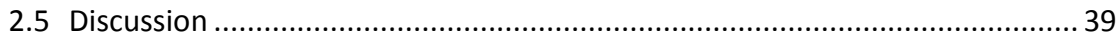

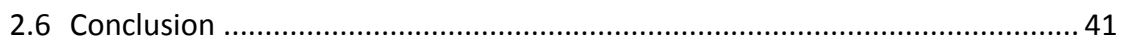

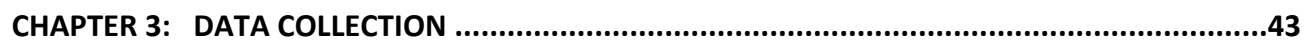

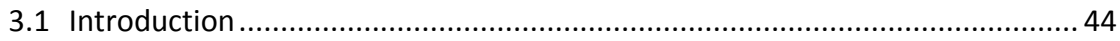

3.2 Data storage at both institutes ............................................................. 45

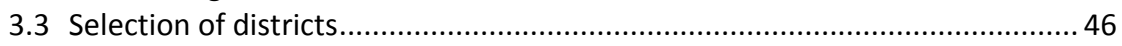

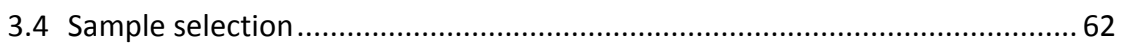

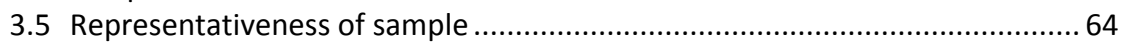

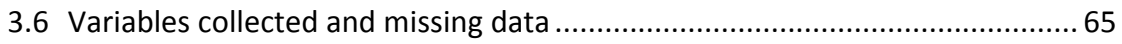

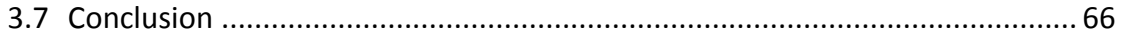

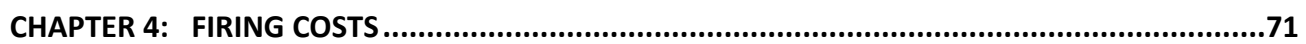

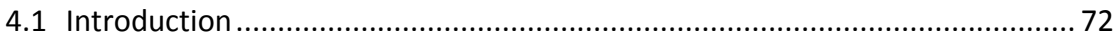

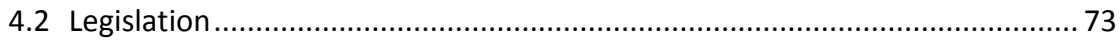

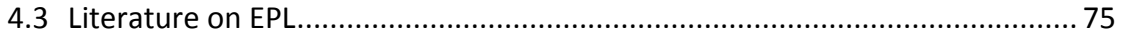

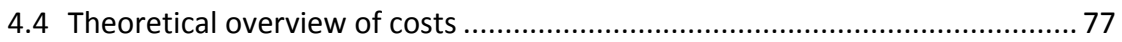

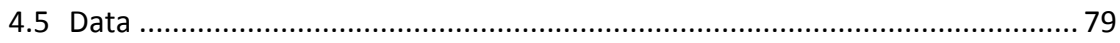

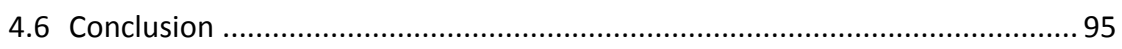

CHAPTER 5: JOB SECURITY AND SEVERANCE PAY LENIENCE IN RECESSION .........................101

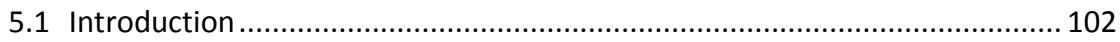

5.2 Some characteristics of European labor markets..................................... 103

5.3 Duality in the Dutch labor market............................................................ 107

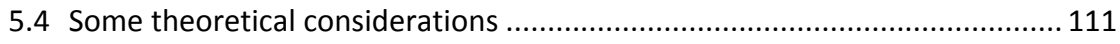

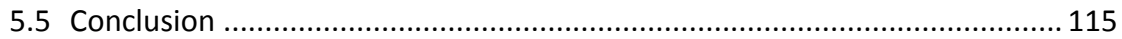

CHAPTER 6: RECESSION INDUCED REQUESTS AND THE LIKELIHOOD OF SUCCESS.................117

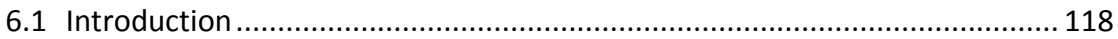

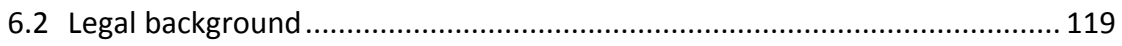




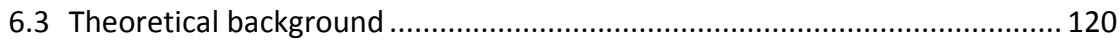

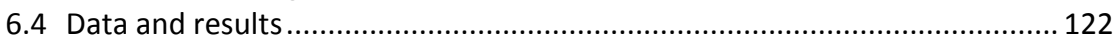

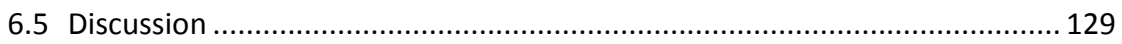

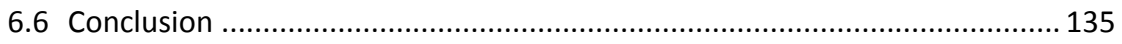

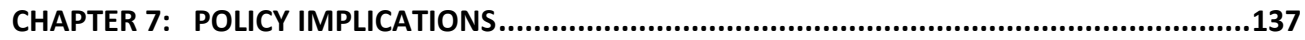

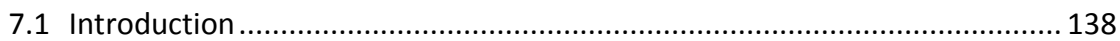

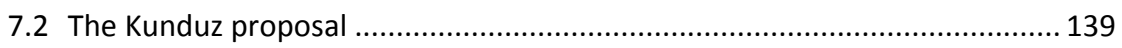

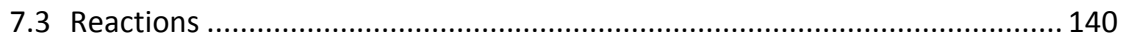

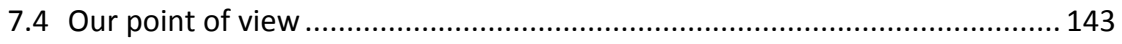

7.5 Some cost calculations: the current system versus the newly proposed

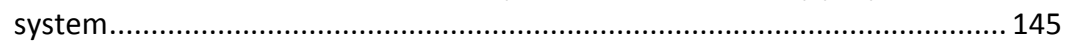

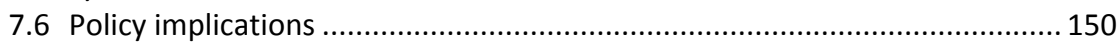

7.7 Outlook for future research .............................................................. 152

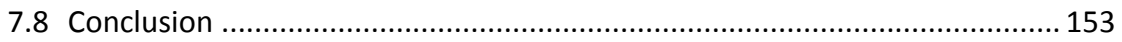

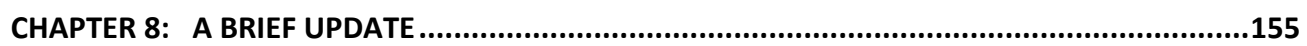

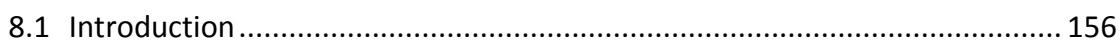

8.2 Some cost calculations...................................................................... 157

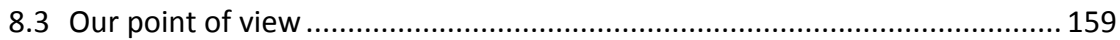

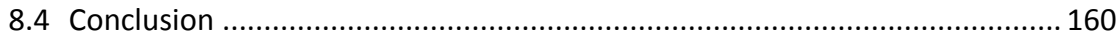

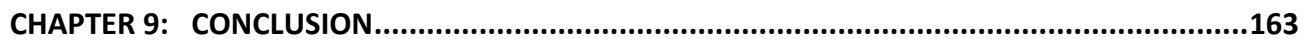

NEDERLANDSE SAMENVATTING (DUTCH SUMMARY) .................................169

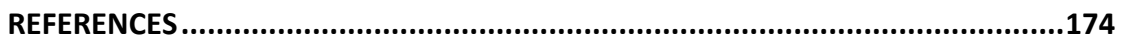

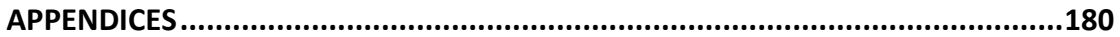

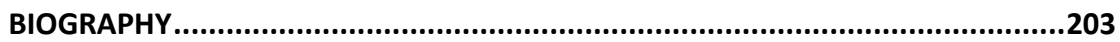



CHAPTER 1:

INTRODUCTION 


\subsection{Introduction}

The Dutch employment protection legislation (EPL) ${ }^{1}$ regarding the firing of permanent workers is unique in the world. It so happens that the Netherlands has two institutes responsible for the enforcement of employment protection law. The first institute is the public employment service $(\mathrm{PES})^{2}$, which operates under close supervision of the Dutch government ${ }^{3}$. It remains from a decree that has been enforced during the occupation of the Netherlands during World War II. The second institute is the universal civil court. The check for the fairness of the dismissal is a preventative check, not a repressive one. As such, the PES and the civil court intervene at an early stage of the dismissal process and therefore shape the dismissal protection for employees with a permanent contract more directly. The OECD refers to the Dutch system as a "dual system" of dismissal (OECD, 2004). More specifically, this dual system entails that an employer, when intending to terminate a permanent employment contract of one his employees, may either request the PES for a dismissal permission or may ask the civil court to dissolve the contract. This given, it is the employer who is the plaintiff, and the employee who is the defendant. In countries that apply a repressive check these roles are reversed.

The two separate dismissal procedures are rather different. Both institutes follow a different set of legal rules. The PES follows the regulations that are recorded in the Extraordinary Labor Relations Decree ${ }^{4}$ and the Dismissal Decree ${ }^{5}$. Dismissal permission is given if dismissal is judged to be fair. Fair dismissals are dismissals based on economic grounds (e.g redundancy), dysfunctional behavior, a disturbed employment relationship, illness and misconduct. Rules followed by the civil court are governed by the Civil Code of Law. The civil court will rescind an employment contract if a substantial reason exists. A substantial reason is a circumstance that would have also allowed for an immediate dismissal. Examples are fraud, incompetence, drunkenness, theft and reckless behavior. A substantial reason also refers to a circumstantial change that justifies the termination of an employment relationship. Examples are economic circumstances, a disturbed employment relationship and long-term illness. In practice, the majority of economic dismissals is filed at the PES. The civil court route is a more popular route to dismiss a worker that is underperforming. Generally speaking, the civil court procedure is the quickest route and the likelihood that the contract is dissolved is high. On average it is also the most expensive route because courts may require employers to award employees a severance pay. The PES procedure is longer. Severance pay, however, is not required. There is no appeal possible against the decision made by either civil court or the PES. Nonetheless, after being dismissed via the PES route, the employee concerned may ask the court for compensation for unfair dismissal. This, however, occurs in less than $1 \%$ of all cases. ${ }^{6}$

\footnotetext{
${ }^{1}$ In this dissertation EPL is used as an acronym for Employment Protection Legislation.

${ }^{2}$ In this chapter we use PES as an acronym for public employment service. The official Dutch name for the PES is Uitvoerings Instituut Werknemersverzekering (UWV). In this dissertation, if we refer to the PES, we mean the UWV, and in particular the legal department of UWV that is responsible for handling dismissal requests. In this chapter we use PES as an acronym for public employment service.

${ }^{3}$ If we refer to the government, we mean all Ministers and all Secretaries of State. In the Netherlands we distinguish between a "government", which is composed of all Ministers and the Queen, and a "cabinet" which is composed of all Ministers and all Secretaries of State.

${ }^{4}$ In Dutch: Buitengewoon Besluit Arbeidsverhoudingen.

${ }^{5}$ In Dutch: Ontslagbesluit.

${ }^{6}$ Source: Data obtained from the civil court Maastricht.
} 
After publication of the studies "Regulation or deregulation of the labour market. Policy regimes for the recruitment and dismissal of employees in industrialized countries" of Michael Emerson (1988), "Job security provisions and employment" of Ed Lazear (1990), and "Job security, employment and wages" of Guiseppe Bertola (1990) policymakers became widely interested in examining the effect of EPL on labor market outcomes. Since, the OECD calculates the Employment Protection Legislation Index (EPL-Index) for a large number of its member states. According to this index, the Netherlands is marked with one of the strongest employment protection laws for workers with job tenure. Among the EU15 countries, only Portugal and Germany have stricter labor markets for tenured workers.

A common perception is that extensive regulation is associated with the failure of Western European labor markets and their inability to adapt to changing conditions (OECD, 1994; Bertola and Rogerson, 1996; Bentolila and Bertola, 1990). Even though different interpretations are found in literature, like efficiency wages (Yellen, 1984) or hysteresis and the 1980's disinflation policies (Ball, 1996), most authors agree that EPL plays an important role. As a reaction to the idea that strict regulation leads to poor labor market outcomes, different European institutions have encouraged their member states to reduce the strictness of their EPL system. The OECD Jobs Study (1994, p50) advised to "loosen mandatory restrictions on dismissals in countries where current provisions appear to seriously hinder economic restructuring and the hiring chances of new labor force entrants." The European Commission and the International Labor Office have made similar recommendations. (European Commission, 2003, ILO, 2005).

\subsection{Motivation}

Ever since the foundation of the dual system in World War II, Dutch EPL is criticized. Different governments have attempted to modify the system, almost all proposing to introduce a simpler system with only one institute responsible for the enforcement of labor law. Over time, different committees were installed and the Corporation of Labor ${ }^{7}$ was asked for advice. The newly proposed modifications were never introduced. Directly after the War, the Corporation of Labor concluded that the Netherlands was not ready for the abolishment of the PES route until a judicial check on the reasonableness check of the dismissal existed. ${ }^{8}$ Even when such a check was introduced in 1953, the system remained intact. ${ }^{9}$ After 1953, all bills in favor of a modification were withdrawn as different political parties could not reach mutual agreements.

The idea for this dissertation stems from one of the most recent attempts made. In a request for advice, dated July 3 2007, the former Minister of Social Welfare and Employment, Piet Hein Donner, notifies the Corporation of Labor about his ideas to "improve" the Dutch EPL. One of the most important aspects of his proposal is a singular regulation of employment protection in the Civil Code of Law. The improvements suggested are driven by the general idea that the rigidness of the Dutch dual system has led to a situation in which the relatively high firing costs have led to a poor functioning labor market. A more flexible EPL is supposed to

\footnotetext{
${ }^{7}$ In Dutch: Stichting van de Arbeid.

8 "Herziening van het ontslagrecht: advies uitgebracht door het bestuur van de Stichting van de Arbeid aan de Minister van Justitie" Den Haag: Stichting van de Arbeid 1947, p28.

${ }^{9}$ In 1953, the Dutch government rejected a motion in favor of the abolishment of the PES route with slight majority (Drongelen, van \& Rijs, van, 2008).
} 
increase labor participation, especially among older employees, younger employees and women (AV/IR/2007/23064). The plans of Minister Donner are heavily criticized, political parties do not seem to agree and employees' organizations are strictly against. This political impasse led to the establishment of the Commission Labor Participation ${ }^{10}$ in December 2007. When delivering its advice, the commission mainly focused on which measures have to be taken in order to bear the costs of the aging population. Liberalization of the employment protection system is hardly discussed. Again, the duality in the Dutch system of job security provisions remained untouched.

A huge part of the problem is created by the fact that we do not know whether the relatively high firing costs of the current Dutch dismissal system lead to a decrease, or to an increase in productivity and employment. Literature on the effect of EPL on different labor market outcomes draws many different conclusions. Reasons for divergence in results are differences in settings, different measures of EPL, but also the use of different methods. This leaves room for severe debates and divides the cabinet into opponents and advocates of a more liberal EPL. Agreements are not reached because the expected outcomes of certain proposed modifications are not testable.

We observed that detailed knowledge about the Dutch system is lacking. Although the international discussion about EPL is to a large extent a discussion about the effect of firing costs on the functioning of the labor market, an up-to-date approximation of the firing costs of both separate procedures, PES and civil court, does not exist. Neither do we know the specifics behind the choice for the PES or the civil court route. What type of employees and employers are involved? Which reasons for dismissal prevail at both routes? We furthermore observed that between 1998 and 2008, the two routes were chosen in almost equal proportions. ${ }^{11}$ For economists a balanced decision between both routes is an indication that both routes are of equal importance for the termination of the employment contract. On itself, the option to choose is an indication of labor market flexibility. Abolishing one of the two routes results in more rigidity because decisions are made under stricter requirements.

We realized that the Dutch labor market deserves some special attention. Little is known and heard about the positive aspects of Dutch EPL. Although we cannot give a more clear cut answer to the question how EPL affects different labor market outcome in general, we do know that the Dutch labor market is an example that challenges modern theories of unemployment and worker protection. Although being marked with one of the strongest regulations for permanent workers, the Netherlands outperforms most EU15 countries in terms of employment and worker productivity.

Five years have passed since the proposal of Minister Donner in 2007. The Dutch EPL has been left untouched. For how long is uncertain. In May 2012 the Kunduz ${ }^{12}$ parties VVD, CDA, D66, GroenLinks and ChristenUnie agreed that Dutch EPL will be drastically revised in 2014. The new proposition made follows the trend that was set by Minister Donner in 2007 and aims for the abolishment of the dual system.

\footnotetext{
${ }^{10}$ In Dutch: Commissie Arbeidsparticipatie.

${ }^{11}$ In 2008, the effects of the Great Recession became tangible and the number of requests filed at the PES became twice the amount as the requests filed at the civil court.

${ }^{12}$ Because of an earlier mutual agreement to support the police training missing in the Afghan province of Kunduz, the media started referring to these parties as the Kunduz parties.
} 


\subsection{Scope}

According to the definition of the OECD, employment protection legislation (EPL) " refers both to regulations concerning hiring (e.g. rules favoring disadvantaged groups, conditions for using temporary or fixed term contract, training requirements) and firing (e.g. redundancy procedures, mandated pre-notification periods and severance payments, special requirements for collective dismissals and short-time work schemes)" (OECD, 1999, p50).

The Dutch discussion is mainly a discussion about the stringent dismissal regulation for permanent workers. Therefore, the general focus of this dissertation is on the firing component of EPL, and more specifically on the firing of permanent employees. It furthermore focuses on the termination of the employment contract by dismissal via the PES and the civil court. Other options to terminate an employment contract are at will during the trial period, termination by mutual consent, termination by operation of law ${ }^{13}$ and by summary dismissal. These options are beyond the reach of this dissertation. ${ }^{14}$

\subsection{Structure}

The structure of this thesis is as follows. Chapter 2 presents an overview of the Dutch EPL. It commences with a description of the regulations regarding the termination of an employment contract by dismissal via the PES and via the civil court. It continuous with a sketch of history. The first milestone in history is the introduction of the old Civil Code of Law, which introduced a new national civil law that contained three articles regarding the employment relationship between an employer and an employee. Originally, these articles were all written to protect the employer, not the employee. The introduction of the first legislative measures that aimed for the protection of the employee was not until 1909 when the Law on Employment Contracts ${ }^{15}$ was enacted. The Law on Employment Contracts resulted in the introduction of the preventative check by the civil court. Moreover, periods of notice were introduced. The PES route of dismissal was introduced when the occupying force of Nazi Germany enacted the First Enforcement Resolution ${ }^{16}$ on June 11th 1940. After the war the Dutch government upheld this resolution through the declaration of the Extraordinary Labor Relations Decree ${ }^{17}$ of October $5^{\text {th }}, 1945$. Uniquely, the dual system still exists today. We continue Chapter 2 by placing the Netherlands in

\footnotetext{
${ }^{13}$ A termination of an employment contract by operation of law may imply the expiry of a fixed term contract or the death of an employee.

${ }^{14}$ An estimation of the distribution of dismissal cases over the different termination options is given by a survey conducted in 2001 (Research and Beleid, 2001), which investigates the relationship between the flow into unemployment benefit and the different options to terminate an employment contract. This research indicates that in $52 \%$ of all cases termination of an employment contract occurs because of the expiration of a fixed term or temporary contract. $6 \%$ is termination by mutual consent. $3 \%$ is terminated during the trial period. $21 \%$ of contracts is terminated either via the PES (10\%) or via the civil court procedure $(11 \% \%) .2 \%$ of contracts is terminated without permission, $1 \%$ of contracts is terminated by summary dismissal, $12 \%$ is a rest category and $3 \%$ is unknown $(n=2,263)$. To our knowledge, a more recent estimation does not exist.

${ }^{15}$ In Dutch: Wet op de Arbeidsovereenkomst. This law was passed in 1907 and enacted in 1909.

${ }^{16}$ In Dutch: Eerste Uitvaardigingsbesluit.

${ }^{17}$ In Dutch: Buitengewoon Besluit Arbeidsverhoudingen.
} 
an international context and end with a discussion on why the proposed modifications of the Dutch EPL were never enacted.

We have collected a sample of 3,391 individual dismissal requests containing workers' and employers' information, of which 1,134 requests are filed at PES in the period 2006-2009 and 2,257 requests are filed at the civil court in the period 2003-2009. This collected sample is unique and is used for the analyses in Chapter 4 to 7 of this dissertation. Data collection was not an easy task since the civil court does not store employers' and employees' information electronically. The PES does this only partly. Most information on a case is kept in hard copy dismissal files that are stored in an archive. Data have been collected manually. Chapter 3 presents all specifics of the data collection method.

Chapter 4 continues with a comparative analysis of firing cost differences between the two separate procedures. We contribute to existing literature by providing an up-to-date overview of costs. Hassink, Reitsma and Roorda (1998) estimated firing costs of both procedures in the 90's. The more recent research of Knegt and Tros (2007) made similar calculations. Both studies use self-reported measures to calculate firing costs. Actual costs are not observed. We use a representative sample containing actual data of firing disputes. Instead of estimating firing costs, we observe costs using information on the wage, the duration of the dismissal process and the actual amount of severance pay awarded. This results in a more precise estimation. We find that, on average, firing costs by civil courts are four times larger than firing costs of PES dismissals. The difference in costs between both procedures is a result of the fact that employers are relieved from the obligation of severance payment when the PES grants a request.

In Chapter 5, we show that the Dutch labor market is an example that challenges modern theories of unemployment and worker protection. Despite of being marked with one of the strongest regulations for permanent workers, the Netherland outperforms most other European countries in terms of unemployment, labor participation and worker productivity. Moreover, we compare the two separate procedures in terms of workers' and employers' characteristics. We show that larger employers go to the civil court more often. Medium sized firms are more likely to follow the PES route of dismissal. Additionally, the employees involved in the civil court route earn slightly higher wages. We continue Chapter 5 with introducing the idea that the Dutch system can be viewed as a system of the government relieving firms in demise to pay severance. This is a unique feature of the Dutch labor market. We present a simple theoretical equilibrium model of employment determinations of firms that have the opportunity to receive severance pay exemption when facing economic distress. The model predicts that a system of severance payment exemption is less costly than the alternative of additional unemployment benefits as long as the wage elasticity of labor demand does not exceed the inverse of the replacement ratio.

Chapter 6 shows that the number of PES dismissal requests and number of civil court dismissal requests increases with increasing unemployment rates. This holds true for both economic and noneconomic requests. Under the assumption that the judicial decision is independent of the state of the economy, we provide evidence that these recession induced cases that are filed at the PES procedure are weaker cases from a plaintiff's perspective. We define a weaker case as a case that does not, partly or fully, comply with the definition of a fair dismissal as stipulated in the Dutch code of law. Recession induced cases filed at the PES have a smaller likelihood of being granted. These results are desirable from a judicial perspective 
because they imply that the PES does not allow an employer to terminate a permanent employment contract without a reasonable cause. For the civil court we do not find evidence that recession induced cases are of lower quality. A possible explanation for this finding is that the assumption of judicial independence is a too strong assumption to make for the civil court. Further research is needed to clarify this issue.

In Chapter 7 we present the latest proposal of the Kunduz ${ }^{18}$ parties VVD, CDA, D66, GroenLinks and ChristenUnie to drastically revise the Dutch EPL. ${ }^{19}$ In short, the proposal argues for the abolishment of the preventative check of dismissal and for the introduction of a budget that is used for schooling purposes. The proposal furthermore argues for the financing of the first months of the unemployment benefit by the employer. We continue Chapter 7 by sketching an overview of the reactions the new proposal has provoked. We summarize a letter of protest that was sent by a delegation of scientist to the Upper Chamber, dated June 11th $2012 .^{20}$ We furthermore present opinions from a workers' employers' and voters' perspective. Next, we present our point of view. We are against the proposed measures and are in favor of the maintenance of the dual system of employment protection. To put strength to the view to reject the new proposed measures, we additionally show that the proposed system will not lead to a decrease in firing costs. We conclude Chapter 7 by proposing an outlook for future research and by presenting the policy implications of our research.

Recent political developments have motivated us to write a brief update. Chapter 8 describes the measures as proposed in the Coalition Agreement ${ }^{21}$ of October $29^{\text {th }} 2012$. We present a short overview of the agreement, calculate the costs of the newly proposed measures and express our point of view.

\footnotetext{
${ }^{18}$ Because of an earlier mutual agreement to support the police training missing in the Afghan province of Kunduz, the media started referring to these parties as the Kunduz parties.

${ }^{19}$ In the Spring Agreement of May 2012 the political-parties VVD, CDA, D66, GroenLinks and ChristenUnie proposed a new drastic revision of the current Dutch EPL. This proposal was revised and sketched in more detail by Henk Kamp, (outgoing) Minister of Social Affairs and Welfare and was send to the Upper Chamber at the $18^{\text {th }}$ of June 2012.

20 See "Hoogleraren kraken versoepeling ontslagrecht". Volkskrant June 12th 2012. www.volkskrant.nl/vk vk/nl/10637/VK-Dossier-Verkiezingen-van-2012/article/detail/3269984/2012/06/12/Hoogleraren-krakenversoepeling-ontslagrecht.dhtml, retrieved September 11th 2012.

${ }^{21}$ In Dutch: Regeerakkoord.
} 

CHAPTER 2:

DUTCH EMPLOYMENT PROTECTION

LEGISLATION: CURRENT LAW AND HISTORY 


\subsection{Introduction}

In the Netherlands, the set of rules governing the hiring and firing of employees is rather complex. Unlike in most OECD countries, the Netherlands has two institutes responsible for the enforcement of labor law: the public employment service (PES) $)^{22}$ and the civil court. The OECD refers to the Dutch system as a "dual system" of dismissal (OECD 2004). The check for the fairness of the dismissal is a preventative check, not a repressive one. As such, the PES and the civil court are involved at an early stage of the dismissal process. It also implies that the employer is the plaintiff and the employee the defendant. ${ }^{23}$ The Dutch system is unique in the world.

In Section 2 of this chapter we present an overview of the current Dutch employment protection legislation (EPL) ${ }^{24}$. The duality of the Dutch system, together with the preventative nature of the dismissal check, implies that a Dutch employer may dismiss a permanent worker by either requesting prior permission from the PES, or by requesting the civil court to dissolve the employment contract. The PES is a public institute, supervised by the Minister of Social Affairs and Employment; the civil court is an independent legal body. Both apply a different set of laws. Rules regarding dismissal via the PES are recorded in the Extraordinary Labor Relations Decree $^{25}$ (ELRD) and the Dismissal Decree ${ }^{26}$ (DD). Termination of employment via the civil court is governed by the Civil Code ${ }^{27}$ (CC). Besides termination by dismissal, an employment contract may also be terminated at will during the trial period, by mutual consent, by operation of law ${ }^{28}$ and by summary dismissal. As mentioned earlier, these options are beyond the scope of this dissertation.

We continue this chapter by looking back into the past. An historical overview of the evolution of Dutch EPL that is given in Section 3 allows us to understand the system as it exists today. We commence with describing a milestone in the history of Dutch employment protection: the introduction of the old Civil Code of Law in 1838. The Civil Code introduced the concept of contractual freedom, which was quite revolutionary at that time. Despite this contractual freedom, the worker remained inferior to the master, who determined the content of the contract. As a result of the Industrial Revolution at the second half of the $19^{\text {th }}$ century working conditions deteriorated and social injustice increased. A general protest against this rising social injustice resulted in the enactment of the first modest labor laws. Labor for children

\footnotetext{
${ }^{22}$ In this chapter we use PES as an acronym for public employment service. The official Dutch name for the PES is Uitvoerings Instituut Werknemersverzekering (UWV). In this dissertation, if we refer to the PES, we mean the UWV, and in particular the legal department of UWV that is responsible for handling dismissal requests.

${ }^{23}$ The Netherlands also knows a repressive check of dismissal. The employee that is dismissed may file a request at the civil court for being manifestly unreasonably dismissed (sec. 7:682 CC). This check, however, is not often used. At the Maastricht civil court, over the years 2003-2009, this procedure is followed an average amount of 36 times per year. The average amount of preventative dismissal procedures that was followed at this court was 2,025 procedures per year. For the same period, the average number of preventative cases at the PES district Maastricht was 3,700.

${ }^{24} \mathrm{EPL}$ is used as an acronym for employment protection legislation.

${ }^{25}$ In Dutch: Buitengewoon Besluit Arbeidsverhoudingen.

${ }^{26}$ In Dutch: Ontslagbesluit.

${ }^{27}$ In Dutch: Burgerlijk Wetboek.

${ }^{28}$ A termination of an employment contract by operation of law may imply the expiry of a fixed term contract or the death of an employee.
} 
under 12 became forbidden, maximum working hours were set and protection measures against working hazards in the industry were introduced. It was not until the Law on Employment Contracts of 1907, when employees received some legal rights. The preventative check by the civil court was introduced. The law furthermore resulted in the introduction of the notice period. The second milestone in the history of Dutch EPL is seen in the post-war period, in 1945, when the Dutch government upheld a resolution that was introduced by the occupying force of Nazi Germany. This resolution imposed that an employer could not dismiss an employee without prior approval of the Labor Inspectorate: the PES route of dismissal was born. The postwar period is characterized by an increase in employee protection. Notice periods were extended and a specific issuing of rules for economic dismissals was introduced. We close Section 3 with an overview of the most recent 30 years in which the need for flexibility increased. Employers argued that EPL had become too rigid. In times of international competition, there was a need better adjust to changes in labor demand and supply.

In Section 4 we continue this chapter by placing the Dutch EPL in an international context. We use the summary measures of employment protection legislation of the OECD to compare the strictness of the Dutch labor market to the strictness of the labor markets of other OECD member countries. We show that in terms of regulation for permanent workers, the Netherlands has one of the most regulated labor markets of all.

Section 5 presents a literature review on how research on the effect of EPL on different labor market outcomes has proven inconclusive. A main argument used by policymakers and politicians is that the Dutch system does not positively affect the functioning of the labor market. We argue that the arguments used by the government are based on untested premises. This leaves room for severe debates and divides the government into opponents and advocates of a more liberal EPL. Agreements are not reached because the expected outcomes of certain proposed modifications are not testable. Section 6 concludes.

\subsection{The current Dutch EPL}

This section describes Dutch labor law as it is enforced today. It starts with a general description, followed by an overview of the rules applied by the PES and the civil court. Last, a schematic presentation of the differences between both institutes is given.

\subsubsection{Two routes of dismissal}

In the Netherlands, rules regarding the termination of employment contracts are recorded in the Civil Code $^{29}(\mathrm{CC})$, the Extraordinary Labor Relations Decree ${ }^{30}$ (ELRD), the Dismissal Decree ${ }^{31}$ (DD) and the Collective Redundancy Act ${ }^{32}$ (CRA). In cases where regulations are not compulsory, or where the law is silent, collective labor agreements may be a source of law. Dutch law makes a distinction between fixed term employment contracts, which are contracts concluded for a definite period of time and permanent employment contracts, which are contracts concluded

\footnotetext{
${ }^{29}$ In Dutch: Burgerlijk Wetboek.

${ }^{30}$ In Dutch: Buitengewoon Besluit Arbeidsverhoudingen.

${ }^{31}$ In Dutch: Ontslagbesluit.

${ }^{32}$ In Dutch: Wet Melding Collectief Ontslag.
} 
for an indefinite period of time. Fixed term contracts automatically expire at the end of a predefined period. ${ }^{33}$

Under Dutch law, employees (with a permanent employment contract) are protected against dismissal by a preventative or a-priori system of dismissal. An employer may either request: the PES for a permission of dismissal (sec. 6 ELRD); or the civil court for a dissolution of the employment contract (sec. 7:685 CC).If an employer has chosen for termination of the contract via the PES, but the PES does not grant dismissal permission, he can still request for the rescission of the contract by the civil court, and vice versa. Both institutes act independently from each other.

Other options to terminate an employment contract are at will during the trial period, termination by mutual consent, termination by operation of law ${ }^{34}$ and by summary dismissal. In these cases, the above routes do not apply.

A reason for an employer to select the PES route of dismissal is that the payment of severance is not obliged. The PES route is also the route to follow when the dismissal is of a collective nature. The civil court route is chosen because it is in general the fastest route. Furthermore, the civil court may resolve the employment contract when a dismissal prohibition exists. The choice to follow the one or the other route is a strategic choice that is dependent on the expected cost of a certain route and the likelihood of success. For one employer the PES route is the cheapest and the most effective route, for the other employer this holds true for the civil court route.

Figure 1 shows the number of requests filed at both institutes. In 1993, approximately 75 percent of all requests was directed at the PES. From 1998 to 2008, the two routes were chosen in almost equal proportions. In the year 2003, the number of dismissal requests filed reached its peak with 85,881 and 78,419 cases filed at the PES and the civil court, respectively. This number decreased until 2008 and rose again in 2009. In 2009, however, the civil court lost its popularity as almost 70 percent of all dismissal cases went via the PES route. After 2009, the PES route is followed approximately twice as often as the civil court route.

\section{Route I: Dismissal permission via the PES}

Termination of employment by dismissal via the PES is governed the Extraordinary Labor Relations Decree (ELRD) and the Dismissal Decree (DD). The ELRD and DD summarily deal with formal and material conditions for granting dismissal permission and apply to all employment contracts and cases that are covered by section 7:610 (CC). ${ }^{35}$ Section 1(b) (ELRD) expands this definition to workers who perform personal labor without a contract of employment. ${ }^{36}$ The ELRD and DD do not cover: 1) employees of a public body; 2) persons in an ecclesiastical position; 3) the teaching staff of educational institutes led by a natural person or body

\footnotetext{
${ }^{33}$ Fixed term contract may be concluded for a specific task, a project or a definite term (sec. 7:667(1) CC).

${ }^{34}$ A termination of an employment contract by operation of law may imply the expiry of a fixed term contract or the death of an employee.

${ }^{35}$ Section 7:610 (1) (CC) states that the employment contract is an agreement under which one party, the employee, is employed by the other party, the employer, in return for remuneration for a certain period of time.

${ }^{36}$ Unless a) personal labor is performed for at least three other persons, b) the employee is not assisted by at least three other persons other than the registered partner/husband/wife/family member/foster children, c) this personal labor is incidental.
} 
corporate; 4) employees only or predominantly performing domestic work in private households for less than three days a week (sec. 2 ELRD); and 5) statutory directors (Stcrt 1872, 234).

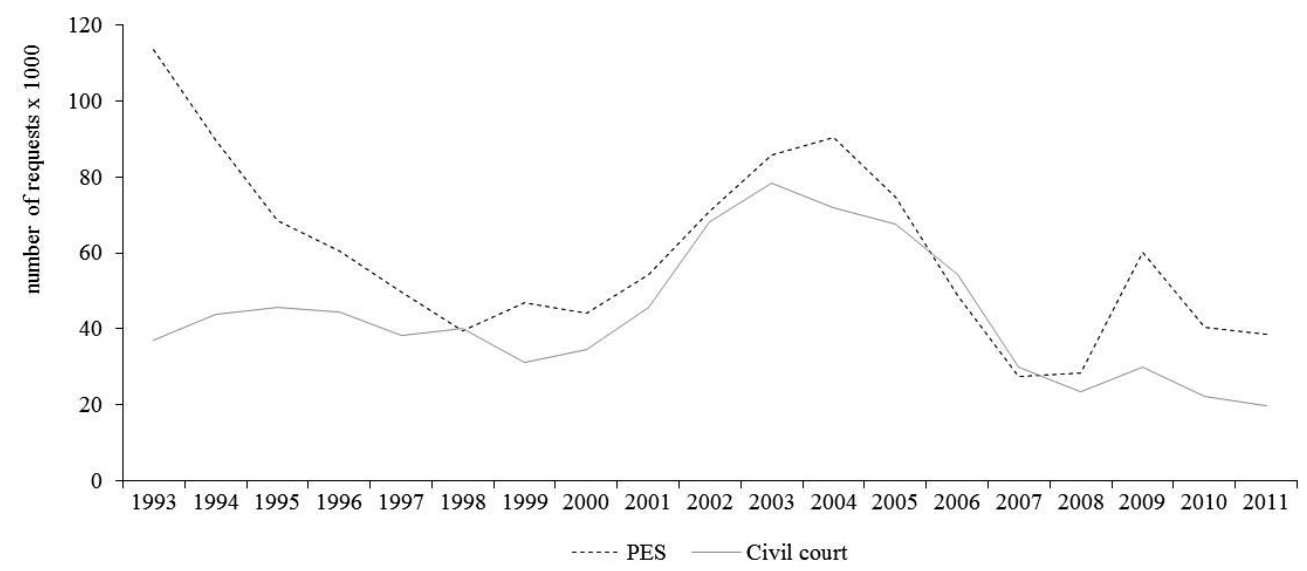

Figure 1 Dismissal requests at the PES and the civil court.

Sources: CPB 135 - Employment Protection Legislation (2006), Ontslagstatistieken, 2006-2009, Raad voor de Rechtspraak (2012), UWV (2012)

Table 1 The minimal information required in the dismissal application.

\section{Information required}

Employer related information

The name and the address of the employer

The date

An indication that the request concerns a dismissal permission

Employee related information

The name of the employee concerned

Address, postal code and place of residence of the employee

Date of birth of the employee, date first day of employment

Job description, gross wage

Social security number

Reason for termination of the contract of employment

Source: UWV (2011)

Table 2 Statutory minimum period of notice.

\begin{tabular}{lll}
\hline Tenure & Section 7:672(4) CC: approval of PES & Section 7:672(2) CC \\
\hline Less than 5 year & 1 month & 1 month \\
5 to 10 years & 1 month & 2 months \\
10 to 15 years & 2 months & 3 months \\
More than 15 years & 3 months & 4 months \\
\hline
\end{tabular}

Source: UWV (2011) 
The PES operates under close supervision of the government. The minister of Social Affairs and Employment is authorized to grant dismissal approval and has delegated this authority to the PES. The PES is supposed to report to the Minister on how the authority to grant dismissal approval is practiced. Rules governing the dismissal approval are set by the Minister (sec. 6(7) ELRD).

The dismissal procedure commences with a written application that is send by the employer to the PES. The application must contain the reason for dismissal and should be substantiated by evidence. The subsidiary of the PES that is situated in the area in which the concerned employee is employed is responsible for handling the request. ${ }^{37}$ Table 1 presents the minimum information the application is required to contain. If on receipt of the appeal information is missing, the employer has eight more days to fulfill all requirements. As soon as the PES has received a complete appeal, the involved employee is notified and given the possibility to submit a written defense within two weeks after notification (sec. 2:2 (DD)). In a next step, the dismissal file including the employer's application and the employee's defense, is send to a Redundancy Committee (sec. 6(4) ELRD, sec. 2:5 DD). This committee is composed of representatives of the workers' and the employers' associations. Its task is to advise the PES. On the basis of this advice, the PES reaches a decision. Permission is given if dismissal is judged to be fair (sec. 3:10 DD). Fair dismissals are dismissals based on economic grounds (e.g redundancy), dysfunctional behavior, a disturbed employment relationship, illness and misconduct. ${ }^{38}$ The dismissal permission is time-limited and valid for a maximum period of eight weeks. The employer is not obliged use the permission; he may also let it expire. ${ }^{39,40}$

A standard PES dismissal procedure takes four to six weeks. Complicated cases and cases in which the employer fails to provide sufficient information may take longer.

Under Dutch law, termination of an employment relationship is unlawful when the statutory notice period is not observed 7:672(2) (CC). With permission from the PES, statutory notice periods are reduced by one month (sec. 7:672(4) CC ${ }^{41}$ (See Table 2).

It is not possible to make an appeal to the decision of the PES (sec. 6(10) ELRD). The employee, however, may file a request at the civil court because of being manifestly unreasonably dismissed (sec. 7:682 CC). Civil court may compensate the employee for being unreasonably dismissed or it may recover the employment relationship.

\section{Route II: Dismissal via civil court}

Rules and regulations regarding the rescission of the employment contract by court are recorded in the Civil Code (CC). The Civil Code applies to all employment contracts and cases in which one party, the employee, is working for the other party, the employer, in return

\footnotetext{
${ }^{37}$ Multiple subsidiaries of the PES are located throughout the Netherlands, each covering a different, multiply exclusive, area. See Chapter 3 of this dissertation.

${ }^{38}$ We refer to the Dismissal Decree, section 4 and section 5 for a complete overview of all grounds for dismissal

${ }^{39}$ The PES determines the term for expiration, the maximum is eight weeks (sec. 2:7 DD).

${ }^{40}$ The PES does not terminate the employment contract. It only permits the employer to terminate the employment contract.

${ }^{41}$ In order to resign, employees need to give notice one month in advance (sec. 7:672(3) CC).
} 
remuneration for a certain period of time $7: 610$ (1) (CC). ${ }^{43,44}$ The civil court that is located in the area in which the employee lives or works is responsible for handling the request (sec. 7:685(3) $\mathrm{CC}) .{ }^{45}$ The procedure commences with a written appeal (sec. 7:685(1) CC) that is send to court and that motivates the employer's intention to terminate an employment contract. No specific rules regarding the content of the appeal exist. Shortly after, the employee concerned is notified and is given the opportunity to submit a written defense.

We can distinguish between two types of dismissal cases. The first type of case is the proforma case. It is a non-contradiction case, which implies that the outcome is mutually agreed upon by the employer and employee involved. Preceding the court procedure, agreements are made about the date of termination and the severance payment that will be awarded to the dismissed employee. The court generally follows the agreements made. As such, an oral court session in which the employer and the employee are heard is generally not held. The second type of case is the contradiction case. In these cases, employer and employee disagree about the terms of dismissal. When the civil court receives a request of the second type, both parties are heard in front of court. ${ }^{46}$ The court's decision is presented shortly after this court hearing. When the court decides to rescind the employment contract it is allowed to ignore the statutory minimum notice period as recorded in section 7:672(2) CC (See Table 2). A standard contradiction procedure takes three to four weeks. The duration of a pro-forma procedure is shorter.

The civil court will rescind an employment contract if a substantial reason exists (sec. 7:685 (2) CC). A substantial reason is a circumstance that would have also allowed for an immediate dismissal. Examples are fraud, incompetence, drunkenness, theft and reckless behavior. A substantial reason also refers to a circumstantial change that justifies the termination of an employment relationship. Examples are economic circumstances, a disturbed employment relationship and illness.

Unlike the PES, the civil court may award a severance pay (sec. 7:685(8) CC). This only holds true when the employment contract is rescinded because of a change in circumstances. In calculating the severance pay the Civil Court Formula is used as a guideline. The formula multiplies the number of years of service (A) by the gross monthly salary (B) and by a correction factor expressing the special circumstances of the case (C). The years of service up to the age of 35 are counted as half a month's salary, from 35 to 45 as 1, from 45 to 55 as 1,5 and after 55 as 2. With the correction factor, the civil court takes into account the culpability of the parties. The factor is equal to 1 if none of the parties are culpable. It is larger than 1 if mainly the employer is culpable and smaller than 1 if mainly the employee is culpable. The civil court may also take into account the financial situation of the employer and the job market position of the employee. It is not possible to make an appeal to the court's decision.

\footnotetext{
${ }^{43}$ Unless agreed-upon otherwise by both parties, before or on initiation of the employment relationship, either by law or by ordinance, the provisions of the Civil Code do not apply to persons employed by the State, the District Council, the City Council, the Water Board or any other public body (sec. 7:615 CC).

${ }^{44}$ This route of termination via judicial decision is predominantly used by employers, but employees may also follow this procedure.

${ }^{45}$ Civil courts are located throughout the Netherlands, each covering a different area, see Chapter 3.

${ }^{46}$ Section 7:685(6) (CC) stipulates that this oral session is supposed to be held within four weeks after the appeal date.
} 


\subsubsection{Prohibitions of dismissal}

In addition to the general protection against dismissal as mentioned above, special protection is provided for employees in certain situations. This protection prohibits employers to dismiss employees during the first two years of illness, during pregnancy and maternity leave and because of membership of the works council, a works council committee or a safety committee. ${ }^{47}$ If an employer contravenes a prohibition, the employee concerned may invoke the invalidity of such dismissal within a time limit of two months. In such case, the dismissal is declared annul and the employee is reemployed. If an employer intends to dismiss a worker for whom a dismissal prohibition exists, he may follow the civil court route as civil courts may dissolve a contract in the presence of such a prohibition. The reason for dismissal, however, may not be related to the dismissal prohibition. For example, the civil court will not resolve the contract of an employee that is sick for less than two years due to the fact that the employee is ill. The contract of the concerned employee can be dissolved on the basis of economic grounds.

When an employer requests for a dismissal approval of at the PES, he is notified by the PES about the existence of a prohibition of dismissal. The employer may decide to proceed with the procedure or to withdraw the request. In deciding whether or not to grant dismissal permission, the PES does not take into account the existence of a dismissal prohibition. It only checks whether the dismissal meets all the criteria of a reasonable dismissal. If all criteria are met, dismissal permission is given. The employer may decide to use the permission and dismiss the employee before it expires. Dismissal, however, even is the presence of a permit of the PES, is invalid when a dismissal prohibition exists.

\subsubsection{A schematic overview of the comparison of both routes}

Table 3 below shows a schematic summary of both routes and their characteristics. Table 4 presents a summary of the options for both the employer and the employee, after the employer has initiated a procedure via either the PES or the civil court.

\footnotetext{
${ }^{47}$ The law records more prohibitions of dismissal. For a complete over view see sec. 7:670, Civil Code of Law.
} 
Table 3 The two different routes compared.

\begin{tabular}{|c|c|c|}
\hline & PES & Civil Court \\
\hline System of a-priori control & $\begin{array}{l}\text { The permission to terminate an employment } \\
\text { contract. }\end{array}$ & $\begin{array}{l}\text { The rescission of the employment } \\
\text { contract by the judge. }\end{array}$ \\
\hline $\begin{array}{l}\text { Who can commence the } \\
\text { procedure? }\end{array}$ & The employer only. & $\begin{array}{l}\text { Both parties, although it is } \\
\text { predominantly used by the employer. }\end{array}$ \\
\hline Section of law & Section 6 ELRD. & Section 7:685 CC \\
\hline $\begin{array}{l}\text { What determines which } \\
\text { district is responsible for } \\
\text { handling the appeal? }\end{array}$ & The place of employment. & $\begin{array}{l}\text { The place of residence of the } \\
\text { employee or the place of } \\
\text { employment. }\end{array}$ \\
\hline Range & $\begin{array}{l}\text { All employees covered by section 7:610 (1) } \\
\text { (CC) with the exception of 1) employees of a } \\
\text { public body; } 2 \text { ) persons in an ecclesiastical } \\
\text { position; } 3 \text { ) the teaching staff of educational } \\
\text { institutes led by a natural person or body } \\
\text { corporate; } 4 \text { ) employees only or } \\
\text { predominantly performing domestic work in } \\
\text { private households for less than three days a } \\
\text { week (sec. } 2 \text { ELRD); and 5) statutory directors } \\
\text { (Stcrt } 1872,234 \text { ). Workers who perform } \\
\text { personal labor without a contract of } \\
\text { employment are covered. }\end{array}$ & $\begin{array}{l}\text { All employees covered by section } \\
\text { 7:610 (1) (CC) with the exception of } \\
\text { persons employed by the State, the } \\
\text { District Council, the City Council, the } \\
\text { Water Board or any other public body } \\
\text { (sec. 7:615 CC). }\end{array}$ \\
\hline Duration of procedure & $\begin{array}{l}75 \% \text { of all requests is handled within four to } \\
\text { six weeks. }\end{array}$ & $\begin{array}{l}\text { Three to four weeks in case of a } \\
\text { contradiction case. Pro-forma cases } \\
\text { can be closed within a week. }\end{array}$ \\
\hline $\begin{array}{l}\text { Statutory notice period } \\
\text { applies? }\end{array}$ & $\begin{array}{l}\text { Yes, however, after dismissal approval of the } \\
\text { PES, the applicable notice period described } \\
\text { by law may be reduced with one month, } \\
\text { provided that the notice period will not be } \\
\text { less than one month (sec. } 7: 672(4) \mathrm{CC} \text { ). }\end{array}$ & $\begin{array}{l}\text { No. The judge decides when the } \\
\text { employment contract is rescinded. }\end{array}$ \\
\hline Severance pay awarded & $\begin{array}{l}\text { The PES is not entitled to award severance } \\
\text { pay. }\end{array}$ & $\begin{array}{l}\text { Severance pay is awarded. The Civil } \\
\text { Court Formula is used as a guideline. }\end{array}$ \\
\hline Appeal possible? & No. & No. \\
\hline $\begin{array}{l}\text { Possible to dismiss an } \\
\text { employee for whom a } \\
\text { dismissal prohibition applies? }\end{array}$ & No. & $\begin{array}{l}\text { Yes, if the reason for dismissal is } \\
\text { unrelated to the reason for the } \\
\text { existence of the dismissal prohibition. }\end{array}$ \\
\hline
\end{tabular}


Table 4 Different options to follow after each dismissal procedure.

\begin{tabular}{|c|c|}
\hline Dismissal via PES & Dismissal via the civil court \\
\hline PES checks if dismissal is fair. & $\begin{array}{l}\text { Civil court checks for the existence of a substantial reason } \\
\text { to dissolve the employment relationship. }\end{array}$ \\
\hline $\begin{array}{l}\text { It is not possible to make an appeal against the decision } \\
\text { of the PES. }\end{array}$ & $\begin{array}{l}\text { It is not possible to make an appeal against the decision } \\
\text { of the civil court }\end{array}$ \\
\hline $\begin{array}{l}\text { Option employer: If dismissal permission is not granted, } \\
\text { the employer may initiate a dismissal procedure at the } \\
\text { civil court. }\end{array}$ & $\begin{array}{l}\text { Option employer: If the contract is not dissolved, the } \\
\text { employer may initiate a dismissal procedure at the PES. }\end{array}$ \\
\hline $\begin{array}{l}\text { Option employee: If dismissal permission is granted the } \\
\text { employee may file a request at the civil court because of } \\
\text { his dismissal being manifestly unreasonable. Civil court } \\
\text { may compensate the employee according to the civil } \\
\text { court formula }(A \times B \times C) \text {. }\end{array}$ & $\begin{array}{l}\text { Option employee: The employee does not have any } \\
\text { options. }\end{array}$ \\
\hline
\end{tabular}

\subsection{History of Dutch EPL ${ }^{48}$}

This section describes the history of Dutch EPL. An overview of history is important to understand the Dutch system as it exists today.

\subsubsection{The first protective measures}

\section{The introduction of the Civil Code of Law}

The introduction of the old Civil Code of Law (old CC) ${ }^{49}$ in 1838 can be regarded as a milestone in the history of Dutch EPL. Inspired by the French Code Civil of 1804, the Dutch Civil Code introduced a new national civil law. Even though the Civil Code did not encompass labor law in its strictest sense, it did contain three sections regarding the lease and letting of servants and workers. ${ }^{50}$ First, section 1637 (old CC) recorded that a person could only work for one specific organization. Second, section 1638 (old CC) stipulated that the master, under oath, should always be taken at his word in case of disputes about the amount of wage paid, the terms of payment and the length of the employment relationship. Finally, in section 1639 (old CC) it was stipulated that servants and workers, unless hired for a predetermined period, were not allowed to leave their master without a lawful reason. If, for any reason, servants or workers did leave unlawfully, they were fined.

\footnotetext{
${ }^{48}$ When writing this historical overview, main sources of information used were Naber (1981), Nyfer (2000), Heerma Van Voss (1992), Pennings (2007), CPB (2006), Loonstra and Zondag (2008) and Van Drongelen, and Van Rijs, (2008).

${ }^{49}$ In 1992 the new Civil Code of Law was introduced. It replaced the old Civil Code of Law. All articles received a new number.

${ }^{50}$ Rules and regulations regarding the employment relationship where stipulated in General Agreements Law (In Dutch: Algemene Overeenkomstenrecht).
} 
Even though these three sections might seem of marginal importance in our 21st century perspective, they were quite revolutionary at their time. Since the introduction of the Civil Code in 1838, regulations regarding the employment relationship were recorded in General Agreements Law ${ }^{51}$. This law applied the concept of contractual freedom. Before 1838 this freedom was unheard of. In the old guild system the employment relationship between the master and the apprentice was fixed: the apprentice could not just leave and work for another master. Nevertheless, it must be noted that despite of the transition from fixed employment relationships to contracts and contractual freedom, the servant remained inferior to the master. After 1838 it was still the master who determined the content of the contract. This inferiority of the servant is also evident from section 1638 described above: "under oath, the master should always be taken at his word". In modern eyes, this article seems ridiculously unfair. However, the legislator of 1838 believed that master was the most sophisticated one, not the worker. Therefore, it was 'obvious' to trust the former one at forehand.

\section{The industrial revolution}

As a result of the rise of the Industrial Revolution at the second half of the 19th century, labor conditions changed drastically. To keep the production process in factories going, many (uneducated) workers were needed and even children were put into use. Labor became concentrated around the bigger cities. Hoping for a better life, families were drawn from the countryside towards this concentration of work. Living conditions in these cities were far from pleasant. Housing was poor, the overall educational level was low and circumstances in factories were dreadful. Not occasionally, working shifts took longer than 20 hours. Furthermore, workers earned minimum wages and were often forced to spend a huge part of what they earned at the shop or factory of the employer, regularly against too high prices. In the event of death or sickness of the wage earner, families struggled to survive. Poverty care existed but was little developed.

This social unjustness led to the development of (worker) unions. In general, however, the impact of these movements was minimal. One of the few unions that did have some impact was the 'Comite ter bespreking van de sociale quaestie' (1870-1880). This committee was formed by politicians, intellectuals and members of worker unions and was concerned about the arising social unrest and the need for better conditions for workers. Especially the position of women and children was perceived as worrisome. Public awareness arose that conditions would not improve without governmental interference. Even though the government remained little involved in improving social matters, child labor was soon tackled. In 1873, the first, but still modest labor law was introduced: de Child Law Van Houten ${ }^{52}$. It arose as the consequence of a parliamentary inquiry about labor conditions in factories and workshops, held in 1866 . The law forbad paid employment of children under 12, except for domestic services and fieldwork. Sixteen years later, the Labor Law ${ }^{53}$ of 1889 stipulated the working hours of children under 16 and of women. Furthermore, the new law introduced the Labor Inspection. In that same year night shifts for women were forbidden. The Security Law ${ }^{54}$ of 1895 offered adult men some

\footnotetext{
${ }^{51}$ In Dutch: Algemene Overeenkomstenrecht.

52 In Dutch: Kinderwet Van Houten.

${ }^{53}$ In Dutch: Arbeidswet.

${ }^{54}$ In Dutch: Veiligheidswet.
} 
protection against the hazards in the industry. It imposed employers to protect their workers against health and safety danger in factories and workshops. ${ }^{55}$

\section{Law on employment contracts}

In 1907, the Law on Employment Contracts ${ }^{56}$ was passed. This law introduced the first legal measures that aimed for the protection of the employee. The institution charged with the enforcement of this protection was the civil court. The 1907 law recorded approximately 20 articles about the termination of the employment contract (articles 1639e till 1639x (old CC)). Together, these articles introduced three different options to terminate an employment contract. The first option was the termination of an employment contract by operation of law. Examples are the expiry of a fixed term contract and death of one of the two parties. The second route was the termination of the employment contract by mutual consent. The third route was the termination of the employment contract via the civil court. ${ }^{57} \mathrm{~A}$ very important article in this third route is article $1639 \mathrm{w}$, which enabled the civil court to dissolve a contract only in extraordinary circumstances. ${ }^{58}$ The possibility to award severance pay did not exist yet. After some modifications that broadened the possibilities of the civil court to dissolve an employment contract, article 1639w (old CC) would later become article 7:685 (CC), the article described in the first paragraph of this chapter and the article on which the civil court route is based.

The 1907 law was characterized by its strong emphasis on wages. Protection was found in regulations imposing the form in which the wage should be paid. For example, wages in the form of vouchers to be exchanged for goods that were sold by the employer were no longer allowed. Article 1638c recorded that the employee was entitled to receive his wage in times of sickness. Furthermore, the law regulated medical treatment for resident employees (article 1638jj (old (C)). Additionally, the new law dealt with regulations about the collective labor agreement (article 1937n (old CC)), a competition clause (article 1637w (old CC)) and stipulations imposing safety regulations within the organization (article $1638 \mathrm{x}$ (old CC)). This last article $1638 x$ obliged the employer to safeguard the working environment. If safety regulations were not met and damage occurred, the employee was entitled to receive a damage pay (Heerma van Voss, 1992; Keirse, 2003; Pennings, 2007). ${ }^{59}$ Another crucial element in the 1907 law was the introduction of the notice period. A permanent employment contract could not be terminated without notification in advance. The notice period equaled the period in between two sequential payments. The maximum was six weeks.

Even though the Law on Employment Contracts broke drastically with its past, the protection provided by the law was still minimal. In practice, the notice period never took longer than a week, regardless of the duration of employment (Naber, 1981). Furthermore, disputes between employee and employer were often not resolved. For example, workers still received their pay in an unlawful form or did not receive it in time. (Pennings, 2007). Another downturn

\footnotetext{
${ }^{55}$ In all industries except for agriculture, horticulture, forestry, cattle farms, fishing and shipping.

${ }^{56}$ In Dutch: Wet op de Arbeidsovereenkomst.

${ }^{57}$ For a more detailed description of these articles see Heerma Van Voss (1992), p35.

${ }^{58}$ Such a circumstance applied when e.g. the employer lost his fortune. Over one hundred years ago it was quite regular that employers and employees formed temporary employment relationship for e.g. three years. If an employer fired the employee after 2 years, the employer was obliged to pay the employee the remaining year loan.

${ }^{59}$ This damage pay was only received if the employee could proof the employer was to blame.
} 
of the 1907 law was that both employers and employees did not have to state a valid reason to terminate a contract, or in other words, the underlying reason for termination was irrelevant. ${ }^{60}$ Even though dismissal needed to be declared legitimate by the court - that is, consistent with the legal notice period - any check on reasonableness by the court was lacking. In most cases this was more harrowing for the employee than for the employer.

Following 1907 is a period of continuous discussion about the minimal level of employment protection. Both the lack of a reasonableness check on dismissal by the court and the minimum notice period were debated. Even though in the 1910's and 20's the rising power of labor unions led to the naissance of an additional number of collective labor agreements in which rules related to the dismissal procedure were recorded, each attempt to bring about a more protective national EPL failed. ${ }^{61}$

\subsubsection{The period during and following the Second World War}

The impact of the German occupation of 1940-1945

The core of Dutch EPL remained unaltered until the Germans enacted the First Enforcement Decision $^{62}$ on June $11^{\text {th }} 1940$. This Decision recorded a unilateral dismissal prohibition, imposing that an employer could not dismiss an employee without the approval of the Labor Inspectorate. For dismissal a reasonable cause was required. If the Labor Inspectorate judged dismissal to be unreasonable, permission to terminate the employment contract was not given. Violations of the prohibition were sanctioned with a fine of maximum $€ 3.000$ or three months of detention. As of the $1^{\text {st }}$ of March 1943 not only the employer but also the employee needed permission to terminate an employment contract. The unilateral prohibition became a bilateral prohibition.

Why did the Germans introduce the dismissal prohibition? Actually, the main purpose of the introduction of the prohibition was to regulate the labor market, the protection of employees was of minor importance. Especially the modification of the prohibition into a bilateral one was more driven by need to regulate the labor market than by socio-economic considerations. During the war many workers were needed for the war industry in the German homeland. Hence, the Germans intended to prohibit workers to resign.

\section{The Extraordinary Labor Relations Decree 1945}

In 1945, when the defeat of the Germans became apparent, the Dutch government upheld the German procedures in the Extraordinary Labor Relations Decree ${ }^{63,64}$ (ELRD). The role of the Labor Inspectorate was taken over by the Regional Employment Exchange ${ }^{65}$. (From 1991 until

\footnotetext{
${ }^{60}$ Unless summary dismissal (In Dutch: ontslag op staande voet) had occurred (Peeters, 2006).

${ }^{61}$ In the 1930's only workers in the graphical industry, in the beer breweries in the three largest cities in the Netherlands and in a few brick producing companies received special employment protection (Heerma Van Voss, 1992).

${ }^{62}$ In Dutch: Eerste Uitvaardigingsbesluit.

${ }^{63}$ In Dutch: Buitengewoon Besluit Arbeidsverhoudingen.

${ }^{64}$ The Dutch government in exile had introduced and earlier version of the Decision at July $17^{\text {th }} 1944$. Because a chosen parliament did not exist, this decision could not be checked by a parliament. As such, the ELRD is a decision that received the status of a law by Royal Decision (In Dutch: Koninklijk Besluit).

${ }^{65}$ In Dutch: Gewestelijke Arbeidsbureaus.
} 
2002 the Regional Director Labor Facilities ${ }^{66}$ was assigned to perform the check. In 2002, the Centre for Work and Income (CWI) took over. Today, as of January 2009, the PES (UWV) is responsible). For dismissal a reasonable cause was required. If the Regional Employment Exchange judged dismissal to be unreasonable, permission to terminate the employment contract was not given.

Before the introduction of the Extraordinary Labor relations Decree (ELRD), Dutch EPL was very liberal. An employer could dismiss at will, he or she only needed to take into account the notice period. When the employer had met the notification duty, the termination of the employment contract was declared legitimate. In other words, before the introduction of the ELRD no valid reason for dismissal was required. Additionally, before 1945, the civil court was the only institution enforcing employment protection. The ELRD introduced a second, public body responsible for this task.

\section{The 1953 revision of Dutch EPL}

In December 1953, Dutch EPL was revised. Due to this revision also the civil court became entitled to perform a check on the fairness of dismissal (article 1639s (old CC)). Unlike the reasonable check of the Regional Employment Exchange and the possibility of the civil court to dissolve the employment contract (article 1639w (old CC), this check was performed after dismissal had taken place. The Civil Code recorded that dismissal could not be manifestly unreasonable. Manifestly unreasonable dismissals were sanctioned with a damage pay or with the reestablishment of the employment contract (article 1639t (old CC)). Another consequence of the revision in 1953 was the prolongation of the notice period and its link to the employment duration (article 1639j (old CC)). The maximum notice period was set at a maximum of thirteen weeks, the notice period for employees between 50 and 65 was set at a minimum of three weeks. Moreover, article 1639w (old CC) was extended. This extension widened the power of the civil court to dissolve an employment contract. Dissolution was no longer restricted to extraordinary circumstances. Furthermore, the possibility to award severance pay was introduced. Last, two prohibitions of dismissal came into being: one during the first two years of sickness and one during military service. A violation of these prohibitions was sanctioned with a damage pay. ${ }^{67}$

The ELRD was introduced as an emergency plan to brave the post-war chaos on the labor market. The most important discussion following the 1953 revision concerned the role of the Director of the Regional Employment Exchange. The question arose whether he should still proceed in his task in dismissal affairs. The check on dismissal by the Director of Employment Exchange gradually gained a different character. Initially its main purpose was to regulate the labor market. A few years after the war, the protection of individuals against unreasonable dismissals had become more important. In 1953, the post war chaos on the labor market had disappeared and according to some members of parliament the ELRD had become redundant. Furthermore, since 1953 two checks on the reasonableness of dismissal existed. The first check was the check on reasonableness by the Director of the Regional Employment Exchange as recorded in the ERLD. The second check was the manifestly unreasonableness check by the civil court as recorded in article 1639s (old CC). Nonetheless, the Dutch government rejected a

\footnotetext{
${ }^{66}$ In Dutch: Regionaal Directeur voor de Arbeidsvoorziening.

${ }^{67}$ This paragraph only describes the most important and well-documented modifications of the law.
} 
motion in favor of the abolishment of article 6 ELRD with slight majority. The dual system in the Netherlands remained.

\subsubsection{After the post-war period}

\section{Prolongations of the notice period}

In 1968, the notice period was again extended. The occasion for this extension was the closure of several companies in the preceding period. Especially workers above a certain age needed better protection. As a result, the notice period for employees above 45 years was lengthened to a maximum of 26 weeks. This maximum could not be reached before the age of 58. The 1968 revision of law was in line with collective labor agreements ${ }^{68}$ of that time in which longer notice periods for older employees were recorded. In the situation of a summary dismissal the notice period does not apply (Nyfer, 2000).

\section{Wages}

Before the Second World War, the government seldom interfered in employment conditions. However, in 1945 the College of State Intermediaries ${ }^{69}$ became entitled to approve a collective labor agreement before such an agreement was enacted. In addition, the college was given the power to set binding wage agreements. The Corporation of Employment ${ }^{70}$ was closely involved. Directly after the war, interference in wage setting was generally accepted. The social partners understood that wages should be moderated in order to stimulate the reconstruction of the country. Nonetheless, a few years after 1945, the discussion arose whether the Dutch wage setting system had not become too strict. In 1953 the Social Economic Council ${ }^{71}$ pled for a more flexible system in which the social partners had more influence. However, compared to neighboring countries, which had also introduced similar systems after the war, the Dutch system survived relatively long (Pennings, 2007; Trommel, and Van der Veen, 1999 ).

With the initiation of the Law on Wage Setting ${ }^{72}$ of 1970 the existing system was modified. Two unions, the NVV and the NKV expressed huge criticism towards the new law. They even temporarily resigned from the Social Economic Council and the Corporation of Employment. ${ }^{73}$ Article 8 (old CC) was particularly criticized. Even though the law aimed for the principle of free collective negotiations, this article entitled the minister of Social Affairs to declare one or more articles in the collective labor agreements non-binding. This interference was only permitted when socio-economic interests were at stake. The unions also disapproved of article 10 (old CC), which allowed the minister to impose a wage regulation. ${ }^{74}$ On August 15th 1987, the government revised the Law on Wage Setting as a reaction to a complaint that was filed by the Dutch labor unions to the International Labor Organization (ILO). According to the labor unions, Dutch wage policy conflicted with treaties 87 and 98 of the ILO regarding the freedom to found labor unions and the right of collective negotiations. The ILO concluded that the Dutch system

\footnotetext{
${ }^{68}$ In Dutch: Collectieve Arbeidsovereenkomst.

${ }^{69}$ In Dutch: College van Rijksbemiddelaars.

${ }^{70}$ In Dutch: Stichting van de Arbeid.

${ }^{71}$ In Dutch: Sociaal Economische Raad.

72 In Dutch: Wet op de Loonvorming.

${ }^{73}$ Later, the NVV and the NKV would merge into FNV.

${ }^{74}$ Such a wage regulation could for instance impose a freeze of wages for a period of maximum six subsequent months (Trommel, Van der Veen, 1999).
} 
was indeed in force with these treaties. As a result, Article 10 (old CC) was modified to restrict the minister's possibility to interfere. ${ }^{75}$

\section{The Law Notification of Collective Dismissals}

In the situation of a dismissal due to economic reasons, a specific issuing of rules applies. Often in such situations the nature of dismissal is a collective one. The law that deals with these collective dismissals is the Law Notification of Collective Dismissals ${ }^{76}$. It was introduced in 1976 and applies when the employer intends to dismiss at least 20 employees that are working within one district of the PES within a time frame of three months. The employer has the duty to notify the PES about the collective dismissal. ${ }^{77}$ This notification duty is one of the most important elements in the law. Moreover, preceding notification, the involved labor union needs to be informed and the works council has to be consulted. Together with the notification, the employer has to request a permission of dismissal for each individual employee involved. The PES reviews these requests a month after notification (further referred to as the waiting period). During this waiting period it is examined whether political labor market measures (e.g. governmental support, retraining) could prevent unemployment on the whole or to some extent. ${ }^{78}$ In addition, a social plan is developed. The content of this plan is the result of the deliberation between the labor union, the employer and the works council ${ }^{79}$. Regulations that are recorded are e.g. redundancy schemes, measures regarding outplacement and employment mediation. The PES checks the reasonableness of dismissal.

In the situation of a collective dismissal, the Last In First Out system (LIFO-system) and the principle of reflection apply. The principle of reflection describes that dismissals should reflect the age proportions in an organization according to five age groups (15-24; 25-34; 35-44; 45-54; 55-64). Within these five age categories the LIFO-system is applied. A consequence of the LIFO system is that employees with the shortest employment duration are the first ones to be dismissed. If an employer does not properly fulfill the notification duty, the PES will not take into account the dismissal request.

\section{Prolongations of prohibitions of dismissal}

As mention previously, the first prohibitions of dismissal were recorded in 1953. After 1953, these prohibitions were prolonged. In 1976, prohibitions of dismissal for pregnant women, during maternity leave and during the first six weeks after work is resumed are recorded in the Civil Code. In that same year, a violation of a prohibition of dismissal is sanctioned with nullity (Nyfer, 2000). Initially, such violation was a sanctioned with a damage pay. In 1999, new prohibitions of dismissal are introduced for parental leave and performing worker union activities.

\footnotetext{
${ }^{75}$ Interference became allowed only in emergency situations (Van der Heijden, 1998).

${ }^{76}$ In Dutch: Wet Melding Collectief Ontslag.

${ }^{77}$ The employer needs to supply the PES with the following information: the motivation of dismissal; the number of employees that is dismissed, divided into function, age and gender; the date of dismissal; the criteria for dismissal; whether the works council is consulted and; if applicable, a report of the redundancy scheme.

${ }^{78}$ This waiting period does not hold when a declaration is submitted in which all concerned involved parties declare that they have been notified and that they agree with the situation.

${ }^{79}$ The work council is not always involved in constructing the social plan.
} 


\section{Equal treatment males and females}

Regulations in the Netherlands regarding the equal treatment of men and women are to a large extent based upon an equality program of the European Community that was initiated in 1974. This program included several directives on the equal treatment of males and females. In 1975, the Netherlands introduced the Law on Equal Remuneration of Males and Females ${ }^{80}$.

In connection with the Guideline of the Council of the European Community ${ }^{81}$ of 19 February 1976 concerning the equal treatment of men and women in labor market access, promotion and employment conditions, the Social Economic Council was requested to revise all Dutch legal regulations that might endanger the equal treatment of males and females in the job process. These regulations were originally recorded to protect female employees but had become outdated either due to technological or social developments. Following the Council's advice, the Law Equal Treatment of Males and Females ${ }^{82}$ became effective the $1^{\text {st }}$ of March 1980. In 1986, the Law on Equal Remuneration of Males and Females of 1975 was repealed. Its regulations became classed under the Law Equal Treatment of Males and Females.

In September 1994, the General Law Equal Treatment ${ }^{83}$ is enacted. This law forbids discrimination on the basis of religion, conviction, political opinions, race, gender, nationality, sexuality or martial state (Grinten, van der, 2005).

\subsubsection{The liberalization of Dutch EPL}

\section{Act on Flexibility and Security}

Since 1907, Dutch employees received more and more legal protection due to EPL. One might argue this to be a positive development. Over the years, however, the EPL system received more and more criticism. As argued, Dutch EPL had become too rigid. In times of international competition, employers needed more flexibility to dismiss their employees or to give them different tasks.

As a result of the discussion on flexibility, the Act on Flexibility and Security ${ }^{84}$ came into force in January $1999 .{ }^{85}$ This law was introduced to increase flexibility for employers and to increase security for workers with a fixed term contract. Among other things, this law enabled employers to offer the employee three successive fixed term contracts without the interference of the PES or the court. Before the introduction of the 1999 law, a fixed term contract could only be extended once. On the other hand, the law strengthened the legal position of temporary workers because after more than 3 successive contracts, or 36 months (intervals of less than three months included) these workers are supposed to be offered a permanent contract. It must be noted, however, that such a permanent contract is not always offered. As Delsen $(2002$, p63) describes: "As employers can react in different ways, the effect of the 'flexicurity' act is

\footnotetext{
${ }^{80}$ In Dutch: Wet Gelijk Loon voor Mannen en Vrouwen.

${ }^{81}$ In Dutch: Richtlijn van de Raad van de Europese Gemeenschap.

${ }^{82}$ In Dutch: Wet Gelijke Behandeling van Mannen en Vrouwen.

${ }^{83}$ In Dutch: Algemene Wet Gelijke Behandeling.

${ }^{84}$ In Dutch: Wet Flexibiliteit en Zekerheid.

${ }^{85}$ An important milestone in the discussion on flexibility was the memorandum of Minister Ad Melkert in December 1995. In this note, the minister expressed the need for greater flexibility and to improve the position of temporary workers. The Corporation of Employment was asked for advice on this matter and proposed that there should be more possibilities to extent a temporary contract. Furthermore, the corporation proposed to improve the position of temporary employees. The cabinet agreed and the Act on flexibility and security was enacted.
} 
uncertain. Either the temporary employee is hired for an indefinite period of time or the employer starts looking for another temporary employee or another way to recruit flexible personnel."

Since 1999, EPL for employees with permanent contracts is also modified. The main purpose of this modification was to shorten the duration of the PES procedure. As such, the maximum notice period is shortened to 4 months. ${ }^{86}$

The Commission Dual Employment Protection (Commission Rood).

Since 1953, the Dutch employment protection system survived repeated attempts of modification. In 1999, the Commission Dual Employment Protection (also known as the 'Commission Rood') was installed. Under the leadership of Prof. M.G. Rood, the commission's purpose was to investigate the cohesiveness of the two dismissal procedures and to consult whether or not this system should remain intact. Furthermore, the commission intended to investigate whether certain dismissal procedures could be made more transparent and better connected to the labor market. In the report, which was presented in November 2000, the commission argued for the abolishment of the preventative dismissal procedure and for the introduction of a civil repressive dismissal system. ${ }^{87}$ Together with this abolishment, the dual protection system would disappear. In July 2003, after a long period of deliberation, the Cooperation of Labor ${ }^{88}$ rejected the proposal of the Commission Rood. ${ }^{89}$ The recommendations of the commission were not put into practice. Herewith, however, the discussion about Dutch EPL would not come to an end.

\section{Commission Labor Participation}

The Participation Top Meeting ${ }^{90}$ of June 272007 was organized to elaborate on the issue of labor participation. One of the most important subjects of this meeting was the liberalization of EPL in the Netherlands. In a request for advice, dated July 3 2007, Minister Donner notifies the Corporation of Labor ${ }^{91}$ about the plans for liberalization. At the first page of this document the Minister describes the measures that are needed to increase labor participation; an improvement of EPL is amongst those measures. Furthermore, the current EPL and its different routes of dismissal is characterized as badly organized. As a result, dismissal procedures have become complex, long and expensive. According to the Minister, this complicated employment protection system inhibits employers from employing new employees. Furthermore, the relatively high costs and burdens of Dutch EPL do not positively affect the functioning of the labor market (AV/IR/2007/23064, p2). The cabinet is in favor of a simplification of the Dutch system. One of the most important suggestions made is that prior approval from the PES and the civil court is not needed. Without prior approval, however, a damage pay for the dismissed employee is made obligatory. When dismissal is due to economic grounds, the employer is relieved from the obligation to award the employee a damage pay, but only when the PES has

\footnotetext{
${ }^{86}$ As a result of the 1968 prolongation of the notice period this maximum used to be 6 months.

${ }^{87}$ See Commissie Duaal Ontslagstelsel, "Afscheid van het duale ontslagrecht" Den Haag; november 2000

${ }^{88}$ In Dutch: Stichting van de Arbeid.

${ }^{89}$ See Stichting van de Arbeid, Advies inzake het rapport van de adviescommissie duaal ontslagstelsel, Den Haag 2003, 7/03.

${ }^{90}$ In Dutch: Participatietop.

${ }^{91}$ In Dutch: Stichting van de Arbeid.
} 
granted a priori approval. At the 30th of August the Corporation of Labor delivers its advice. Employers agree to a great extent with the intentions of the cabinet. Employees are strictly against. Despite of much critique received, during the CDA conference at the 10th of November 2007 Minister Donner indicates to carry though the quest for liberalization (www.nrc.nl). ${ }^{92}$

This political impasse led to the establishment of the Commission Labor Participation ${ }^{93}$ in December 2007. This Commission is requested to investigate which measures are needed to structurally increase labor participation in the Netherlands to a level of $80 \%$ in 2016 . The report, which is delivered in June 2008, does not give a concrete advice about the modification of EPL. The commission mainly focuses on which (work related) measures have to be taken in order to bear the costs of the aging population. Liberalization of the employment protection system is hardly touched upon. After the delivery of the report the discussion on EPL seems to have come to an end. The reason why is not clear to outsiders. ${ }^{94}$

In October 2008, the cabinet, employers and FNV reach an agreement about the maximum dismissal compensation. Employees earning more than $€ 75,000$ gross per year receive maximum one yearly salary when dismissed. In exchange for this modification, the current cabinet has promised to leave employment protection untouched until the end of its period of governance (www.nos.nl). Is this the end of the long debate?

\section{New developments}

After a relatively long period of minimal discussion about Dutch EPL and the installation of a new cabinet, a new law to modify Dutch EPL was proposed in July $2011 .^{95}$ This proposal is closely related to the proposal made in 2007 by Minister Donner. The new proposal states that prior approval of the PES or the civil court is not needed. If employees do not agree with being dismissed they may file a lawsuit against their employer at the civil court, which may decide for the reestablishment of the employment contract or for a damage pay that is awarded to the dismissed employee.

In the Spring Agreement ${ }^{96}$ of May 2012, it is stated that Dutch EPL will be drastically revised in 2014. The new proposal follows the trend that was set by Minister Donner in 2007. It states that the a-priori check of dismissal of the PES and the civil court for permanent workers is abolished. Instead, a hearing procedure at the place of employment is introduced. After being dismissed, employees may reject against the dismissal at the civil court. Severance payments are set to a maximum of 6 months and may only be spend for schooling- and work-to-work projects.

One month has passed and the new proposal to modify the Dutch EPL has already received a considerable amount of criticism. In a letter to the Upper Chamber, a delegation of 16 scientists express their concerns about the new proposed EPL system. ${ }^{97}$ According to the delegation, a more flexible EPL will not necessarily lead to a more competitive economy. They argue that when labor becomes cheaper employers will be less willing to invest in innovation

\footnotetext{
${ }^{92}$ See also Van Drongelen and Van Rijs (2008).

${ }^{93}$ In Dutch: Commissie Arbeidsparticipatie.

${ }^{94}$ See for instance Jan Hensius "Schaf preventieve toets ontslag af." Het Financieele Dagblad, 3 juli 2008.

${ }^{95}$ The proposal was made by Fatma Koser Kaya, member of the political party Democrats 66 (D66).

${ }^{96}$ In Dutch: Lenteakkoord.

${ }^{97}$ For a more detailed description of this criticism see Chapter 7 of this dissertation.
} 
and training. ${ }^{98}$ Furthermore, the assumption that the proposed modification will increase job security is rejected as underprivileged, as low skilled insider are more likely to be fired and replaced by more flexible workers.

Meanwhile, (outgoing) Minster Kamp has drafted a new proposal that is related to proposal of the Spring Agreement. It is not unlikely, however, that the newly elected government will introduce its own vision on how to modify Dutch $\mathrm{EPL}^{99}$.

\subsection{Dutch EPL in an international perspective}

This section describes how the Netherlands performs internationally. How unique is our dual system actually? Can our EPL system be characterized as fairly rigid, or is the Dutch dismissal procedure amongst the most flexible ones?

\subsubsection{Uniqueness of the system}

The Dutch dual system, with its two routes of dismissal, is unique in the world. Some countries, however, do apply a preventative check of dismissal. In Germany for instance, the preventative check is executed by the works council (Betriebsrat) and not by a governmental institution such as the PES. This works council is supposed to object to the dismissal within seven days after the intention of dismissal is made known. The deadline is three days when dismissal due to urgent reasons is intended. If the deadline is not met, it is automatically assumed that the council agrees with the termination of the employment contract. Accompanied with a valid objection, the employee can request for (re)employment. Companies that employ less than five workers are not requested to have a works council at one's disposal. In such circumstances the preventative check is not executed. In Belgium the request for dismissal is not checked in advance. However, for some 'special employees' ${ }^{100}$ exceptional regulation exist and the preventative check is applied. In France, the preventive check of dismissal was performed until two decades ago. As from the Second World War dismissal was possible with the permission of the Directeur départemental du travail. If permission was not given, the employer could appeal to the Labor Inspectorate. A final appeal could be made to the federal government. The preventative check is abolished in 1986. Ever since, France is only applying the repressive check (Nyfer, 2000).

\subsubsection{The EPL index}

After publication of the studies "Regulation or deregulation of the labour market. Policy regimes for the recruitment and dismissal of employees in industrialized countries" of Michael Emerson (1988), "Job security provisions and employment" of Ed Lazear (1990), and "Job security, employment and wages" of Guiseppe Bertola (1990) policymakers became widely interested in examining the effect of EPL on labor market outcomes. In order to achieve this task, a measure of the strictness of EPL became crucial. Updating the work of Grubb and Wells (1993), the OECD

\footnotetext{
${ }^{98}$ In their argument they refer to Naastepad and Storm (2012), Vergeer and Kleinknecht (2010) and Dekker and Kleinknecht (2008).

${ }^{99}$ A general election was held in September 2012, resulting in a new government. In Chapter 8 of this dissertation we present a short update of the new plans of this newly elected government.

${ }^{100}$ Members of the works council or of a safety commission (Heerma Van Voss, 2006).
} 
has made itself responsible for accomplishing this task by calculating the OECD Employment Protection Legislation Index (EPL-index) for a large number of its member states since the late 90's. Summarized, the overall EPL index is composed out of three components. One component is related to the protection of employees with a regular contract against individual dismissal. It incorporates the i)difficulty of dismissal, which relates to the legal conditions under which dismissal is characterized to be "fair". It furthermore quantifies the ii)procedural inconveniences of the dismissal process and iii)notice and severance payments. A second component is related to specific regulations regarding collective dismissals. It only quantifies the cost which go beyond the costs that are applicable to individual dismissals. A third component captures the regulations dealing with temporary forms of work. This component measures the restrictions on using flexible forms of work. It incorporates the type of work allowed and the duration of the fixed term contracts. It also includes rules regarding temporary work agencies and requirements for agency workers to receive an equal salary and/or conditions as workers in the user firm. The constructed index intends to describe the costs of dismissal from an employer's perspective. Higher costs are interpreted as less flexible EPL.

Figure 2 shows the latest version (version 3, 2008) (101 $^{10}$ the overall EPL index for all OECD member states. The overall EPL scores range from 0.85 for the United States - completely on the right hand side of the axis - to 3.46 for Turkey, which is situated on the left hand side extreme. The Netherlands has a score of 2.23 and finds itself just left from the middle and has an almost similar score as the OECD average of 2.24. Figure 3 presents the separate component related to regular working contracts of the total EPL. It shows that the Netherlands has very stringent EPL for regular or permanent work. With a score of 2.73 the Netherlands exceeds the OECD average of 2.15. The country with the most stringent EPL for regular workers is Portugal, the least stringent is the United States. Figure 4 shows the component related to collective dismissals. With a score of 3 , the Netherlands exceeds the OECD average of 2.85. This score of 3 positions the Netherland directly next to the United Stated, the United Kingdom, Slovenia, Norway and Hungary, which all score a 2.88. Italy scores the highest, Chile the lowest. With respect to temporary forms of work the Netherlands is relatively flexible. Figure 5 shows that the Dutch score of 1.42 is well below the OECD average of 2.08. Canada is the most flexible country when it comes to temporary forms of work, Turkey is the most stringent.

\footnotetext{
${ }^{101}$ Version 3 of the overall EPL index is constructed as follows: 5/12 $x$ component regarding the protection of regular workers $+5 / 12 \times$ component regarding the protection of flexible workers $+2 / 12 x$ collective dismissal component. It is available for 30 OECD member countries and 10 emerging economies for 2008.

See www.oecd.org/employment/protection for a detailed description of the methodology.
} 


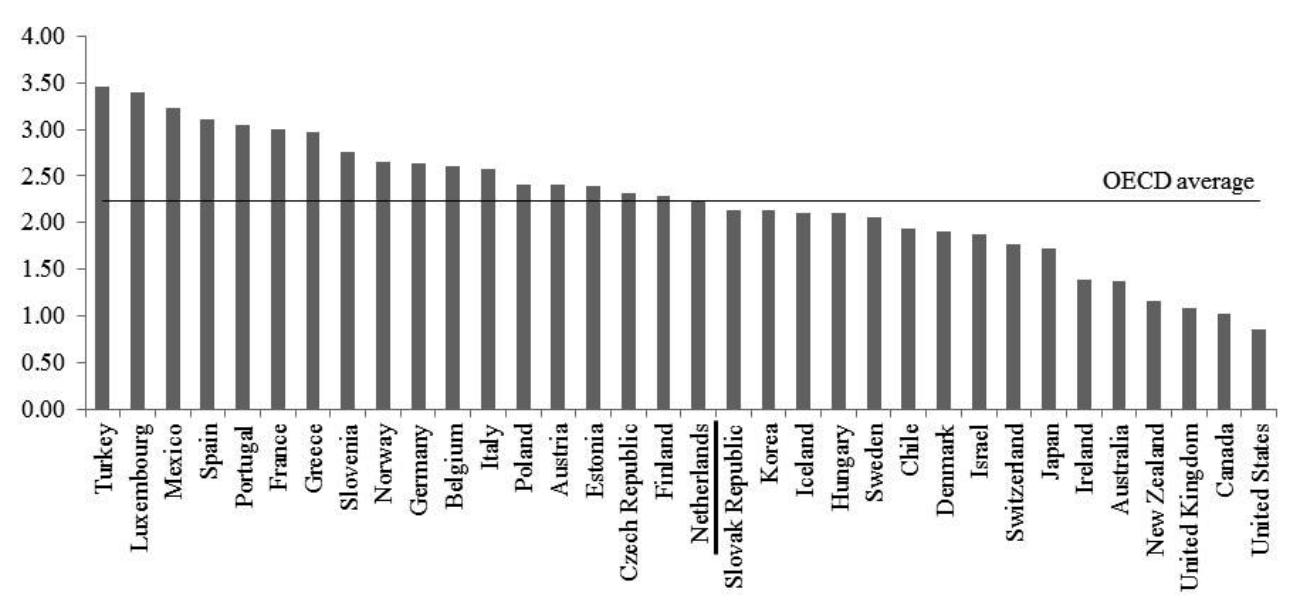

Figure 2 The overall OECD EPL index, 2008, version 3. Scale from 0 (least stringent) to 6 (most stringent). Data extracted on June 202012 15:34 UTC (GMT) from OECD.Stat

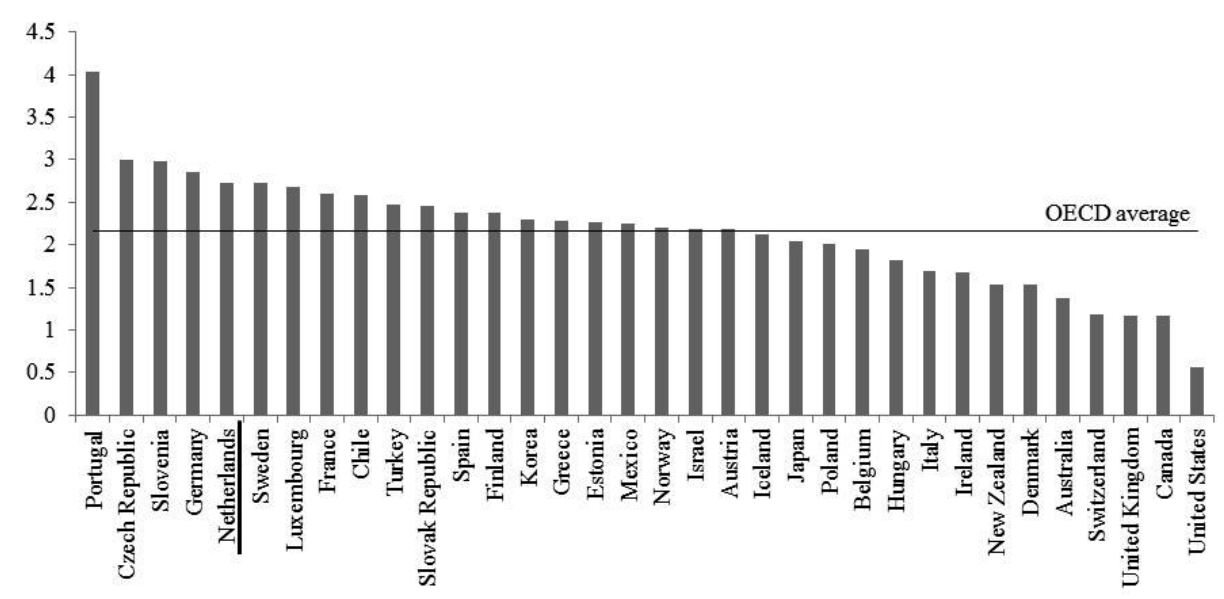

Figure 3 Component for regular workers, 2008, version 3. Scale from 0 (least stringent) to 6 (most stringent). Data extracted on June 202012 15:34 UTC (GMT) from OECD.Stat 




Figure 4 Component for collective dismissals, 2008, version 3. Scale from 0 (least stringent) to 6 (most stringent). Data extracted on June 202012 15:34 UTC (GMT) from OECD.Stat

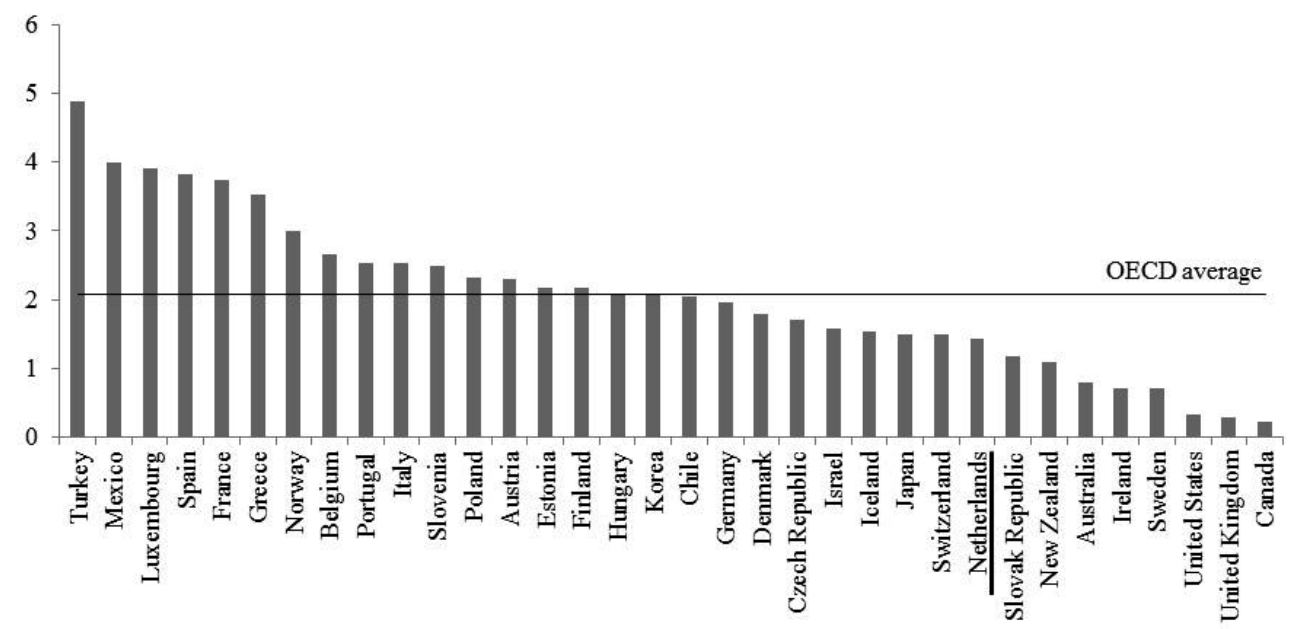

Figure 5 Component for temporary work, 2008, version 3. Scale from 0 (least stringent) to 6 (most stringent). Data extracted on June 202012 15:34 UTC (GMT) from OECD.Stat

\subsection{Discussion}

Regarding the liberalization of EPL, a general discord exists between employees and employers. Employers are in favor of a decrease in firing costs and promise to adopt more flexible hiring policies if the government decides to enact the proposed modification. Worker unions would rather increase the responsibilities of the employer and view the abolishment of the third-party check as unacceptable. Moreover, the political parties cannot reach an agreement. In December 2007, the political impasse almost led to the fall of the cabinet. 
A huge part of the problem is created by the fact that we do not know whether the relatively high firing costs of the current Dutch dismissal system lead to a decrease, or to an increase in productivity and employment. Empirical research on the effect of EPL on employment, participation and productivity has proven inconclusive. When reviewing the literature overviews of Addison and Teixeira (2003) and the OECD (2004) one can clearly see how many different conclusions are drawn. Reasons for divergence in results are differences in EPL measures across studies. Moreover, methodologies used are not the same.

In line with the general idea that EPL negatively affects the functioning the labor market, there exists a wide range of empirical studies that report a negative effect of EPL on employment (Lazear, 1990; Grubb and Wells, 1993) and labor turnover (Nickell, 1997; GomezSalvador, Messina and Vallanti (2004)). Additionally, empirical evidence exists that the effect of EPL is different for different subgroups. Nickell (1997) finds a negative relation between overall labor supply and EPL, but does not find this relation for males between 25 and 45 . Scarpetta (1996) finds a larger effect of EPL on unemployment for young workers than for the overall population. An analysis of the OECD (2004) indicates that EPL significantly reduces the employment rate of prime-age women, but not of prime-age men. In addition, some research suggest that the effect of EPL cannot be analyzed in isolation, as it may be influenced by the characteristics of other institutions existing in a country (Belot and Van Ours, 2004). Other studies do not find a clear effect of EPL on employment and unemployment (e.g. Addison, Teixeira and Grosso, 2000).

The above mentioned studies are all macro-studies that exploit cross-country variations to identify the effect of EPL on specific labor market outcomes. A main problem with most macroeconomic studies is that they rely on a limited short time series for OECD countries and fail to provide evidence on the robustness of their results. An additional challenge that emerges is to prove causality. Does a significant correlation between EPL and employment imply a direct effect of EPL on employment or may we not draw this conclusion? Another possibility is that countries modify their EPL as a result of high unemployment. Micro studies that exploit withincountry variations are a more reliable source for understanding the effect of EPL, but are rare in academic literature. Acemoglu and Angrist (2001) use a reference group to show that specific protection legislation for disabled workers in the United States negatively impacts the hiring probabilities of disabled workers. Autor, Donohue III and Schwab (2006) exploit cross-state variation in the enforcement of the employment-at-will doctrine in the United States to show that one wrongful-discharge doctrine reduced state employment rates by $0.8 \%$ to $1.7 \%$. In a European context, Bauer, Bender and Bonin (2007) estimate the effect of German employment protection on worker flows. The authors exploit the fact that smaller firms were exempt from employment protection in certain time periods. No significant effects on worker flows were found. Similarly, Boeri and Jimeno (2005) exploit the fact that firms in Italy below a certain sizethreshold are not covered by the most restrictive EPL provisions. They find that employees with permanent contracts in firms exposed to less restrictive EPL are more likely to be fired.

In a Dutch study, Pfann (2006) uses personnel files from Fokker Aircraft Manufactures to show that workers who are the least costly to fire face the weakest employment protection in a firm. In an earlier study, Pfann and Verspagen (1989) collected data from annual reports of Dutch manufacturing firms for the period 1978-1986 to relate costs of firing and hiring to the rate of workforce adjustments. Pfann and Verhagen find that when hirings exceed firings, 
employment levels will be lagged more behind the target level of employment than when firings exceed hirings.

What we do know is that the Netherlands, when compared to the other 14 of all EU15 countries, shows the lowest unemployment level, the highest labor market participation and the highest growth rate in employment. Moreover, worker productivity exceeds the European average. Despite the rigid labor market for permanent workers we do not perform poorly after all. We describe these findings in more detail in Chapter 5 of this dissertation.

\subsection{Conclusion}

In this chapter we present an overview of the current Dutch EPL, which is characterized by a preventative check of dismissal and the existence of two institutes responsible for the enforcement of labor law. In practice, this implies that, when intending to dismiss a worker with a permanent contract, an employer has two options. One option is to ask the public employment service (PES) for dismissal permission, the other option is to request the universal civil court for a dismissal permission. Both institutes apply a different set of laws and have different objectives. In an historical overview we present the most important modifications in Dutch employment protection from 1838 until today. Milestones in history are the introduction of the Dutch Civil Code in 1838, the enactment of the Law on Unemployment Contracts of 1907 and origin of the Dutch 'dual' system in 1945. Over time several attempts were made to abolish the dual system. The high costs of dismissal, the two routes of dismissal and the procedural inconveniences are the central themes in the most recent discussions on the Dutch EPL.

Seen from an international perspective, the Dutch dual EPL is unique. No other country in the world applies a similar system. In terms of the overall strictness of EPL, the Dutch labor market is an average performer. The very rigid EPL with respect to workers with a permanent contract is offset by the relatively liberal regulations regarding temporary forms of work.

Often heard in the political arena is the argument that the relatively rigid EPL for workers with a permanent contract does not positively affect the functioning of the labor market. A more liberal and cheaper system - without 'duality' - should increase flexibility in hiring and firing. We argue that the arguments used by the cabinet are based on untested premises. The government is not per se right as in-depth knowledge on the effect of labor market liberalization is lacking. We argue that too strong emphasis is placed on the modification of EPL as a medicine that will stimulate economic recovery. Political parties focus on short-term effects and are driven by sentiment. A modification of Dutch EPL should be based on a solid scientific foundation, not on cross-country comparisons such as the one conducted by the OECD. We propose an outlook for further research that uses micro-data in the line of Pfann (2006) to predict the effect of a proposed modification and to provide insight into the decision making process behind each individual dismissal case. Without such knowledge, it is impossible to forecast whether a modification of EPL will have desired effects. 

CHAPTER 3:

DATA COLLECTION 


\subsection{Introduction}

In Chapter 2, we have seen that the Netherlands applies relatively strict regulations in terms of the protection of regular workers with a permanent contract. Measured by the OECD's EPL employment protection (EPL) ${ }^{102}$ index of 2008, only Portugal, Czech Republic, Slovenia and Germany have more stringent dismissal regulations for workers with permanent contracts. Moreover, we have concluded that the Dutch dual dismissal system is unique in the world. We furthermore explained that unlike in most OECD countries, the Netherlands applies a preventative check for dismissal. This preventative check entails that Dutch employers may dismiss a worker by either requesting prior permission from the public employment service $(P E S)^{103}$, a public administrative body, or by requesting the civil court to dissolve the employment contract. According to the Dutch former Minister of Social Affairs and Employment Piet Hein Donner, the existence of two institutes enforcing labor law has created an unnecessary stringent labor market in which high firing costs and overly complex dismissal procedures discourage employers from hiring and firing (AV/IR/2007/23064). With the intention of creating a less rigid employment EPL, different governments over time have proposed to simplify the Dutch system by abolishing the dual system. The latest attempt is made in 2012 . None have caused a fundamental change to the system thus far. ${ }^{104}$

Before introducing a new system it is important to gain a deeper understanding of the system as it exists today. The PES route and the civil court route are of equal importance in the termination of a permanent employment contract, in the sense that both institutes handle an approximately equal number of request per year. ${ }^{105}$ We do not know the specifics behind the choice between the PES route or the civil court route. What type of employer follows the civil court route? Who will request for a dismissal permission via the PES? What type of employees are involved? What are the reasons for dismissal that prevail in both routes? Academic nor popular literature provides us with answers to these questions. Furthermore, the Dutch dual system is unique. The advantages of the unique aspects of the Dutch system are not examined in literature nor mentioned in the political debate about the modification of the Dutch labor market. Another question that is left unanswered is: What are the current costs for both routes? Although the studies of Hassink, Reitsma and Roorda (1998) and Knegt and Tros (2007) calculate these costs, these studies are outdated and costs are only available for the average worker. ${ }^{106}$ Moreover, both studies are based on self-reported measures.

Knowledge about the specifics behind both routes will help us to gain more insight into the working of the Dutch labor market. In order to gain this knowledge, dismissal case specific

\footnotetext{
${ }^{102}$ In this chapter we use EPL as an acronym for employment protection legislation.

${ }^{103}$ PES is used an acronym for public employment service. The official Dutch name for the PES is Uitvoerings Instituut Werknemersverzekering (UWV). In this dissertation, if we refer to the PES, we mean the UWV, and in particular the legal department of UWV that is responsible for handling dismissal requests.

${ }^{104}$ For a more detailed description of the different attempts to modify the system we refer to Chapter 2 of this dissertation.

${ }^{105}$ With the exception of the years after 2008.

${ }^{106}$ Hassink et al. used data gathered with the AVO-questionnaire (Arbeidsvoorwaarden Onderzoek), which contains information on the tenure, age and salary of a sample of Dutch workers. Using this information and estimated averages of procedural costs and the length of the procedure at both procedures, average dismissal costs for both procedures are calculated. Actual costs via the civil court and the PES are, however, not observed. The same holds true for the research conducted by Knegt and Tros.
} 
information is crucial. After an extensive search, we however realized that this information is not easily accessible. The civil court keeps track of the number of dismissal cases filed each year, but detailed case information is lacking. The PES, on the other hand, electronically stores most, but not all employee - and employer specific information of a case. Hence, we collected the data ourselves. This chapter describes how we manually collected data from 4,071 hard copy files that document the specifics of a dismissal case at PES or civil court. First, Section 2 describes how both institutes store their data. The civil court and the PES have multiple subsidiaries in the Netherlands. Only the Maastricht district is selected to be included in our dataset. Section 3 explains the logic behind this choice. Section 4 describes our sampling method. Section 5 presents an overview of the variables collected. It furthermore describes the sample in terms of missing variables. Last, conclusions are drawn.

\subsection{Data storage at both institutes}

\subsubsection{Data storage at the PES.}

For each dismissal request, case specific information is recorded in an Automation of Reports and Consolidated Orders System (ARCOS) data base. This is done by an advisory expert, responsible for handling that specific request. Table 1 lists the information the database holds. As seen in Table 1, the national database of PES does not contain information about the salary of the employee and the number of working hours per week. This information is kept in hardcopy dismissal files that are stored in a national archive located in Almere. More specifically, this information is found in the written defense of the employee. ${ }^{107}$ Next to the defense, each hard copy dismissal file contains a letter in which the employer requests for termination of an employment contract and a form stipulating the decision of the PES. The national archive at which the files are kept is an independent operator providing its services to different institutes in the Netherlands. At the time of our data gathering dismissal files for the years 2006 to 2009 were kept in the archive and were accessible. Dismissal files before 2006 were inaccessible and the year 2010 had not finished yet.

\subsubsection{Data storage at civil court.}

Data on each individual dismissal case filed between 1997 and today is stored in a national database. This database allows the civil court to keep track of the number of dismissal cases filed each year. It does not contain any detailed information on the contents of a case. Detailed information is stored in a paper folder containing a written appeal, a written defense and the judge's disposal. The appeal, which is written by a law firm operating under contract of the involved employer, contains a concise description of the reason for dismissal and some employee related characteristics such as job tenure, position, date of birth and wage. The employee's defense, as a reaction to the appeal, contains a concise description of objections to the dismissal. It furthermore states the amount of severance pay demanded in case that dismissal is inevitable. Additionally, employee and employer related characteristics are given.

\footnotetext{
${ }^{107}$ As soon as the PES has received a complete appeal notifying the PES about an employer's intention to terminate a contract of employment with one or more of his employees, the employee about whom it is concerned is notified and given to possibility to submit a written defense. This written defense is of a standard format.
} 
The judge's verdict is recorded in the disposal. The disposal furthermore contains a description of the date of termination of the contract and of the severance pay that is due. Shortly after a case is closed the hardcopy file is moved to the archive and kept there for more than twenty five years.

Table 1 Information stored in ARCOS. Only the variables relevant to our study are listed.

\begin{tabular}{ll}
\hline Variable & Remark \\
\hline Region & Identification of District \\
File system number & ARCOS assigns a unique number to each case \\
Follow up number & $\begin{array}{l}\text { In case of collective dismissal, each individual within a case receives a } \\
\text { unique follow up number }\end{array}$ \\
Collective dismissal & This variable indicates whether dismissal is part of a collective dismissal. \\
Name employee & \\
Date of birth employee & \\
Age employee & \\
Gender employee & \\
Date of first day of employment & SBI code \\
Name employer & In categories: $<10,10-100$ and $>100$ \\
Industry employer & The duration of the procedure \\
Size employer & Yes or no or withdrawn \\
Duration & The reason of dismissal \\
Dismissal granted & \\
Reason &
\end{tabular}

Source: UWV (2009)

Being allowed access to the data of PES and the civil court and to gather the data was not an easy task. First of all, because of the privacy rights of both employers and employees involved in these cases, allowing a researcher access to these files is more the exception than the rule. Another issue is that the data is only partly digitalized. As mentioned above, the civil court digitalizes none of its dismissal cases, the PES does this partly. As a consequence, a dataset is collected by scanning and reading parts of more than 4,000 dismissal files and storing the information retrieved electronically. With respect to the civil court data, all variables are collected manually. With respect to the PES data, information about (amongst others) the wage and working hours per week is merged to the national PES database via the unique file system number of a case.

\subsection{Selection of districts}

Both the PES and the civil court operate on a national level and have different subsidiaries at several locations in the Netherlands. The PES is subdivided into 11 different districts, distributed among the 6 jurisdictions North, East, North-West, Mid-West, South-West and South-East (Table 
2). ${ }^{108}$ There are 19 civil court districts. These 19 districts are distributed among the 5 jurisdictions Leeuwarden, Arnhem, Amsterdam, The Hague and Den Bosch. Each district has multiple civil courts. For instance, district Groningen has courts located in Groningen and Winschoten. District The Hague has courts located in Den Haag, Delft, Leiden, Gouda and Alphen aan de Rijn (Table 3).

We are interested in the drivers behind the decision of employers to follow either the civil court route or the PES route. We moreover want to compare the costs of both routes. The cost of a particular route is dependent upon several characteristics such as the reason for dismissal, the amount of severance pay due and the length of the period of notice. In order to avoid regional differences in these costs a selection of civil courts and PES locations that cover similar municipalities is a necessary condition. This necessary condition of complete overlap holds for the Netherlands in total. However, as mentioned before, the civil court does not store specific case information in a database. The information is kept, but recorded in hard copy dismissal files that are stored in regional archives. Collecting data on a nationwide scale implies visiting all 19 civil court districts with courts located at 56 locations spread all over the Netherlands. ${ }^{109}$ In terms of time and costs available this is not a feasible option.

Employers are not free to decide to file a request at any civil court or PES district. The PES in the district in which the employee works is responsible for handling the request. For a civil court to be responsible, an employee should live or work in the district of that respective civil court. ${ }^{110}$ In other words, when deciding to select a civil court or a PES location an employer is constrained by the region in which he is located. To give an example, an employer being located in Maastricht and employing a worker that lives in Simpelveld, a small town close to the city of Maastricht, can only file a request at the civil court in Maastricht or at the PES in Maastricht. Figure 1 shows a map of the Netherlands and the different areas that are covered by both institutes. The green lines represent the borders of the 19 civil court districts, the red lines those of the 11 PES districts. It is seen that the PES and the civil court districts seldom have similar borders. Only in the north and in the south of the Netherlands both institutes cover equal areas: In the north, the civil court in Leeuwarden and the PES in Leeuwarden cover the exact same municipalities (area 1 in Figure 1). Furthermore, the civil court districts Groningen and Assen together have the same reach as the PES district Groningen (area 2 in Figure 1). In the south of the Netherlands, the PES district Maastricht and the civil court district Maastricht (area 3 in Figure 1) show an overlap of all borders, except for the northern border. The PES district covers a larger area and reaches further north.

In order to decide which of these districts to include in our study we limited ourselves to those areas in which the condition of overlap holds (area 1, area 2 and area 3 in Figure 1), As such, a more thorough investigation of the regions Maastricht, Groningen and Assen and Leeuwarden is conducted. For this purpose we conducted 5 analyses. First, we compared the pattern of the number of dismissal request filed over time in the whole of the Netherlands to that of the regions Maastricht, Groningen, Assen and Leeuwarden. Second, we checked if any of

\footnotetext{
${ }^{108}$ Before, the PES was located at 15 different locations in the Netherlands, however the subsidiaries in Assen, Apeldoorn, Den Bosch and Amsterdam were closed in 2007 due to overcapacity.

${ }^{109}$ At PES, the storage of dismissal files is centralized. As mentioned earlier, all dismissal folders are stored in the archive in Almere. The existence of 56 civil courts in the Netherlands was the largest obstacle to collecting data of all different locations.

${ }^{110}$ Unless agreed upon otherwise by both parties.
} 


\section{CHAPTER 3}

the before mentioned regions are representative regions in terms of size. Third, we checked if these regions are representative regions in terms of other characteristics than size. Fourth, using the PES national database, Chi-square tests are conducted to test on which characteristics the PES districts Maastricht, Groningen and Leeuwarden deviate from the total of all districts. Last, we examined the number of missing values on several key characteristics in the PES national ARCOS database.

Table 2 All PES districts in the Netherlands.

\section{PES: 11 districts †}

\section{Jurisdiction North}

1. Groningen

2. Leeuwarden

Jurisdiction East

3. Hengelo

4. Arnhem

Jurisdiction North-West

5. Haarlem

\section{Jurisdiction Mid-West}

6. The Hague

7. Amersfoort

Jurisdiction South-West

8. Breda

9. Rotterdam

\section{Jurisdiction South-East}

10. Eindhoven

11. Maastricht

tThere used to be 16 PES districts. These were closed due to overcapacity. Assen, Apeldoorn, Zaandam and Den Bosch were closed in 2007, Middelburg was closed in 2004.

Table 3 All civil court in the Netherlands (continued on the next page).

\begin{tabular}{|c|c|}
\hline Civil court: 19 districts & Courts in: \\
\hline \multicolumn{2}{|l|}{ Jurisdiction Leeuwarden } \\
\hline 1. Groningen & Groningen, Winschoten \\
\hline 2. Leeuwarden & Leeuwarden, Sneek, Heerenveen, Opsterland* \\
\hline 3. Assen & Assen, Emmen, Meppel* \\
\hline \multicolumn{2}{|l|}{ Jurisdiction Arnhem } \\
\hline 4. Zwolle & Zwolle, Lelystad, Deventer \\
\hline 5. Almelo & Almelo, Enschede \\
\hline 6. Zutphen & Zutphen, Apeldoorn, Oost Gelre, Harderwijk, Oude ljsselstreek \\
\hline 7. Arnhem & Arnhem, Wageningen, Tiel, Nijmegen \\
\hline
\end{tabular}


Table 3 continued.

\begin{tabular}{|c|c|}
\hline Civil court: 19 districts & Courts in: \\
\hline \multicolumn{2}{|l|}{ Jurisdiction Amsterdam } \\
\hline 8. Utrecht & Utrecht, Amersfoort \\
\hline 9. Alkmaar & Alkmaar, Hoorn, Den Helder \\
\hline 10. Haarlem & Haarlem, Zaandam \\
\hline 11. Amsterdam & Amsterdam, Hilversum \\
\hline \multicolumn{2}{|l|}{ Jurisdiction The Hague } \\
\hline 12. The Hague & Den Haag, Delft, Leiden, Gouda, Alphen a/d Rijn \\
\hline 13. Rotterdam & Rotterdam, Schiedam, Brielle, Middelharnas \\
\hline 14. Dordrecht & Dordrecht, Oud Beijerland, Gorinchem \\
\hline 15. Middelburg & Middelburg, Terneuzen, Tholen* ,Zierikzee* \\
\hline \multicolumn{2}{|l|}{ Jurisdiction Den Bosch } \\
\hline 16. Breda & Breda, Tilburg, Bergen op Zoom \\
\hline 17. Den Bosch & Den Bosch, Eindhoven, Helmond, Boxmeer \\
\hline 18. Roermond & Roermond, Venlo \\
\hline 19. Maastricht & Maastricht, Heerlen and Sittard \\
\hline
\end{tabular}

*This court is closed in 2008.

- Borders of the PES 11 districts

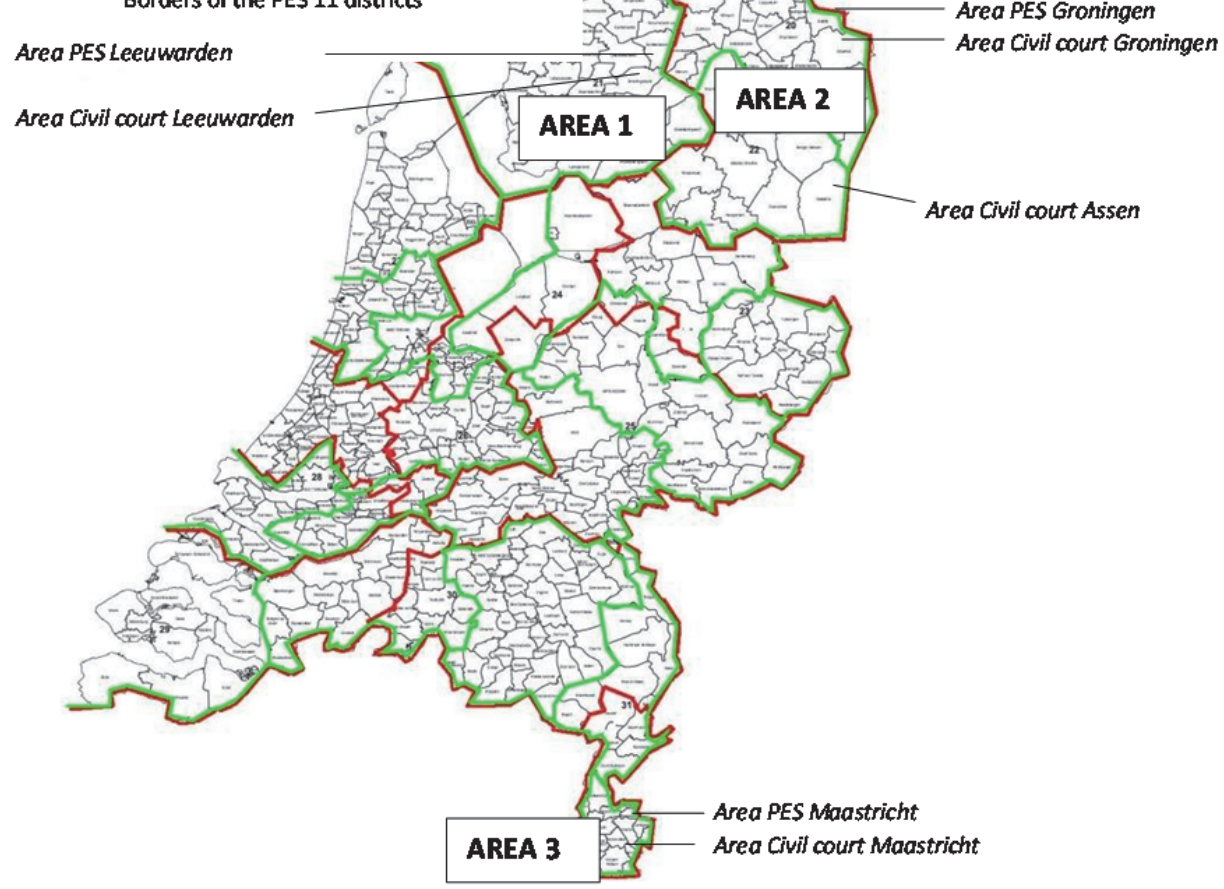

Figure 1 Borders of the civil court districts and of the PES districts.

Source: Raad van Rechtspraak (2009), UWV (2009) 
Jurisdiction North

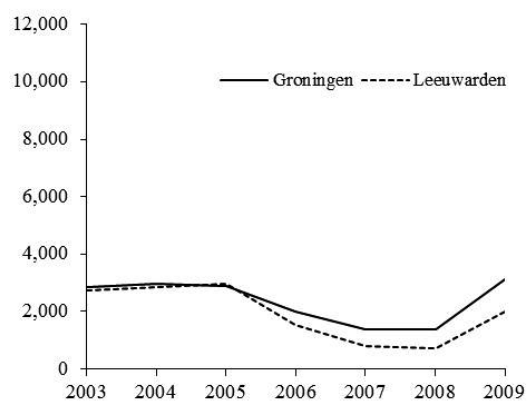

Jurisdictions Mid -West and NorthWest

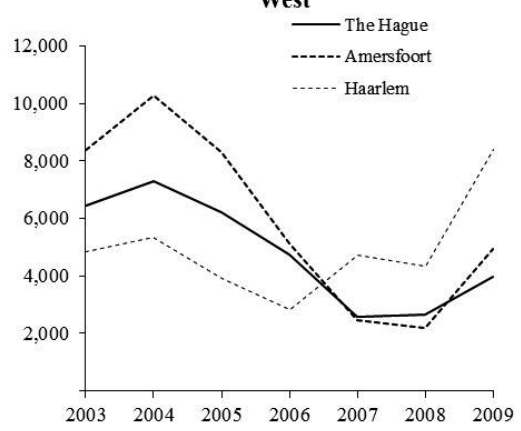

Jurisdiction South-East

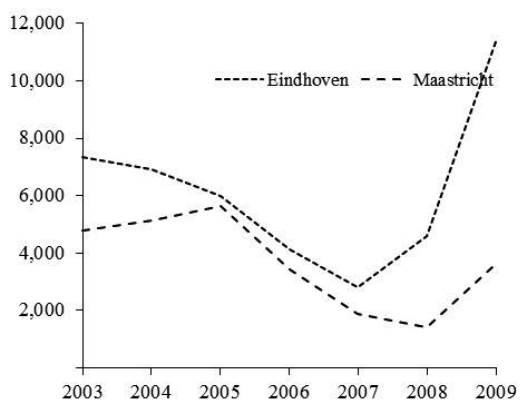

Jurisdiction East

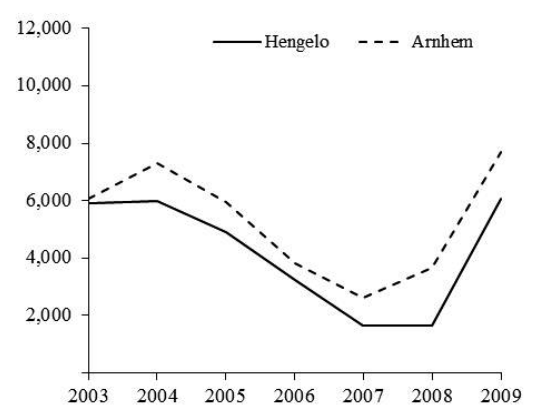

Jurisdiction South-West

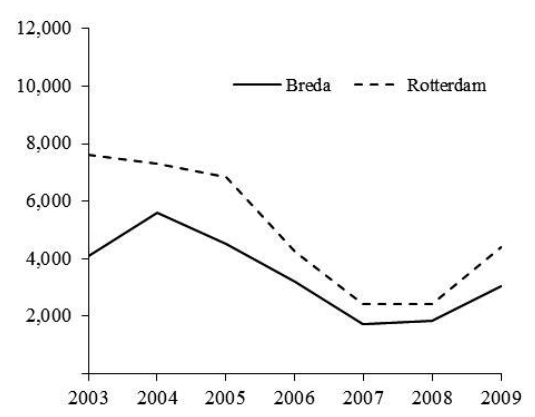

All jurisdictions

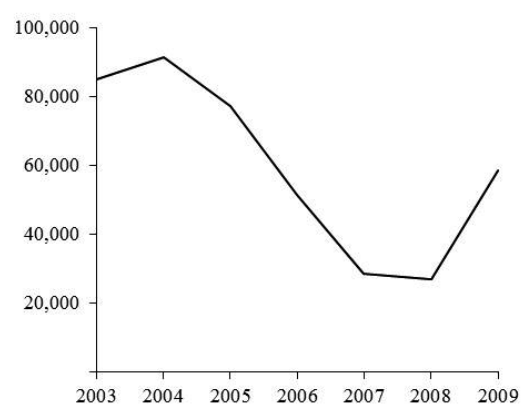

Figure 2a Number of dismissal cases per PES district, displayed per jurisdiction. Source: UWV (2009) 
Districts Maastricht, Groningen and Leeuwarden

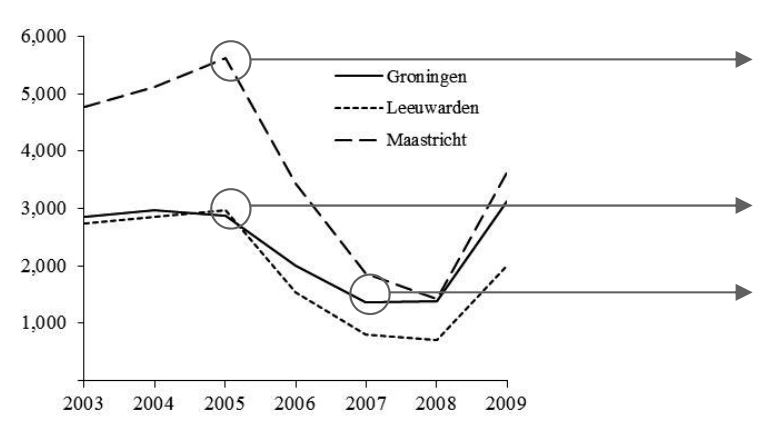

The peak in Maastricht is witnessed in 2005 instead of in 2004 as with the total of all jurisdictionst.

The peak in Leeuwarden is witnessed in 2005 instead of in 2004 as with the total of all jurisdictionst.

The lowest number of dismissal request in Groningen is witnessed in 2007 instead of in 2008 as with the total of all iurisdictionst.

Figure $\mathbf{2 b}$ Maastricht, Groningen and Leeuwarden vs. the total of all jurisdictions.

Source: UWV (2009)

+ With the total of all jurisdiction we mean the sum of requests filed at all locations in the Netherlands. See the graph in the lower right corner of Figure $2 a$ above.

\subsubsection{Pattern of the number of dismissal request handled over time}

First, we examined the pattern of the number of dismissal requests handled at all 11 PES districts and all 19 civil court districts. PES. Comparing the pattern of the total number of dismissal requests handled at all PES locations in the Netherlands to the pattern of the requests handled at the districts Maastricht, Groningen and Leeuwarden, we find that none of these individual districts follow the nationwide pattern (Figure 2a and 2b). Nationwide, the total number of dismissal request handled increases from 2003 to 2004 and decreases from 2004 to 2008. The year 2009 is characterized by a rise in the number of dismissal requests. The PES districts Maastricht and Leeuwarden show an increase in the number of requests during the time period 2003 to 2005, instead of during the time period 2003 to 2004. Groningen shows an increase after 2007, instead of after 2008. Civil court. The total number of dismissal request handled at all civil courts in the Netherlands is the highest in 2003 and the lowest in 2008 (Figure 3a). The number of request handled at the civil court in Maastricht follows the same pattern as the sum of requests handled at all jurisdictions. In both the Maastricht area and in the Netherlands the number of dismissal requests decreases from 2003 to 2008 and increases again in 2009 (Figure 3b). Groningen shows a peak in the number of dismissal requests in 2004 and not in 2003. Leeuwarden shows a peak in 2005 and Assen shows an increase in the number of dismissal request from 2004 to 2006. 
Jurisdiction Leeuwarden

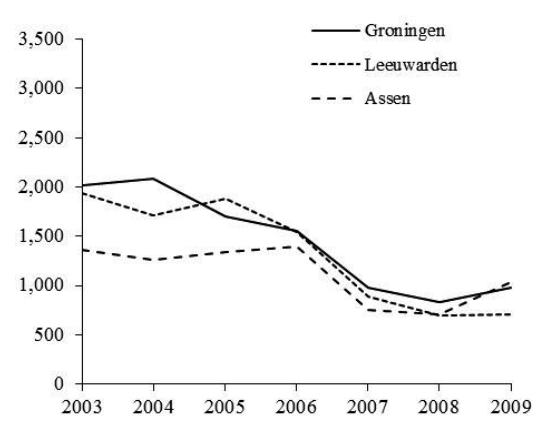

Jurisdiction Amsterdam

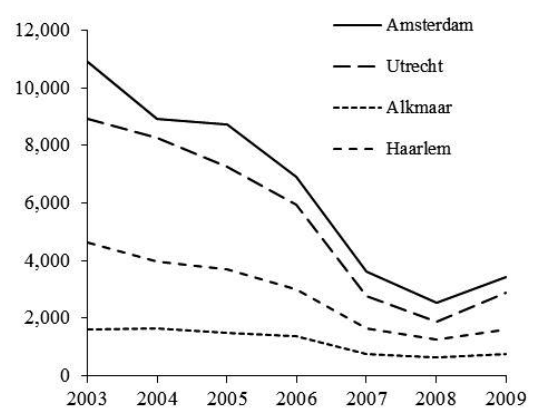

Jurisdiction Den Bosch

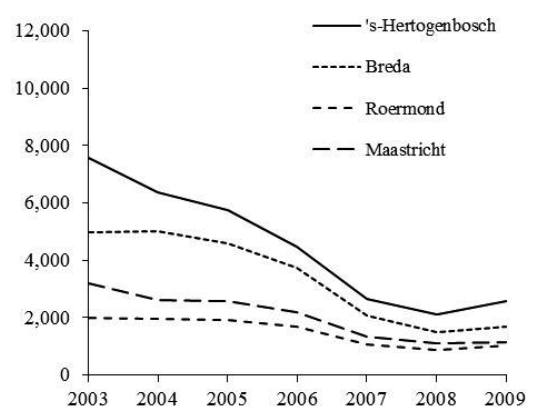

Jurisdiction Arnhem

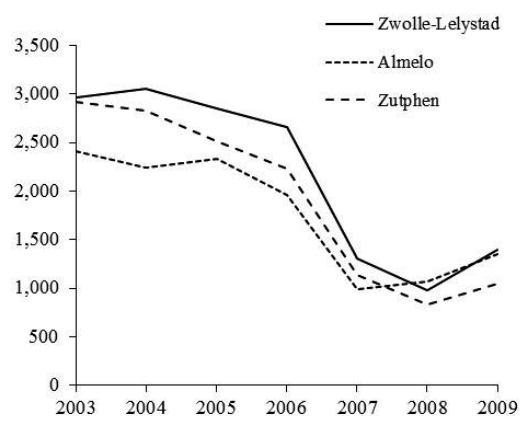

Jurisdiction The Hague

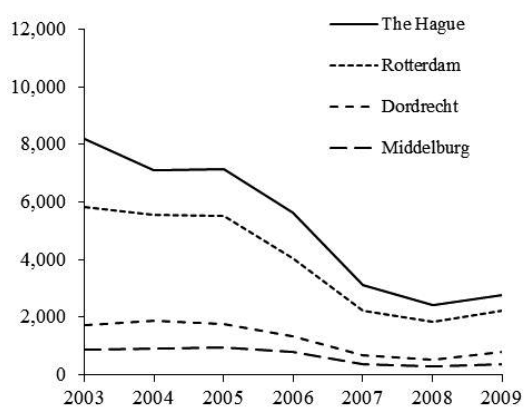

All jurisdictions

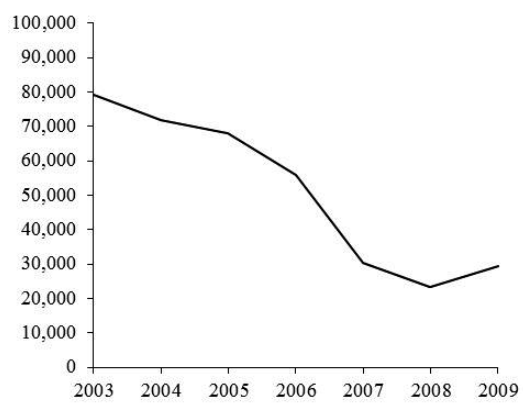

Figure 3a Number of dismissal cases per civil court district. Source: Raad van Rechtspraak (2011) 


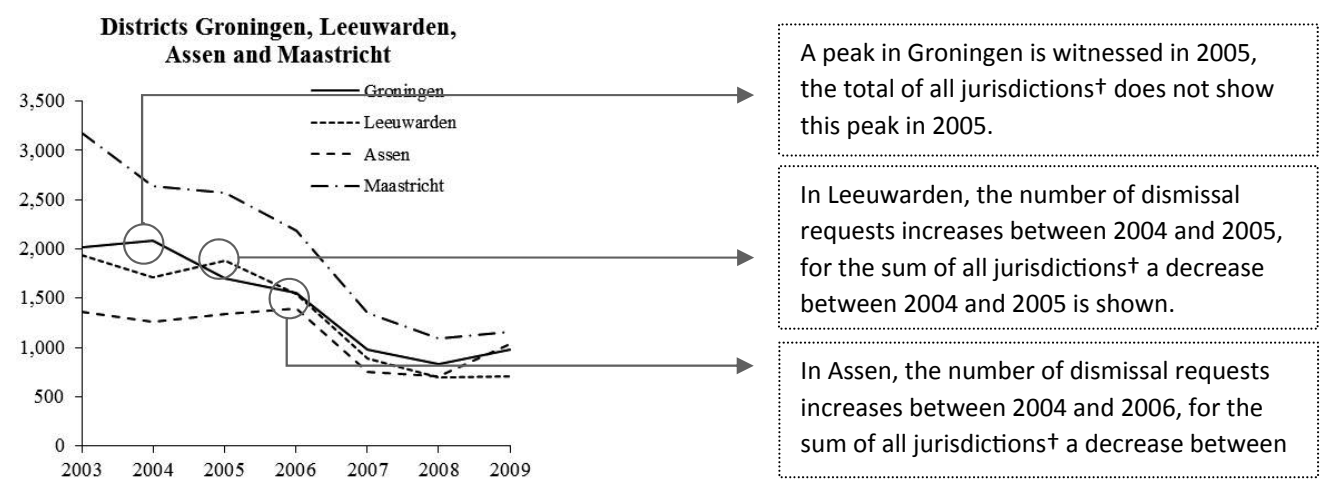

Figure 3b Maastricht, Groningen, Leeuwarden and Assen vs. the total of all jurisdictions.

Source: Raad van Rechtspraak (2011)

+ With the total of all jurisdiction we mean the sum of requests filed at all locations in the Netherlands. See the graph in the lower right corner of Figure $3 a$ above.

\subsubsection{Number of cases handled per location}

Second, an examination of the distribution of cases over all PES and civil court locations is conducted. PES. Table 3 presents the number of dismissal requests handled at all PES districts in ascending order per year. Per year, the mean and median are shown. The differences between the mean and the median are very small and the distribution of cases over the different PES districts is almost symmetrical. The results of Shapiro Wilk's tests conducted for all years show p-values between .181 and .913, indicating normally distributed data for all years. In the years 2005 and 2006, Maastricht represents the median and is close to the mean. In most other years, the number of cases processed in Maastricht is close to the average number of dismissal requests processed. In the year 2008, however, Maastricht is found at the low end of the distribution. Groningen and Leeuwarden are mostly located at the low-end of the distribution. Civil court. Table 4 presents the number of dismissal requests handled at all civil court districts in ascending order per year. Additionally, Table 4 shows the mean and the median per year. The distribution of dismissal request is skewed upwards; for most years the mean is larger than the median. The further we move to the year 2009, the smaller the difference between the median and the mean and thus the more symmetrical the distribution of dismissal request over the different locations becomes. Shapiro Wilk's tests show p-values of less than .05 for all years between 2003 and 2006 and p-values of less than .10 for the years 2006 and 2008. A Shapiro Wilk's test conducted for the year 2007 shows a p-value of .110, a value for which we cannot reject the null hypothesis of normality. We are interested in determining to what extent the districts Leeuwarden, Groningen, Assen and Maastricht are representative for the total population. The mean is driven up by the larger districts Amsterdam, Utrecht and The Hague and is therefore not a representative figure. For this reason, we focus on the median. In the year 2005, the civil court district Maastricht represents the median. In other words, in 2005 eight districts processed more dismissal requests than Maastricht and eight districts processed less dismissal requests than Maastricht. In all other years, Maastricht is always located directly next 
to the median. Leeuwarden, on the other hand, is always located at the low end of the distribution. The same holds for Groningen and Assen.

\subsubsection{Ranking on key characteristics}

As a third analysis to decide which regions to include in our study, we used the national PES ARCOS database to rank the 11 PES locations on different key characteristics. These rankings include all dismissal requests that were handled by all PES subsidiaries in the year 2008 and are used to determine to what extent the districts Maastricht, Groningen, Assen en Leeuwarden are representative for the total population of dismissal requests handled. Because a national civil court dataset does not exist, Central Bureau of Statistics (CBS) data containing several socioeconomic indicators is used to achieve a similar ranking of the 19 civil court districts.

PES. Appendix A shows rankings of the different PES locations on different key characteristics. In each table, percentages of the district total are given and ranked from lowest to highest. Table A1 presents the rankings of the 11 PES subsidiaries based on different dismissal reasons. The upper-left sub table shows the percentage of dismissal requests due to economic reasons as a percentage of all dismissal requests. The country average is 66.08 percent $(17,730$ out of 26,833). Maastricht is below this average; 61.52 percent of all dismissal cases has an economical background ( 873 out of 1,419$)$. Groningen (68.14 percent) and Leeuwarden (71.00 percent) are both above the country average. Of all districts, Maastricht shows the lowest percentage of dismissal requests due to reproachable behavior (2.75 percent). Yet, Maastricht has the highest percentage of requests filed because of illness of the employee (30.80 percent). Regarding this latter category, Leeuwarden and Groningen are close to the country average of 22.98 percent. Table A2 shows that, compared to the country average of 17.31 percent, only few cases in Groningen are collective cases (5.08 percent). Also Leeuwarden ( 7.36 percent) and Maastricht (7.40 percent) score below the country average. Next, Table A3 ranks the different subsidiaries according to the percentage of employees in a certain age category. It shows that the Maastricht district has the lowest percentage of employees in the age category 15 to 24 . Only 46 out of 1,419 cases involve employees below 24 (3.24 percent). Leeuwarden comes second with 3.25 percent ( 23 out of 707 ). The largest share of employees in the age category 15 to 24 is found in Groningen (7.40 percent). As concerns the share of employers from different industries, Table A4 exhibits a Maastricht area that is never found on the extreme of a ranking. Additionally, it shows that Groningen and Leeuwarden receive the lowest percentage of requests of employers in the transport, storage and communication industry and the health and wellness industry, respectively. The share of employers in the construction industry is the highest in Leeuwarden. Last, Table A5 exhibits rankings based on the outcome of the process. In Maastricht, the percentage of dismissal requests granted is 73.78 percent $(1,047$ out of 1,419$)$ whereas the country average is 68.22 percent $(18,305$ out of 26,833$)$. In Groningen, 62.55 percent of all permissions is granted ( 862 out of 1,378 ). In Leeuwarden, permission is granted in 65.49 percent (463 out of 707 ) of all cases 


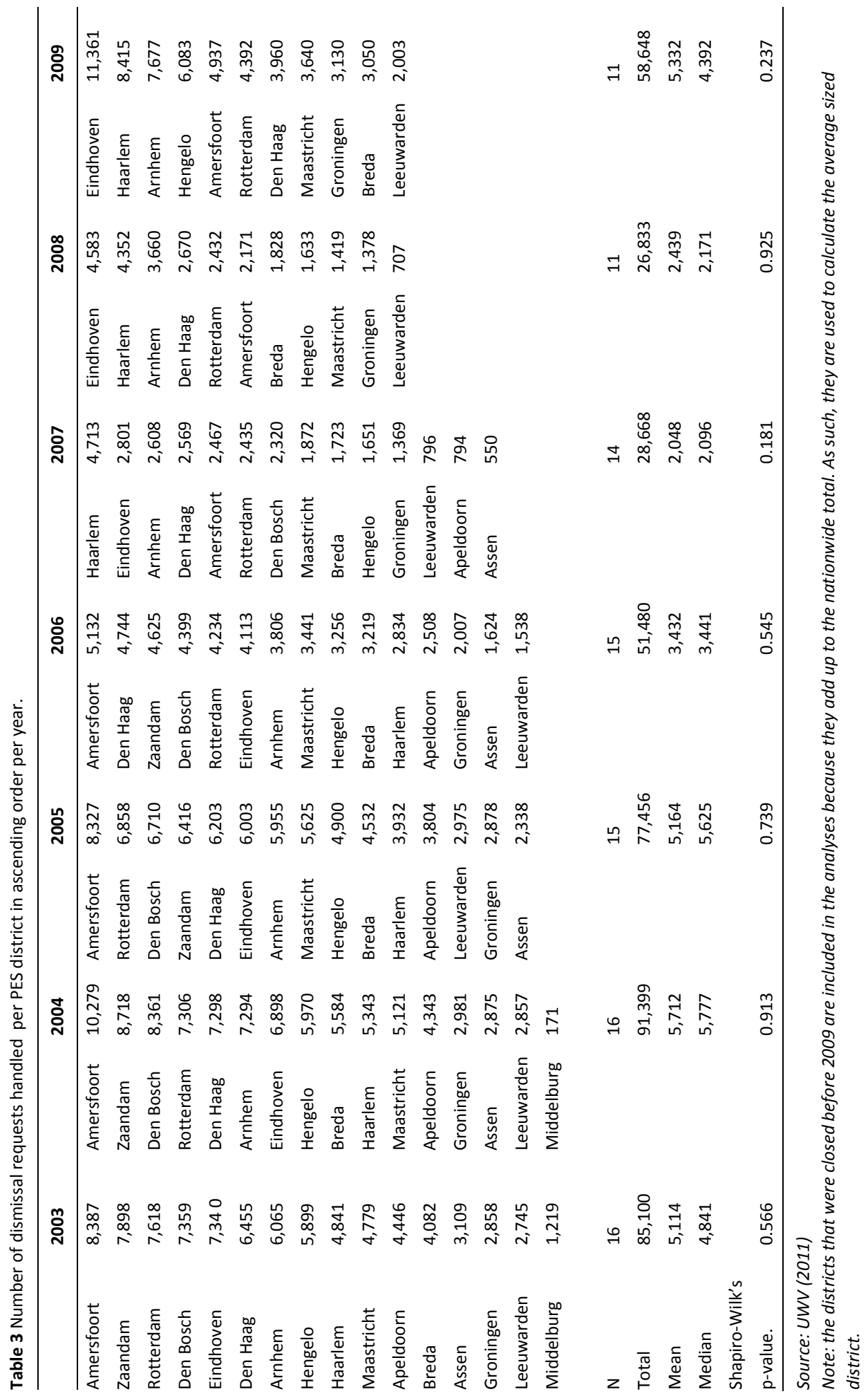




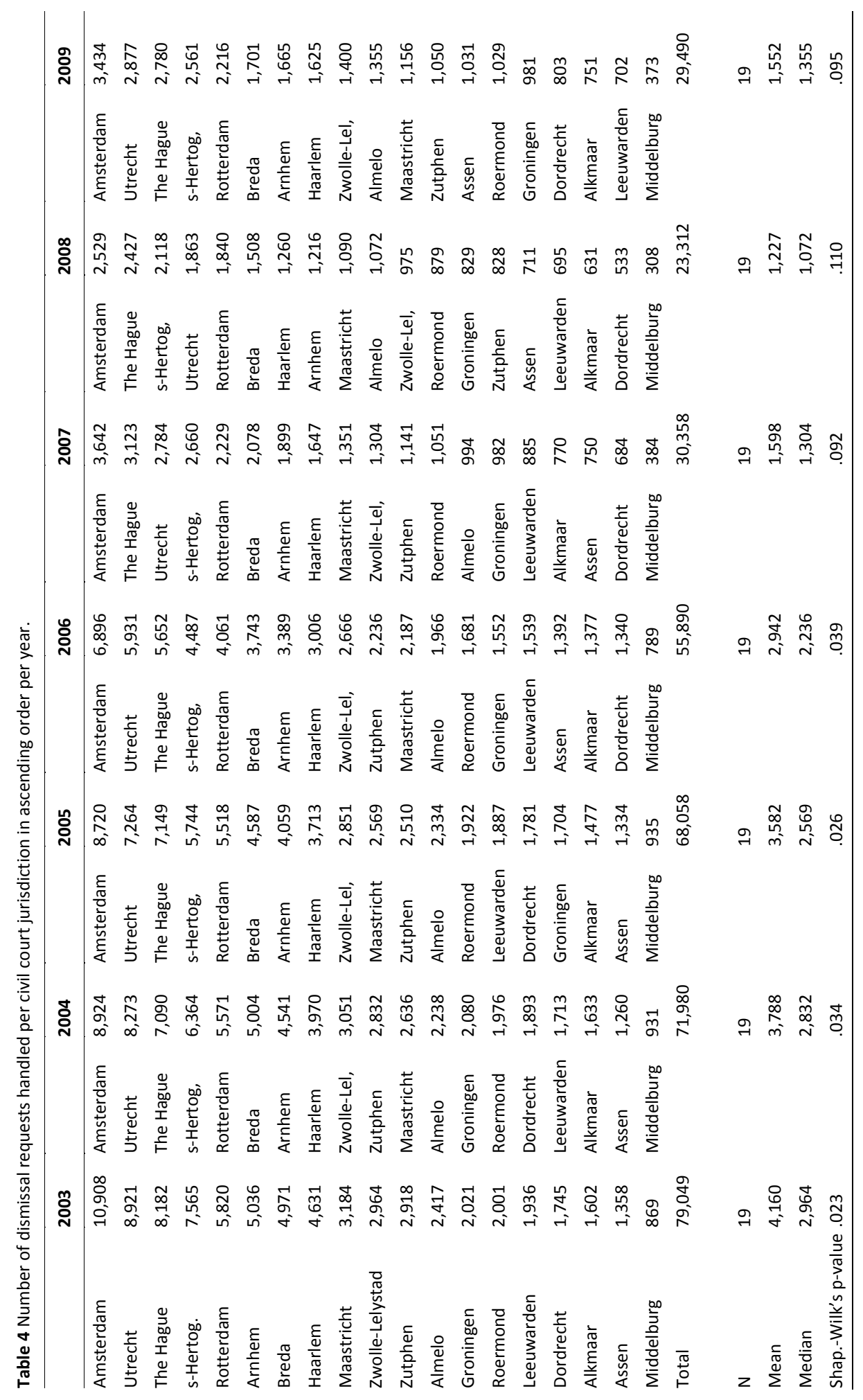


Civil court. Appendix B presents rankings of the different civil court districts on different socioeconomic indicators. Table B1 exhibits the total number of inhabitants of all 19 civil courts districts. With 610,868 and 573,459 inhabitants, respectively, the Maastricht and Groningen district are smaller than the averaged sized district. Yet, with 488,135 inhabitants, the Assen district is much smaller. With 643,189 inhabitants, Leeuwarden represents the median of the distribution. Next, Table B2, most left sub table, shows a ranking on the basis of the number of inhabitants in the non-productive phase of their life as fraction of the number of inhabitants in the productive phase of their life. ${ }^{111}$ This ratio is further referred to as total pressure. The total pressure in the Netherlands is 63.24 percent. With 62.90 percent, the Maastricht district is close to the nationwide average. With ratios of 69.22 and 67.81, respectively, the Assen and the Leeuwarden district are located at the high end of the ranking. Groningen has a relatively low total pressure (60.33 percent). Total pressure can be divided into green pressure and gray pressure. Green pressure refers to the ratio of the number of inhabitants in the age category 0 to 20 to the number of inhabitants in the age category 20 to 65 . Gray pressure measures the ratio of the number of inhabitants that are older than 65 to the number of inhabitants in the age category 20 to 65 . As concerns green pressure, Maastricht and Groningen score relatively low. Leeuwarden and Assen score much higher. Gray pressure is high Maastricht, Assen and Leeuwarden, whereas Groningen comes close to the country average. Table B3 exhibits the share of allochthonous population members. It shows that 17.10 percent of Maastricht's total population is allochthonous with Western origins (104,458 out of 610,868$)$. In Leeuwarden, Assen and Groningen this percentage is much lower. Actually, these three cities are located at the opposite of the ranking, below the country average of 8.83 percent $(1,448,552$ out of $16,405,399)$. As regards minority groups in general, the ratio of the allochtonous population to the total population is the lowest in Leeuwarden and Assen (8.19 and 8.65 percent, respectively). Groningen comes fourth (12.34 percent). With 21.70 percent allochthonous inhabitants, Maastricht is found above the country average of 19.60 percent and is located at the high end of the ranking. Only the big cities The Hague, Rotterdam and Amsterdam score higher. Next, Table B4 presents the percentage of companies in a certain industry as a percentage of the total population of companies. Of all districts, Leeuwarden has the lowest and second lowest percentage of companies in the commercial services industry and the noncommercial services industry. It scores high in terms of companies in the agricultural industry. The Maastricht data show the highest percentage of employers working in non-commercial services. Groningen and Assen do not appear on the high-end or the low-end extreme. Last, in table B5 we examined the number of households living below the social minimum. In the Netherlands, 8.51 percent of all households is living below the social minimum $(616,203$ out of $7,242,202$ households) In the Maastricht, Groningen and Leeuwarden area this percentage is higher. In the Maastricht area 10 percent of all households is living below the social minimum $(28,325$ out of 283,254$)$. In the Groningen area this percentage equals $10.42(28,417$ out of $272,445)$, in the Leeuwarden area it is 9.52 percent $(26,385$ out of 277,053$)$. With 7.57 percent of all households $(16,429$ of 206,146$)$ living below the social minimum the Assen district is close to the country average.

\footnotetext{
${ }^{111}$ Inhabitants between 0 and 20 years of age and of 65 years of age and older are characterized to be in the nonproductive phase of their lives, those between 20 and 65 years of age belong to the latter category.
} 


\subsubsection{Deviation from the nationwide total using Chi-square tests}

Fourth, using data retrieved from the PES national database ${ }^{112}$, Chi-square tests are conducted to test on which characteristics the PES districts Maastricht, Groningen and Leeuwarden deviate from the total of all districts. ${ }^{113}$ Table 5 shows the results of these tests. P-values for Pearson $\chi^{2}$ statistics are reported. The PES district Maastricht is not significantly different from the country total in terms of the percentage of employers that operate in the industry sector $(p=.837)$ and in terms of the percentage of employers that work in the commercial services sector $(p=.557)$. Furthermore, the Maastricht area is not significantly different from the nationwide total as regards the share of persons in the age category 25 to 44 and the share of persons in the age category 65 to 75. For Groningen and Leeuwarden, the null hypothesis of no difference between the district total and the country total cannot be rejected for the percentage of employees that work in commercial services. For Leeuwarden this also holds true for the percentage of employees between 45 and 75 years of age and for the number of dismissal requests being granted.

Chi-square test for the civil court districts cannot be conducted because of the lack of a national dataset including several observations per district. The Central Bureau of Statistics data used to rank the 19 different civil court districts is aggregated on district level and can therefore not be used in this section.

\subsubsection{Analysis of missing values}

As a fifth analysis an examination of the number of missing values on several key characteristics in the PES national database is conducted. We present figures of the year 2008. Because the data that is manually collected from hardcopy dismissal files had to be matched to the data of the PES national ARCOS database, the selection of a district that shows few missing values on key variables in ARCOS is preferable. Table 6 shows that the percentage of missing values is very low for all variables except for company size. For 41.81 percent of 26,833 dismissal cases information about company size is lacking. Table 7 shows that this 41.81 percent is not evenly distributed among districts. The Maastricht data is almost complete; for only 0.35 percent of all 1,419 dismissal cases information about company size is absent. For the Groningen district, in 48.33 percent of all 1,378 observation information on company size is absent. For Leeuwarden, this holds for 28.71 percent of all observations.

\footnotetext{
112 The same data as before is used. ( $n=26,833$, year 2008) One observation represents one individual dismissal case.

${ }^{113}$ As such the proportions of district $X$ are compared to the proportions of the sum of all districts - district X. (e.g. Maastricht versus the sum of all districts excluding Maastricht) Furthermore, chi-square statistics are only shown for the largest categories.
} 
Table 5 Chi-square tests ${ }^{114}$.

\begin{tabular}{|c|c|c|c|c|c|c|c|c|c|c|c|c|}
\hline \multirow[t]{2}{*}{ Dismissal } & \multicolumn{2}{|c|}{ Economical } & \multicolumn{3}{|c|}{ Individual } & \multicolumn{3}{|c|}{ Collective } & \multicolumn{4}{|c|}{ Prolonged illness } \\
\hline & $\%$ & $\mathbf{p}$ & & $\%$ & $\mathbf{p}$ & & $\%$ & $\mathbf{p}$ & & $\%$ & $\mathbf{p}$ & \\
\hline Amersfoort & 57.21 & .000 & - & 51.40 & .010 & + & 5.80 & .000 & - & 29.43 & .000 & + \\
\hline Arnhem & 73.39 & .000 & + & 41.64 & .000 & - & 31.75 & .000 & + & 18.03 & .000 & - \\
\hline Breda & 66.30 & .832 & & 46.55 & .050 & - & 19.75 & .004 & + & 24.18 & .204 & + \\
\hline Eindhoven & 71.52 & .000 & + & 47.79 & .147 & & 23.72 & .000 & + & 20.10 & .000 & - \\
\hline Groningen & 68.14 & .096 & + & 63.06 & .000 & + & 5.08 & .000 & - & 22.57 & .715 & \\
\hline Haarlem & 60.97 & .000 & - & 50.64 & .007 & + & 10.32 & .000 & - & 23.90 & .113 & + \\
\hline Hengelo & 71.65 & .000 & + & 54.56 & .000 & + & 17.09 & .800 & & 19.35 & .000 & - \\
\hline Leeuwarden & 71.00 & .005 & + & 63.65 & .000 & + & 7.36 & .000 & - & 20.37 & .095 & - \\
\hline Maastricht & 61.52 & .000 & - & 54.12 & .000 & + & 7.40 & .000 & - & 30.80 & .000 & + \\
\hline Rotterdam & 63.53 & .005 & - & 47.82 & .331 & & 15.71 & .029 & - & 23.03 & .946 & \\
\hline The Hague & 61.09 & .000 & - & 39.63 & .000 & - & 21.46 & .000 & + & 25.99 & .000 & + \\
\hline Industry & \multicolumn{2}{|l|}{ Industry } & \multicolumn{3}{|c|}{ Wholesale } & \multicolumn{3}{|c|}{ Commercial serv. } & \multicolumn{4}{|c|}{ Health and wellness } \\
\hline Amersfoort & 11.24 & .000 & - & 25.66 & .049 & + & 29.16 & .000 & + & 12.57 & .228 & \\
\hline Arnhem & 27.13 & .000 & + & 18.11 & .000 & - & 15.05 & .001 & - & 18.77 & .000 & + \\
\hline Breda & 24.62 & .000 & + & 30.03 & .000 & + & 13.57 & .000 & - & 9.74 & .000 & - \\
\hline Eindhoven & 32.02 & .000 & + & 21.58 & .000 & - & 13.03 & .000 & - & 11.50 & .000 & - \\
\hline Groningen & 7.33 & .000 & - & 29.39 & .000 & + & 16.47 & .658 & & 9.07 & .000 & - \\
\hline Haarlem & 7.06 & .000 & - & 27.76 & .000 & + & 23.28 & .000 & + & 11.33 & .000 & - \\
\hline Hengelo & 28.35 & .000 & + & 24.98 & .302 & & 15.62 & .150 & & 11.57 & .024 & - \\
\hline Leeuwarden & 7.64 & .000 & & 28.43 & .004 & + & 15.28 & .241 & & 8.49 & .000 & - \\
\hline Maastricht & 16.98 & .837 & & 27.41 & .002 & + & 17.48 & .557 & & 15.15 & .049 & + \\
\hline Rotterdam & 5.67 & .000 & - & 19.41 & .000 & - & 11.02 & .000 & - & 15.95 & .000 & + \\
\hline The Hague & 1.72 & .000 & & 21.72 & .005 & - & 14.57 & .001 & - & 17.45 & .000 & + \\
\hline Age categories & $15-24$ & & & $25-44$ & & & $45-64$ & & & $65-75$ & & \\
\hline Amersfoort & 4.88 & .210 & & 43.62 & .289 & & 50.07 & .135 & & 1.01 & .267 & + \\
\hline Arnhem & 3.63 & .021 & - & 41.99 & .472 & & 53.52 & .012 & + & 0.44 & .007 & \\
\hline Breda & 4.92 & .219 & & 37.04 & .000 & - & 56.29 & .000 & + & 0.93 & .549 & \\
\hline Eindhoven & 3.80 & .041 & - & 41.92 & .347 & & 52.89 & .056 & + & 0.55 & .029 & - \\
\hline Groningen & 7.40 & .000 & + & 44.70 & .096 & + & 46.66 & .000 & - & 0.36 & .058 & - \\
\hline Haarlem & 4.94 & .039 & + & 46.05 & .000 & + & 47.20 & .000 & - & 1.06 & .046 & + \\
\hline Hengelo & 5.27 & .063 & + & 42.99 & .706 & & 49.72 & .117 & & 0.86 & .821 & \\
\hline Leeuwarden & 3.25 & .145 & & 42.01 & .772 & & 52.48 & .639 & & 0.42 & .247 & \\
\hline Maastricht & 3.24 & .035 & - & 40.66 & .141 & & 54.40 & .030 & + & 1.13 & .168 & \\
\hline Rotterdam & 3.66 & .077 & - & 39.80 & .004 & - & 55.10 & .000 & + & 1.07 & .133 & \\
\hline The Hague & 3.93 & .258 & & 43.78 & .171 & & 50.79 & .373 & & 1.01 & .218 & \\
\hline
\end{tabular}

\footnotetext{
${ }^{114}$ Chi-square tests for dismissal reason are only conducted for the largest categories.
} 
Table 5 continued.

\begin{tabular}{lccc}
\hline Granted & Yes & & \\
& $\%$ & p & \\
\hline Amersfoort & 61.31 & .000 & - \\
Arnhem & 71.39 & .000 & + \\
Breda & 62.86 & .000 & - \\
Eindhoven & 71.85 & .000 & + \\
Groningen & 62.55 & .000 & - \\
Haarlem & 74.45 & .000 & + \\
Hengelo & 63.56 & .000 & - \\
Leeuwarden & 65.49 & .114 & \\
Maastricht & 73.78 & .000 & + \\
Rotterdam & 62.87 & .000 & - \\
The Hague & 65.17 & .000 & - \\
\hline
\end{tabular}

Source: UWV (2009)

\subsubsection{Selecting the Maastricht region}

In selecting districts for data collection, the absence of overlap of borders of PES and civil court districts in a specific region was a constraining factor. As a consequence, only the districts Groningen, Assen, Leeuwarden and Maastricht were considered as possible options. The analyses presented above show that it is difficult to state which of these districts is representative for the Netherlands in total. The rankings in appendices $A$ and $B$ do not provide clear cut answers, as districts appear on different positions on the rankings. A position on a ranking is very much dependent on which criterion is used to construct this ranking. The Chisquare tests presented in Table 5 also do not give an indication of which districts to select. The rankings based on the size of the districts in Table 3 and Table 4, however, do present a Maastricht districts that is better in terms of representatives than the northern districts. Last, the analysis of missing values shows that Maastricht has the lowest number of missing values for the variable company size. Combining the analyses that are conducted in this section of this chapter, made us determine to collect data in the Maastricht region only. The rankings in Table 3 and Table 4, in which we show that Maastricht is closest to the average district in terms of size, and the analysis of missing values in Table 7, which shows that the ARCOS data on the Maastricht area is the most complete of all districts, led to this decision. Another option would have been to collect data on a nationwide scale. However, as we mentioned earlier, collecting data on a nationwide scale implies visiting all 19 civil court districts with courts located at 56 locations spread all over the Netherlands. In terms of time and costs, this was not a feasible option. 
Table 6 Missing values, total PES, year 2008, n=26.833 (continued on the next page).

\begin{tabular}{|c|c|c|c|c|c|}
\hline Subsidiary & $\mathbf{n}$ & $\%$ of total & Dismissal reason & $\mathbf{n}$ & $\%$ of total \\
\hline Amersfoort & 2,171 & 8.09 & Economical & 17,730 & 66.08 \\
\hline Arnhem & 3,660 & 13.64 & Dysfunctional & 645 & 2.40 \\
\hline Breda & 1,828 & 6.81 & Disturbed relationship & 354 & 1.32 \\
\hline Eindhoven & 4,582 & 17.08 & Reproachable behavior & 1,344 & 5.01 \\
\hline Groningen & 1,378 & 5.29 & Frequent illness & 46 & 0.17 \\
\hline Haarlem & 4,351 & 16.22 & Prolonged illness & 6,166 & 22.98 \\
\hline Hengelo & 1,633 & 6.09 & Reintegration measures ${ }^{\dagger}$ & 237 & 0.88 \\
\hline Leeuwarden & 707 & 2.63 & Missing values & 311 & 1.16 \\
\hline Maastricht & 1,419 & 5.29 & Total & 26,833 & 100 \\
\hline Rotterdam & 2,432 & 9.06 & & & \\
\hline The Hague & 2,670 & 9.95 & & & \\
\hline Missing values & 0 & 0 & & & \\
\hline Total & $2, .833$ & 100 & & & \\
\hline Age category & $\mathbf{n}$ & $\%$ of total & Industry & $\mathbf{n}$ & $\%$ of total \\
\hline Category $15-24$ & 1,169 & 4.36 & Industry & 4,504 & 16.79 \\
\hline Category 25-44 & 11,415 & 42.54 & Wholesalet+ & 6,421 & 23.93 \\
\hline Category 44-65 & 13,847 & & Transport††† & 1,367 & 5.09 \\
\hline Category >65 & 217 & 0.81 & Hotel and catering & 806 & 3.00 \\
\hline Missing values & 185 & 0.69 & Commercial services & 4,537 & 16.91 \\
\hline \multirow[t]{6}{*}{ Total } & 26,833 & 100 & Health and wellness & 3,601 & 13.42 \\
\hline & & & Culture and recreation & 2,433 & 9.07 \\
\hline & & & Construction & 1,340 & 4.99 \\
\hline & & & Other & 1,585 & 5.91 \\
\hline & & & Missing values & 239 & 0.89 \\
\hline & & & Total & 26,833 & 100 \\
\hline Collective case & $\mathbf{n}$ & $\%$ of total & Permission & $\mathbf{n}$ & $\%$ of total \\
\hline Yes & 4,646 & 17.31 & Granted & 18,305 & 68.22 \\
\hline No & 22,187 & 82.69 & Not granted & 1600 & 5.96 \\
\hline Missing values & 0 & 0 & Case not treated & 1,666 & 6.21 \\
\hline \multirow[t]{3}{*}{ Total } & 26,833 & 100 & Case withdrawn & 5,262 & 19.21 \\
\hline & & & Missing values & 9 & 0.03 \\
\hline & & & Total & 26,833 & 100 \\
\hline Size (\# of empl.) & $\mathbf{n}$ & $\%$ of total & Tenure in years & $\mathbf{n}$ & $\%$ of total \\
\hline$<10$ & 4,291 & 15.99 & 0 to 10 years & 18,657 & 69.53 \\
\hline $10-100$ & 7,185 & 26.78 & 11 to 20 years & 4,268 & 15.91 \\
\hline$>100$ & 4,139 & 15.43 & 21 to 30 years & 1,817 & 6.77 \\
\hline Missing values & 11,218 & 41.81 & more than 30 years & 901 & 3.36 \\
\hline \multirow[t]{2}{*}{ Total } & 26,833 & 100 & Missing values & 1,190 & 4.43 \\
\hline & & & Total & 26,833 & 100 \\
\hline
\end{tabular}


Table 6 Continued.

\begin{tabular}{lcc}
\hline Gender & $\mathbf{n}$ & \% of total \\
\hline Male & 13,812 & 51.47 \\
Female & 12,730 & 47.44 \\
Missing values & 291 & 1.08 \\
Total & 26,833 & 100 \\
\hline
\end{tabular}

Source: UWV national ARCOS data base (2008)

+ Not cooperating with reintegration measures.

t+ Wholesale, trade, resale trade and repairs.

+++ Transport, storage and communication.

Table 7 Missing values for company size per PES location, year 2008.

\begin{tabular}{lcccccc}
\hline & $<\mathbf{1 0}$ & $\mathbf{1 0 - 1 0 0}$ & $\mathbf{> 1 0 0}$ & missing & $\mathbf{n}$ & \% missing of $\mathbf{n}$ \\
\hline Amersfoort & 567 & 762 & 374 & 468 & 2,171 & 21.56 \\
Arnhem & 618 & 1,469 & 398 & 1,175 & 3,660 & 32.10 \\
Breda & 97 & 31 & 44 & 1,656 & 1,828 & 90.59 \\
Eindhoven & 1,001 & 1,608 & 1,523 & 451 & 4,583 & 9.84 \\
Groningen & 329 & 249 & 134 & 666 & 1,378 & 48.33 \\
Haarlem & 534 & 483 & 418 & 2,917 & 4,352 & 67.03 \\
Hengelo & 430 & 613 & 512 & 78 & 1,633 & 4.78 \\
Leeuwarden & 185 & 230 & 89 & 203 & 707 & 28.71 \\
Maastricht & 346 & 845 & 223 & 5 & 1,419 & 0.35 \\
Rotterdam & 57 & 40 & 224 & 2,111 & 2,432 & 86.80 \\
The Hague & 127 & 855 & 200 & 1,488 & 2,670 & 55.73 \\
Total & 4,291 & 7,185 & 4,139 & 11,218 & 26,833 & 41.81 \\
\hline
\end{tabular}

Source: PES national ARCOS data base (2008)

\subsection{Sample selection}

PES data is collected for the years 2006 to 2009, civil court data is collected for the years 2003 to $2009 .{ }^{115}$ In order to select the dismissal files to use for the construction of our final dataset we randomly selected 20 percent of the population total.

PES. In the years 2006 to 2008, the PES handled 10,361 dismissal requests. All files documenting these 10,361 dismissal requests are stored in 1,671 folders. 20 percent of these 1,671 folders was selected for review, which equals a total of 334 folders. ${ }^{116}$ Of the 334 folders selected, 19 folders were not available or unreadable. The remaining 315 folders included 1,818 dismissal files. This selection of 1,818 dismissal files equals $18 \%$ of the total of all dismissal files $(1,818$ out of 10,361$)$. For reasons mentioned earlier, the borders of the civil court district and of the PES

\footnotetext{
${ }^{115}$ We would have preferred to also collect PES data for the years 2003 to 2005, however, the PES national archive did not store dismissal files dating before 2006.

${ }^{116}$ When selecting one file, the complete folder containing that file had to be ordered.
} 
Table 8 Coverage of the civil court and the PES district Maastricht.

\begin{tabular}{|c|c|c|}
\hline Civil Court Maastricht & PES Maastricht & Overlap \\
\hline \multicolumn{3}{|l|}{ Subdivision Maastricht } \\
\hline $\begin{array}{l}\text { Eijsden, Gulpen-Wittem, Maastricht, } \\
\text { Margraten, Meerssen, Vaals, } \\
\text { Valkenburg aan de Geul }\end{array}$ & $\begin{array}{l}\text { Eijsden, Gulpen-Wittem, Maastricht, } \\
\text { Margraten, Meerssen, Vaals, } \\
\text { Valkenburg aan de Geul }\end{array}$ & Complete overlap \\
\hline \multicolumn{3}{|l|}{ Subdivision Heerlen } \\
\hline $\begin{array}{l}\text { Brunssum, Heerlen, Kerkrade, } \\
\text { Landgraaf, Nuth, Simpelveld, } \\
\text { Voerendaal }\end{array}$ & $\begin{array}{l}\text { Brunssum, Heerlen, Kerkrade, } \\
\text { Landgraaf, Nuth, Simpelveld, } \\
\text { Voerendaal }\end{array}$ & Complete overlap \\
\hline
\end{tabular}

\section{Subdivision Sittard}

Beek, Onderbanken, Schinnen, Sittard-Beek, Onderbanken, Schinnen, Sittard-Complete overlap Geleen, Stein.

Geleen, Stein.

Echt-Susteren, Leudal, Maasgouw, Not covered by the working district of Roerdalen, Roermond. the civil court Maastricht

need to overlap. Figure 1 of this chapter shows that this is not the case for the Northern borders of the Maastricht area. To ensure complete overlap, the case files involving employees that do not live or work in municipalities that are covered by the civil court in Maastricht were excluded from our sample. Table 8 shows and overview of the reach of both institutes and of the municipalities that are excluded.

In 211 out of 1,818 dismissal files examined, the written defense of the employer was not enclosed. As the written defense contains the majority of information needed, these files were also excluded from our sample. After a period of three and a half months, and after reading all 1,818 dismissal files, information on 1,268 PES dismissal cases is included in the final data set (Table 9).

Table 9 Number of dismissal files included and excluded.

\begin{tabular}{lc}
\hline Dismissal files & 1,268 \\
\hline Number of dismissal files included in sample: & 339 \\
Number of dismissal files from sample because of lack of overlap: & 211 \\
Number of dismissal files excluded from sample because of lack of usable information: & 1,818 \\
\hline
\end{tabular}

Civil court. As mentioned before, the civil court district Maastricht has courts located in Maastricht, Heerlen and Sittard. For the years 2003 to 2009, the total number of dismissal requests brought to court in the Maastricht district is 14,207 . The Heerlen civil court is the largest court with a total of 5,260 received requests, followed by Maastricht with a total of 4,699 received requests. With 4,248 requests received, Sittard is the smallest court. A random selection of $20 \%$ of the population total, evenly distributed across the three courts, resulted in 
2,842 selected files. Of these 2,842 dismissal files, 38 files were not accessible. The remaining 2,803 files represent 19,73 percent of the population total.

\subsection{Representativeness of sample}

To test the representativeness of the PES data, we compare our sample to the total population in terms of 5 variables that are present in the PES national ARCOS data base: 1) the outcome of the process, 2) reason for dismissal, 3) industry, 4) size and 5) gender. More specifically, we conduct chi-square tests to analyze if the proportions found in the population total deviate from proportions found in our selection of 1,818 dismissal files. ${ }^{117,118}$ The total population of dismissal files handled by PES equals 10.361 for the period $2006-2009(3,441+1,872+1,419+3,640$, see Table 3). Table 10 displays the Chi-square test results.

With regards to the outcome of the trial, Table 10 shows that 4.01 percent of all requests in our original selection is not granted. This percentage is very close to the percentage nongranted requests in the total population (3.74 percent). A chi-square value of .298 ( $p=.585$ ) indicates that this difference between the original selection and the total population of dismissal requests is not significant. The difference between the number dismissal requests granted in the total population and the original selection is insignificant at a 1 percent level, but significant at a 5 percent level $\left(\chi^{2}=4.586 ; p=.032\right)$. Other non-significant differences are found for the percentage of requests filed due to economic reasons $\left(\chi^{2}=2.542 ; p=.111\right)$ and for the percentage of requests filed because of prolonged illness $\left(\chi^{2}=0.829 ; p=.362\right)$. Moreover, the distribution of employers over the different industry sectors is similar across groups, except for the wholesale, trade and repairs industry $\left(\chi^{2}=14.063 ; p=.000\right)$. Additionally, the distribution of small, medium and large sized employees is equal for both groups. Chi-square values range from $3.126(p=.077)$ to $0.0786(p=0.106)$. Last, the proportion of men in our original selection is equal to the proportion of men in the total population $\left(\chi^{2}=, 006 ; p=, 0,939\right)$. From the results of the chisquare tests, we may conclude that we drew a sample that is representative for the whole population. Proportions from our original selection hardly deviate from the total population proportions.

\footnotetext{
${ }^{117}$ We use the original selection of 1,818 cases because these 1.818 cases cover the same area as the total population. The sample of 1,268 cases does not because of the exclusion of cases in the non-overlapping municipalities (see Table 8). As mentioned earlier in this chapter, of these 1,818 dismissal files, 399 files were excluded from our dataset because of a lack of overlap and 211 files were excluded because of a lack of information. ${ }^{118}$ We also compared the total population to our sample of 1,268. Results are similar to the results in Table 10.
} 
Table 10 Chi square tests to check for representativeness of sample.

\begin{tabular}{|c|c|c|c|c|}
\hline & $\begin{array}{l}\text { Population Total } \\
\qquad n=10,372\end{array}$ & $\begin{array}{l}\text { Original selection } \\
\qquad n=1,818\end{array}$ & $x^{2}$ & $\mathbf{p}$ \\
\hline \multicolumn{5}{|c|}{ Outcome of the process in $\%$} \\
\hline Permission not granted & 3.74 & 4.01 & .298 & .585 \\
\hline Permission granted & 73.82 & 76.21 & 4.586 & 0.032 \\
\hline Other & 22.44 & 19.78 & 6.312 & 0.012 \\
\hline \multicolumn{5}{|l|}{ Reason for dismissal } \\
\hline Economical & 72.19 & 70.36 & 2.542 & 0.111 \\
\hline Prolonged illness & 21.85 & 20.89 & 0.829 & 0.362 \\
\hline Other & 5.96 & 8.75 & 19.997 & 0.000 \\
\hline \multicolumn{5}{|l|}{ Industry of employer in \% } \\
\hline Industry & 23.28 & 21.39 & 3.076 & 0.079 \\
\hline \multicolumn{4}{|c|}{ Wholesale, trade, resale trade and } & 0.000 \\
\hline Commercial services & 17.30 & 16.21 & 1.266 & 0.261 \\
\hline Health and wellness & 13.42 & 12.14 & 2.153 & 0.142 \\
\hline Other & 24.89 & 25.18 & 0.069 & 0.739 \\
\hline \multicolumn{5}{|l|}{ Size employer in \% } \\
\hline less than 10 & 18.76 & 19.66 & 0.0786 & 0.375 \\
\hline between 10 and 100 & 58.74 & 59.75 & 0.622 & 0.430 \\
\hline more than 100 & 22.50 & 20.59 & 3.126 & 0.077 \\
\hline \multicolumn{5}{|l|}{ Gender in \% } \\
\hline Men & 54.47 & 54.57 & 0.006 & 0.939 \\
\hline
\end{tabular}

\subsection{Variables collected and missing data}

This section gives an overview of the variables collected and missing data per variable. It does not give a detailed overview of descriptive statistics. These are given in more detail in the following chapters of this dissertation. We furthermore show how we narrow down our dataset to adapt it to the scope of this dissertation.

Table 11 shows the variables that are present in the PES data, together with the number of missing values. The main employee specific variables collected are the wage of the employee, age, tenure and working hours per week. The main employer specific variables are industry employed, size and legal form. Variables related to the dismissal itself are reason for dismissal, duration of the process and the decision of the PES. The largest numbers of missing values are reported for the variables Hourly wage and Monthly wage.

Table 12 shows the variables that are present in the civil court data. The number of missing values are moreover reported. The main employee specific variables collected are the wage of the employee, age, tenure and working hours per week. The main employer specific variables are industry employed, size and legal form. Variables related to the dismissal itself are reason 
for dismissal, pro-forma, duration of the process and the decision of the civil court. The largest numbers of missing values are reported for the variables Hourly wage and Size of employer.

Instead of deleting observations that include missing values, we estimated the missing data using the non-missing information in the dataset. As a result of this estimation our final and complete dataset contains 1,162 PES observations and 2,390 civil court observations. Appendix $C$ and Appendix $D$ show the exact details of the estimation method used.

The scope of this dissertation is workers with a permanent contract. We are furthermore not interested in civil court cases in which the plaintiff is the employee. Table 13 shows the PES data and the civil court data and the distribution within this data with respect to contract form, plaintiff and year. With respect to the PES data, 28 requests of all 1,162 requests involve employees with a fixed term contract. These 28 requests are excluded in further analyses of this dissertation, 1,134 dismissal cases involving employees with a permanent contract remain. With respect to the civil court data, 106 requests of all 2.390 requests involve employees with a fixed term contract. These are excluded in further analyses. The remaining 2,284 dismissal cases involve employees with a permanent contract. 27 of the 2,284 dismissal requests were filed by the employee, not the employer. In connection with the scope of this dissertation these 27 cases are excluded from further analyses. 2,257 civil court cases remain; of which 1,315 cases were closed in the period 2003-2005 and 942 cases were closed in the period 2006-2009.

\subsection{Conclusion}

We have collected a representative sample of 3,391 dismissal cases of which 1,134 are filed at the PES in the period 2006-2009 and 2,257 are filed at the civil court in the period 2003-2009. Each dismissal case filed at the PES is recorded in an Automation of Reports and Consolidated Orders System (ARCOS) data base. The information included in the data base keeps track of a small number of employer and employee related characteristics, the reason for dismissal, and the duration of the dismissal procedure. Additional information about each case is kept in hardcopy folders that are stored in a national archive located in the city of Almere. With respect to the civil court, an electronic database allows the civil court to keep track of the number of dismissal cases filed each year. It does not, however, contain any detailed information on the contents of a case. Detailed information is stored in a hard-copy folder.

In order to collect our sample, we collected information out of these hard copy folders of civil court cases and PES dismissal files and stored this data electronically. Collection of data for the Netherlands in total, however, implies visiting all 19 civil court districts with courts located at 56 locations spread all over the country. In terms of costs and logistics, this was not a feasible option. As a consequence, a thorough analysis of multiple data sources made us draw the conclusion to only include cases filed at the Maastricht area. A first factor that led to this decision is the fact that the borders of the PES and the civil court in this area are to a large extent similar. A second factor is that in terms of size, the Maastricht districts are closest to the nationwide average. Third, in terms of missing values, the ARCOS data base covering the data of the PES district of Maastricht is the most complete. 


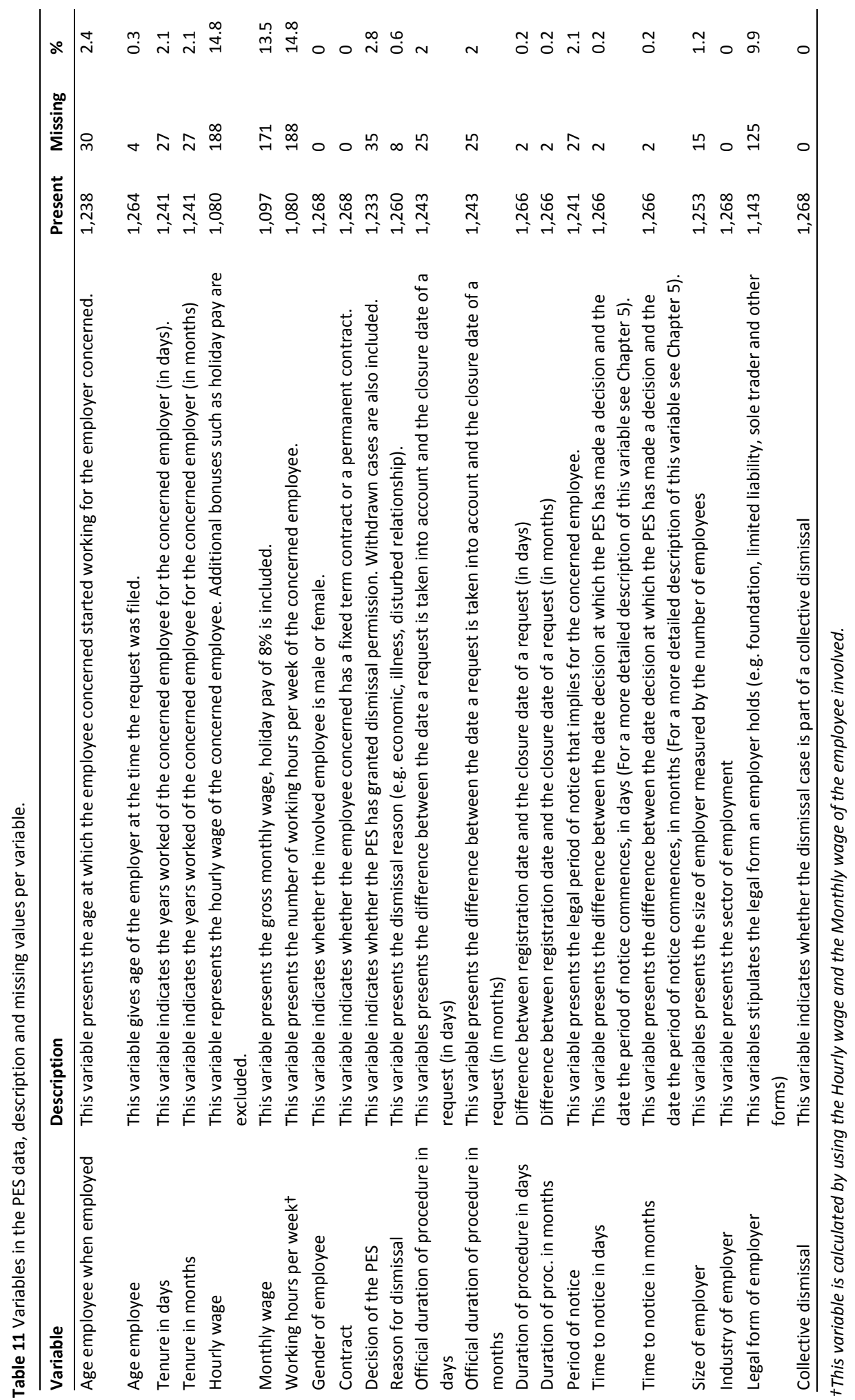




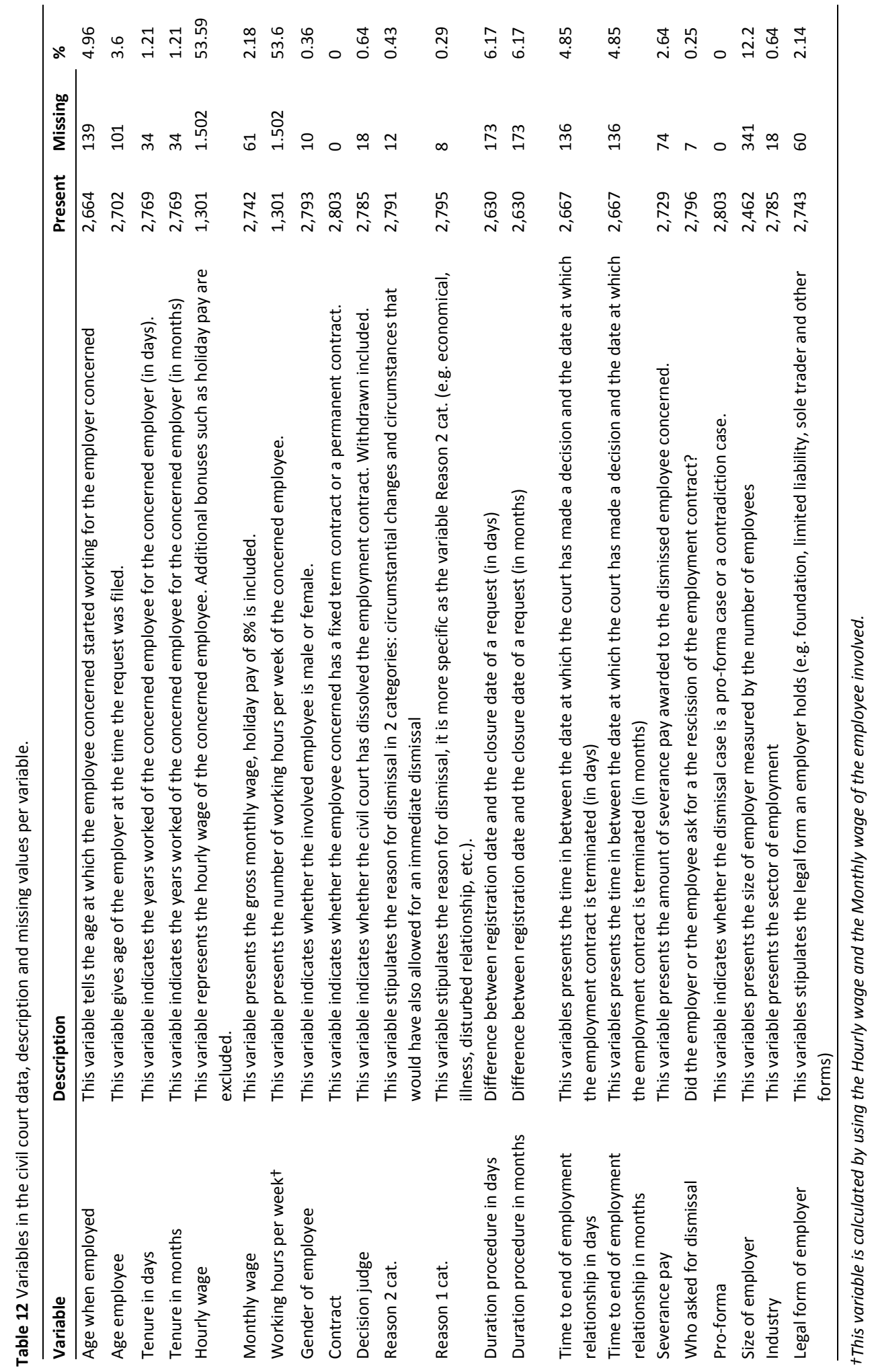


Table 13 Dismissal though PES or civil court: temporary contracts, plaintiff and year.

\begin{tabular}{lcc}
\hline PES (2006-2009) & $\mathbf{n}$ & \% \\
\hline Temporary contracts & 28 & 2.41 \\
Permanent contracts & 1,134 & 97.59 \\
Total & 1,162 & 100 \\
\hline Civil court (2003-2009) & $\mathbf{n}$ & $\%$ \\
\hline Temporary contracts & 106 & 4.44 \\
Permanent contracts & 2,284 & 95.56 \\
Total & 2,390 & 100 \\
\hline Civil court (2003-2009) & $\mathbf{n}$ & $\%$ \\
\hline Plaintiff is employee & 27 & 1.18 \\
Plaintiff is employer & 2,257 & 98.82 \\
Total & 2,284 & 100 \\
\hline Civil court (2003-2009) & $\mathbf{n}$ & $\%$ \\
\hline 2003-2005 & 1315 & 58.26 \\
2006-2009 & 942 & 41.74 \\
Total & 2,257 & 100 \\
\hline
\end{tabular}



CHAPTER 4:

FIRING COSTS 


\subsection{Introduction}

Under Dutch law, dismissal protection is regulated by an a priori control of dismissal. In this system, a Dutch employer can either request the civil court for a rescission of the employment contract or he may ask the public employment service $(P E S)^{119}$ for a dismissal permission. Termination by dismissal induces certain costs, which are different for both procedures. On average, the civil court is the faster and more expensive procedure. Termination of the contract is possible at short notice as legal notice periods may be ignored by the judge. The severance pay that is often awarded results in an increase in firing costs especially when long-tenured workers are dismissed. The likelihood that dismissal permission is given is high. The PES procedure is a less costly procedure, mainly because severance pay is not awarded. However, the procedure itself may take longer and the employer is bound to observe a notice period. Furthermore, the likelihood that dismissal is granted is smaller.

Following the European political debate about "labor market flexibility" in which the general perception holds that strict employment protection legislation (EPL) ${ }^{120}$ contributed to the inability of European labor markets to adapt to new conditions, Dutch EPL has received a considerable amount of criticism. According to the OECD-index, the Netherlands offers one of the most stringent provisions for permanent contracts (OECD, 2004). The overall intent of this index is to reflect the cost implications of various labor laws for employers. In other words, Dutch EPL regarding permanent contracts is characterized as costly. However, little information on the actual costs of a dismissal process exists. Previously, Hassink et al. (1998) estimated firing costs of both procedures. The authors used data gathered with the AVO-questionnaire (Arbeidsvoorwaarden Onderzoek), which contains information on the tenure, age and salary of a sample of Dutch workers. Using this information and estimated averages of procedural costs and the length of the procedure at both procedures, average dismissal costs for both procedures are calculated. Actual costs via the civil court and the PES are, however, not observed. The same holds true for the research conducted by Knegt and Tros (2007), commissioned by the Dutch government. Both analyses find that the civil court procedure is the most expensive procedure.

The purpose of this chapter is to calculate the actual dismissal costs of a dismissal procedure via the PES and via the civil court and to find out how they are different. To accomplish this, a selection of our unique dataset containing information of 878 and 994 individual dismissal cases brought to civil court and the PES, respectively, will be used. The main research question of this paper is the following: What are the costs of a dismissal procedure via the PES and of a dismissal procedure via the civil court and how do these costs differ?

After we shortly introduce the Dutch legislative system with respect to the termination of employment in Section 2, an overview of important literature on EPL is given in Section 3. Section 4 continues with a theoretical overview of costs and explains how cost components of both routes are different. In Section 5, we use a unique data set and highlight some specific examples from this data set. We show that costs of individual dismissal cases involving

\footnotetext{
${ }^{119}$ In this chapter PES is used as an acronym for public employment service. The official Dutch name for the PES is Uitvoerings Instituut Werknemersverzekering (UWV). In this dissertation, if we refer to the PES, we mean the UWV, and in particular the legal department of UWV that is responsible for handling dismissal requests.

${ }^{120} \mathrm{EPL}$ is used as an acronym for employment protection legislation
} 
employees that earn median wages may differ to a large extent. Differences in costs are found due to differences in the duration of the dismissal procedures, differences in notice periods and differences in severance payments. We also show that costs of the civil court procedure do not always outwit the cost of the PES procedure. In terms of average dismissal costs for both routes, we show that the civil court average is approximately 4 times the PES average. Median costs are twice as large. Furthermore, the standard deviation of the firing costs through the civil court is 10 times larger than for the PES. We also show that the differences in costs for both routes differ per reason of dismissal and for different employee and employer related characteristics. We must note that the decision of an employer to choose the one or the other route is a strategic decision, the particular route with the lowest expected cost is chosen. For some employers the civil court is the least expensive route. For other employers this holds true for the PES route of dismissal. As such, it is a different selection of employers and cases that turns to court or to the PES. Last, Section 6 concludes.

\subsection{Legislation}

Employees in the Netherlands are protected against dismissal via an a priori control of dismissal. An employer may either request the PES for a permission of dismissal (sec. 6 Extraordinary Labor Relations Decree) or he may ask the civil court for a dissolution of the employment contract (sec. 7:685 Civil Code (CC)). ${ }^{121}$ This section gives a short description of these two possibilities to terminate a permanent employment contract in the Netherlands.

PES. In order to terminate an employment contract, the employer needs prior approval of the PES. This is recorded in the Extraordinary Labor Relations Decree (ELRD), sec. 6. The PES operates under close supervision of the government. The minister of Social Affairs and Employment is authorized to grant dismissal approval and has delegated this authority to the PES. The PES is supposed to report to the Minister on how the authority to grant dismissal approval is practiced. Rules governing the dismissal approval are set by the Minister.

Prior approval is not needed for employees in the public service ${ }^{122}$, for dismissal during the probationary period, dismissal on grounds of an urgent case and dismissal as a result of the employer's bankruptcy. After having received an employer's application for dismissal and after having obtained the advice of a Redundancy Committee ${ }^{123}$ which is composed of representatives of the workers' and the employers' associations, the PES will reach a decision. Permission is given if dismissal is judged to be fair. Fair dismissals are dismissals based on economic grounds (e.g redundancy), dysfunctional behavior, a disturbed employment relationship, illness and misconduct. ${ }^{124}$ Yet, after having obtained approval, it is not the PES but the employer who terminates the employment contract. The employer may also decide not to use the permission.

\footnotetext{
${ }^{121}$ Next to termination by dismissal, an employment contract may also be terminated by mutual consent and by the expiration of a fixed term contract, on the expiration of an agreed upon period. Other options are termination of the contract during the trial period and summary dismissal. These options are not covered by our data.

${ }^{122}$ 1)Employees of a public body; 2) persons in an ecclesiastical position; 3) the teaching staff of educational institutes led by a natural person or body corporate; 4) employees only or predominantly performing domestic work in private households for less than three days a week and 5) statutory directors.

${ }^{123}$ In Dutch: Ontslagadviescommissie.

${ }^{124}$ See the different grounds for dismissal in section 4 and section 5 of the Dismissal Decree.
} 
Under Dutch law, termination of an employment relationship is unlawful when the statutory notice period is not observed. After prior approval of the PES, the applicable statutory notice period may be reduced with one month, provided that the notice period will be at least one month. Statutory minimum periods of notice (PoN) are presented in Table 1 below. Moreover, notice of termination must take effect at the end of a calendar month. ${ }^{125}$ To give an example, if prior approval of the PES is obtained on the $15^{\text {th }}$ of March and the employer decides to use the dismissal permit immediately, the period of notice takes effect April $1^{\text {st }}$. Once given, the dismissal approval is time-limited. This implies that the employer needs to terminate the contract before the expiry date of the permit. It is not possible to make an appeal against the decision of the PES. The employee, however, may file a protest against the decision of the PES at the civil court. In a repressive check, the judge may decide that the employee is compensated for the termination of his or her employment contract. ${ }^{126}$

Table 1 Periods of notice: statutory minimum and after approval of the PES.

\begin{tabular}{lll}
\hline Years of service & Statutory minimum PoN & PoN after approval of the PES \\
\hline Less than 5 year & 1 month & 1 month \\
5 to 10 years & 2 month & 1 month \\
10 to 15 years & 3 months & 2 months \\
More than 15 years & 4 months & 3 months \\
\hline
\end{tabular}

Dismissals based on economic grounds have to follow the "last in, first out" and the principle of reflection (see also Chapter 2). Together, these principles state that dismissal should be a function of age and tenure. A collective dismissal is a dismissal where the employer intents to dismiss at least 20 employees that are working within the same working district of the PES, and within a time frame of three months. If such is the case, the employer needs to follow the rules of the Collective Redundancy Notification Act (CRNA), which stipulates that employers have the obligation to notify the PES and all workers' organizations involved of termination dates, of specific details about the employees who are likely to be made redundant, and of the date on which the Works Council has been consulted. The PES does not assess the dismissal until one month after the application is received. During this month, the employer shall assess whether, and to which extent, job loss can be prevented. ${ }^{127}$ Moreover, a social plan is developed.

The PES procedure is a procedure in writing. In general, parties do not appear in front of the PES. An unjust termination of the employment contract without prior approval of the PES may be declared annul. ${ }^{128}$

Civil court. Rules and regulations regarding the rescission of the employment contract by court are recorded in the Civil Code. ${ }^{129}$ This route of termination via judicial decision is predominantly used by employers, but employees may also follow this procedure.

\footnotetext{
${ }^{125}$ Unless agreed otherwise in writing or determined by custom.

${ }^{126}$ Either the employee is awarded a severance payment that compensates for the losses that the employee incurs due to his or her dismissal, or the judge may decide that the employee is again employed by the employer.

${ }^{127}$ This waiting period does not hold when a declaration is submitted in which all concerned involved parties declare that they have been notified and that they agree with the situation.

${ }^{128}$ This implies that the employment contract is continued.

129 The provisions of the Civil Code do not apply to persons employed by a public body, unless agreed-upon otherwise by both parties, before or on initiation of the employment relationship, either by law or by ordinance.
} 
The civil court may dissolve the contract for substantial reasons. A substantial reason is a circumstance that would have also allowed for an immediate dismissal. Examples are fraud, incompetence, drunkenness, theft and reckless behavior. A substantial reason also refers to a circumstantial change that justifies the termination of an employment relationship. Examples are financial distress, disturbed employment relationship, and employee dysfunctional behavior. If an employment contract is rescinded because of a change in circumstances, the civil court may oblige the employer to pay severance payment.

The civil court procedure commences with an appeal motivating the termination of the employment contract. We can distinguish between two types of dismissal cases. The first type of case is the pro-forma case. In a pro-forma case, the employer and the employee have reached an agreement on the termination of employment. The employer submits a pro-forma request and the employee a pro-forma defense, which were harmonized in the negotiations. An oral hearing is not held. Generally, the court's verdict is in line with the agreements made by both parties. The second type of case is the contradiction case. In this type of case, the employer and the employee disagree about the terms of dismissal. When the civil court receives a request of the second type, both parties are heard during an oral session.

Unlike the PES, the civil court is not bound to observe the statutory notice period. It is not possible to make an appeal to the decision of the judge.

\subsection{Literature on EPL}

Employment protection legislation (EPL) was introduced to enhance workers' welfare and to improve employment conditions. However, that same legislation also translates into a cost for employers. If economists discuss EPL, they discuss the effects imposed by the set of laws on employment relationships on the working of the labor market (e.g. Emerson (1988); Lazear (1990); Autor, Donohue III \& Schwab (2006)). In this discussion, the costs that employers incur due to EPL are used as a reflection of the strictness of these set of laws (e.g. more costly is interpreted as more strict)).

Even though the European political arena seems to agree about the negative effects of EPL on different labor market outcomes, among economists there is a lot of controversy about the effect of EPL. We have shown in Chapter 2 of this dissertation that we do not know exactly what is the effect of EPL on different labor market outcomes. We refer to the overviews of Addison and Teixeira (2003) and the OECD (2004) to understand how many different conclusions are drawn. Although most studies use a measure that quantifies EPL in terms of costs, the way in which these costs are measured differs across studies.

Some macro studies use the severance pay and notice periods as a measure for EPL strictness. Drawing data from 22 countries over a period of 29 years, Lazear (1990) finds that an increase of no required severance pay to a required severance pay of three months would result in a decrease in the employment-population-ratio of 1 percent. Lazear furthermore finds that obliged severance pay results in an increase in unemployment rates. Results however, are not completely consistent. Drawing from the same sample of countries ${ }^{130}$, Addisson and Grosso (1996) revise the study of Lazear and find no evidence that severance pay increases

\footnotetext{
${ }^{130}$ The sample is similar in one exception; data on Portugal was dropped and on Finland was included.
} 
unemployment. Also, in contrast to the study of Lazear, Addisson and Grosso find that longer notice periods lead to positive effects on employment and unemployment. Other macro-studies use the OECD EPL-index (e.g. Nickell (1997)) or the existence of certain labor market institutions (LMI) as a measure of EPL strictness. In an empirical analysis, and using a sample of 17 OECD countries over the period 1960-1999, Belot and Van Ours (2004) show that certain combinations of LMI result in low unemployment rates. Other studies, such as the study of Di Tella and MacCulloch (2005) use self- reported measures of labor market flexibility. Using a data set covering 21 OECD countries over the period 1984-1990 that consists of surveys that were conducted amongst economic leaders and CEO's, Di Tella and MacCulloch suggest that labor market flexibility has a positive effect on employment and on the participation rate.

In micro studies, the effect of an EPL reform or the introduction of a new law is often analyzed. In a American based micro study, Oyer and Schaefer (2000) use the introduction of the Civil Rights Act of 1991 (CRA91), a law which affected the relative costs of individual dismissal suits, as their treatment effect. They argue that when an employee is more likely to file a suit against his employer when being individually dismissed than when being collectively dismissed as a part of a layoff, then a change in law that increases the expected costs of an individual lawsuit would cause firms to substitute away from individual firing towards mass layoff. In their focus on HR decisions made by the firm, Oyer and Schaefer's analysis departs from a large amount of studies that study the relation between EPL and labor market outcomes. See for instance DeLeire (2000) who analyzes the Americans with Disabilities Act (ADA) and its relation to the employment and wage of protected workers. DeLeire finds that an increase in protection due to ADA, which resulted in an increase in hiring and firing costs for employers, lead to 7.2 percentage points decrease in the employment of men with disabilities. Wages were not affected by ADA. Acemoglu and Angrist (2001) also investigated the effect of ADA and report results similar to the results of DeLeire. Furthermore, Autor, Donohue III and Schwab (2006) examine the effect of the employment-at-will doctrine in the United States and show that one wrongful-discharge doctrine, which resulted in an increase in firing costs and procedural inconveniences for employers, reduced state employment rates by $0.8 \%$ to $1.7 \%$.

Other micro-studies use company data and investigate the effect of firing costs on unemployment. See for example Pfann (2006) who uses personnel data of airplane manufacturer Fokker to develop a model that predicts how firing thresholds depend on the characteristics of individual workers. He finds a strong positive significant effect of firing costs on the possibility that a worker is rehired by the bankrupt trustees in charge of creating a new firm out of the bankrupt firm. Because firing costs depend on wages, for employees with similar characteristics, the employee with the highest wage has the lowest chance of being fired. In an Italian setting, Boeri and Jimeno (2005) exploit the fact that firms in Italy below a certain sizethreshold are not covered by the most restrictive EPL provisions. They find that employees with permanent contracts in firms exposed to less restrictive EPL are more likely to be fired. Also in an Italian setting, Kugler and Pica (2008) study the effect of an Italian reform in 1990 that lead to an increase in dismissal costs for business below 15 employees, while dismissal costs for larger firms stayed constant. Their results suggest that the increase in dismissal costs had a negligible effect on net employment. The reform moreover led to reduced entry rates and employment adjustments. Different from Boeri and Jimeno, who exploited the variation of EPL across small and large firms. Kugler and Pica fully exploited both cross sectional and temporal variation in EPL. 
Although the Dutch discussion about EPL is a discussion about costs, we do not exactly know the costs of a Dutch dismissal procedure. The studies of Hassink et al.(1998) and Knegt and Tros (2007) calculate the average costs of dismissal for both the PES and the civil court procedure but have, as mentioned in the introduction, some potential drawbacks. Furthermore, they are outdated. In order to gain more insight into the Dutch situation, an overview of dismissal costs that is up-to date and that goes beyond the calculation of averages is needed.

\subsection{Theoretical overview of costs}

The costs that arise from a PES procedure or a civil court procedure are different. When following a dismissal procedure via the PES, the employer incurs the costs of ongoing wage payment to the employee during the duration of dismissal. When following a dismissal procedure via the civil court the employer incurs the costs of a court fee, the costs of ongoing wage payment to the employee during the duration of dismissal and the costs of a severance payment that is paid to the employee when he or she is dismissed. This section will describe the above mentioned costs in more detail. Figure 1 gives an overview of these costs. ${ }^{131}$

PES. When an employer follows the PES procedure of dismissal, he will incur the ongoing wage costs that are made during the duration of the dismissal. The duration of dismissal can be broken down into three components: 1) the duration of the PES procedure, 2) the time to notice and 3 ) the period of notice. The first component, the duration of the PES procedure, is the actual time the PES needs to reach a decision. It commences the moment a request is registered and it ends the moment the PES grants dismissal permission. The second component, the time to notice, equals the time in between the moment dismissal permission is granted and the moment the period of notice commences. The third duration component of dismissal, the period of notice, is solely determined by the number of years of service of the employee, and is recorded in the Civil Code of law (see Table 1). ${ }^{132}$

We shall illustrate the above with an example. Consider a specific dismissal case in which the dismissal procedure is initiated at the $1^{\text {st }}$ of March and dismissal permission is granted by the PES at the $15^{\text {th }}$ of March. The employee involved worked for his employer for 4 years and earns a gross monthly salary of $€ 2,000$, including a holiday payment. For this specific case the duration of the PES dismissal procedure equals $1 / 2$ months (from the $1^{\text {st }}$ of March until the $15^{\text {th }}$ of March). Approval may be granted the $15^{\text {th }}$ of March, yet, the period of notice does not take effect until the $1^{\text {st }}$ of $A$ pril ${ }^{133}$. In this specific case, the duration of the time to notice equals $1 / 2$ months (from the $16^{\text {th }}$ of March until the $31^{\text {th }}$ of March). Because the employee was employed for 4 years, the official period of notice equals 1 months (from the $1^{\text {st }}$ of April until the $30^{\text {th }}$ of April). The total duration of dismissal equals 2 months $(1 / 2$ months $+1 / 2$ months +1 month) and costs incurred are 2 times the monthly salary of $€ 2,000$.

Civil court. Before commencing a procedure at the civil court, the employer is obliged to pay a court fee. This fee is dependent upon the legal form of the employer. Legal forms that do

\footnotetext{
${ }^{131}$ With respect to the wage costs that are made during the duration of dismissal, we make the assumption that workers are not productive during this period.

${ }^{132}$ As mentioned before, when terminating an employment contract after receiving a dismissal permission of the PES the legal period of notice needs to be respected.

${ }^{133}$ By law, the notice period commences at the first day of a calendar month, unless agreed upon otherwise.
} 
not involve a legal person are charged $€ 106$. Legal forms that do involve a legal person are charged $€ 71$ (www.rechtspraak.nl, 2009. ${ }^{134,135,136}$ Furthermore, the employer will incur costs of the ongoing wage payments that are made to the employee during the duration of the dismissal. At the civil court, the duration of dismissal can be broken down into two components. 1) the duration of the civil court procedure and 2) the time in between the date the civil court reaches a verdict and the date the employment contract is terminated. The first component of the dismissal duration, the duration of the civil court procedure, is the time the court needs to reach a decision. It commences the moment a request is registered until the moment the court reaches a verdict. The second component of the dismissal duration, the time in between the date the civil court reaches a verdict and the date the employment contract is terminated is determined by the court. A court is not bound to observe the statutory notice period, and decides when the employment contracted is dissolved. A last cost that is incurred by employers when following the civil court procedure is the cost of a severance payment, which is paid to the dismissed employee. The height of this payment is stated in a civil court guideline and equals $A x$ $B \times C$, where factor $A$ is the weighted years of service. The older the employee, the more weight is attached to his or her years of service (see Table 2). Factor $B$ is the gross monthly salary and factor $C$ is a correction factor that is determined by the civil court.

We shall illustrate the above with an example. Consider a specific dismissal case that is initiated at the $1^{\text {st }}$ of March. The employer involved holds a limited liability private company (BV) As such, his court fee equals $€ 106$. The employee involved earns a gross monthly salary of $€ 2,000$, including a holiday payment. The court delivers its judgment at the $15^{\text {th }}$ of March and decides that the employment contract of the involved employee is dissolved at the $31^{\text {th }}$ of March. This given, the duration of the civil court procedure equals $1 / 2$ months (from the 1 st of March until the $15^{\text {th }}$ of March), and the duration of the time in between the date the civil court reaches a verdict and the date the employment contract is dissolved equals $1 / 2$ months (from the $15^{\text {st }}$ of March until the $31^{\text {th }}$ of March). The court verdicts the employer to award the employee a severance payment of $€ 20.000$. The total costs in this specific case equal the sum of the court fee, one monthly salary and the severance payment, which are $€ 106, € 2,000$ and $€ 20,000$, respectively. Costs thus equal $€ 22,106$.

\footnotetext{
${ }^{134}$ Retrieved December $15^{\text {th }} 2009$.

135 Legal forms that do not involve a legal person are: Sole traders, Commanditaire vennootschap (CV) or limited partnership and Maatschap or partnership. Legal forms that do involve a legal person are: Besloten Vennootschap (BV) or limited liability private company, Vereniging or association and Stichting or foundation. VOF's are also charged a fee of $€ 106$.

${ }^{136}$ Another cost that may arise when following the PES or the civil court procedure, is the cost of legal support. These costs are not covered by this paper. Additionally, when reaching a verdict, the civil court may oblige the employer to reimburse employees for the legal expenses incurred. In some cases, employees are sentenced to reimburse employers. Again, these costs are not taken into account in this paper, because with respect to total costs in our data these costs are negligible. The PES does not address reimbursement of legal expenses.
} 
Table 2 Factor A of the civil court formula.

\begin{tabular}{llll}
\hline Before January 1st 2009 & \multicolumn{2}{l}{ After January 1st 2009 } \\
\hline Years of service & Factor A & Years of service & Factor A \\
$<40$ years & 1 & $<35$ years & 0.5 \\
$40-50$ years & 1.5 & $35-45$ years & 1 \\
$>50$ years & 2 & $45-55$ years & 1,5 \\
& & $>55$ years & 2 \\
\hline
\end{tabular}

\begin{tabular}{|c|c|c|c|c|}
\hline & 1.Procedurd costs & 2. Woge costs durin & the process of dismissol & 3.Severonce poy \\
\hline PES & $\begin{array}{l}\text { No procedural } \\
\text { costs }\end{array}$ & $\begin{array}{l}\text { Duration of PES } \\
\text { procedure }\end{array}$ & $\begin{array}{l}\text { Period of } \\
\text { notice }\end{array}$ & $\begin{array}{l}\text { No severance } \\
\text { pay }\end{array}$ \\
\hline $\begin{array}{l}\text { Cull } \\
\text { court }\end{array}$ & Court fee & $\begin{array}{l}\text { Duration of civil court } \\
\text { procedure }\end{array}$ & $\begin{array}{l}\text { Time to termination of the } \\
\text { employment relationship }\end{array}$ & Severance pay \\
\hline
\end{tabular}

Figure 1 Observed costs of dismissal.

\subsection{Data}

In order to calculate the firing costs per procedure, we only selected cases in which the PES has granted dismissal permission and the civil court has dissolved the employment contract. For matters of comparability, we furthermore selected cases that were closed in the period 20062009. As such, the sample used in this chapter contains 994 PES cases and 878 civil court cases. ${ }^{137}$ Figure 2 presents an overview of the data in terms of the number of requests closed per month. It shows that the number of dismissal cases closed at the PES and at the civil court are approximately equal until 2009. Furthermore, the pattern at PES is a more cyclical pattern. Peaks are shown every other fourth month.

Six different dismissal cases in the data ${ }^{138}$

This section discusses six dismissal cases, of which three are filed the PES and three are filed at the civil court. The six examples are all about median wage workers. The examples show, however, that dismissal costs can vary widely. All examples are presented in Table 3.

PES. Worker 1 , age 40 , male, earns a gross monthly salary of $€ 2,264$, including a holiday pay of $8 \%$ of the gross yearly salary. The reason for his dismissal is an economic ground. His employer is a limited liability private company (BV). Worker 1 worked 6 years under a permanent employment contract. As such, the legal period of notice equals one month. The dismissal procedure is initiated at the PES in February 2006. The employment contract is terminated at the end of March 2006. The total duration of the dismissal, including the duration of the PES procedure, the time to notice and the period of notice equals 1.2 months. Because

\footnotetext{
${ }^{137} 2$ cases civil court cases were only partly dissolved. These are excluded.

${ }^{138}$ All amounts presented are in 2006 constant prices. That is why the court fee does not always precisely equal $€ 106$ or $€ 71$.
} 
the PES does not ask for a procedural fee, nor does it impose the employer to pay severance payment, total dismissal costs equal 1.2 months times the gross monthly wage, which comes down to $€ 2,271(1.2 \times € 2,264)$.

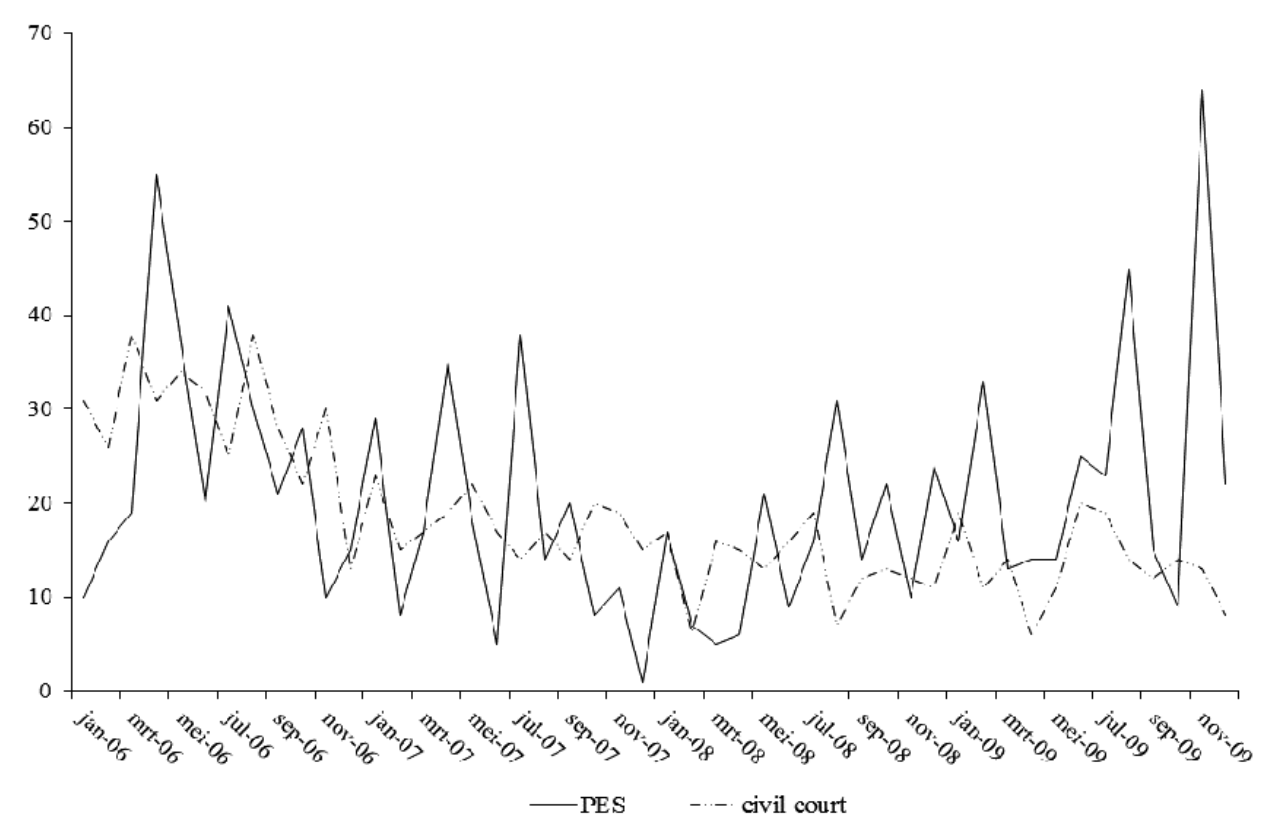

Figure 2 Number of dismissal files per month. Registered date: closure of the procedure (2006-2009).

Worker 2, age 44 , female, earns a gross monthly salary of $€ 2,002$, including a holiday pay of $8 \%$ of the gross yearly salary. The reason for her dismissal is an economic ground. Her employer is a limited liability private company (BV). Worker 2 worked 17 years under a permanent employment contract. As such, the legal period of notice equals 3 months. The dismissal procedure is initiated at the PES in January 2008. The employment contract is terminated at the end of April 2008. The total duration of the dismissal, including the duration of the PES procedure, the time to notice and period of notice equals 3.5 months. The total dismissal costs equal 3.5 months times the gross monthly wage, which comes down to $€ 6,694(3.5 \times € 2,002)$.

Worker 3 , age 57 , female, earns a gross monthly salary of $€ 2,682$, including a holiday pay of $8 \%$ of the gross yearly salary. The reason for her dismissal is a disturbed relationship. Her employer is a limited liability private company (BV). Worker 3 worked 24 years under a permanent employment contract. As such, the legal period of notice equals 3 months. The dismissal procedure is initiated at the PES in October 2008. The employment contract is terminated at the end of April 2009. The total duration of the dismissal, including the duration of the PES procedure, the time to notice and period of notice equals 6,8 months. The total dismissal costs equal 6.8 months times the gross monthly wage, which comes down to $€ 18,185$ $(6.8 \times € 2,682)$.

Civil court. Worker 4, age 33, male, earns a gross monthly salary of $€ 2,240$, including a holiday pay of $8 \%$ of the gross yearly salary. Worker 4 worked for 2 years under a permanent employment contract. His employer holds a limited liability private company (BV). The court fee 
equals $€ 102$. His employer intended to dissolve the contract because of a disturbed relationship. The procedure is a pro-forma procedure. It is initiated in March 2008 and has a duration of 3 days. The civil court decides that the employment contract is terminated one day later. As such, the total duration of the dismissal is 0.13 months. Moreover, the court does not impose severance payment on the employer. Total costs of the dismissal equal the sum of the court fee and 0.13 months times the monthly wage. This is equal to $€ 499(€ 102+(0.13 \times € 2,240))$.

Worker 5 , age 34 , female, earns a gross monthly salary of $€ 2,343$, including a holiday pay of $8 \%$ of the gross yearly salary. Worker 5 worked for 9 years under a permanent employment contract. Her employer holds a limited liability private company (BV). The court fee equals $€ 101$. Her employer intended to dissolve the contract because of a disturbed relationship. The procedure is a pro-forma procedure. It is initiated in August 2009 and has a duration of one day. The court decides that the employment contract is terminated 50 days later. As such, the total duration of the dismissal is 1.7 months. Moreover, the court imposes a severance payment of $€ 9,521$ on the employer. Total costs of the dismissal equal the sum of the court fee, 1,7 months times the monthly wage and the severance payment. This is equal to $€ 13,628$ (€101 $+(1.7 x$ $€ 2,343)+€ 9,521)$.

Worker 6 , age 50 , male, earns a gross monthly salary of $€ 2,161$, including a holiday pay of $8 \%$ of the gross yearly salary. Worker 6 worked for 11 years under a permanent employment contract. His employer holds a limited liability private company (BV). The court fee equals $€ 107$. His employer intended to dissolve the contract because of economic reasons. The procedure is not a pro-forma procedure. It is initiated in May 2007 and has a duration of 23 days and 5 months. The court decides that the employment contract is terminated one day later. As such, the total duration of the dismissal is 5.8 months. Moreover, the court imposes a severance payment of $€ 50,456$ on the employer. Total costs of the dismissal equal the sum of the court fee, 5.8 months times the monthly wage and the severance payment. This is equal to $€ 63,132$ $(€ 107+(5.8 \times € 2,161)+€ 50,456)$.

The overview in Table 3 shows that in these six cases civil court procedures are not always more expensive than PES procedures. In fact, the costs of dismissal for worker 4 are the lowest of all examples presented. Would worker 4 have been fired via the PES, costs would have equaled 1 monthly salary at least due to the obligatory period of notice of one month. 
Table 3 Six different workers and calculation of total dismissal costs (close to median wages, different costs)*.

\begin{tabular}{|c|c|c|c|}
\hline & Worker 1 & Worker 2 & Worker 3 \\
\hline Age & 40 & 44 & 57 \\
\hline Tenure & 6 years & 17 years & 24 years \\
\hline Reason for dismissal & Economical & Economical & Disturbed relationship \\
\hline Institute & PES & PES & PES \\
\hline Procedural fee & $€ 0$ & $€ 0$ & $€ 0$ \\
\hline \multirow[t]{4}{*}{$\begin{array}{l}\text { Ongoing wage payment during } \\
\text { duration of dismissal }\end{array}$} & $\begin{array}{l}\text { Total duration: } \\
1.2 \text { months }\end{array}$ & $\begin{array}{l}\text { Total duration: } \\
3.5 \text { months }\end{array}$ & $\begin{array}{l}\text { Total duration: } \\
6.8 \text { months }\end{array}$ \\
\hline & Wage payment & Wage payment & Wage payment \\
\hline & $1.2 x € 2,264$ & $3.5 x € 2,002$ & $6.8 x € 2,682$ \\
\hline & $=€ 2,711$ & $=€ 6,694$ & $=€ 18,185$ \\
\hline Severance pay & $€ 0$ & $€ 0$ & $€ 0$ \\
\hline \multirow[t]{2}{*}{ Total costs } & $€ 2,711$ & $€ 6,694$ & $€ 18,185$ \\
\hline & Worker 4 & Worker 5 & Worker 6 \\
\hline Age & 33 & 34 & 50 \\
\hline Tenure & 2 years & 9 years & 11 years \\
\hline Reason for dismissal & Disturbed relationship & Disturbed relationship & Economical \\
\hline Pro-forma & Pro-forma & Pro-forma & Non pro-forma \\
\hline Institute & Civil court & Civil court & Civil court \\
\hline Procedural fee & $€ 102$ & $€ 101$ & $€ 107$ \\
\hline \multirow[t]{4}{*}{$\begin{array}{l}\text { Ongoing Wage payment during } \\
\text { duration of dismissal }\end{array}$} & $\begin{array}{l}\text { Total duration: } \\
4 \text { days }\end{array}$ & $\begin{array}{l}\text { Total duration: } \\
1.7 \text { months }\end{array}$ & $\begin{array}{l}\text { Total duration: } \\
58 \text { months }\end{array}$ \\
\hline & Wage payment & Wage payment & Wage payment \\
\hline & $0.13 x € 2,240$ & $1.7 x € 2,343$ & $5.8 \times € 2,161$ \\
\hline & $=€ 397$ & $=€ 4,006$ & $=€ 12,573$ \\
\hline Severance pay & $€ 0$ & $€ 9,521$ & $€ 50,456$ \\
\hline Total costs & $€ 499$ & $€ 13,628$ & $€ 63,132$ \\
\hline
\end{tabular}

*All costs are in 2006 constant prices.

\section{Variables in the data}

Table 4a presents descriptive statistics of the duration of dismissal. Additionally, for the civil court procedure descriptive statistics of the court fee and the severance payment are given. The total duration of the dismissal at the PES is the sum of the duration of the actual PES procedure, the time to notice and the period of notice (column $2+3+4) .{ }^{139}$ The average total duration equals 3.5 months, the minimum total duration equals 1.03 months and the maximum duration

\footnotetext{
139 The duration of the procedure we report is slightly longer than the one reported by the PES. We took the difference between the closure date and the registration date of the request. The PES calculates the duration of the procedure by taking the difference between the closure date and the date the request is taken into account. We also calculated the duration of the civil court process as the difference between the closure date and the date of registration, as such durations of both procedure are comparable. With respect to wage, for both procedures we calculated the gross wage including an $8 \%$ holiday payment. We did not include additional fees, such as bonuses. These additional fees are only known for the civil court observations. We made this decision because the main goal of this paper is to compare the costs of both procedures.
} 
over a year. ${ }^{140}$ With an average of 1.72 months, the period of notice has the longest duration, followed by the duration of the PES procedure ( 1.39 months) and the time to notice $(0.39$ months).

For the civil court, the total duration of the dismissal is the sum of the duration of the actual civil court procedure and the time in between the date the civil court reaches a verdict and date the employment contract ends (column $2+3$ ). With 1.5 months, the average total duration of dismissal is less than half the length of the average total duration of dismissal at the PES. The duration of the actual civil court procedure equals 0.29 months, the duration of the time to termination is longer (1.24 months). The average court fee equals $€ 102$, average severance payments are $€ 26,619$. Table $4 \mathrm{~b}$ presents other continuous variables that are present in the dataset. It shows that workers who are dismissed via the PES procedure have longer tenure than workers who are dismissed via the civil court. Additionally, workers that are dismissed via the PES procedure are slightly older and their salary, expressed in both monthly salary and hourly wage, is lower. Table $4 \mathrm{c}$ shows the descriptive statistics of the categorical variables that are present in the dataset. It shows that employers turn to civil court and the PES for different reasons of dismissal. PES mainly processes dismissal cases due to economic reasons (73 percent of total) and prolonged illness (25 percent of total). Of all economic cases, 28 percent is of a collective nature. At the civil court the majority of cases is filed due to a disturbed employment relationship or dysfunctional behavior ( 73 percent of total), followed by cases filed due to economic reasons ( 25 percent of total). Furthermore, 86 percent of all cases at civil court is pro-forma. The distribution of cases with respect to the industry in which the employer operates is not so different for both procedures. Larger differences in firm size are found. The majority of employers following the PES procedure employ between 10 and 100 employees, the majority of those filing a suit via the civil court are large employers, employing more than 100 people. Last, differences in the distribution of gender and legal form are small.

\section{Average dismissal costs}

Table 5 presents the average dismissal costs for all costs components of both the PES procedure and the civil court procedure. Figure $3 \mathrm{a}$ and Figure $3 \mathrm{~b}$ give a graphical representation of the average dismissal costs. Average dismissal costs are calculated as follows:

Average dismissal costs PES $=\frac{\sum_{i=1}^{n}\left(\left(A 1_{i}+A 2_{i}+A 3_{i}\right) \text { Salary }_{i}\right)}{n}$

, where $n$ equals 994. A1 refers to the duration of the PES procedure. A2 refers to the time to notice, and $\mathrm{A} 3$ to the period of notice. Salary is the gross monthly salary including a holiday payment of $8 \%$.

Average dismissal costs civil court $=\frac{\sum_{j=1}^{m}\left(\text { Court fee }_{j}+\left(\left(B 1_{j}+B 2_{j}\right) \text { Salary }_{j}\right)+\text { Severance pay }_{j}\right)}{m}$

\footnotetext{
${ }^{140}$ For all statistics related to time, the following rule applies:

Number of years $=$ (number of months) $/ 12$.

Number of months=(number of days/365) $\times 12$.
} 
, where m equals 878 . B1 refers to the duration of the civil court procedure, and B2 to the time in between the moment the court reaches a verdict and the moment the contract is terminated. Salary is the gross monthly salary including a holiday payment of $8 \%$.

Table 5 and Figure 3 a show that, on average, the PES procedure costs $€ 7,480$. The lowest costs incurred by an employer equal $€ 171$, the highest costs incurred equal $€ 61,714$. The largest costs component for employers that follow the PES procedure are the ongoing wage costs that are made during the period of notice. These costs equal $€ 3,728$. Moreover, the ongoing wage costs that are made during the duration of the PES procedure are $€ 2,964$. Ongoing wage costs during the time to notice are much smaller, namely €787. Figure 4a gives a graphical presentation of the distribution of total PES dismissal costs in our sample. It shows that the distribution of costs is not a symmetric distribution where the median and mean are equal (see also Table 5). Instead, it is skewed to the right. The distribution shows that 0.6 percent of all 994 dismissal cases cost less than $€ 500$ and that 0.1 percent of cases cost more than $€ 6,000$. The majority of cases cost between $€ 4,000$ and $€ 6,000$ (21.4 percent).

On average, the civil court procedure is more expensive than the PES procedure (Figure $3 \mathrm{~b}$, Table 5). Total dismissal costs add up to an average of $€ 30,982$. The median costs are $€ 13,708$ and are only twice as large as the median PES costs. The variance, however, is much larger. This is an important finding because it implies that the outcome in terms of costs is much more uncertain.

Court fees are a negligible share of total costs. The ongoing wage costs made during the duration of the civil court procedure equal $€ 765$ and are lower than the ongoing wage costs that are incurred by employers during the PES procedure. A good explanation for this difference is given by Table $4 \mathrm{a}$ and Table $4 \mathrm{~b}$. Although wages are generally higher for employees of employers that follow the civil court procedure, the duration of the actual procedure is shorter. As such, the outcome of the multiplication of duration and wage is lower for dismissals via civil court than for dismissals via the PES. 
Table 4a Descriptive statistics: continuous variables related to the costs of dismissal (2006-2009).

\begin{tabular}{|c|c|c|c|c|c|c|}
\hline column & 1 & 2 & 3 & 4 & 5 & 6 \\
\hline $\begin{array}{l}\text { PES, } \\
n=994\end{array}$ & Court fee * & $\begin{array}{l}\text { Duration of PES } \\
\text { procedure in } \\
\text { months** }\end{array}$ & $\begin{array}{l}\text { Time to notice in } \\
\text { months }\end{array}$ & $\begin{array}{l}\text { Period of notice } \\
\text { in months }\end{array}$ & $\begin{array}{c}\text { Total duration in } \\
\text { months } \\
\text { (column } 2+3+4 \text { ) }\end{array}$ & $\begin{array}{l}\text { Severance } \\
\text { payment * }\end{array}$ \\
\hline Mean & & 1.39 & .39 & 1.72 & 3.50 & \\
\hline Median & & 1.18 & .33 & 1.00 & 3.28 & \\
\hline Std. Dev. & & 1.09 & .26 & .88 & 1.44 & \\
\hline Minimum & & .00 & .03 & 1.00 & 1.03 & \\
\hline Maximum & & 10.82 & 1.02 & 3.00 & 12.90 & \\
\hline column & 1 & 2 & 3 & 4 & 5 & 6 \\
\hline $\begin{array}{l}\text { Civil Court, } \\
n=878\end{array}$ & Court fee * & $\begin{array}{l}\text { Duration of civil } \\
\text { court procedure } \\
\text { in months*** }\end{array}$ & $\begin{array}{l}\text { Time to } \\
\text { termination of } \\
\text { contract in } \\
\text { months }\end{array}$ & & $\begin{array}{l}\text { Total duration in } \\
\text { months } \\
\text { (column } 2+3 \text { ) }\end{array}$ & $\begin{array}{l}\text { Severance } \\
\text { payment } * \boldsymbol{\dagger}\end{array}$ \\
\hline Mean & $€ 102.46$ & .29 & 1.24 & & 1.53 & $€ 26,619$ \\
\hline Median & $€ 104.10$ & .10 & 1.05 & & 1.26 & $€ 10,159$ \\
\hline Std. Dev. & $€ 7.31$ & .60 & .95 & & 1.06 & $€ 52,370$ \\
\hline Minimum & $€ 66.83$ & .00 & .00 & & .00 & $€ 0$ \\
\hline Maximum & $€ 118.17$ & 9.47 & 3.58 & & 10.78 & $€ 664,174$ \\
\hline
\end{tabular}

*In 2000 constant prices.

**The duration of the procedure we report is slightly longer than the one reported by the PES. We took the difference between the closure date and the registration date of the request. The PES calculates the duration of the procedure by taking the difference between the closure date and the date the request is taken into account. We also calculated the duration of the civil court process as the difference between the closure date and the date of registration, as such durations of both procedure are comparable.

***In pro-forma cases at the civil court, a judge can make a decision at the same day the request is registered.This occurs in 10 percent of the cases. At the PES this occurs only very occasionally (0.6\%). In all of these dismissal cases the employee signed a "Declaration of no objection" (Werknemersverklaring van geen bezwaar), which allowed for a faster procedure.

+ Severance payments also include payments as stipulated in a social plan, payments that are awarded to supplement the unemployment benefit or to supplement retirement money.

Table 4b Descriptive statistics: continuous variables (2006-2009) (continued on the next page).

\begin{tabular}{lcccccc}
\hline $\begin{array}{l}\text { PES, } \\
\mathbf{n = 9 9 4}\end{array}$ & $\begin{array}{c}\text { Tenure in } \\
\text { months }\end{array}$ & $\begin{array}{c}\text { Age when in } \\
\text { employed }\end{array}$ & $\begin{array}{c}\text { Age at time of } \\
\text { process }\end{array}$ & $\begin{array}{c}\text { Gross monthly Hourly wage** Hours per week } \\
\text { wage* }\end{array}$ \\
\hline Mean & 129.90 & 33.62 & 44.45 & $€ 2,050$ & $€ 13.46$ & 31.79 \\
Median & 93.45 & 32.52 & 45.00 & $€ 2,003$ & $€ 12.35$ & 36.41 \\
Std. Dev. & 105.26 & 10.26 & 10.11 & $€ 1,106$ & $€ 5.22$ & 9.85 \\
Minimum & 1.64 & 15.59 & 17.00 & $€ 92$ & $€ 3.59$ & 2.13 \\
Maximum & 513.44 & 65.45 & 70.00 & $€ 12,640$ & $€ 69.25$ & 50.00 \\
\hline
\end{tabular}




\section{CHAPTER 4}

Table $4 \mathrm{~b}$ continued

\begin{tabular}{lcccccc}
\hline $\begin{array}{l}\text { Civil Court } \\
\mathbf{n = 8 7 8}\end{array}$ & $\begin{array}{c}\text { Tenure in } \\
\text { months }\end{array}$ & $\begin{array}{c}\text { Age when in } \\
\text { employed }\end{array}$ & $\begin{array}{c}\text { Age at time of } \\
\text { process }\end{array}$ & $\begin{array}{c}\text { Gross monthly } \\
\text { wage }\end{array}$ & Hourly wage Hours per week \\
\hline Mean & 119.47 & 32.26 & 42.21 & $€ 2,644$ & $€ 16.33$ & 33.35 \\
Median & 79.10 & 30.74 & 42.00 & $€ 2,247$ & $€ 14.02$ & 36.00 \\
Std. Dev. & 112.96 & 9.51 & 9.81 & $€ 1,748$ & $€ 8.56$ & 7.90 \\
Minimum & 1.12 & 15.16 & 19.00 & $€ 222$ & $€ 6.85$ & 4.85 \\
Maximum & 550.13 & 56.44 & 64.00 & $€ 17,129$ & $€ 86.64$ & 43.49 \\
\hline
\end{tabular}

* Including holiday payment, in 2000 constant prices.

** Excluding holiday payment, in 2000 constant prices.

Table 4c Descriptive statistics: categorical variables (2006-2009) (continued on the next page)

\begin{tabular}{|c|c|c|c|c|c|}
\hline \multicolumn{3}{|l|}{ PES } & \multicolumn{3}{|l|}{ Civil court } \\
\hline Reason for dismissal & $\mathbf{n}$ & $\%$ & Reason for dismissal & $\mathbf{n}$ & $\%$ \\
\hline Economical & 722 & 72.64 & Economical & 222 & 25.28 \\
\hline Dysfunctional† & 6 & 0.60 & Dysfunctional† & 642 & 73.12 \\
\hline Prolonged illness & 253 & 25.45 & Prolonged illness & 7 & 0.80 \\
\hline Other & 13 & 1.31 & Other & 7 & 0.80 \\
\hline Total & 994 & 100 & Total & 878 & 100 \\
\hline Collective or not & $\mathbf{n}$ & $\%$ & Pro-forma or not & $\mathbf{n}$ & $\%$ \\
\hline collective dismissal & 216 & 27.98 & Pro-forma cases & 753 & 85.76 \\
\hline Non-collective dismissals & 556 & 72.02 & Non-proforma cases & 125 & 14.24 \\
\hline Total & $772 *$ & 100 & Total & 878 & 100 \\
\hline Industry & $\mathbf{n}$ & $\%$ & Industry & $\mathbf{n}$ & $\%$ \\
\hline Agriculture and Forestry & 14 & 1.41 & Agriculture and Forestry & 4 & 0.46 \\
\hline Electricity, gas and water & 9 & 0.91 & Electricity. gas and water & 10 & 1.14 \\
\hline Industry & 303 & 30.48 & Industry & 238 & 27.11 \\
\hline Construction & 59 & 5.94 & Construction & 39 & 4.44 \\
\hline $\begin{array}{l}\text { Wholesale, trade, resale trade } \\
\text { and repairs }\end{array}$ & 215 & 21.63 & $\begin{array}{l}\text { Wholesale. trade. resale } \\
\text { trade and repairs }\end{array}$ & 117 & 13.33 \\
\hline Hotel and catering & 25 & 2.52 & Hotel and catering & 19 & 2.16 \\
\hline Transport, storage and & 61 & 6.14 & Transport. storage and & 87 & 9.91 \\
\hline Financial firms & 2 & 0.20 & Financial firms & 24 & 2.73 \\
\hline Commercial services & 119 & 11.97 & Commercial services & 163 & 18.56 \\
\hline Recruitment & 14 & 1.41 & Recruitment & 26 & 2.96 \\
\hline Governmental & 3 & 0.30 & Governmental & 8 & 0.91 \\
\hline Education & 3 & 0.30 & Education & 20 & 2.28 \\
\hline Health and wellness & 135 & 13.58 & Health and wellness & 92 & 10.48 \\
\hline Culture and recreation & 32 & 3.22 & Culture and recreation & 31 & 3.53 \\
\hline Total & 994 & 100 & Total & 878 & 100 \\
\hline
\end{tabular}

tDysfunctional behavior/disturbed relationship.

* Total refers to only dismissal cases due to economic reasons. 
Table 4c continued.

\begin{tabular}{|c|c|c|c|c|c|}
\hline Firm size & $\mathbf{n}$ & $\%$ & Firm size & $\mathbf{n}$ & $\%$ \\
\hline Less than 10 & 194 & 19.52 & Less than 10 & 134 & 15.26 \\
\hline Between 10-100 & 570 & 57.34 & Between 10-100 & 235 & 26.77 \\
\hline More than 100 & 230 & 23.14 & More than 100 & 509 & 57.97 \\
\hline Total & 994 & 100 & Total & 878 & 100 \\
\hline Gender & $\mathbf{n}$ & $\%$ & Gender & $\mathbf{n}$ & $\%$ \\
\hline female & 408 & 41.05 & female & 344 & 39.18 \\
\hline male & 586 & 58.95 & male & 534 & 60.82 \\
\hline Total & 994 & 100 & Total & 878 & 100 \\
\hline Legal form & $\mathbf{n}$ & $\%$ & Legal form & $\mathbf{n}$ & $\%$ \\
\hline Limited liability & 745 & 74.95 & Limited liability & 624 & 71.07 \\
\hline Foundation & 139 & 13.98 & Foundation & 108 & 12.30 \\
\hline Sole trader & 77 & 7.75 & Sole trader & 26 & 2.96 \\
\hline Other & 33 & 3.32 & Other & 120 & 13.67 \\
\hline Total & 994 & 100 & Total & 878 & 100 \\
\hline
\end{tabular}

* Total refers to only dismissal cases due to economic reasons

Table 5 Average costs of dismissalt.

\begin{tabular}{|c|c|c|c|c|c|c|}
\hline PES $n=994$ & Court fee & $\begin{array}{c}\text { Wage costs } \\
\text { duration of } \\
\text { process }\end{array}$ & $\begin{array}{l}\text { Wage costs time } \\
\text { to notice }\end{array}$ & $\begin{array}{c}\text { Wage costs } \\
\text { period of notice }\end{array}$ & & $\begin{array}{c}\text { Total dismissal } \\
\text { costs }\end{array}$ \\
\hline Mean & & $€ 2,964$ & $€ 787$ & $€ 3,728$ & & $€ 7,480$ \\
\hline Median & & $€ 2,347$ & $€ 583$ & $€ 2,458$ & & $€ 6,054$ \\
\hline Std. Dev. & & $€ 3,098$ & $€ 685$ & $€ 3,102$ & & $€ 5,648$ \\
\hline Min & & $€ 0$ & $€ 9$ & $€ 92$ & & $€ 171$ \\
\hline Max & & $€ 32,651$ & $€ 3,948$ & $€ 25,685$ & & $€ 61,714$ \\
\hline $\begin{array}{l}\text { Civil Court } \\
n=878\end{array}$ & Court fee & $\begin{array}{c}\text { Wage costs } \\
\text { duration of } \\
\text { process }\end{array}$ & $\begin{array}{l}\text { Wage costs time } \\
\text { to termination }\end{array}$ & & $\begin{array}{c}\text { Severance } \\
\text { payment }\end{array}$ & $\begin{array}{c}\text { Total dismissal } \\
\text { costs }\end{array}$ \\
\hline Mean & $€ 102$ & $€ 765$ & $€ 3,496$ & & $€ 26,619$ & $€ 30,982$ \\
\hline Median & $€ 104$ & $€ 216$ & $€ 2,213$ & & $€ 10,159$ & $€ 13,708$ \\
\hline Std. Dev. & $€ 7$ & $€ 1,791$ & $€ 4,315$ & & $€ 52,370$ & $€ 54,808$ \\
\hline Min & $€ 67$ & $€ 0$ & $€ 0$ & & $€ 0$ & $€ 97$ \\
\hline Max & $€ 118$ & $€ 17,033$ & $€ 37,730$ & & $€ 664,174$ & $€ 683,947$ \\
\hline
\end{tabular}

+ When an employee is ill for longer than two years, the employer is no longer obliged to pay the salary of the employee. For dismissals due to illness of the employee, we did multiply the gross wage of the concerned employee with the duration of the dismissal (including time to notice, period of notice for PES dismissals and time to termination for civil court dismissals) when calculating the ongoing wage costs. Herewith we assume that the loss in productivity of the concerned employee equals the wage costs of that concerned employee. 


\section{CHAPTER 4}

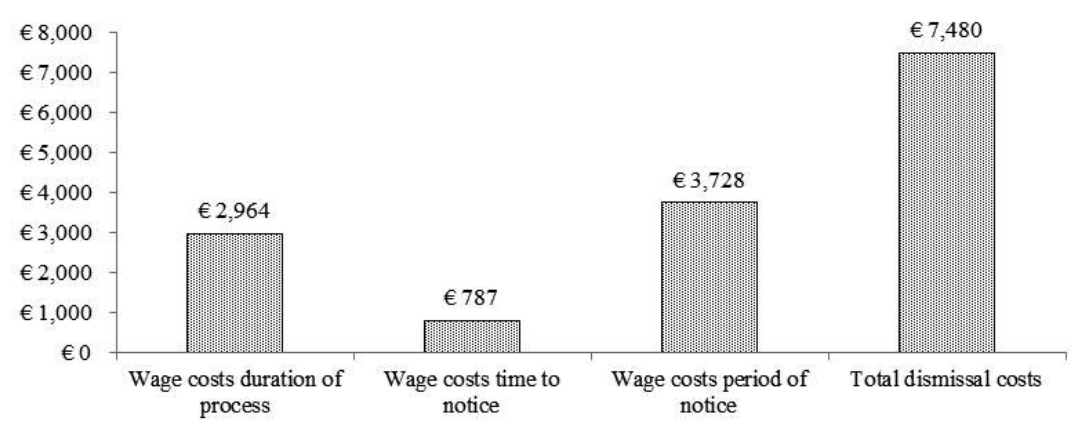

Figure 3a PES dismissal costs, per cost component ( $n=994,2006-2009)$.

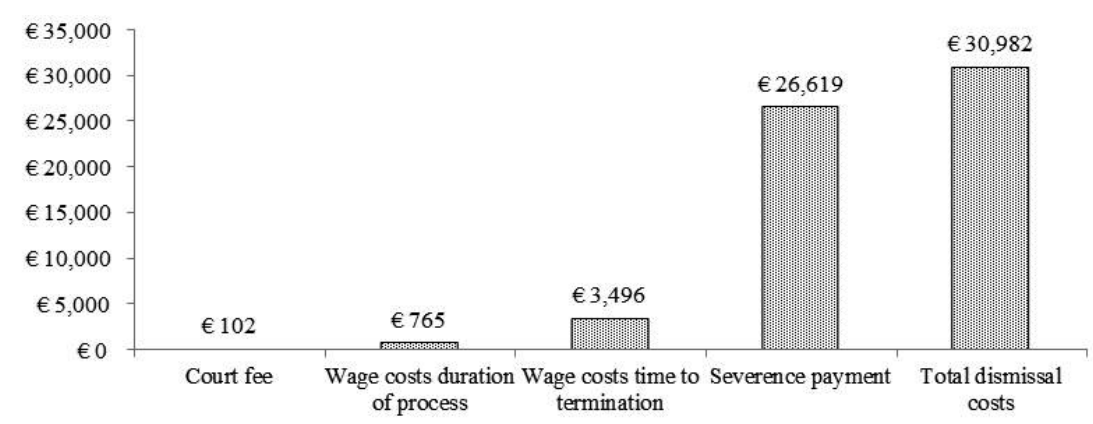

Figure 3b Civil court dismissal costs, per cost component ( $n=878,2006-2009)$.

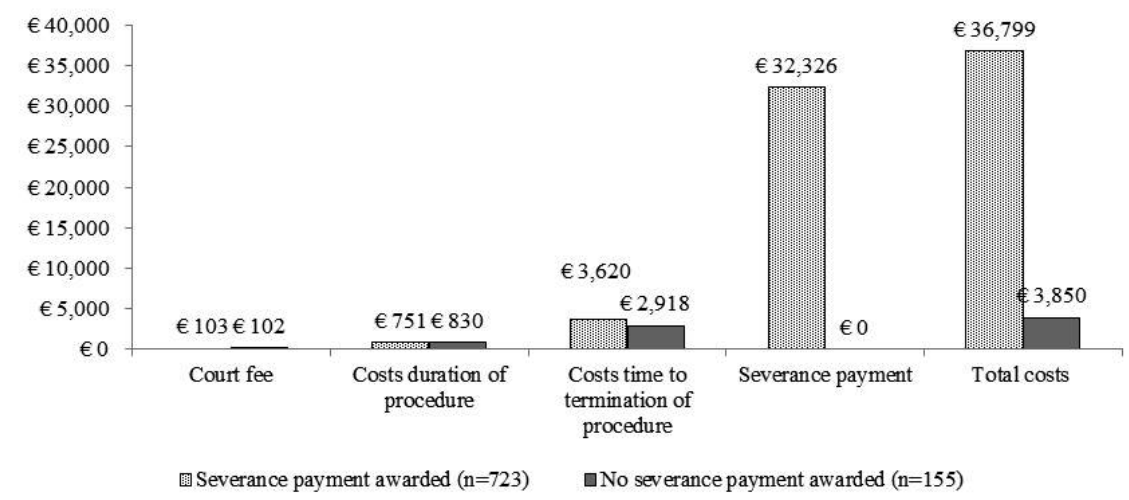

Figure 3c Civil court dismissal costs, per cost component, by severance payment ( $n=878,2006-2009)$. 


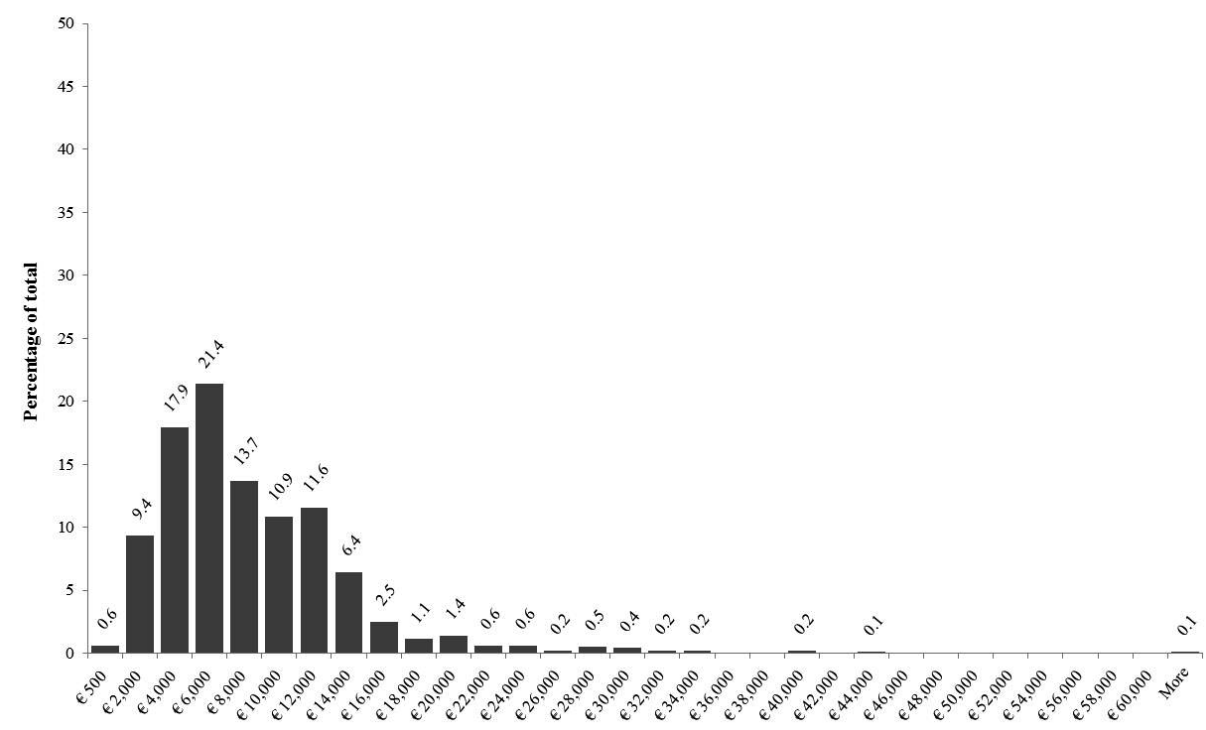

Figure 4a Distribution of costs: PES data ( $n=994,2006-2009)$.

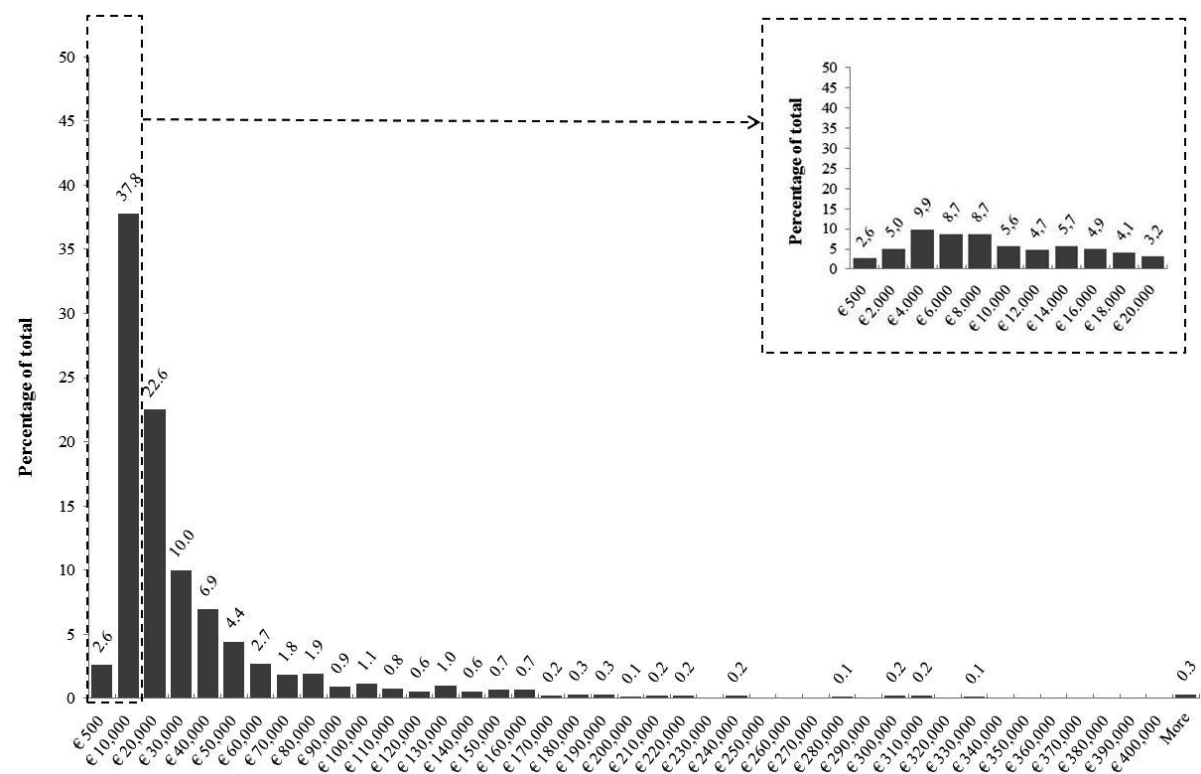

Figure 4b Distribution of costs: civil court data ( $n=878,2006-2009)$.

Ongoing wage costs that are paid during the time to the termination of the employment contract equal $€ 3,496$, which is quite a substantial amount of total costs. The severance pay cost component of $€ 26,619$ is the largest cost component that employers face. In 155 cases however, which is $\mathbf{1 7 . 5}$ percent of total, severance payments equal $€ 0$. If we distinguish 
between cases in which severance payments are awarded and those in which severance payments are not awarded differences in costs are large. Average total dismissal costs incurred by employers that are sentenced to award severance payment equal $€ 36,799$ average total dismissal costs of those employers who are not sentenced to award severance payment equal $€$ 3,850 (Figure 3c).

Figure $4 \mathrm{~b}$ gives a graphical presentation of the distribution of total civil court dismissal costs in our sample. The distribution of costs is skewed to the right. 2.6 percent of cases cost below $€ 500$ and 0.3 percent of cases cost more than $€ 400,000$. The majority of cases cost between $€ 500$ and $€ 10,000$. If we match the scale of the $x$-axis of the civil court distribution to the scale of the $x$-axis of the PES distribution for costs between $€ 500$ and $€ 20,000$, we obtain the figure in the right corner of Figure $4 \mathrm{~b}$. It shows percentages much lower than the PES distribution.

Our cost calculations are consistent with the cost calculations of Hassink et al. (1998). Translated into 2006 constant prices and euros, Hassink et al. calculated civil court costs to be between $€ 25,983$ and $€ 26,662$ and PES costs to be $€ 6,968$. ${ }^{141,142,143}$

\section{Specific dismissal costs}

In the section above we presented average dismissal costs per procedure, this section explores whether dismissal costs are different for different workers, different types of employers and different reasons of dismissal. Figure $5 \mathrm{a}$ and Figure $5 \mathrm{~b}$ present a graph with age in years on the $x$-axis and the average dismissal costs on the $y$-axis. Figure 5 a depicts the situation of the PES, Figure $5 b$ that of the civil court. Both figures show that dismissal costs are a concave function of age. Since costs are a function of earnings, this is in line with Mincer's (1958) formulation of earnings as a concave function over one's labor market experience. Moreover, with regards to dismissals via PES, for younger workers, the ongoing wage costs incurred during the duration of the PES procedure are higher than the ongoing wage costs incurred during the period of notice. An equilibrium is reached around the age of 35 in the sense that at this age both costs are equal. After 35 , the opposite is seen and the ongoing wage costs during the period of notice transcend the ongoing wage cost that are incurred during the duration of the procedure. A logical explanation is that tenure, and as such the period of notice, increases with age. The duration of the process does not. Figures $6 a$ and Figure $6 \mathrm{~b}$ show a graph with tenure in years on the $\mathrm{x}$-axis and the average dismissal costs on the $y$-axis. Similar patterns as in Figure $5 a$ and Figure $5 b$ are shown.

\footnotetext{
${ }^{141}$ Fl. 12,838 at PES versus Fl. 47,869 - Fl. 49,119 at civil court.

${ }^{142}$ The cost components used by Hassink et al. are slightly different from the costs components that we use. For the calculation of costs the PES procedure, they do not take into account the time to notice. Furthermore, for the calculation of costs of the civil court procedure Hassink et al. also include the costs of legal support. When subtracting these legal support costs from the total costs of the civil court procedure, Hassink et al.'s calculated costs are between $€ 20,037$ and $€ 20,148$ (in constant prices).

${ }^{143}$ Our results are also similar to the results of Knegt and Tros (2007), in the sense that these authors show that dismissal costs are much higher for the civil court procedure than for the PES procedure. However, the authors show a magnitude of the difference between the two procedures that is smaller. Knegt and Tros show costs of $€ 16,112$ and $€ 35,316$ for the PES procedure and for the civil court procedure, respectively. Our study however, does not take into account the costs of schooling and outplacement procedures, the study of Knegt and Tros does. Furthermore, the study of Knegt and Tros is based upon self-reported measures of employers and employees, our study is based on actual dismissal cases filed at the civil court and the PES.
} 
Figure 7 shows dismissal costs for economical and non-economical dismissals. At the PES, differences in costs are negligible. Total dismissal costs for non-economical dismissal equal $€ 7,339$. Total dismissal costs for economical dismissals are $€ 7,532$. At the civil court, larger differences are found. Economical dismissals are almost twice the costs of non-economical dismissals. The former are $€ 42,994$, the latter are $€ 26,918$. The higher severance payments awarded when economic motives are at stake explain the largest difference in costs.

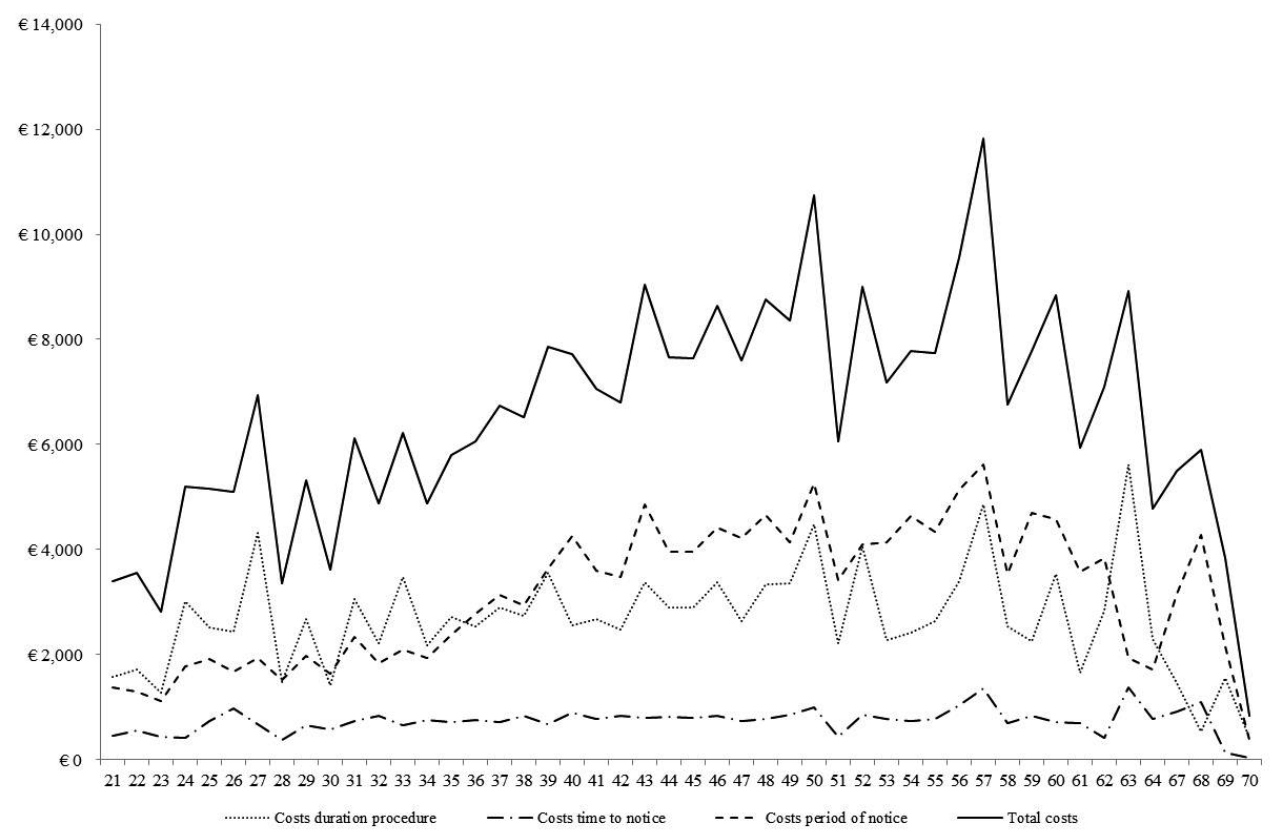

Figure 5a PES: Age and dismissal costs ( $n=994,2006-2009)$. 


\section{CHAPTER 4}

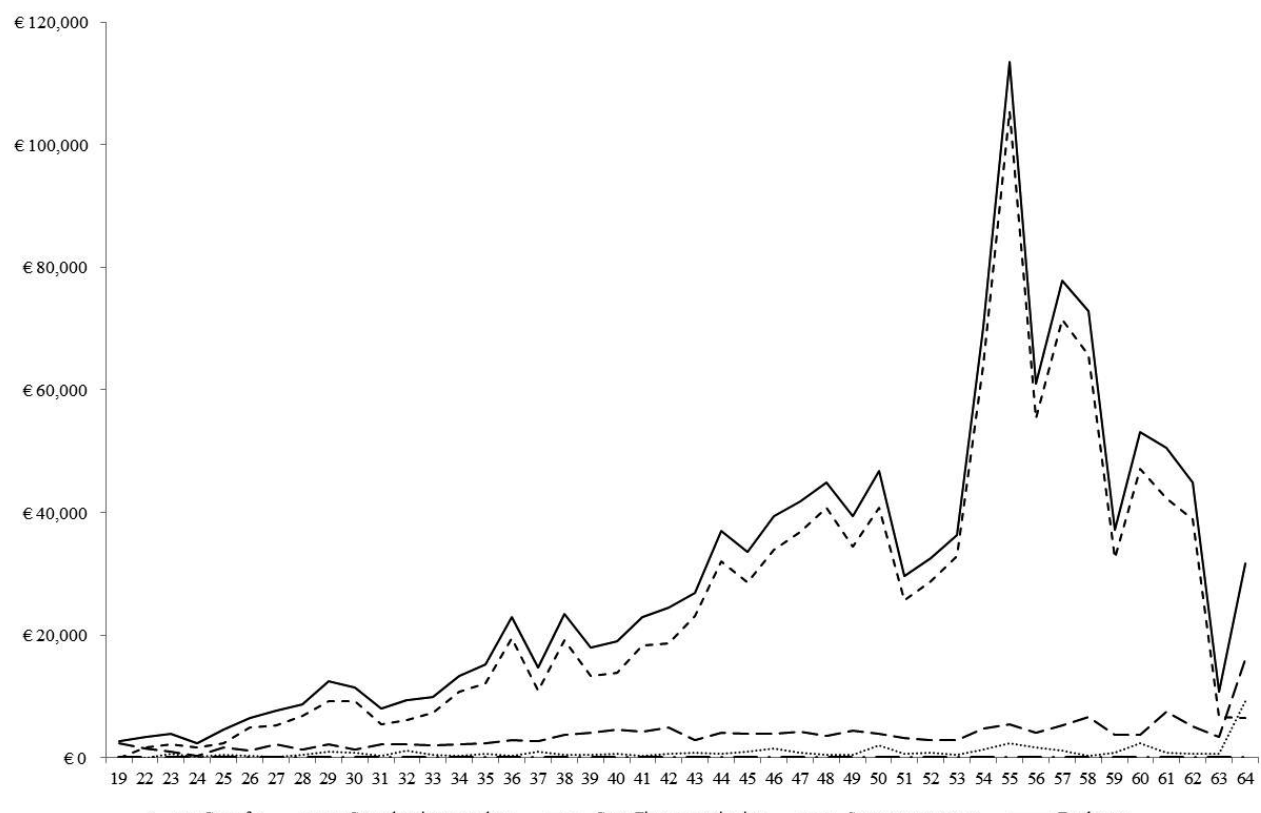

Figure 5b Civil court: Age and dismissal costs ( $n=878,2006-2009)$.

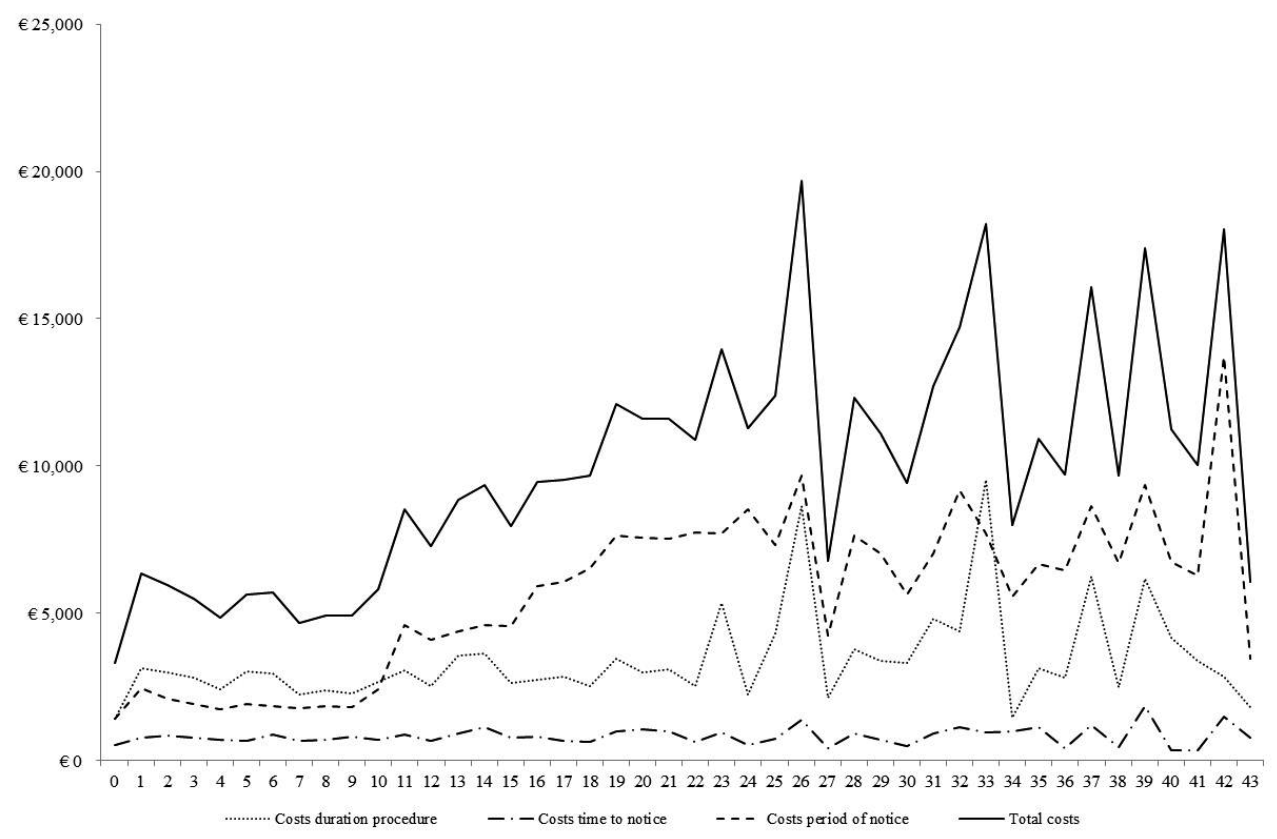

Figure 6a PES: Tenure and dismissal costs ( $n=994,2006-2009)$. 


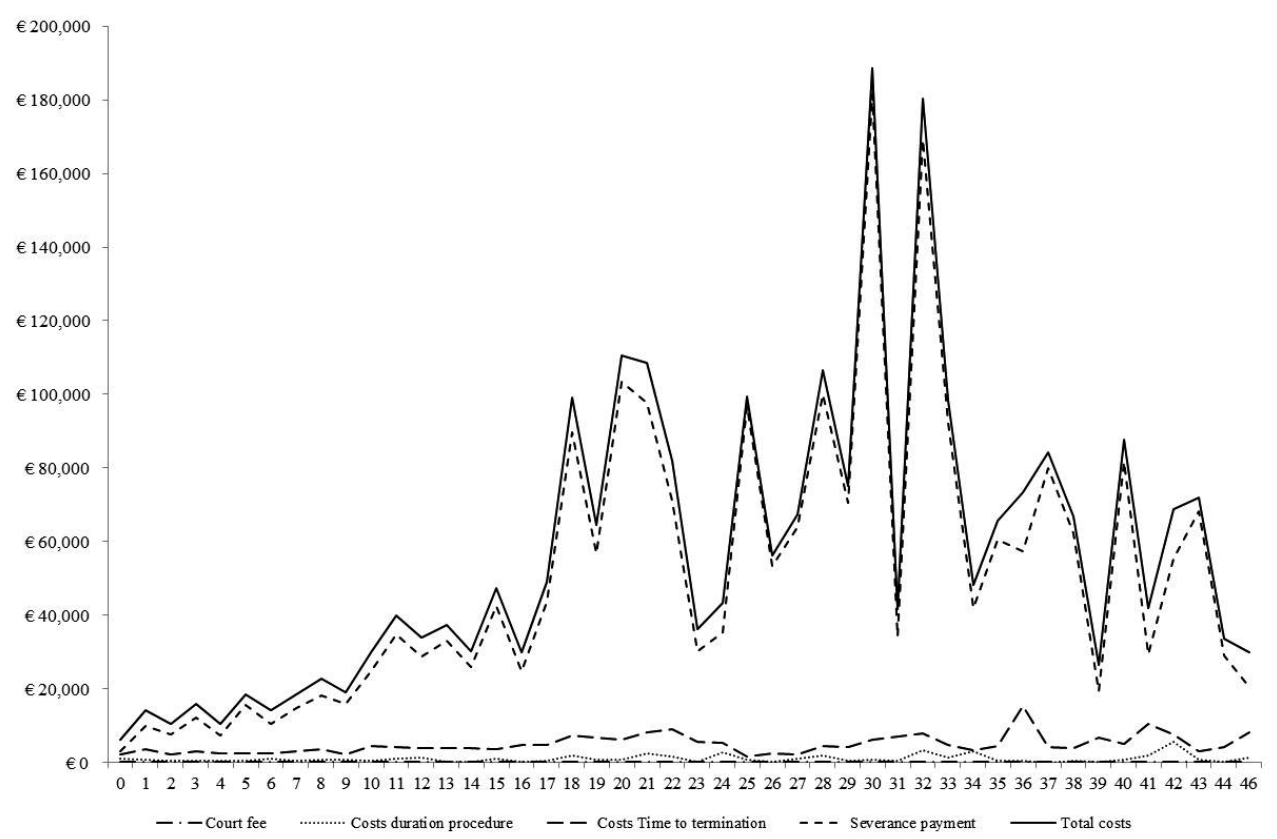

Figure 6b Civil court: Tenure and dismissal costs ( $n=878,2006-2009)$.

Figure 8 shows dismissal costs for collective and non-collective dismissals at the PES. Collective dismissals are more expensive than non-collective dismissals. Costs are $€ 9,392$ versus $€ 6,738$, respectively. Figure 8 also shows the difference in costs between pro-forma procedures and non pro-forma procedures at the civil court. Differences in costs between these two types of procedures are minimal. Pro-forma procedures cost $€ 30,910$, and non pro-forma procedures cost $€ 31,419$. The way in which these costs are build up, however, are different. For non proforma cases, the ongoing wage costs made during the duration of the civil court procedure equal $€ 2,935$. For pro-forma cases, these ongoing wage costs equal $€ 405$. Yet, for non-proforma cases the ongoing wage costs made during the time to termination are much lower than for pro-forma cases. The former equal $€ 1,998$, the latter equal $€ 3,745$, Costs of severance payment are similar.

Figure 9 presents the differences in dismissal costs for employers in different industries. At the PES, costs incurred are the highest for employers that operate in the industry sector. These employers incur costs of $€ 10,314$. Employers that operate in the health sector incur the lowest costs, namely $€ 5,454$. With respect to the civil court procedure, the most expensive dismissal procedures are seen in the industry sector, the least expensive dismissal procedures are seen in the wholesale sector. A dismissal procedure in the industry sector costs $€ 46,421$, a dismissal procedure in the wholesale sector costs $€ 18,340$.

Figure 10 distinguishes in costs between small, medium and large companies. With respect to the PES procedure, employers employing less than 10 employees incur a cost of $€ 5,283$. Employers employing between 10 and 100 employees incur a cost of $€ 7,578$, and employers employing more than employees incur a cost of $€ 9,088$. These results show that dismissal costs increase with the size of the employer. A similar pattern is found for the civil court procedure. 


\section{CHAPTER 4}

Employers employing less than 10 employees, employers employing between 10 and 100 employees and employers employing between 10 and 100 employees incur costs of $€ 9,519$, $€ 20,851$ and $€ 40,442$, respectively.

PES (7a)

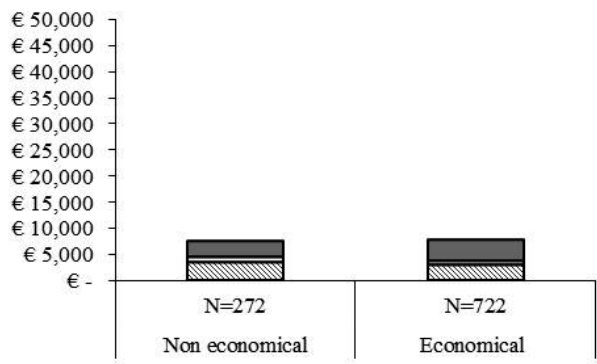

Costs duration of procedure

$\square$ Costs time to notice

$\square$ Costs period of notice

Input for Figure 7a

\begin{tabular}{lcc}
\hline & $\begin{array}{c}\text { Non } \\
\text { economical }\end{array}$ & Economical \\
\hline Costs duration of & $\mathrm{n}=272$ & $\mathrm{n}=722$ \\
procedure & $€ 3,437$ & $€ 2,786$ \\
Costs time to notice & $€ 866$ & $€ 758$ \\
Costs period of & & \\
notice & $€ 3,037$ & $€ 3,988$ \\
Total costs & $€ 7,339$ & $€ 7,532$
\end{tabular}

Civil court (7b)

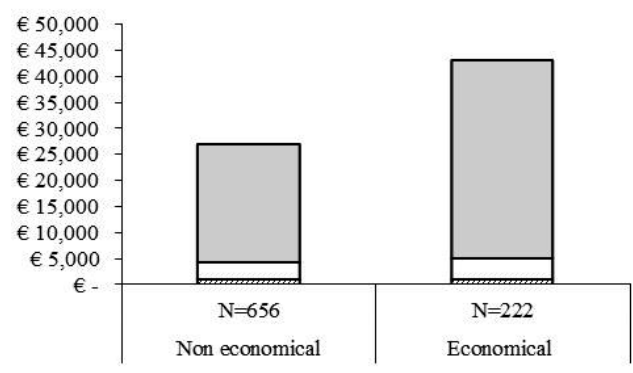

$\square$ Severance payment

$\square$ Costs time to termination of procedure

DCosts duration of procedure

$\square$ Court fee

Input for Figure $7 \mathrm{~b}$

\begin{tabular}{lcc}
\hline & $\begin{array}{c}\text { Non } \\
\text { economical }\end{array}$ & Economical \\
\hline $\begin{array}{l}\text { Court fee } \\
\text { Costs duration of }\end{array}$ & $€ 656$ & $\mathrm{n}=222$ \\
procedure & $€ 702$ & $€ 104$ \\
Costs time to & & $€ 839$ \\
termination & $€ 3,357$ & $€ 3,905$ \\
$\begin{array}{l}\text { Severance payment } \\
\text { Total costs }\end{array}$ & $€ 22,718$ & $€ 38,146$ \\
& $€ 26,918$ & $€ 42,994$
\end{tabular}

Figure 7 The costs of economical versus non-economical dismissals (in 2006 constant prices) (2006-2009).

Figure 11 presents differences in dismissal costs with respect to gender. Procedures in which females are involved are less costly than procedures in which men are involved. At the PES, procedures involving women cost $€ 4,847$, procedures involving men cost $€ 9,312$. At the civil court, procedures involving women cost $€ 19,832$, and procedures involving men cost $€ 38,122$.

Last, Figure 12 distinguishes in costs between different types of legal forms of the employer. At the PES, costs incurred are highest for employers holding a limited liability private firm (BV) and lowest for employers that are sole traders (VOF). These costs are €8,217 and $€ 4,147$, respectively. At the civil court, a similar pattern is found. Costs are highest for limited liability private (BV) firms and lowest for sole traders (VOF). These costs are €33,511 and $€ 10,770$, respectively. 
PES (8a)

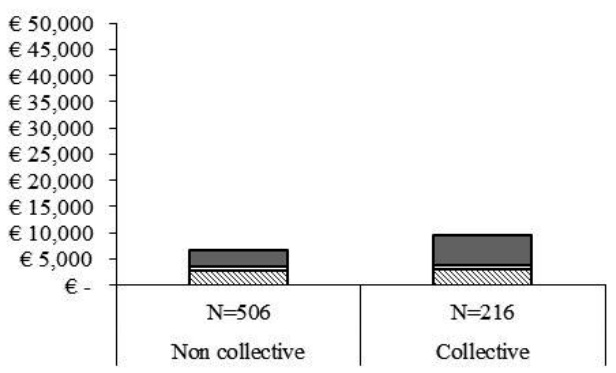

QCosts duration of procedure

$\square$ Costs time to notice

$\square$ Costs period of notice

Input for Figure 8a

\begin{tabular}{lcc}
\hline & Non collective & Collective \\
\hline Costs duration of & $n=506$ & $n=216$ \\
procedure & $€ 2,690$ & $€ 3,012$ \\
Costs time to notice & $€ 752,53$ & $€ 769$ \\
Costs period of & & \\
notice & $€ 3,296$ & $€ 5,611$ \\
Total costs & $€ 6,738$ & $€ 9,392$
\end{tabular}

Civil court (8b)

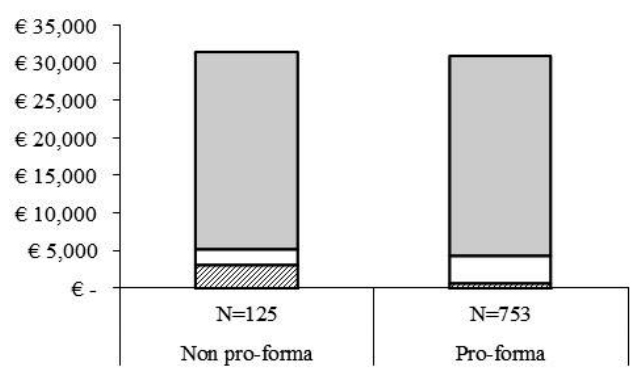

$\square$ Severance payment

$\square$ Costs time to termination of procedure

$\square$ Costs duration of procedure

$\square$ Court fee

Input for Figure 8b

\begin{tabular}{lcc}
\hline & Non pro-forma & Pro-forma \\
\hline & $\mathrm{n}=125$ & $\mathrm{n}=753$ \\
Court fee & $€ 102$ & $€ 103$ \\
$\begin{array}{l}\text { Costs duration of } \\
\text { procedure }\end{array}$ & $€ 2,935$ & $€ 405$ \\
Costs time to & & \\
termination & $€ 1,998$ & $€ 3,745$ \\
Severance payment & $€ 26,384$ & $€ 26,658$ \\
Total costs & $€ 31,419$ & $€ 30,910$ \\
\hline
\end{tabular}

Figure 8 Costs of (non) collective dismissal and (non) pro-forma cases (in 2006 constant prices) (2006-2009).

\subsection{Conclusion}

An employer in the Netherlands has two options to terminate a permanent employment contract. He may turn the PES for a dismissal permission, or he may ask the civil court to dissolve the employment contract ${ }^{144}$. Both procedures induce certain costs. This dissertation is the first to use a unique sample of 998 individual dismissal cases filed at the PES and 878 individual dismissal cases filed at the civil court to calculate the exact costs of both the PES procedure and the civil court procedure. Our results show that the civil court procedure is approximately four times more expensive than the PES procedure. An average dismissal procedure at civil court costs $€ 30,982$. An average PES dismissal procedure costs $€ 7,479$. Median differences however are much smaller. Furthermore, an examination of real life cases shows that the civil court is not always the most expensive route to follow. In 17 percent of all cases (155 cases), severance payments are equal to zero and average dismissal costs are below $€ 4,000$.

\footnotetext{
${ }^{144}$ As mentioned earlier, other options to terminate an employment contract are at will during the trial period, termination by mutual consent, termination by operation of law ${ }^{144}$ and by summary dismissal. These cases are not covered by our data.
} 
We fill a gap in literature by observing actual dismissal cases. The studies of Hassink et al. (1998) and Knegt and Tros (2007) that also calculate the dismissal costs of both the PES procedure and the civil court procedure are based on surveys, and not on actual dismissal data. The observation of almost 2000 actual dismissal files enables us to be more accurate because we do not have to rely on self-reported values of employers and employees. Furthermore, we make a distinction in costs with respect to different characteristics related to the employee and the employer involved. This distinction allows for a better understanding of how firing decisions are made. For example, costs of economic dismissals via the civil court are almost six times larger than costs of economic dismissals via the PES ( $€ 42,994$ vs. $€ 7,532)$ This cost difference puts additional strength to our argument that employers select a route strategically. Based on principles of economic efficiency one would predict that employers select the route with the lowest expected costs. An unobservable factor other than costs, however, results in the selection of the civil court route. The likelihood of success is one of those factors.

This distinction also allows us to predict the effect of the abolishment of one of both routes. For example, smaller firms are more likely to follow the PES route of dismissal. When abolishing the PES route, these employers will be forced to select the more expensive civil court route. Dismissals due to a disturbed relationship are mostly filed the civil court and rarely appear in front of PES. This is an indication that the civil court is a superior institute in judging whether a reasonable ground exists in disputes concerning the functioning of an employee. Similarly, one may argue that the PES is more specialized in prolonged illness dismissal requests. Abolishing the one or the other route will result in the destruction of a specialism of the specific route that is abolished.

The calculation of average dismissal costs of the current system as we presented in this chapter moreover allows for the comparison of costs of the current system and of any proposed modification in general. This idea is presented in Chapter 7 of this dissertation in which we show that the latest proposal to modify the Dutch EPL of June 2012 is not likely to result in a decrease in average firing costs. Employers that originally selected the PES route will incur costs that are higher than in the system as it exists today, employers that originally selected the civil court route are confronted with a decrease in costs.

We conclude this chapter by expressing that a choice per definition implies greater flexibility. Taking these thoughts one step further, we propose to formulate a model that explains the strategic choice of employers. The expected costs of both procedures are used as input for this model. This model can be used for sensitivity analysis to assess the impact of a modification of EPL on the working of the labor market. ${ }^{145}$

\footnotetext{
${ }^{145}$ In this chapter we showed that costs of dismissals via the civil court are on average higher than the costs of dismissal via the PES route. Herewith we do not express our preference for the PES route. It is an objective observation. Throughout this dissertation we plead for the maintenance of the dual preventative system.
} 
FIRING COSTS
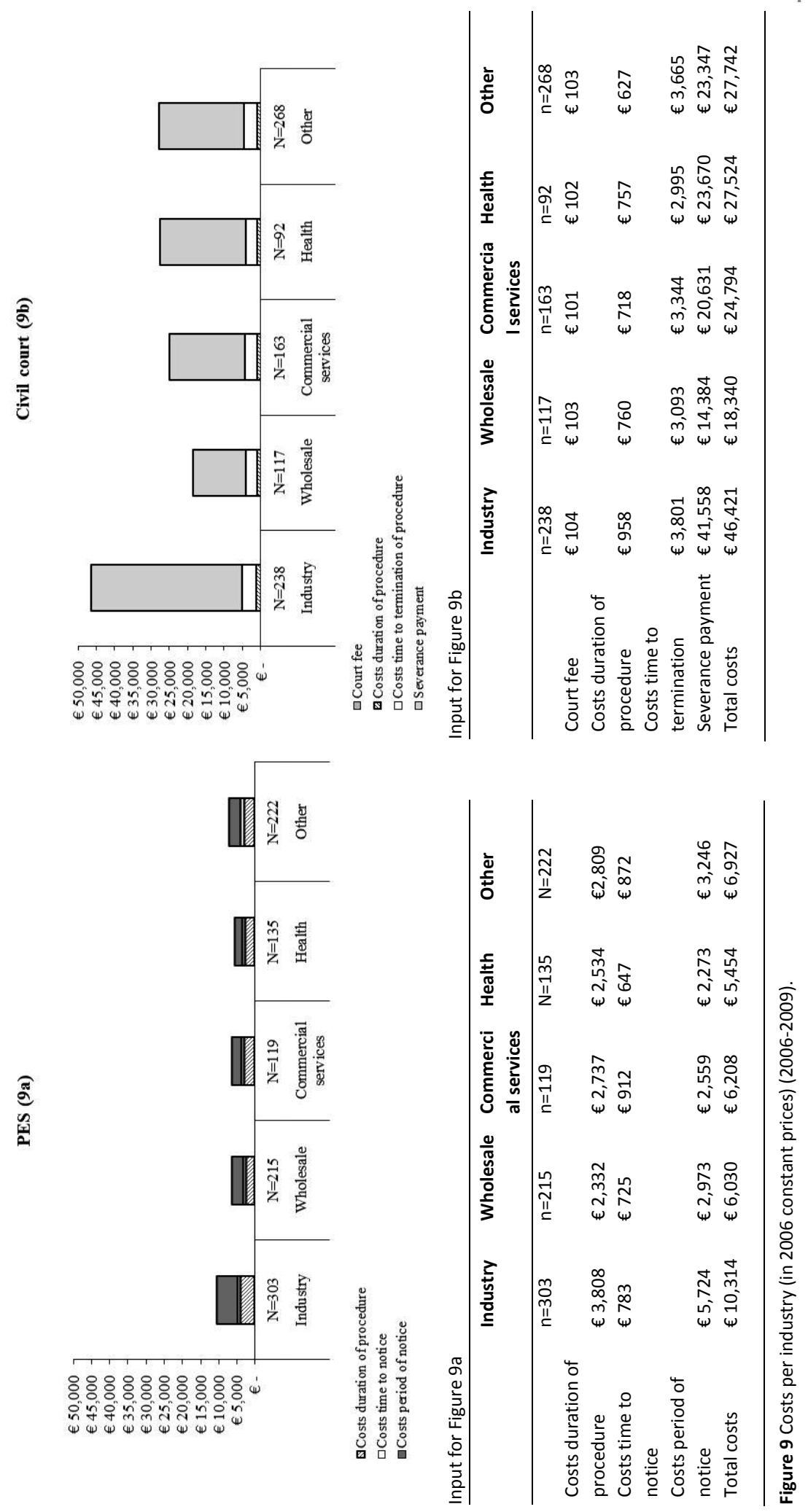
PES (10a)

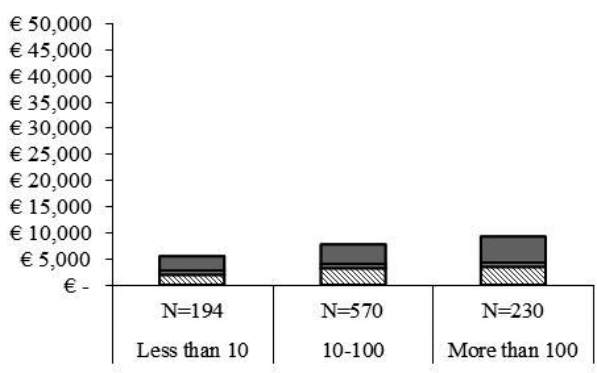

QCosts duration of procedure $\square$ Costs time to notice

$\square$ Costs period of notice

Input for Figure 10a

\begin{tabular}{lccc}
\hline & $<\mathbf{1 0}$ & $\mathbf{1 0 - 1 0 0}$ & $>\mathbf{1 0 0}$ \\
\hline & $\mathrm{n}=194$ & $\mathrm{n}=570$ & $\mathrm{n}=230$ \\
Costs duration of & & & \\
procedure & $€ 1,929$ & $€ 3,181$ & 3,300 \\
Costs time to & $€ 705$ & $€ 780$ & $€ 874$ \\
notice & & & \\
Costs period of & & & \\
notice & $€ 2,648$ & $€ 3,617$ & $€ 4,914$ \\
Total costs & $€ 5,283$ & $€ 7,578$ & $€ 9,088$ \\
& & &
\end{tabular}

Civil court (10b)

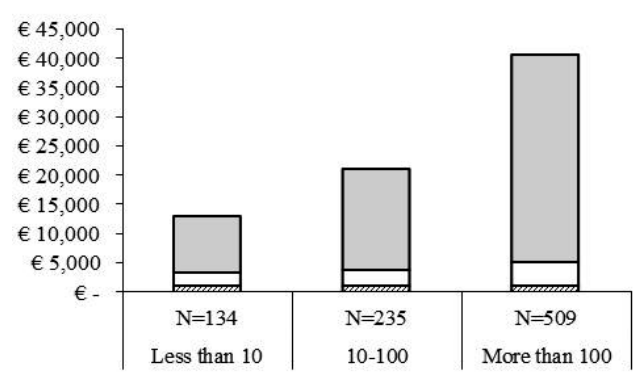

$\square$ Severance payment

$\square$ Costs time to termination of procedure

DCosts duration of procedure

$\square$ Court fee

Input for Figure 10b

\begin{tabular}{|c|c|c|c|}
\hline & $<10$ & $10-100$ & $>100$ \\
\hline & $n=134$ & $n=235$ & $n=509$ \\
\hline Court fee & $€ 98$ & $€ 103$ & $€ 103$ \\
\hline $\begin{array}{l}\text { Costs duration of } \\
\text { procedure }\end{array}$ & $€ 780$ & $€ 839$ & $€ 727$ \\
\hline $\begin{array}{l}\text { Costs time to } \\
\text { termination }\end{array}$ & $€ 2,420$ & $€ 2,672$ & $€ 4,160$ \\
\hline Severance payment & $€ 9,519$ & $€ 17,238$ & $€ 35,452$ \\
\hline Total costs & $€ 12,816$ & $€ 20,851$ & $€ 40,442$ \\
\hline
\end{tabular}

Figure 10 Costs according to firm size (in 2006 constant prices) (2006-2009). 
PES (11a)

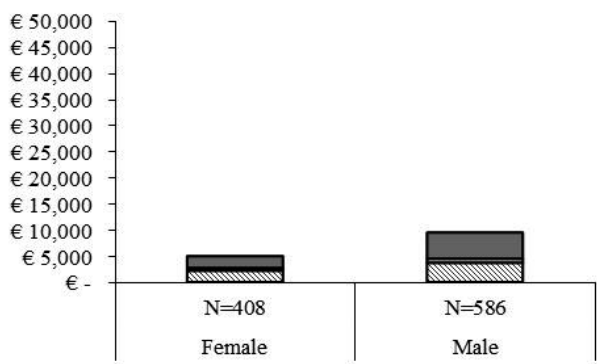

Costs duration of procedure

$\square$ Costs time to notice

$\square$ Costs period of notice

Input for Figure 11a

\begin{tabular}{lcc}
\hline & Female & Male \\
\hline Costs duration of & $n=408$ & $n=586$ \\
procedure & $€ 2,133$ & $€ 3,543$ \\
Costs time to notice & $€ 561$ & $€ 945$ \\
Costs period of & & \\
notice & $€ 2,153$ & $€ 4,825$ \\
Total costs & $€ 4,847$ & $€ 9,312$ \\
& &
\end{tabular}

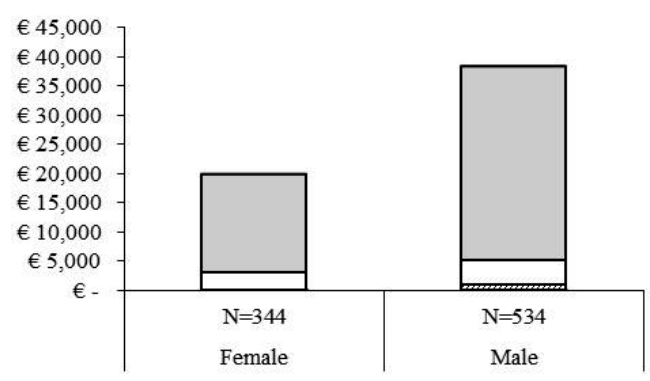

$\square$ Severance payment

$\square$ Costs time to termination of procedure

v Costs duration of procedure

$\square$ Court fee

Input for Figure $11 b$

\begin{tabular}{lcc}
\hline & Female & Male \\
\hline & $\mathrm{n}=344$ & $\mathrm{n}=534$ \\
Court fee & $€ 102$ & $€ 103$ \\
$\begin{array}{l}\text { Costs duration of } \\
\text { procedure }\end{array}$ & $€ 454$ & $€ 965$ \\
Costs time to & & \\
termination & $€ 2,554$ & $€ 4,102$ \\
Severance payment & $€ 16,721$ & $€ 32,995$ \\
Total costs & $€ 19,832$ & $€ 38,166$ \\
\hline
\end{tabular}

Figure 11 Costs according to gender (in 2006 constant prices) (2006-2009). 

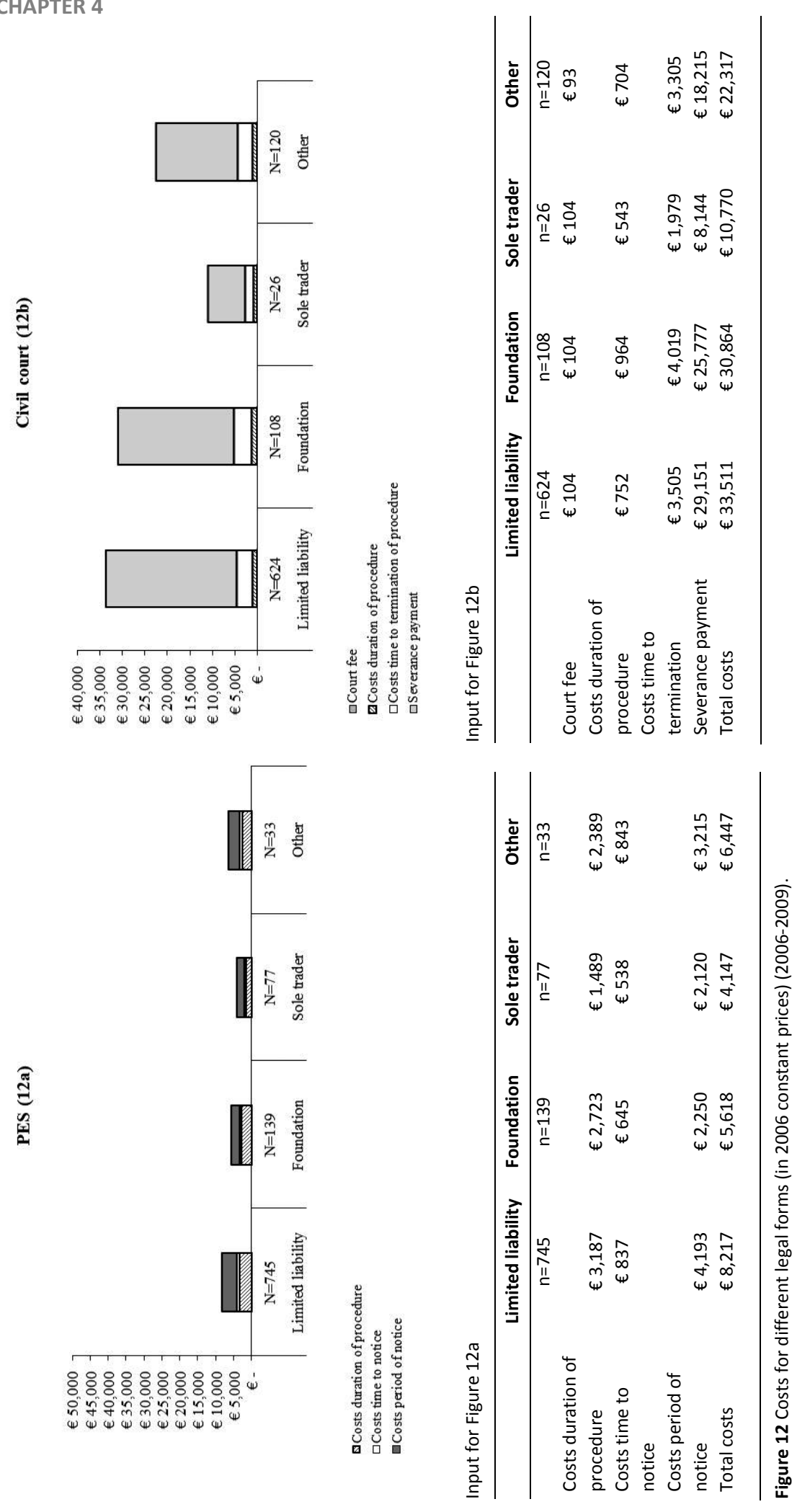
CHAPTER 5:

JOB SECURITY AND SEVERANCE PAY LENIENCE IN RECESSION 


\subsection{Introduction ${ }^{146}$}

According to existing labor market theories and common belief countries with strong employment protection will have high unemployment rates and low employment participation levels, especially in Europe (e.g. Emerson (1988), Bertola (1990), and Blanchard and Portugal (2001)). This chapter, Section 2, presents a comparison of the EU15 countries. It shows that the Dutch labor market is marked with one of the strongest employment protection laws for workers with job tenure, but in the meantime the country's economy is among the top 3 performers in Europe with respect to unemployment levels, labor market participation and worker productivity. We argue that this remarkable phenomenon is based on a long-lasting characteristic of duality in the Dutch labor market, a feature that has been overlooked by most of the existing scholarly research on labor market institutions, job protection and social insurance. ${ }^{147}$ Firms in the Netherlands have a unique option to choose from two different ways to dissolve tenured worker contracts. One possibility is to ask the public employment service $(P E S)^{148}$ for a dismissal permission. The other possibility is to request the court to dissolve the contract. The check on the reasonableness of dismissal is a preventative check. The most important difference between the PES and the civil court is that the PES relieves the firm from the obligation of severance payment.

In Section 3 we shortly present the Dutch system in more detail. We shows that larger firms tend go to court more. Furthermore, employees involved in the civil court procedure earn slightly higher wages. On average the duration of the court procedure is shorter (three weeks), but the expected length of the procedure is more unpredictable. As shown in the previous chapter of this dissertation the expected costs are higher and more uncertain. This is predominantly caused by the fact that severance payments are determined by court ruling and when a dismissal is approved by the PES the firm is relieved from the obligation of severance payment. Severance pay lenience for firms in distress is a unique feature of the Dutch labor market that results from the duality in the Dutch system.

Section 4 presents a simple theoretical equilibrium model to study the system's effects. The model predicts that as long as the wage elasticity of labor demand does not exceed the inverse of the replacement ratio a system of severance payment exemption is less costly than the alternative of additional unemployment benefits. The likelihood that this condition holds increases when a firm is hit by a negative shock. We conclude this chapter with an outlook for future research.

\footnotetext{
${ }^{146}$ I would like to thank Prof. Dr. Pfann for the development of this thesis in general, and for the development of this chapter more specifically.

${ }^{147}$ Belot, Boone and Van Ours. (2007), and Freeman (2008a) and Freeman (2008b).

${ }^{148} \mathrm{PES}$ is used as an acronym for public employment service.
} 


\subsection{Some characteristics of European labor markets}

We start our analysis with a comparison of labor market statistics of the EU15 countries. ${ }^{149}$ In Chapter 2 of this dissertation we have presented the OECD index of the strictness in protection against individual dismissal of workers with permanent employment contracts. Of all EU15 countries, Portugal, Germany, and the Netherlands form the top three of countries with the strictest protection of permanent jobs.

According to existing labor market theory, countries with strict employment protection laws will have high levels of temporary employment, high unemployment rates, low employment participation levels, and low worker productivity. Figure 1 and Figure 2 show, respectively, temporary employment and unemployment rates for the EU15 countries. The rate of temporary workers in the Netherlands is indeed one of the highest in Europe, but the unemployment rate is among the lowest. Labor market participation in the Netherlands is the second highest in Europe (Figure 3), and labor productivity per hour worked is far above the EU15 average (Figure 4). The long-term growth in labor market participation is higher in the Netherlands than in Europe (Figure 5), and the rate of unemployment is structurally among the lowest in Europe during the past decades (Figure 6). On the basis of these comparisons it does not seem to be unreasonable to state that the Dutch labor market is an example that challenges modern theories of unemployment and worker protection.

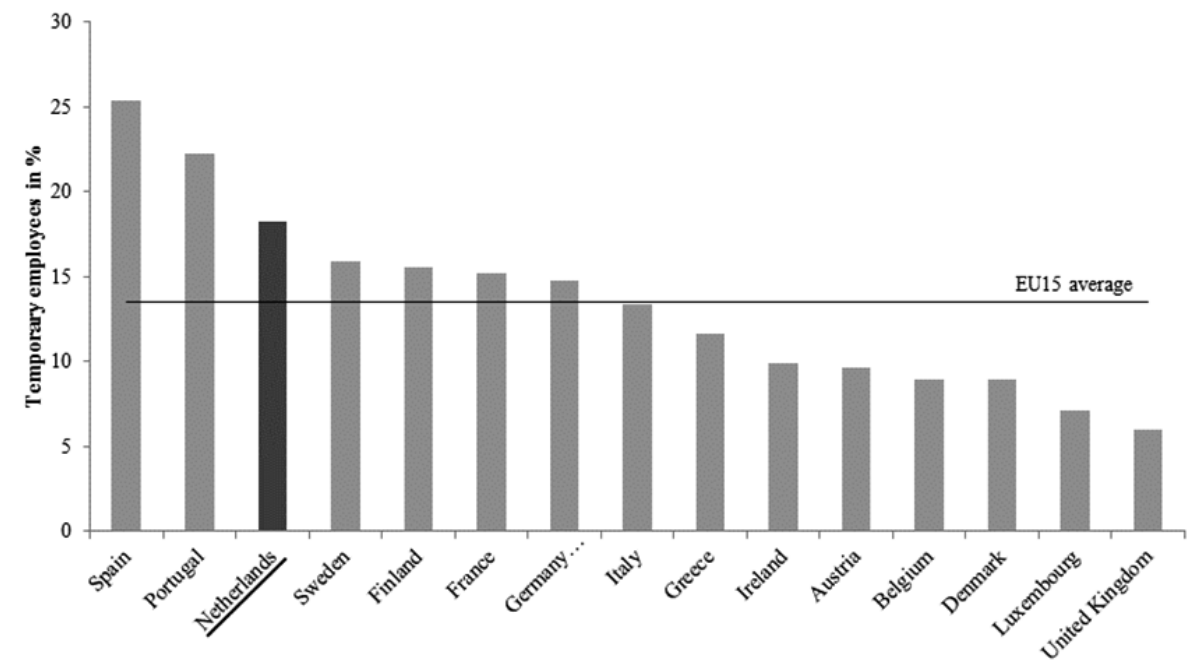

Figure 1 Temporary employment + rates in EU15 countries (Eurostat, 2011).

tTemporary employment is measured as temporary employees as percentage of the total number of employees. Data extracted on $06 \mathrm{Jul}$ 2012, Eurostat.

\footnotetext{
${ }^{149}$ The EU15 refers to the number of member countries of the European Union prior to May $1^{\text {st }}, 2004$. The countries are Austria, Belgium, Denmark, Finland, France, Germany, Greece, Ireland, Italy, Luxembourg, Netherlands, Portugal, Spain, Sweden and the United Kingdom.
} 


\section{CHAPTER 5}

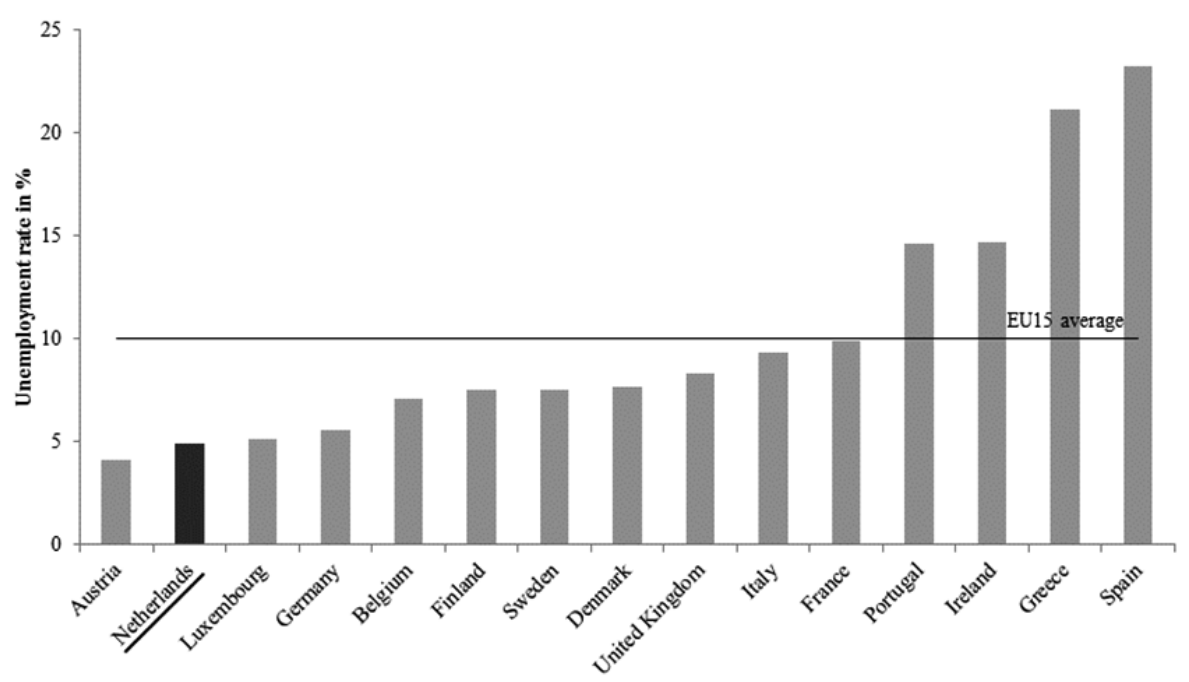

Figure 2 Unemployment ratest in EU15 countries (Eurostat, 2011).

t The unemployment rate is measured as unemployed persons as a percentage of the labour force based on International Labour Office (ILO) definition. Data extracted on $06 \mathrm{Jul} 2012$, Eurostat.

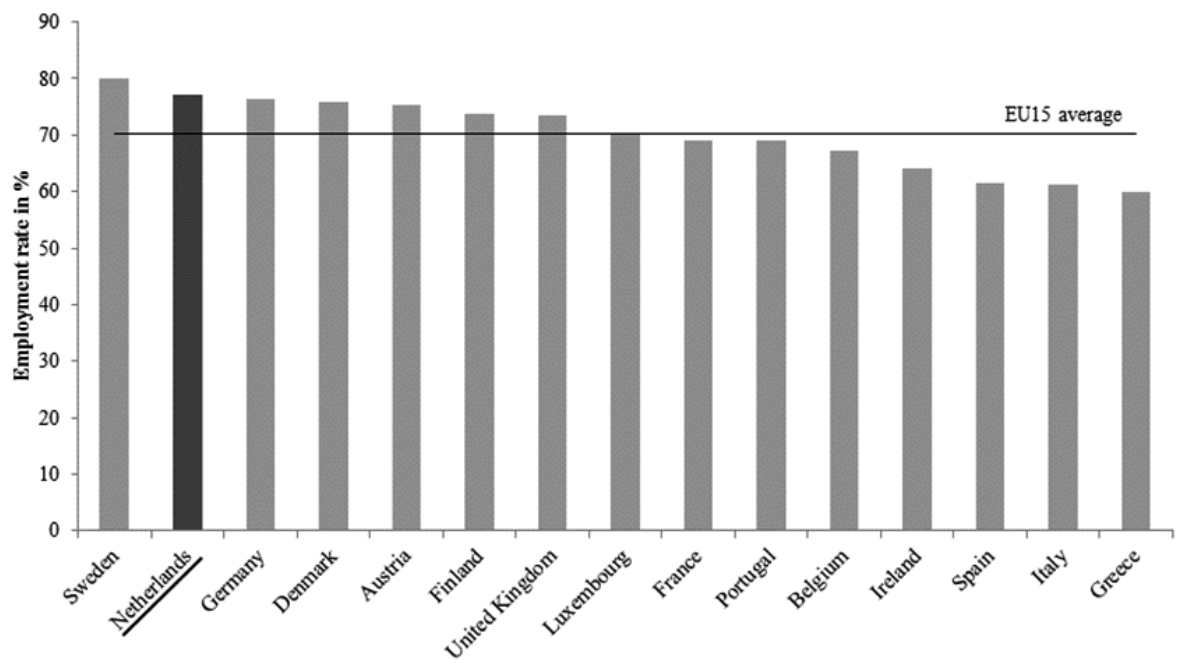

Figure 3 Labor market participation ratest in EU15 countries (Eurostat, 2011).

the labor market participation rate is calculated by dividing the number of persons aged 20 to 64 in employment by the total population of the same age group. Data extracted on $06 \mathrm{Jul} 2012$, Eurostat. 


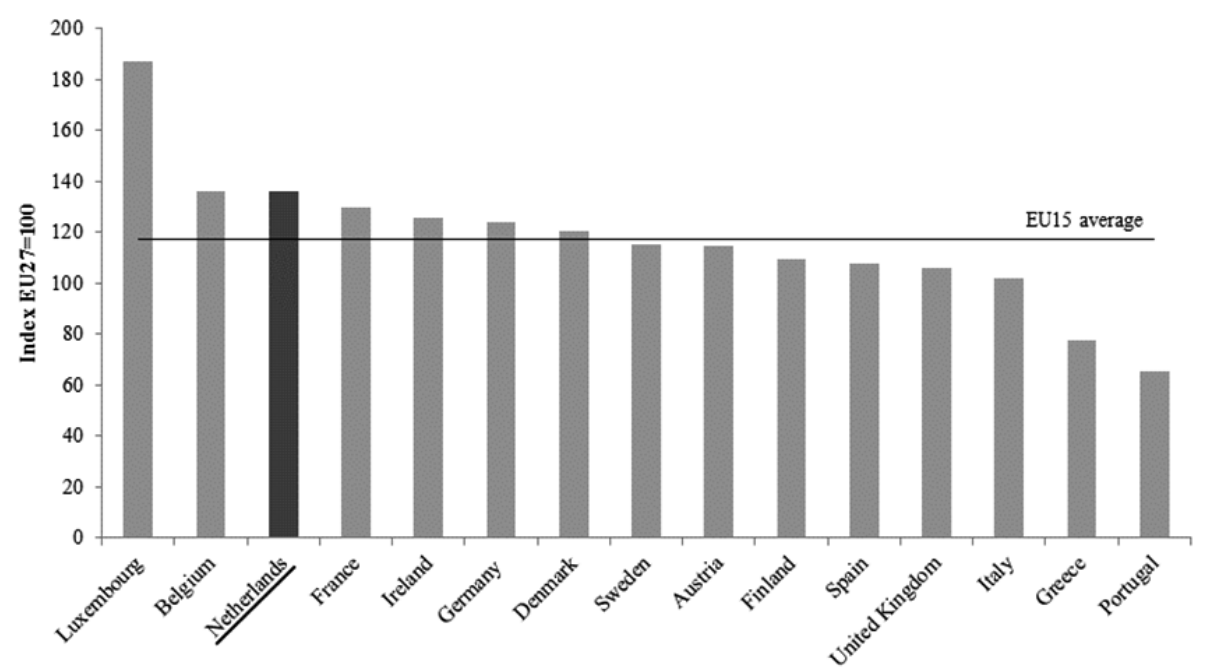

Figure 4 Labor productivity per hour worked + in EU15 countries (Eurostat, 2010*)

+ Labor productivity per hour worked is measure as GDP per hour worked. Data extracted on 06 Jul 2012, Eurostat. * Latest complete version available.

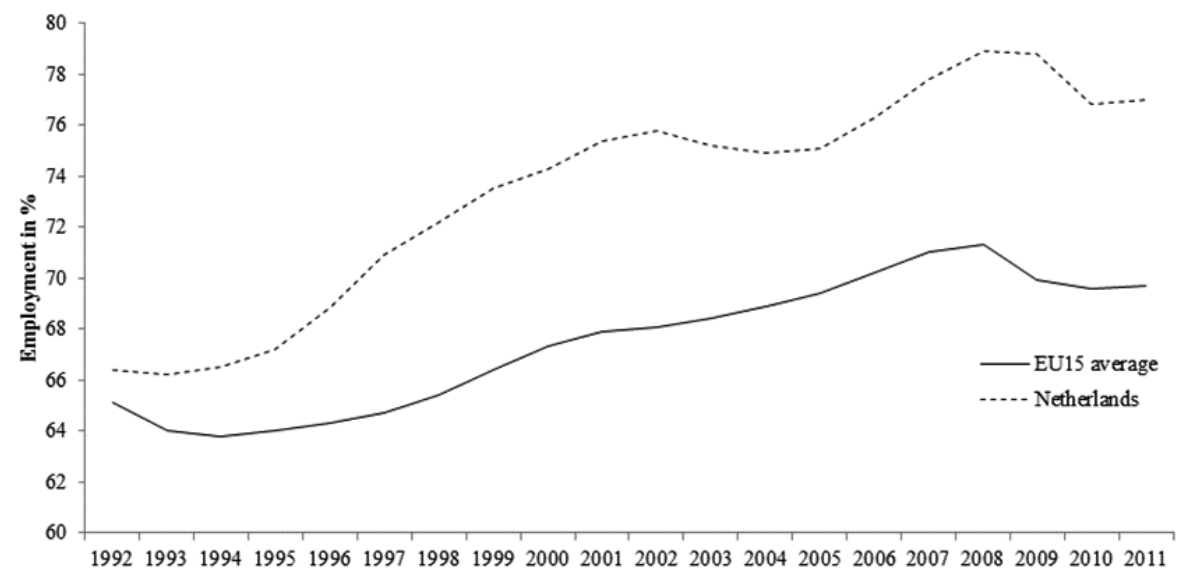

Figure 5 Labor market participation † rates though time (1992-2011), Eurostat (2011).

the labor market participation rate is calculated by dividing the number of persons aged 20 to 64 in employment by the total population of the same age group. Data extracted on $06 \mathrm{Jul} 2012$, Eurostat. 
CHAPTER 5
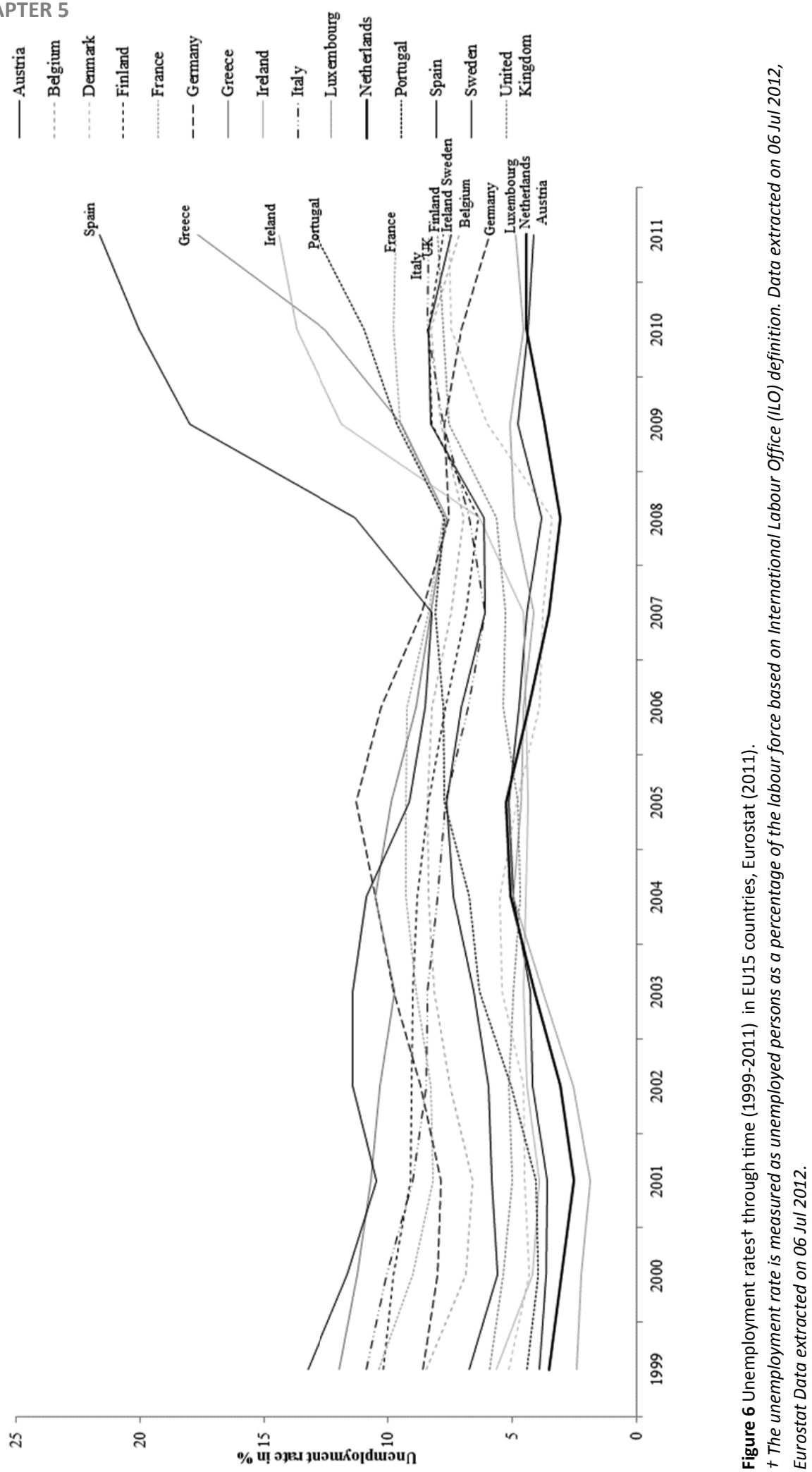


\subsection{Duality in the Dutch labor market}

What is special about the Dutch labor market in comparison to other labor markets is that it is characterized by a system of duality. This duality implies that an employer has two choices to terminate employment contracts of tenured workers. ${ }^{150}$ The first possibility is to ask the PES for a dismissal permission. The second option is to request the universal civil court to dissolve the contract. Both institutes apply a preventative check during which the reasonability of the dismissal is checked before a worker can be dismissed. The most important difference between the civil court and the PES is that when permission for dismissal is granted by the PES a firm is relieved from the obligation of severance payment. ${ }^{151}$ It can be regarded as a form of public solidarity. We interpret this as a pure cost reduction for the firm in need paid for by the government in times of economic distress. ${ }^{152}$

Figure 7 presents how the number of requests that have been filed at the PES and at the civil courts in the period 1997-2011 vary with the unemployment rate. It shows that the two routes of dismissal are chosen by employers in almost equal proportions independent of the state of the business cycle. Figure 7 furthermore shows that not only in recessions firms are granted permission from the PES to dismiss workers but during expansions also. This outcome is consistent with the fact that job destruction and job creation occur simultaneously over the business cycle (Davis and Haltiwanger (1992)). The incidence of negative demand shocks and therefore of permissions by the PES is only smaller during economic upturns. Each volume of requests is noticeably a leading indicator for the unemployment rate.

We continue this section with comparing the PES route to the civil court route with respect to differences in employees and employers involved, but also with respect to case-specific characteristics. Table 1 shows the numbers and percentages of lay-offs divided by the employment sector, firm size and gender. It furthermore shows the likelihood that the request is granted. That is, that the PES grants dismissal permission and that the civil court dissolves the contract. Pearson $\chi^{2}$ statistics and corresponding $p$-values are added to show whether differences in sample proportions are significant. An often heard argument of why employers choose the civil court route is that the likelihood of success is larger. Indeed, in less than $1 \%$ of all cases the contract is not dissolved. Win rated at PES, however, are also high. The distribution of dismissals over the various sectors does not differ in great detail between the civil court and the PES. This result is in line with the partition shown in Figure 7. Moreover, the data show no significant difference between the numbers of male and female lay-offs. We do find differences with respect to firm size. Larger firms tend go to court more often. This is a novel finding, that is

\footnotetext{
${ }^{150}$ As mentioned earlier in Chapter 2, other options to terminate an employment contract are at will during the trial period, termination by mutual consent, termination by operation of law and by summary dismissal.

${ }^{151}$ For a more detailed overview of the difference between the separate procedures, we refer to Chapter 2 of this dissertation.

${ }^{152}$ Alternatively, workers can be exempted from paying income tax. The 1997 Alabama Severance Pay Exemption Act exempts the first $\$ 25,000$ of severance pay (including unemployment compensation, termination pay, or income from a supplemental income plan) received by an employee, who, as a result of "administrative downsizing" loses his or her job (quoted from http://ador.alabama.gov/incometax/esp.html).
} 


\section{CHAPTER 5}

in line with related research of other European countries (Bender, Dustmann, Margolis and Meghir (2002) for Germany and France; Boeri and Jimeno (2005) for Italy).

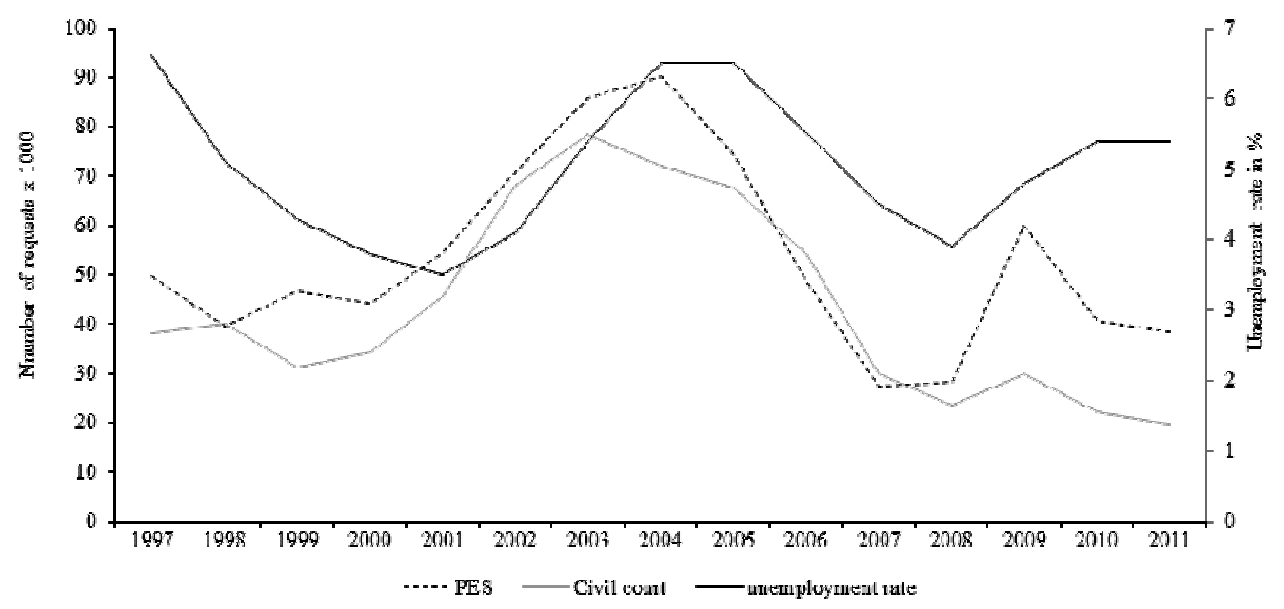

Figure 7 Duality of the Dutch labor market.

Table 2 presents information on the differences in duration of the dismissal procedures and some other job characteristics. T-test statistics and corresponding $p$-values that are reported show that all differences in means are significant. Differences in age and tenure between the two separate procedure are small though. The average age of an employee involved in a PES procedure and civil court procedure equal 44 years and 42 years, respectively. The tenure difference between the separate procedures is only one year. The duration of the civil court procedure is about three weeks shorter than the PES procedure. However, the variance of the court procedure duration is much larger. Employees involved in the civil court route earn higher wages than those involved in the PES route, both in terms of monthly wage and hourly wage. Moreover, the former groups works longer hours than the latter.

Table 1 Dismissals trough PES or civil court: Descriptives for the period 2006-2009 (continued on next page).

\begin{tabular}{lcccccc}
\hline & PES & \multicolumn{3}{c}{ Civil court } \\
\hline Likelihood of dismissal & $\mathbf{n}$ & $\%$ & $\mathbf{n}$ & $\%$ & Pearson $\boldsymbol{\chi}^{2}$ & p-value \\
Granted/dissolved & 994 & 87.65 & 878 & 93.21 & 17.89 & .00 \\
Non granted/not dissolved & 45 & 3.97 & 8 & 0.85 & 20.12 & .00 \\
Withdrawn & 95 & 8.38 & 56 & 5.94 & 4.51 & .03 \\
Total & 1,134 & 100 & 942 & 100 & & \\
\hline
\end{tabular}


Table 1 continued.

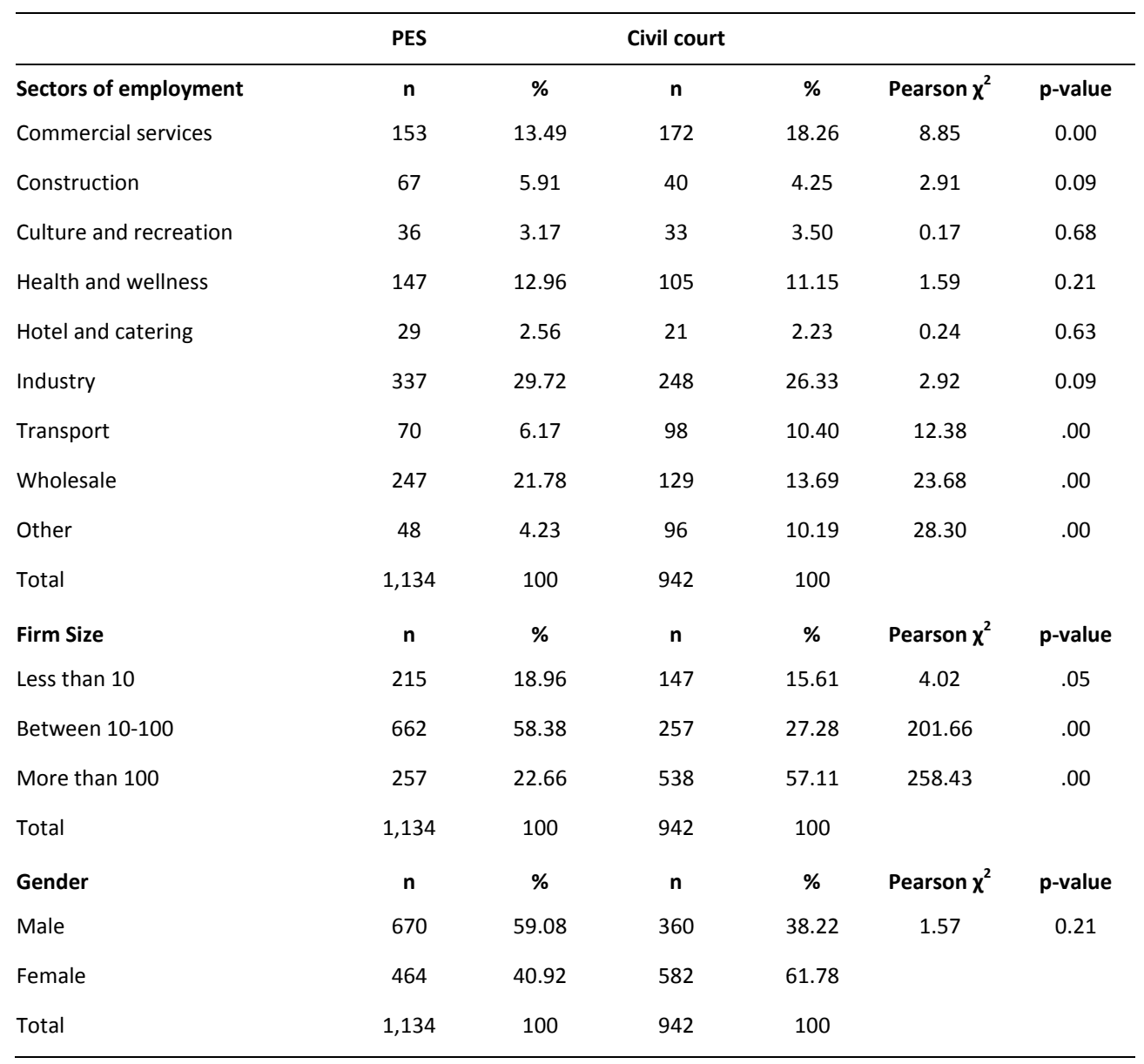

Table 3 gives an overview of the different reasons for which a dismissal has been requested. Distinctions are made between economic and non-economic reasons. Important economic reasons are long-term declines in sales or reduction in orders of production. Our data include 1,049 cases of lay-offs for economic reasons. The majority of dismissal requests being granted by the PES exist of job destructions for economic reasons. A smaller but not negligible amount of 21.9 percent of dismissal requests for economic reasons end up in court. Non-economic reasons are divided into dysfunctional behavior/disturbed relationship, reproachable behavior, illness, and a rest category. Almost all cases of prolonged illness are filed at the PES. Most other cases, mainly of disputes, are dealt with by the civil courts. A majority of firms successfully applies for permission to lay-off workers for economic reasons. We can compare the unconditional probabilities of permanent job destruction by the PES for economic reasons and of the non-economic reasons through court. The respective probabilities are 0.395 and 0.343 , and almost equal. The "off-diagonal" probabilities of non-economic dismissals approved by the PES and economic dismissals through court are, 0.152 and 0.111 , respectively, and also almost 
equal. These results corroborates with Figure 7 that the graphs for the PES and the civil court dismissals move along over the business cycle.

Since firms are relieved from the obligation of severance payment when the PES grants a dismissal request we argue that the PES is the institution that is responsible for severance pay exemption for firms that go through a period of economic contraction. The PES is instructed to judge whether a request for permission to dissolve a permanent worker contract is based on reasonable grounds. This preventative check of the PES is one of the most important disciplinary instruments currently available for the Dutch labor market. That is, it prevents firms in demise to seek a reduction of severance payments for unjustifiable reasons, and it reduces the costs of a firm's moral hazard to lay-off a worker at will imposed upon the Dutch society. In general, the concept of moral hazard implies that human beings will take risks if they have a reason to do so and ignore the moral implications of their choices. As an alternative, they will do what benefits them the most. More specifically, when a firm runs the risk of having to pay a high severance it has an incentive to lay off a worker at will on unjustifiable grounds, especially when being in economic distress. A preventative check does not allow an employer to do so. Additionally, the PES offers firms that are hit by a negative shock the option to dismiss an employee without the obligation of severance payment. Dismissals on unjustifiable grounds are rejected and costs of additional unemployment in recessions are avoided.

Table 2 Dismissals trough PES or civil court: Descriptives for the period 2006-2009.

\begin{tabular}{|c|c|c|c|c|c|c|c|}
\hline PES & $\begin{array}{c}\text { Duration in } \\
\text { monthst }\end{array}$ & Age & $\begin{array}{c}\text { Age } \\
\text { employed }\end{array}$ & $\begin{array}{l}\text { Tenure in } \\
\text { months }\end{array}$ & Hourly wage & $\begin{array}{l}\text { Monthly } \\
\text { wage }\end{array}$ & $\begin{array}{c}\text { Working } \\
\text { hours }\end{array}$ \\
\hline Mean & 1.11 & 44.72 & 33.65 & 132.85 & $€ 13.51$ & $€ 2,059.62$ & 31.79 \\
\hline Median & 0.82 & 45.00 & 32.64 & 96.48 & $€ 12.38$ & $€ 2,013.46$ & 36.02 \\
\hline St. Dev. & 1.01 & 9.97 & 10.28 & 104.83 & $€ 5.26$ & $€ 1,112.20$ & 9.81 \\
\hline Min & 0.00 & 17.00 & 15.59 & 1.81 & $€ 3.59$ & $€ 92.31$ & 2.13 \\
\hline Max & 10.16 & 70.00 & 65.45 & 513.44 & $€ 69.25$ & $€ 12,640.38$ & 50.00 \\
\hline Civil court & $\begin{array}{c}\text { Duration in } \\
\text { monthst }\end{array}$ & Age & $\begin{array}{c}\text { Age } \\
\text { employed }\end{array}$ & $\begin{array}{l}\text { Tenure in } \\
\text { months }\end{array}$ & Hourly wage & $\begin{array}{c}\text { Monthly } \\
\text { wage }\end{array}$ & $\begin{array}{c}\text { Working } \\
\text { hours }\end{array}$ \\
\hline Mean & 0.34 & 42.28 & 32.25 & 120.33 & $€ 16.35$ & $€ 2,654.92$ & 33.46 \\
\hline Median & 0.10 & 42.00 & 30.86 & 78.95 & $€ 13.97$ & $€ 2,250.01$ & 36.02 \\
\hline St. Dev. & 0.63 & 9.79 & 9.49 & 114.18 & $€ 8.48$ & $€ 1,741.27$ & 7.87 \\
\hline Min & 0.00 & 19.00 & 15.16 & 0.89 & $€ 6.85$ & $€ 222.24$ & 4.85 \\
\hline Max & 9.47 & 64.00 & 57.61 & 550.13 & $€ 86.64$ & $€ 17,128.79$ & 44.53 \\
\hline t-statistic $+\dagger$ & -27.48 & -5.60 & -3.12 & -2.60 & 8.93 & 9.07 & 4.30 \\
\hline$p$-value & .00 & .00 & .00 & .00 & .00 & .00 & .00 \\
\hline
\end{tabular}

TPES: The duration reported here is the difference between the date a case is taken into account and the date a case is closed. In Chapter 4 we reported the difference between the registration data and the closure date. Civil court: The duration is the difference between the registration date and the closure date.

++ For duration, age employed, hourly wage, monthly wage and working hours, we conducted a t-test assuming unequal variances (Satterthwaite's approximate t-test). For age and tenure we conducted a t-test assuming equal variances. 
Table 3 Reasons dismissal: Descriptive statistics and probabilities for the period 2006-2009.

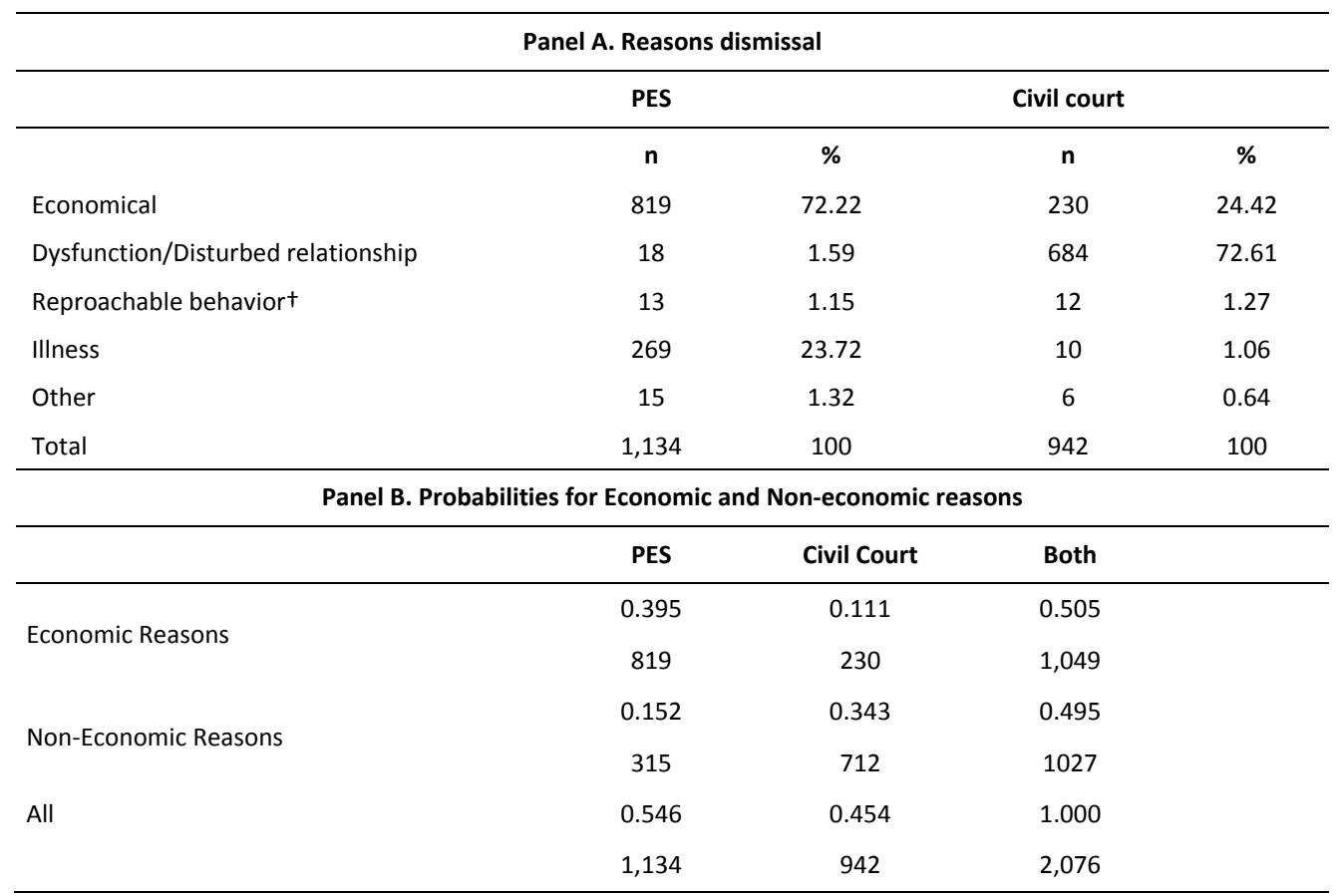

+ For civil court these cases include, theft, fraud and misconception. For PES we cannot make a distinction between different reproachable behavior cases.

\subsection{Some theoretical considerations}

In competitive labor markets government mandated severance payments are offset by optimal contracts between the worker and the firm (Lazear (1990), Acemoglu and Shimer (1999), Pissarides (2001)). Concerns about everlasting job shortage in modern labor markets challenged the equilibrium market model and induced the development of theories of labor market rigidities (Akerlof and Yellen (1985), Bentolila and Bertola (1990), Nickell (1997), Garibaldi and Violante (2005)). In a recent theoretical paper, Michaillat (2012) argues that in periods of contraction matching frictions, as in Mortensen and Pissarides (1994), are relatively unimportant. Job shortage can occur in equilibrium nevertheless and results from a combination of wage rigidity and diminishing marginal returns to labor. That being the case this chapter investigates the possibility that a government can intervene to overcome job shortage by securing jobs in recessions. For the economy as a whole Kaldor (1936) suggested a model of government intervention through wage subsidy to reduce unemployment. This chapter is the first to study this set up in the style of modern economics. We present a simple equilibrium model to investigate the possible effects of a specific government policy to secure jobs in firms that go through a period of economic downturn.

Consider a competitive labor market, where the costs of a firm to employ a worker are $w$ that includes a severance pay contribution $\tau$ to the government. $R(\ell)$ is the firm's revenue 


\section{CHAPTER 5}

function of a single input $\ell$, with $R^{\prime}>0$ and $R^{\prime \prime}<0$. In order to determine the optimum input $L^{*}$ given $w$ the firm's objective is to maximize the expected profit $E\left\{\Pi\left(L^{*}\right)\right\}$ with respect to $L^{*}$

(1) $\operatorname{Max}_{L^{*}} E\left\{\Pi\left(L^{*}\right)\right\}=\underset{L^{*}}{\operatorname{Max}}\left\{R\left(L^{*}\right)-w L^{*}\right\}$

The first order necessary condition yields

(2) $R^{\prime}=w$.

Solving (2) provides the unique solution for input $L^{*}$.

Severance pay exemption for a firm in demise

If the firm is relieved of the obligatory severance pay, then the wage costs will be lower. The firm's objective function changes into

(3) $\underset{L_{\tau}}{\operatorname{Max}} E\left\{\Pi\left(L_{\tau}\right)\right\}=\operatorname{Max}_{L_{\tau}}\left\{R\left(L_{\tau}\right)-w_{\tau} L_{\tau}\right\}$,

with $w_{\tau}=w-\tau$ The first order necessary condition is

(4) $R^{\prime}=w_{\tau} \quad$ or $\quad R^{\prime}=w-\tau$

Since, it holds that $\Delta w_{\tau}=w_{\tau}-w=-\tau$, it holds that $R^{\prime}\left(L_{\tau}\right)<R^{\prime}\left(L^{*}\right)$.

The probability of exemption

Now suppose that with probability $0<p_{\tau}<1$ a firm is granted exemption of severance pay. This case describes closest the situation for firms in the Netherlands. The firm's objective function then becomes

(5). $\operatorname{Max}_{L} E\{\Pi(L)\}=\operatorname{Max}_{L}\left\{p_{\tau}\left[R(L)-w_{\tau}\right]+\left(1-p_{\tau}\right)\left[R(L)-\left(w_{\tau}+\tau\right) L\right]\right\}$

The first order necessary condition is

(6) $p_{\tau}\left[R^{\prime}-w_{\tau}\right]+\left(1-p_{\tau}\right)\left[R^{\prime}-\left(w_{\tau}+\tau\right)\right]=0$.

Rewriting gives

(7) $\quad R^{\prime}=w-p_{\tau} \tau$ 
With $0<p_{\tau}<1$ it holds that $R^{\prime}\left(L_{\tau}\right)<R^{\prime}(L)<R^{\prime}\left(L^{*}\right)$, so that the marginal revenue in the case of a probable exemption of severance pay is lower than without that possibility (when $p_{\tau}=0$ ), but higher when no uncertainty exists and exemption is always granted (when $p_{\tau}=1$ ). $L$ is being chosen in advance of the state of nature being revealed. In the real world, of course actual firms have to make exactly such ex ante decisions.

The effect of severance pay exemption policy on revenues

In this section we investigate the effect of the severance pay exemption policy on the firm's total revenues. Let $R$ be a linear-quadratic revenue function of the firm with employment as the only input, $R(\ell)=(\alpha / \beta) \ell-(1 / 2 \beta) \ell^{2}$ with $\alpha, \beta>0$, so that $R^{\prime}(\ell)=(\alpha-\ell) / \beta$ for $\ell=L, L^{*}$

From equations (2) and (7) we get

(8) $\quad L^{*}=\alpha-\beta w$

and

(9) $L=\alpha-\beta w+\beta p_{\tau} \tau$.

Since $p_{\tau}>0$, we have $\Delta L \equiv L-L^{*}=\beta p_{\tau} \tau>0$, and therefore the firm's employment level is higher with the severance pay exemption policy than without.

The change in employment that results from the severance pay exemption policy is -positively -- related to three parameters. The first parameter is the severance pay rate, $\tau$. The effect of the exemption policy will be larger when the severance pay rates are higher. The second parameter is the probability of exemption, $p_{\tau}$. An increase of the exemption probability renders the exemption policy more effective to secure jobs. The third parameter is $\beta$, the slope of the demand curve. If labor demand is highly elastic (flat demand curve, $\beta$ is small), then the effect of the policy will be small ( $\Delta L$ will be small). If labor demand is inelastic the effect of the policy will be large. This is a surprising result. It holds true because in equation (9) $\beta$ determines the slope as well as the intercept of the demand curve.

The firm's expected revenues are always higher with the severance pay exemption policy than without. This can be shown as follows. Define $\Delta R \equiv R(L)-R\left(L^{*}\right)$. Subtracting equation (9) from (8) gives $\Delta R=\beta\left(\left(w p_{\tau} \tau-1 / 2\left(p_{\tau} \tau\right)^{2}\right)\right.$. So $\Delta R>0$ iff $w>1 / 2 p_{\tau} \tau$. Since $w=w_{\tau}+\tau$, $w_{\tau}>0$, and $0<p_{\tau}<1$, the inequality $w>1 / 2 p_{\tau} \tau$ always holds and therefore $\Delta R>0 .{ }^{153}$

The responsiveness of the firm to the exemption policy can be investigated in more detail in the following way. Define $\eta$ as the wage elasticity of labor demand between the two regimes with and without the probability for a firm to receive severance pay exemption. Then

$$
\eta=\frac{\Delta L}{L} / \frac{\Delta w_{\tau}}{w_{\tau}}
$$

\footnotetext{
${ }^{153}$ Similarly, the firm's expected profits are higher with the severance pay exemption probability than without.
} 


\section{CHAPTER 5}

With $\Delta w_{\tau}=-\tau$, so that $\eta<0$. Let $v>0$ be the unemployment benefit per worker paid by the government and let $\rho \equiv v / w_{\tau}$ be the replacement ratio. The equilibrium condition for the exemption policy to be effective is that the costs for the government are equal in both regimes. Without the policy the government receives from the firm severance payments $\tau L^{*}$. In case of an exemption the government receives zero severance payments, but saves $v \Delta L$ on unemployment benefits. The equilibrium condition can be written as

(10) $\tau L^{*}=v \Delta L, \quad$ or $\quad \tau(L-\Delta L)=v \Delta L$.

Given that $\Delta L>0$, we write

(11) $v=\tau\left(\frac{L}{\Delta L}-1\right)$

Combining equations (9) and (11) yields

(12) $v+\tau=-\frac{w_{\tau}}{\eta}, \quad$ or $\quad \eta=-\left(\rho+\frac{\rho_{\tau}}{w_{\tau}}\right)^{-1}$

From this we conclude that a necessary condition is $-\rho^{-1}<\eta<0$, or in absolute terms

$|\eta|<\left|\rho^{-1}\right|$. In this simple model of linear demand and linear-quadratic revenue functions with employment as the only input we find that in order for the severance pay exemption policy to be effective and cost-conscious the wage elasticity of labor demand should not exceed the inverse of the replacement ratio. A system of severance payment exemption is less costly than the alternative of additional unemployment benefits as long as the wage elasticity of labor demand does not exceed the inverse of the replacement ratio. Let's assume generously that the replacement ratio is .75 , so that its inverse is 1.33 . Generally, the full (substitution and scale elasticity) labor-demand elasticity in absolute terms is one or below (Hamermesh, 1996).

\section{The effect of a negative shock}

The wage elasticity of labor demand increases (less negative, closer to zero) with the size of the shock. This can be shown as follows. Let $\tilde{\eta}$ be the wage elasticity of labor demand after a negative shock that shifts the demand curve inwards. Given that $\Delta \widetilde{w}=\Delta w=-\tau, \Delta \widetilde{L}=\Delta L$, and $\widetilde{L}^{\prime}=L^{\prime}$, it holds that

$\frac{w_{\tau}}{L}<\frac{\widetilde{w}_{\tau}}{\widetilde{L}}$, and therefore that $\frac{\eta}{\widetilde{\eta}}=\frac{w_{\tau}}{L} / \frac{\widetilde{w}_{\tau}}{\widetilde{L}}<1$, so that $\eta<\widetilde{\eta}$, or in absolute terms $|\eta|>|\widetilde{\eta}|$

This result states that the likelihood that the necessary condition -- that the wage elasticity of labor demand does not exceed the inverse of the replacement ratio -- holds increases during 
recessions, when more firms are hit by downward shocks. ${ }^{154}$ Consequently, the severance pay exemption policy is more effective during periods of recession. ${ }^{155}$

Estimate for the transfer probability $p_{\tau}$

An estimate for the transfer probability $p_{\tau}$ can be obtained from Table 4: $p_{\tau}=$ $(819 / 1134) /[(230 / 942)+(819 / 1134)]=0.75$. Three out of four permanent contract jobs that are terminated for economic reasons receive approval from the PES. The fourth ends up in court.

\subsection{Conclusion}

Severance pay lenience is one the most important disciplinary instruments currently available for Dutch labor market policy. Preventive dismissal checks restrain firms to seek reduction of severance payments on unjustifiable grounds. Consequently, firms are discouraged to shift private costs to society on considerations of self-interest alone. The possibility to grant permission for dismissal of tenured workers by the PES reduces moral hazard in the labor market when firms go through bad times.

The analysis of a simple general equilibrium model shows that in order for severance pay exemption policy to be effective and cost-conscious the wage elasticity of labor demand must not exceed the inverse of the replacement ratio. Then a labor market policy with severance payment exemption is less costly than the alternative of additional unemployment benefits. Moreover, the policy is more effective during periods of recession.

Our study uses the tools from modern micro- and labor economics to analyze job security provision and social insurance policies in times of economic recession. The equilibrium policy analysis presented in this paper leaves ample ground for extension, specialization, and generalization. For example, in line with Michaillat (2012) we assumed that in times of economic downturn there is excess labor supply, so that demand determines the level of employment. One of the most imperative steps to take next is to design a dynamic general equilibrium search model as in Landais, Michaillat and Saez (2012). Such a model extended with cyclical severance pay exemption governmental policy is necessary for sensitivity analysis of the critical assumptions and to perform analyses of the influence of government policy on job protection during periods of economic expansion and recession separately.

\footnotetext{
${ }^{154}$ This theoretical result is also supported empirically. Drazen, Hamermesh and Obst (1984), for example, find that during recessions the demand elasticity is found to be closer to zero.

${ }^{155}$ A negative shock can be so large, that $L<0$ and the firm would go bankrupt unless the government is willing to make a contribution to the firm and jobs might be saved. In our model this implies that temporarily $\tau<0$. This was in fact the situation in the Great Recession of 2008-2009 when the Dutch government helped saving private banks such as Fortis, Aegon, ABN-AMRO and ING with large financial injections.
} 

CHAPTER 6:

RECESSION INDUCED REQUESTS AND THE LIKELIHOOD OF SUCCESS 


\subsection{Introduction}

Two employees that perform equally well should have the same likelihood of being dismissed. From a normative point of view, employers should not be influenced by the state of the economy in their decision to fire an employee. In practice, both Siegelman and Donohue III (1995) and Ichino, Polo and Rettore (2003) provide evidence that the decision to file a dismissal case is not only dependent on the severity of the misconduct, but also on the state of the economy. They discovered that recession induced cases are weaker than cases that are filed in economic booms.

The Dutch system is different from the Italian and the US dismissal system discussed in the studies of Ichino et al. and Siegelman and Donohue III. Because the Netherlands applies a preventative check of dismissal, the plaintiff is the employer and the defendant is the employee. In both Italy and the US a repressive check exists, implying that the role of plaintiff and defendant are reversed; the plaintiff is the employee, the defendant the employer. Furthermore, unlike Italy and the US, and most other countries, the Netherlands has two institutes responsible for the enforcement of employment protection laws. When intending to terminate a permanent employment contract, the employer may request the public employment service (PES) ${ }^{156}$ to dissolve the employment contract, or he may ask the universal civil court to dissolve the contract. Both routes apply a different set of laws (see Chapter 2).

This chapter shows that the number of PES dismissal requests and number of civil court dismissal requests increases with increasing unemployment rates. This holds true for both economic and noneconomic requests. The aim of this chapter is to test if the recession induced cases that we observe in the Dutch system exhibit the same characteristic as the recession induced cases observed by Ichino et al. and Siegelman and Donohue III. If exhibiting the characteristic of being of lower quality, cases that are filed in recessionary periods should have a larger likelihood of being rejected. Using a novel data set, this paper tries to answer the following research question. Are recession induced cases that are filed at the PES and the civil court relatively weaker cases? In the Netherland, a written set of employment protection laws determine under which conditions dismissal is fair. We define a weaker case as a case that does not, partly or fully, comply with the definition of a fair dismissal as stipulated in the Dutch code of law.

We show that recession induced PES dismissal request are less likely to be won by the employer. Under the assumption that judicial decision making is independent of the state of the economy, we provide evidence that recession induced cases are weaker. These results are desirable because they imply that the PES does not allow an employer to terminate a permanent employment contract without a reasonable cause. For the civil court we do not find evidence that recession induced cases are weaker.

The structure of this chapter is as follows. Section 2 present a short overview of Dutch legislation. Only the most important aspects of law are discussed, for a more detailed description of law see Chapter 2 of this dissertation. Section 3 proceeds with a theoretical

\footnotetext{
${ }^{156}$ PES is used as an acronym for public employment service. The official Dutch name for the public employment service (PES) is Uitvoeringsinstituut WerknemersVerzekeringen (UWV). The subsidiary responsible for handling dismissal requests is the UWVwerkbedrijf. Troughout this chapter we will use the acronym PES.
} 
framework in which hypothesis are presented. Section 4 shows data and results. In Section 5 the implications of our results are discussed. Last, Section 6 concludes.

\subsection{Legal background}

The Netherlands, unlike other countries, has two institutes enforcing employment protection legislation (EPL); the public employment service (PES), and the civil court. Both institutes perform an a priori check of dismissal. This implies that, before dismissing a worker, an employer needs to request the PES for a dismissal permission or he may ask the court to dissolve the employment contract. ${ }^{157}$ This section briefly explains the Dutch EPL. It only highlights those rules that are applicable in this chapter. For a more detailed overview of the Dutch employment protection legislation (EPL) ${ }^{158}$ system, see Chapter 2 of this dissertation.

PES. The PES is an administrative public body that operates under close supervision of the government. ${ }^{159}$ In order to judge whether dismissal is fair, the PES consults the policy rules governed by the Dismissal Decree (DD). A fair dismissal is a dismissal that is able to fulfill all criteria that are stipulated in the DD. The list of criteria that should be met is different for different dismissal reasons. Fair dismissals are dismissals based on economic grounds (e.g. redundancy), dysfunctional behavior, a disturbed employment relationship, illness and misconduct. A dismissal request needs to be substantiated with detailed evidence. ${ }^{160}$ If the PES judges dismissal to be fair, dismissal permission is given. Employees who are dismissed via the PES are not awarded a severance payment.

Civil court. The civil court is an independent legal body. Rules and regulations regarding the rescission of the employment contract by court are recorded in the Civil Code. ${ }^{161}$ The civil court may dissolve the contract for substantial reasons. A substantial reason is a circumstance that would have also allowed for an immediate dismissal. Examples are fraud, incompetence, drunkenness, theft and reckless behavior. A substantial reason also refers to a circumstantial change that justifies the termination of an employment relationship. Examples are financial distress, disturbed employment relationship, employee dysfunctional behavior and illness. If an employment contract is rescinded because of a change in circumstances, the civil court may oblige the employer to pay severance payment. The amount is stated in a civil court guideline and equals $A \times B \times C$, where factor $A$ is the weighted years of service. The older the employee,

\footnotetext{
${ }^{157}$ Next to termination by dismissal, an employment contract may also be terminated by mutual consent and by the expiration of a fixed term contract, on the expiration of an agreed upon period. Other options are termination of the contract during the trial period and immediate dismissals. An estimation of the distribution of dismissal cases over the different termination options is given by a research conducted in 2001 (Research and Beleid, 2001). This research indicates that in $42 \%$ of all cases termination of an employment contract occurs because of the expiration of a fixed term contract. $5 \%$ is termination by mutual consent. $14 \%$ of cases follows either the PES (7\%) or the civil court procedure (7\%).

${ }^{158}$ In this chapter EPL is used as an acronym for employment protection legislation.

${ }^{159}$ The minister of Social Welfare and Employment is authorized to grant dismissal approval and has delegated this authority to the PES. The PES is supposed to report to the Minister on how the authority to grant dismissal approval is practiced.

${ }^{160}$ For a detailed description of these criteria, see the Beleidsregels Ontslagtaak UWV, UWV (2012).

161 The provisions of the Civil Code do not apply to persons employed by a public body, unless agreed-upon otherwise by both parties, before or on initiation of the employment relationship, either by law or by ordinance.
} 
the more weight is attached to his or her years of service. ${ }^{162}$ Factor B is the gross monthly salary, including fixed components such as holiday pay. Factor $C$ is a correction factor that is determined by the civil court. Factor $C$ usually equals 1 , but may be fixed at a higher or a lower level.

One can distinguish between two type of civil court dismissal cases. The first is a contradiction case. A contradiction case is a case of mutual disagreement: the employer intends to dismiss the worker but the worker does not agree about being dismissed, about the terms of dismissal, or both. Both parties are heard during an oral session after which the court decides about the outcome of the dismissal dispute. The second type of case is a non-contradiction or pro-forma case. The outcome of a pro-forma case is mutually agreed upon by the employer and the employee and is already known before turning to court. Preceding the court procedure, agreements are made about the date of termination and the severance payment that will be awarded to the dismissed employee. The court has no incentive not to follow the agreements made. Before the $1^{\text {st }}$ of October 2006, non-contradiction procedures were mainly followed to safeguard the payment of unemployment benefit. Before the $1^{\text {st }}$ of October 2006, the Dutch social security system did not award unemployment benefit to a worker whose contract was terminated with the worker's consent. Since October 2006 this no longer holds true. Today, non-contradiction procedures are followed to safeguard agreements made. In the years 20032009 approximately $80 \%$ of all civil court cases in the Netherlands were non-contradiction cases. $^{163}$

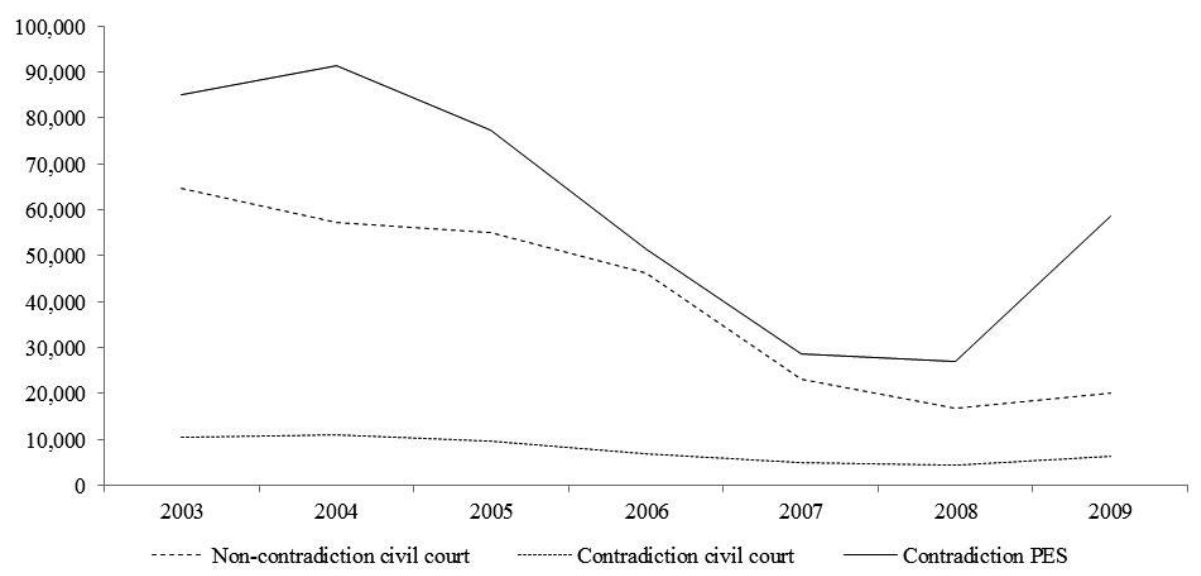

Figure 1 Contradiction versus non-contradiction cases. The total Netherlands (2003-2009).

\subsection{Theoretical background}

Figure 2 and Figure 3 show the relation between the number of dismissal requests filed at the $\mathrm{PES}$ and the civil court, respectively, and the unemployment rate. Both figures distinguish

\footnotetext{
${ }^{162}$ The years of service up to the age of 40 are counted as one month's salary, from 40 to 50 as 1.5 and after 50 as 2 .

${ }^{163}$ We obtained this information from the Raad voor de Rechtspraak (2010).
} 
between economical and non-economical dismissals. Furthermore, Panel A shows actual numbers per month obtained from the sample data collected. For a more detailed overview of this data see Chapter 3 of this dissertation. Panel B shows 3-month moving averages to smooth out small-term changes and to highlight a longer term trend. Both figures show that the number of total request moves together with the unemployment rate. The same holds true for the number of economic request. This simultaneous movement with the unemployment rate is less visible for the number of noneconomic dismissal, especially at the PES. Correlations, however, show that both the number of economic admissions and the number of non-economic admission are positively correlated with the unemployment rate. This holds true for both the PES route and the civil court route, see Table 1 for an overview of correlations.

Table 1 The unemployment rate and number of dismissal request, correlations (based on total sample, PES $n=1,162$, civil court $n=2,390)$.

\begin{tabular}{lcc}
\hline & $\mathbf{r}$ & p-value. \\
\hline Total dismissals PES & .342 & .017 \\
Economic dismissals PES & .349 & .015 \\
Non-economic dismissals PES & .322 & .026 \\
Total dismissals civil court & & .007 \\
Economic dismissals civil court & .282 & .006 \\
Non-economic dismissals civil court & .288 & .008 \\
\hline
\end{tabular}

From an economic perspective, a simultaneous increase of the number of economic dismissal and the unemployment rate is expected since firms in economic distress are forced to lay-off workers. An increasing number of non-economical request when the economy is down seems less straightforward. At the PES, noneconomic dismissal are mainly cases in which the employee concerned is ill. At the civil court, these noneconomic cases are mostly filed due to a disturbed relationship. From a normative point of view, being ill or performing badly should not be dependent on the state of the economy. In a different setting than the Dutch setting, however, we have already seen that a weak economy elicits an increase in the number of dismissal cases. Siegelman and Donohue III (1995) show that the number of employment discrimination disputes filed at court rise with the unemployment rate. They provide evidence, however, that the cases filed during recessions tend to be of weaker quality than those filed during nonrecessionary times. An equal finding is presented by Ichino et al. (2003) as they show that in regions where unemployment is high, the gravity of the cases going to trial tends to be higher than in other regions. In both the study of Ichino et al. and the study of Siegelman and Donohue III, the worker is the plaintiff and the employer the defendant. As such, their research concludes that the average plaintiff's case is weaker in economic downturns than in economic upturns. We hypothesize that the recession induced cases that we observe in the Dutch system exhibit the same characteristic. If so, cases that are filed in recessionary periods have a larger likelihood of being rejected. Hence, we propose the following hypotheses:

H1: The likelihood that dismissal permission is granted by the PES decreases with increasing unemployment rates. 
H2: The likelihood that the employment contract is dissolved by the civil court decreases with increasing unemployment rates.

These hypotheses are in line with results of Siegelman and Donohue III that show that recession induced cases are less often won by plaintiffs, simply because of the fact that they are of lower quality. ${ }^{164}$ Ichino et al. actually find that despite of the lower quality of recession induced cases, courts still decide in favor of the plaintiff. The authors argue that this is due to the fact that the legal standards of courts in Italy are influenced by unemployment. Different from Ichino et al., we make the simple assumption that Dutch law defines such a narrow grid of prescriptions, so that there is no room for the judge to be influenced. In other words, under Dutch law the decision to terminate an employment contract is not dependent by any other factors than the severity of the dismissal case alone.

\subsection{Data and results}

In order to test our hypotheses, we use a unique dataset that is collected at the civil court and the PES. The complete data set we collected contains 1,162 PES dismissal cases and 2,390 civil court cases (See Chapter 3 and Appendices $C$ and $D$ ). In order to conduct this analyses only part of the original data set is selected. Our definition of a dismissal cases is a dismissal dispute in which an employee requests for dismissal permission of one of his permanent employees. Hence, fixed term contracts and employees that have requested for the rescission of the contract are excluded. Furthermore, because our interest is in analyzing the decision of the judge, withdrawn cases and non-contradiction cases are left out. With respect to the PES alone, collective cases involving more than 19 employees are moreover excluded. ${ }^{165}$ As a result, the data used in this chapter contains 823 PES dismissal cases over the period 2006-2009 and 404 civil court dismissal cases over the year 2003-2009. In our data, each case represents one individual employee and one individual firm.

\footnotetext{
164 The theoretical explanation for this finding is that when the unemployment rate rises, the duration of unemployment spells increases, which prompts for higher damages awarded when the employment discrimination case is won. These higher damage pays increase the expected value of a case and could induce low probability cases to file suit. The theoretical explanation for this finding is that when the unemployment rate rises, the duration of unemployment spells increases, which prompts for higher damages awarded when the employment discrimination case is won. These higher damage pays increase the expected value of a case and could induce low probability cases to file suit.

${ }^{165}$ Collective dismissals concerning more than 20 employees are excluded, because in all collective cases in our dataset dismissal permission is granted. The level of analysis in our data set is the individual case.
} 
Panel A Unemployment versus monthly amount of dismissal requests.

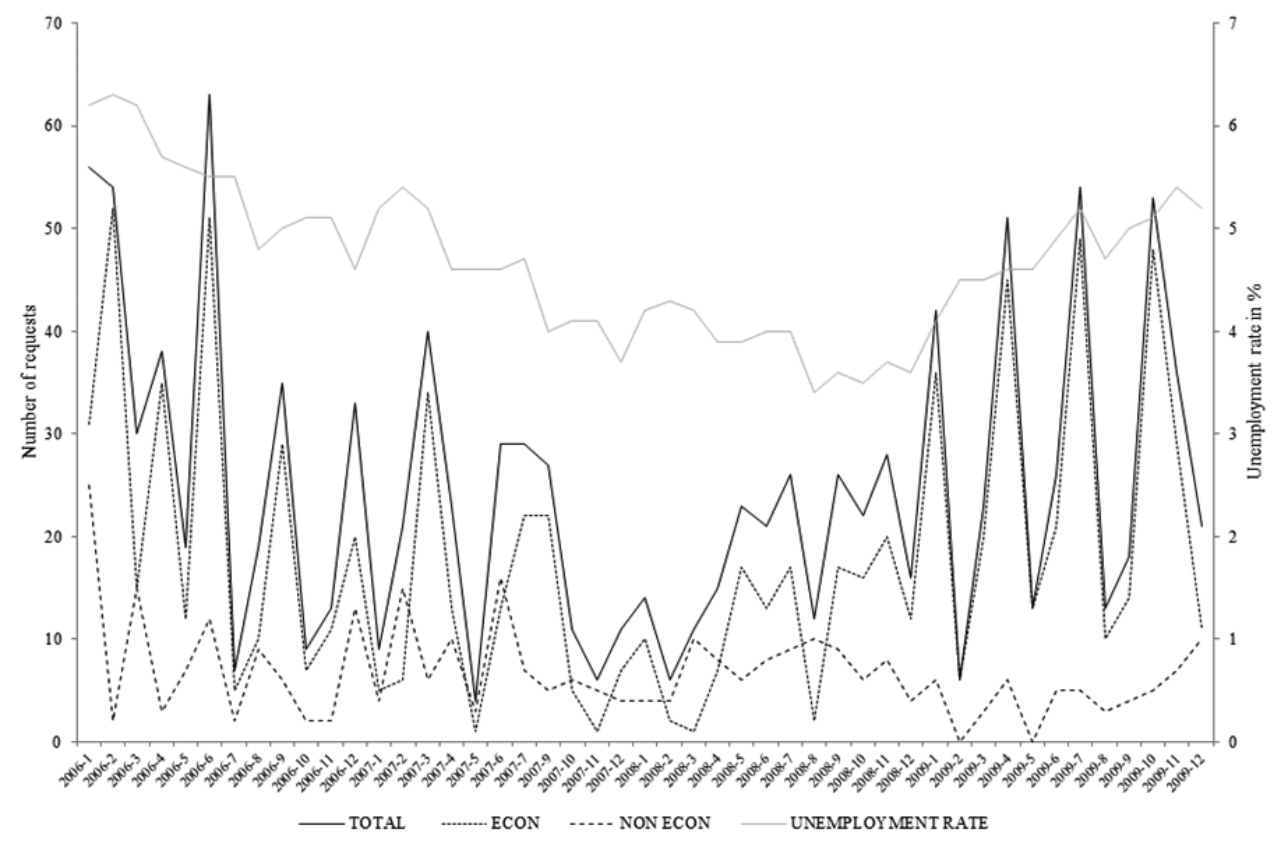

Panel B Unemployment versus 3-month moving average of number of monthly dismissal requests.

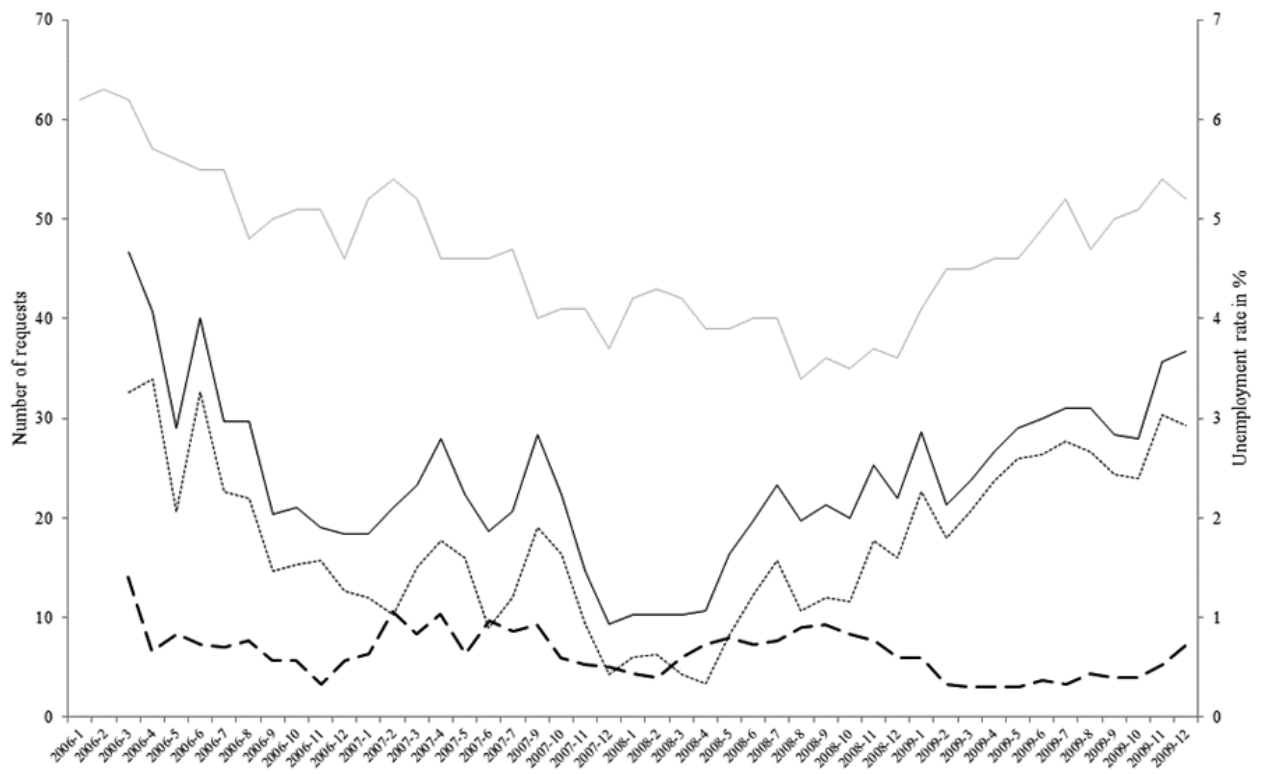

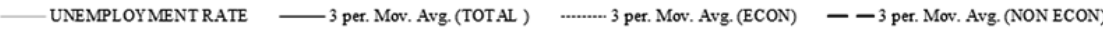

Figure 2 The unemployment rate and number of dismissal request (PES, 2006-2009, n=1,162 total sample). 


\section{CHAPTER 6}

Panel A Unemployment versus monthly amount of dismissal requests.

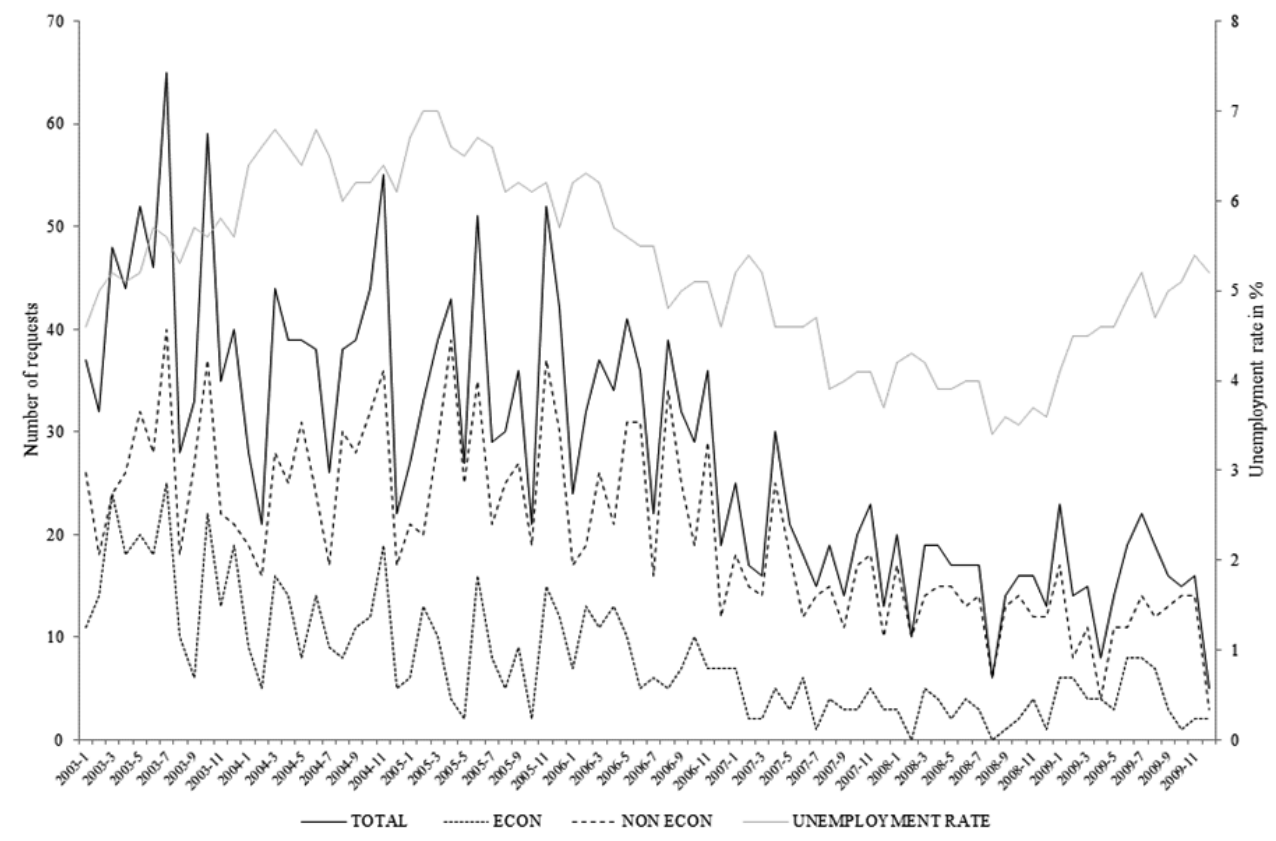

Panel B Unemployment versus 3-month moving average of number of monthly dismissal requests.

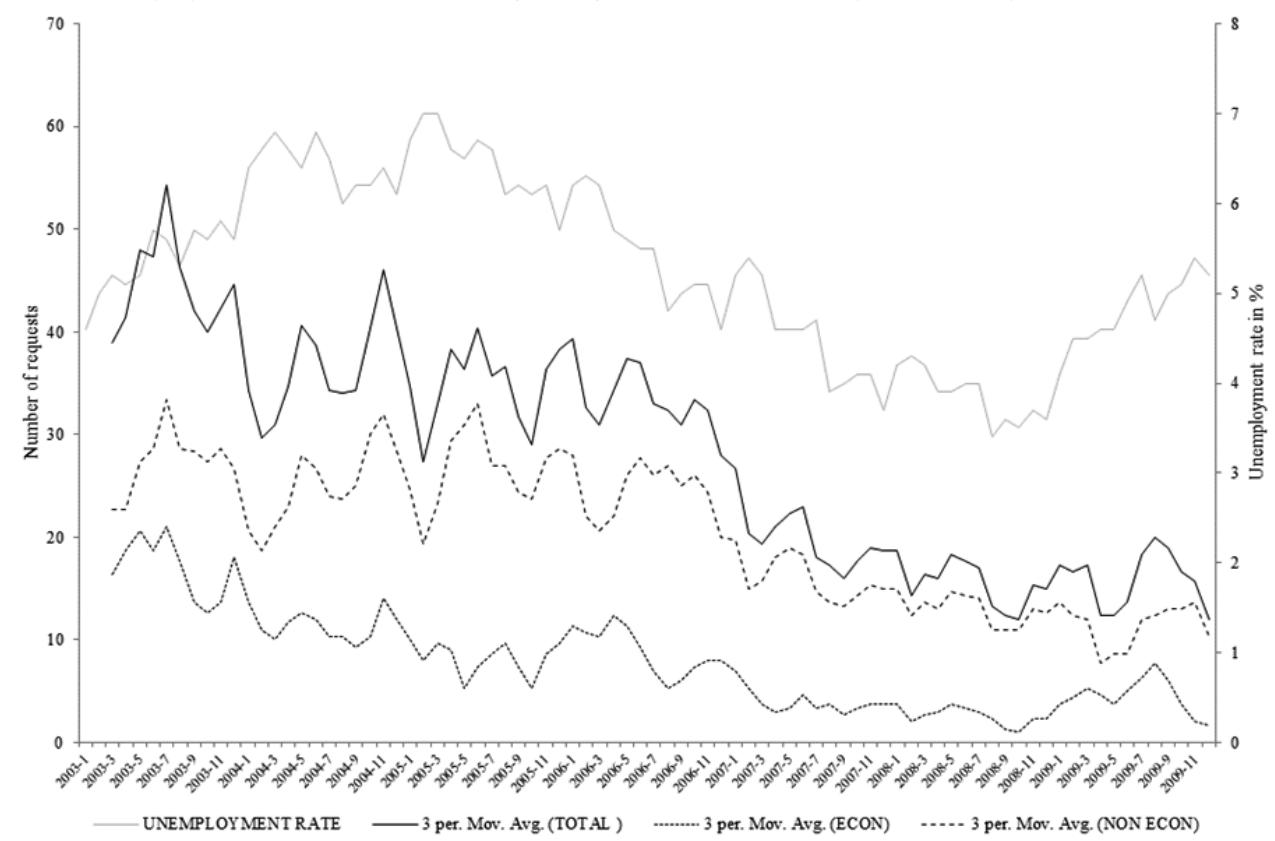

Figure 3 The unemployment rate and number of dismissal request (Civil court, 2003-2009, n=2,390 total sample). 


\subsubsection{Hypothesis 1}

In order to test hypothesis 1 , we use the PES data containing 823 dismissal cases that were filed at the PES in the period 2006-2009. Unemployment rates are adjusted for seasonality. ${ }^{166}$ Table 2 gives an overview of all variables used and a description of those variables. Descriptive statistics are shown in Table 3 and Table $4 .{ }^{167}$ The average unemployment rate in the PES sample presented in this chapter equals $4.76 \%$ (Table 3). As seen in Figure 2, unemployment levels were highest in the beginning of the year 2006, decreased until 2008 and started peaking again in 2009. With respect to the decision of the PES, 5 percent out of all request is granted. Furthermore, 64 percent of all dismissals is based on economic grounds.

Next, we fit a maximum likelihood probit model that explains whether dismissal permission is granted by the PES or not:

$$
\operatorname{Pr}(\text { permission not granted }=1)=\varnothing\left(\beta_{0}+\beta_{1} U N E M P L+\beta_{2} E C O N+\beta_{3} D U R+\beta_{4} Q+\beta_{5} R+\beta_{6} S\right)
$$

where $\varnothing$ is the cumulative normal distribution. The independent variable is a dichotomous variable that indicates whether dismissal permission is granted or not (DISNGR; 1=not granted, $0=$ granted). UNEMPL is the adjusted unemployment rate and ECON stands for economic dismissals. DUR is the duration of dismissal. Furthermore, $Q$ is a set of variables that indicates whether parties receive legal assistance (EMPEONL, EMPRONL, BOTH, NOASSIS). $R$ is a set of employee specific variables, such as Tenure (TEN), Age (AGE), Gender (MAN), Hourly wage (HOURW) and Working hours per week (WHOURS). Last, $S$ includes the employer specific characteristics Industry (INDUS), Legal form (LIML, FOUND, OTHERL) and Size (LESS10, BT10-100, MORE100).

Table 5 presents the probit analyses with marginal effects $(\partial \emptyset / \partial x)$ at the means of all continuous variables $(x=\bar{x})$. For the dichotomous variables, $\partial \varnothing / \partial x$ is for a discrete change of the dichotomous variable from 0 to 1 . First, we included all variables as specified in our model above in Model 1. All employee-specific variables, the industry dummies, the quarterly dummies and employer size dummies, however, have an insignificant effect. Furthermore, the legal form dummies fail to significantly affect our dependent variable. ${ }^{168}$ These findings indicate that the likelihood that dismissal permission is refused is not dependent on the wage, the tenure, the

${ }^{166}$ First, we adjusted the total unemployed working population and the total working population for seasonality:
1a) $W P_{t}=\sum_{i=1}^{s} \beta_{i} D_{i t}+e_{t}$
2a) $U W P_{t}=\sum_{i=1}^{s} \beta_{i} D_{i t}+e_{t}$
1b) $W P A D J_{t}=\overline{W P}+e_{t}$
$2 b)=\overline{U W P}+e_{t}$

Second, we calculated the adjusted unemployment rate by dividing the adjusted total unemployed working population by the adjusted total working population:

3) $U N E M P L A D J_{t}=\frac{U W P A D J_{t}}{W P A D J_{t}}$

${ }^{167}$ With respect to the descriptive statistics, different chapters of this dissertation present different numbers. This is due to the fact that different selections were made, depending on the purpose of the analysis.

${ }^{168}$ The Wald test statistic for the joint significance of FOUND and OTHERL equals 4.32, with corresponding $p$-value of 0.12 . 
age or the gender of an employee. Neither are the characteristics of an employer important in the decision of the PES to refuse dismissal permission. From a normative point of view, these findings reflect an enforcement of law that is desirable; employees nor employers that possess certain characteristics are being discriminated or given preference to. When excluding the set of employee-specific variables $R$ and set of employer-specific variables $S$ from Model 1 , a more efficient model is achieved. ${ }^{169}$ The coefficient of the unemployment rate (UNEMPL) equals 0.02 and is significant at a 5 percent level $(p=0.040)$. This implies that a 1 percent increase in the unemployment rate leads to a $2 \%$ increase in the likelihood that dismissal permission is refused. Under the assumption that the decision process of the PES is an exogenous decision process, this result provides evidence that recession induced cases are of lower quality and allows for the acceptance of hypothesis 1 . An additional result obtained from the probit analysis is that in cases where only the employee receives legal assistance (EMPEONL), the likelihood that dismissal permission is refused is higher than in cases where none of the parties receive legal help (NOASS). Results are insignificant for cases in which only the employer (EMPRONL) is assisted, or when both parties are assisted (BOTH). Last, the variable that indicates whether dismissal is based on economic grounds (ECON) is negative, but insignificant at a 5 percent level.

Table 2 Description of variables, Hypothesis 1, PES data (continued on the next page).

\begin{tabular}{|c|c|c|}
\hline Variables & Abbreviation & Description \\
\hline \multicolumn{3}{|l|}{ Dependent variable } \\
\hline Dismissal not granted & DISNGR & $\begin{array}{l}\text { This variable indicates whether PES has not granted dismissal } \\
\text { permission (dichotomous) - only available for the PES }\end{array}$ \\
\hline \multicolumn{3}{|l|}{ Continous variables } \\
\hline Unemployment rate & UNEMPL & $\begin{array}{l}\text { The monthly unemployment rate for the total Netherlands is adjusted } \\
\text { for seasonality and calculated by dividing the total unemployed } \\
\text { working population in the Netherlands by the total working population } \\
\text { in the Netherlands. }\end{array}$ \\
\hline $\begin{array}{l}\text { Duration procedure in } \\
\text { months }\end{array}$ & DUR & $\begin{array}{l}\text { Duration of the PES procedure, this is the time in between the } \\
\text { registration date of the dismissal and the date of the PES decision. }\end{array}$ \\
\hline Age & AGE100 & Age in years divided by 100 . \\
\hline Tenure in months & TEN100 & Tenure in months divided by 100. \\
\hline Hourly wage & HOURW & $\begin{array}{l}\text { Hourly wage of the employee, excluding holiday pay and additional } \\
\text { fees. }\end{array}$ \\
\hline Working hours per week & WHOURS & Number of working hours per week of the concerned employee. \\
\hline \multicolumn{3}{|l|}{ Categorical variables } \\
\hline Economic dismissal & ECON & $\begin{array}{l}\text { Reason for dismissal as indicated by the employer. ECON stands for } \\
\text { economic dismissals (dichotomous) }\end{array}$ \\
\hline Non-economic dismissal & NONECON & $\begin{array}{l}\text { Reason for dismissal as indicated by the employer. NONECON stands } \\
\text { for non-economic dismissals (dichotomous) }\end{array}$ \\
\hline $\begin{array}{l}\text { Legal assistance only for } \\
\text { employee }\end{array}$ & EMPEONL & $\begin{array}{l}\text { This variable indicates that only the employee receives legal assistance } \\
\text { - only available for the PES (dichotomous). }\end{array}$ \\
\hline
\end{tabular}

\footnotetext{
${ }^{169}$ The LR-test comparing model 1 tot model 2 , which is the null model in our case, produces a $\chi^{2}$ value of 12.75 (sig.=0.82).
} 
Table 2 continued.

\begin{tabular}{|c|c|c|}
\hline Variables & Abbreviation & Description \\
\hline $\begin{array}{l}\text { Legal assistance only for } \\
\text { employert }\end{array}$ & EMPRONL & $\begin{array}{l}\text { This variable indicates that only the employer receives legal assistance } \\
\text { - only available for the PES (dichotomous). }\end{array}$ \\
\hline $\begin{array}{l}\text { Legal assistance for both } \\
\text { employer and employee }\end{array}$ & BOTH & $\begin{array}{l}\text { This variable indicates that both the employer and the employee } \\
\text { receive legal assistance - only available for the PES (dichotomous). }\end{array}$ \\
\hline No legal assistance & NOASSIS & $\begin{array}{l}\text { This variable indicates that neither the employer nor the employee } \\
\text { receive legal assistance - only available for the PES (dichotomous). }\end{array}$ \\
\hline Industry & INDUS & $\begin{array}{l}\text { The industry in which the employer operates (dichotomous variables } \\
\text { for the different industries). }\end{array}$ \\
\hline Less than 10 employees & LESS10 & Size of firm (dichotomous). \\
\hline $\begin{array}{l}\text { Between } 10 \text { and } 100 \\
\text { employees }\end{array}$ & BT10-100 & Size of firm (dichotomous). \\
\hline More than 100 employees & MORE100 & Size of firm (dichotomous). \\
\hline Gender & MAN & $\begin{array}{l}\text { This variable indicates whether the employee is male or female } \\
\text { (dichotomous) }\end{array}$ \\
\hline Limited liability & LIML & Legal form the employer holds (dichotomous). \\
\hline Foundation & FOUND & Legal form the employer holds (dichotomous). \\
\hline Other & OTHERL & Legal form the employer holds (dichotomous). \\
\hline Quarterly & Q & $\begin{array}{l}\text { These are variables that indicate the different quarters in the year } \\
\text { (dichotomous). }\end{array}$ \\
\hline
\end{tabular}

+ We made the assumption that employers that employ more than 100 employees, have access to legal support, either internally or externally

\subsubsection{Hypothesis 2}

In order to test hypothesis 2, we use the civil court data with 404 contradiction cases. As mentioned earlier, non-contradiction cases and withdrawn cases are excluded. Table 6 reports all variables used and a description of those variables. Descriptive statistics are shown in Table 7 and Table 8. Table 7 shows that the mean unemployment rate of 6 percent is higher for the civil court data than for the PES data. This is due to the fact that, the civil court data covers a larger time period.

We mentioned before in Chapter 4 that the likelihood that the civil court does not dissolve the employment contract is very small. Less than $1 \%$ is rejected. If we however, exclude proforma or non-contradiction cases, the number of intended dismissals that is put to a halt by civil court is even larger than at the PES route of dismissal. Table 8 shows that out of 404 request, 7,5 percent got rejected by the court. These findings provide us with some new insight because it is a common belief that the likelihood of success is larger at civil court than PES. Quote OECD Unemployment Outlook 2004 in the Netherlands: "Civil courts usually dissolve the employment contract but require relatively high severance payments. [ . . ] On the other hand, no severance payment is required if the procedure is conducted by the PES [ . . . ." ( $p 70$, OECD, 2004)

In a next step, we fit a maximum likelihood probit model that explains whether the contract is dissolved or not. ${ }^{170}$

${ }^{170}$ We use only contradiction cases because in non-contradiction cases the judge does not decide about the outcome. 
$\operatorname{Pr}($ Contract not dissolved $=1)=\emptyset\left(\beta_{0}+\beta_{1} U N E M P L+\beta_{2} E C O N+\beta_{3} D U R+\beta_{4} D I S M P R+\beta_{5} R\right.$ $\left.+\beta_{6} S\right)$

where $\varnothing$ is the cumulative normal distribution. The independent variable is a dichotomous variable that indicates whether the contract is dissolved or not (REFUSED; 1=not dissolved, $0=$ dissolved) UNEMPL is the adjusted unemployment rate, and ECON stands for economic dismissals. DUR is the Duration of the civil court procedure . Furthermore, $\mathrm{R}$ is a set of employee specific variables, such as Tenure (TEN), Age (AGE), gender (MAN), Hourly wage (HOURW) and Working hours per week (WHOURS). Last, $S$ includes the employer specific characteristics Industry (INDUS), Legal form (LIML, FOUND, OTHERL) and Size (LESS10, BT10-100, MORE100).

Table 3 Descriptive statistics, Hypothesis 1, PES data ( $n=823,2006-2009)$

\begin{tabular}{|c|c|c|c|c|c|c|}
\hline & $\begin{array}{l}\text { Unemploy- } \\
\text { ment rate } \\
\text { (UNEMPL) }\end{array}$ & $\begin{array}{c}\text { Duration } \\
\text { (DUR) }\end{array}$ & $\begin{array}{l}\text { Age } \\
\text { (AGE) }\end{array}$ & $\begin{array}{c}\text { Tenure in } \\
\text { months } \\
\text { (TEN) }\end{array}$ & $\begin{array}{l}\text { Hourly wage } \\
\text { (HOURW) }\end{array}$ & $\begin{array}{l}\text { Hours per week } \\
\text { (WHOURS) }\end{array}$ \\
\hline Mean & 4.76 & 1.50 & 45.25 & 123.81 & $€ 13.07$ & 30.72 \\
\hline Median & 4.96 & 1.25 & 46.00 & 87.75 & $€ 12.10$ & 36.00 \\
\hline Std. Dev. & 0.69 & 1.19 & 10.23 & 103.17 & $€ 5.10$ & 10.40 \\
\hline Minimum & 3.72 & 0.00 & 17.00 & 1.81 & $€ 3.59$ & 2.13 \\
\hline Maximum & 6.06 & 10.82 & 70.00 & 513.44 & 69.25 & 50.00 \\
\hline
\end{tabular}

Table 9 presents the probit analyses with marginal effects $(\partial \emptyset / \partial x)$ at the means of all continuous variables $(x=\bar{x}$.) For the dichotomous variables, $\partial \emptyset / \partial x$ is for a discrete change of the dichotomous variable from 0 to 1 . Model 1 presents the full model in which we have included all variables as reported in Table 6 . The variable that indicates whether dismissal is requested for economic reasons (ECON) is insignificant, the same holds true for the set of employee specific variables (R) and for the variables legal form (FOUND, OTHERL) and size (LESS10, BT10-100). The joint effect of the industry dummies (INDUS) is significant (Wald test statistic $=18.38, p=0.005$ ). In order to achieve a better model fit, we excluded ECON, TEN100, MAN, HOURSW, WHOURS, FOUND, OTHERL LESS10 and BT10-100, which resulted in model $2 .{ }^{171}$ As in Model 1, Model 2 shows an insignificant effect of the unemployment rate (UNEMPL) on the likelihood that the contract is not dissolved. This result forces us to reject hypothesis 2 . A remarkable result is seen for the effect of the industry in which an employer operates. Employees working in the transport, storage and communication sector have a $20 \%$ higher likelihood of not being dismissed than employees working in the industry sector. This percentage is quite substantial, which we are not able to explain with certainty. A possible explanation is that, in comparison to other sectors the industry sector was hit hard by the economic crisis in the period that our data covers. Employment figures in this sector have been decreasing over the last ten years (UWV, 2011).

\footnotetext{
${ }^{171}$ A likelihood ratio test is conducted that compares model 2 to model 1 . The LR $\chi^{2}$ equals 13.15 with corresponding p-value of 0.4364 .
} 


\subsection{Discussion}

Following our earlier assumption that a judge's decision is independent of the unemployment rate, the rejection of hypothesis 2 implies that the quality of cases that is submitted at the civil court is of constant quality. As such, our results provide evidence that the weaker recession induced cases are filed at the PES.

A limitation of this study is that we do not have access to a variable that measures the severity of a case. Hence, we cannot conclude with 100 percent certainty that the assumption we made in which we state that the way in which dismissals are evaluated are independent of the state of the economy applies for the civil court. For the PES this assumption seems very much valid, mainly because of the detailed checklist in the Dismissal Decree that stipulates all conditions that a fair dismissal must fulfill.

In order to better understand the reason behind the rejection of hypothesis 2 we looked for a different explanation of this rejection. As mentioned earlier, the civil court may verdict the employer to award the employee a severance payment. If high unemployment rates indeed induce the admission of lower quality cases, this is possibly reflected in the height of the severance payment. Instead of not dissolving the employment contract, the court might decide to award a relatively higher damage award to the concerned employee. We conducted several analyses to verify this idea. Significant proof, however, was not found. Another possible explanation for the rejection of hypothesis 2 is that civil court courts are more likely to decide in favor of employers when the economy is down. Further research is needed to shed light on this issue. Not only because it is important for policy makers to understand the dynamics behind the evaluation of dismissal disputes, but also because from a normative point of view, the law should not be dependent of the appointing authority, or of the situation in which these laws are enforced. We know from research conducted in different settings than the labor market that judicial independence is not always the norm. Besley and Case (1995) provide evidence that gubernatorial term limits significantly affect economic policy choices. Similar results are found by Huber and Gordon (2004) who predict that judges that face elections have a tendency to become more punitive. Related, Elling (1982), Thomas (1985) and Wright and Berkman (1986) predict that more liberal officials become more conservative when approaching elections. Hall (1992) shows that decisions made by state supreme court justices are strategic decisions to minimize electoral opposition. In labor economics, Ichino et al. (2003) show that in regions in Italy with higher unemployment judges are less likely to decide in favor of the firm. Using the 1992 survey of Employment Tribunal Applications in Great Britain, Marinescu (2011) finds an opposite result. She shows that both the bankruptcy rates and the unemployment rate significantly decrease the likelihood that a judge decides in favor of the dismissed employee. Although the Dutch labor market and policy rules are very different from the Italian and the British, we should not rule out the possibility that Dutch courts are also influenced by the state of the economy. As mentioned earlier, further research is needed. 


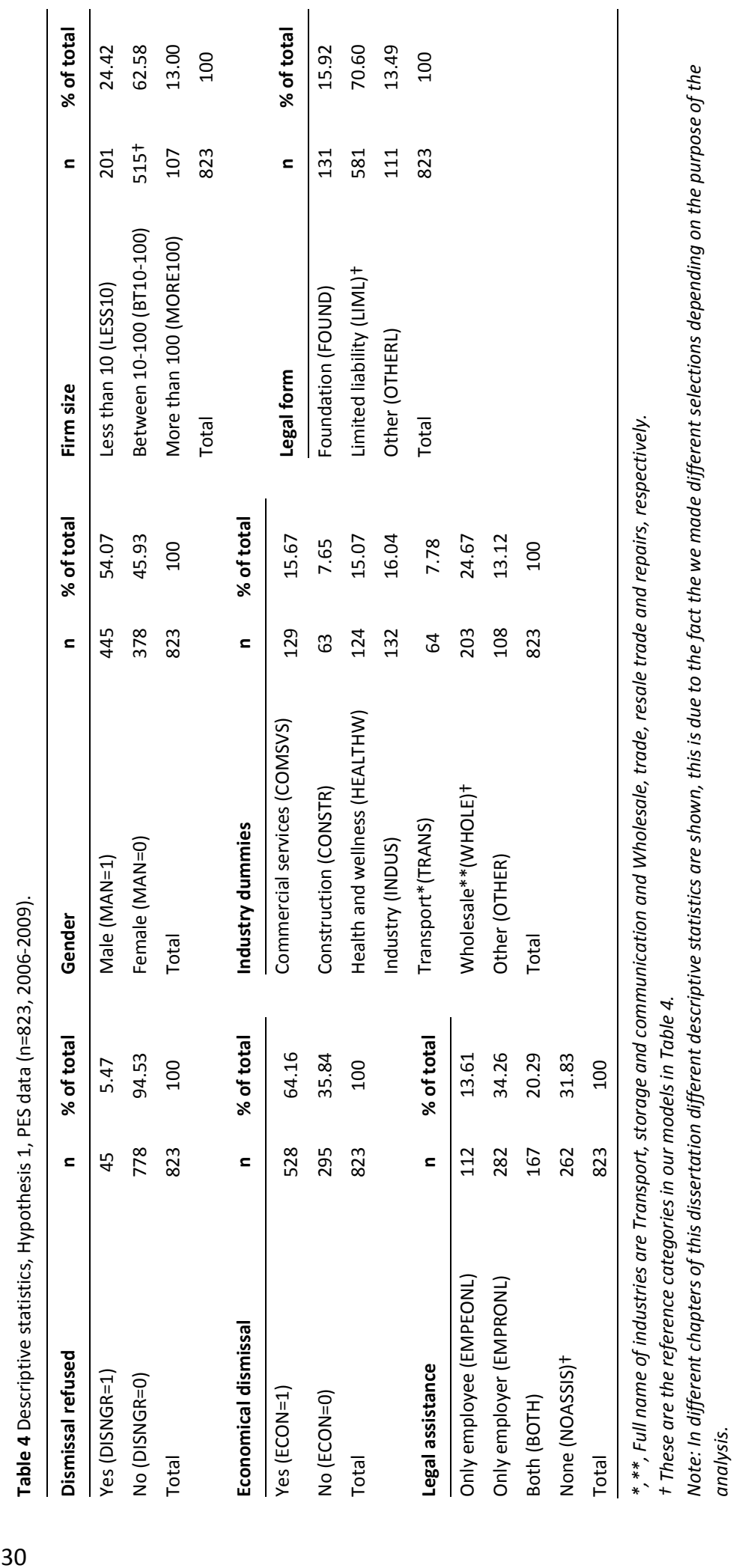


Table 5 Probit marginal effects "at the means", Hypothesis 1, PES data ( $n=823,2006-2009)$.

\begin{tabular}{|c|c|c|c|c|c|c|c|}
\hline DV: Dismissal refused & & Model 1 & & & Model 2 & & X-bar \\
\hline Variables & $d y / d x$ & St. Err. & p-value & $d y / d x$ & St. Err. & p-value & \\
\hline UNEMPL & 0.018 & 0.009 & 0.041 & 0.020 & 0.010 & 0.040 & 4.76 \\
\hline ECON & -0.018 & 0.016 & 0.263 & -0.032 & 0.017 & 0.060 & 0.64 \\
\hline DUR & 0.008 & 0.004 & 0.049 & 0.010 & 0.005 & 0.028 & 1.50 \\
\hline EMPRONL* & -0.018 & 0.017 & 0.289 & -0.020 & 0.017 & 0.242 & 0.34 \\
\hline EMPEONL* & 0.089 & 0.039 & 0.023 & 0.091 & 0.039 & 0.021 & 0.14 \\
\hline ВОTH* & 0.030 & 0.026 & 0.247 & 0.038 & 0.027 & 0.155 & 0.20 \\
\hline AGE100 & -0.020 & 0.062 & 0.742 & & & & 0.46 \\
\hline TEN100 & -0.003 & 0.006 & 0.675 & & & & 1.24 \\
\hline MAN & 0.007 & 0.016 & 0.662 & & & & 0.54 \\
\hline HOURW & 0.001 & 0.001 & 0.602 & & & & 13.07 \\
\hline WHOURS & 0.001 & 0.001 & 0.214 & & & & 30.72 \\
\hline FOUND** & 0.064 & 0.059 & 0.282 & & & & 0.16 \\
\hline OTHERL** & -0.030 & 0.013 & 0.016 & & & & 0.14 \\
\hline LESS10*** & 0.009 & 0.018 & 0.604 & & & & 0.24 \\
\hline MORE100*** & 0.017 & 0.028 & 0.556 & & & & 0.13 \\
\hline Industry Dummies & Yes & & & No & & & \\
\hline Quarterly & Yes & & & No & & & \\
\hline Log likelihood & -148.979 & & & -155.215 & & & \\
\hline $\mathrm{N}$ & 823 & & & 823 & & & \\
\hline $\begin{array}{l}\text { LR X2 (model } 1 \text { versus } \\
\text { model } 2)^{\dagger}\end{array}$ & 12.47 & & & & & & \\
\hline Sig. & 0.82 & & & & & & \\
\hline
\end{tabular}

Note 1: We have also run a linear probability model (LPM). The results are very similar: Model 1 in LPM form: coefficient for UNEMPL:0.025, sig. $=0.035$. Model 2: coefficient for UNEMPL: 0.024, sig. $=0.032$.

Note 2: The Wald test that tests for the joint significance of the legal assistance dummies (EMPRONLY, EMPEONLY, BOTH) gives the following result: Model 1: $\chi^{2}=18.45$, sig=0.00, Model 2: $\chi_{2}=19.36$, sig $=0.00$,

Note 3: As a robustness check we conducted the same analysis with the complete ARCOS PES data for the region Maastricht. We used another measure of the state of the economy, namely the vacancy rate. The vacancy rate is defined as the number of vacancies per one thousand jobs. We found that increasing vacancy rates are associated with an increase in the likelihood that permission is granted. These results are similar to the results we present in this chapter.

Note 4: Unemployment rates are given for each month in which the case is closed.

***,***; reference categories are: NOASSIS, LIML, BT10-100, respectively.

tThe additional variables in Model 1 do not result in a statistically significant improvement of our model fit. 
Table 6 Description of variables Hypotheses 2, civil court data.

\begin{tabular}{|c|c|c|}
\hline Variables & Abbreviation & Description \\
\hline \multicolumn{3}{|l|}{ Dependent variables } \\
\hline Contract not dissolved $(\mathrm{H} 2)$ & REFUSED & $\begin{array}{l}\text { This variable is the dependent variable in hypothesis } 2 \text {. It has the value } \\
1 \text { if the court has not dissolved the employment contract and } 0 \\
\text { otherwise. }\end{array}$ \\
\hline \multicolumn{3}{|l|}{ Continuous variables } \\
\hline Unemployment rate & UNEMPL & $\begin{array}{l}\text { The monthly unemployment rate for the total Netherlands is adjusted } \\
\text { for seasonality and calculated by dividing the total unemployed } \\
\text { working population in the Netherlands by the total working population } \\
\text { in the Netherlands. }\end{array}$ \\
\hline $\begin{array}{l}\text { Duration procedure in } \\
\text { months }\end{array}$ & DUR & $\begin{array}{l}\text { Duration of the civil court procedure, time in between registration } \\
\text { date and the date of the court decision }\end{array}$ \\
\hline Age & AGE100 & Age in years divided by 100 . \\
\hline Tenure in months & TEN100 & Tenure in months divided by 100 . \\
\hline Hourly wage & HOURW & $\begin{array}{l}\text { Hourly wage of the employee, excluding holiday pay and additional } \\
\text { fees. }\end{array}$ \\
\hline Working hours per week & WHOURS & Number of working hours per week of the concerned employee \\
\hline Severance payment & SEVP & $\begin{array}{l}\text { Indicates the amount of severance payment awarded to the employee } \\
\text { - only available for the civil court. }\end{array}$ \\
\hline \multicolumn{3}{|l|}{ Categorical variables } \\
\hline Economical dismissal & ECON & $\begin{array}{l}\text { Reason for dismissal as indicated by the employer. ECON stands for } \\
\text { economical dismissals }\end{array}$ \\
\hline Non economical dismissal & NONECON & $\begin{array}{l}\text { Reason for dismissal as indicated by the employer. NONECON stands } \\
\text { for non-economic dismissals }\end{array}$ \\
\hline New civil court formula & NEWCC & $\begin{array}{l}\text { This variable indicates whether the new or the old Civil Court formula } \\
\text { holds. The new formula is introduced Jan 1st } 2009 \text { (dichotomous). It is } \\
\text { used for testing hypothesis } 3 \text { and } 4 \text {. }\end{array}$ \\
\hline Industry & INDUS & $\begin{array}{l}\text { The industry in which the employer operates (dichotomous variables } \\
\text { for the different industries. }\end{array}$ \\
\hline Less than 10 employees & LESS10 & Size of firm (dichotomous) \\
\hline $\begin{array}{l}\text { Between } 10 \text { and } 100 \\
\text { employees }\end{array}$ & BT10-100 & Size of firm (dichotomous) \\
\hline More than 100 employees & MORE100 & Size of firm (dichotomous) \\
\hline Gender & MAN & $\begin{array}{l}\text { This variable indicates whether the employee is male or female } \\
\text { (dichotomous) }\end{array}$ \\
\hline Limited liability & LIML & Legal form the employer holds (dichotomous) \\
\hline Foundation & FOUND & Legal form the employer holds (dichotomous) \\
\hline Other & OTHERL & Legal form the employer holds (dichotomous) \\
\hline
\end{tabular}


Table 7 Descriptive statistics, Hypothesis 2, Civil court data ( $n=404,2003-2009)$.

\begin{tabular}{lcccccc}
\hline & $\begin{array}{c}\text { Unemployment } \\
\text { rate (UNEMPL) }\end{array}$ & $\begin{array}{c}\text { Duration } \\
\text { (DUR) }\end{array}$ & $\begin{array}{c}\text { Age } \\
\text { (AGE) }\end{array}$ & $\begin{array}{c}\text { Tenure in } \\
\text { months } \\
\text { (TEN) }\end{array}$ & $\begin{array}{c}\text { Hourly wage } \\
\text { (HOURW) }\end{array}$ & $\begin{array}{c}\text { Hours per week } \\
\text { (WHOURS) }\end{array}$ \\
\hline Mean & 5.67 & 1.00 & 42.75 & 135.92 & $€ 16.26$ & 33.41 \\
Median & 5.90 & 0.92 & 43.00 & 73.00 & $€ 14.07$ & 36.46 \\
Std. Dev. & 0.83 & 0.84 & 10.78 & 137.52 & $€ 8.70$ & 7.99 \\
Minimum & 3.72 & 0.00 & 21.00 & 2.10 & $€ 6.53$ & 4.85 \\
Maximum & 6.67 & 9.47 & 63.00 & 536.25 & $€ 81.64$ & 44.61 \\
\hline
\end{tabular}

The idea that employers use economic slumps as an excuse to fire employees is related to the idea of moral hazard. The concept of moral hazard implies that people have the tendency to take risk because the costs that could incur are not felt by that person. They ignore the moral implications of their choice and will do what benefits them the most. In this specific situation, moral hazard emerges due to the fact that the employer does not take the full consequences of its firing decisions. As such, he has a tendency to dismiss a worker on unjustifiable grounds and let the Dutch taxpayer pick up the check of additional unemployment. Herewith, the employer leaves the Dutch society responsible for the consequence of his actions. Because risks at stake are larger during economic slumps, the risk of moral hazard increases in recessionary times. In times of economic upturn the need to layoff personnel without a reasonable cause is less persistent. Our analysis suggests that the lower quality recession induced cases are less likely to be granted by the PES. In other words, when the employer is not able to convince the PES that the dismissal is based on reasonable grounds, permission is not given. As such, the consequences of a firm's moral hazard are reduced. These results are desirable because they indicate that an employer cannot just fire an employee without a reasonable cause. Without a check of the reasonableness of the dismissal and without the PES to put a halt to unfair recession induced dismissals, times of economic slumps will elicit an increase in the number of employees that are fired unfairly. The absence of a preventative check is a reality for all other OECD countries. In such a system, costs of moral hazard are higher. 


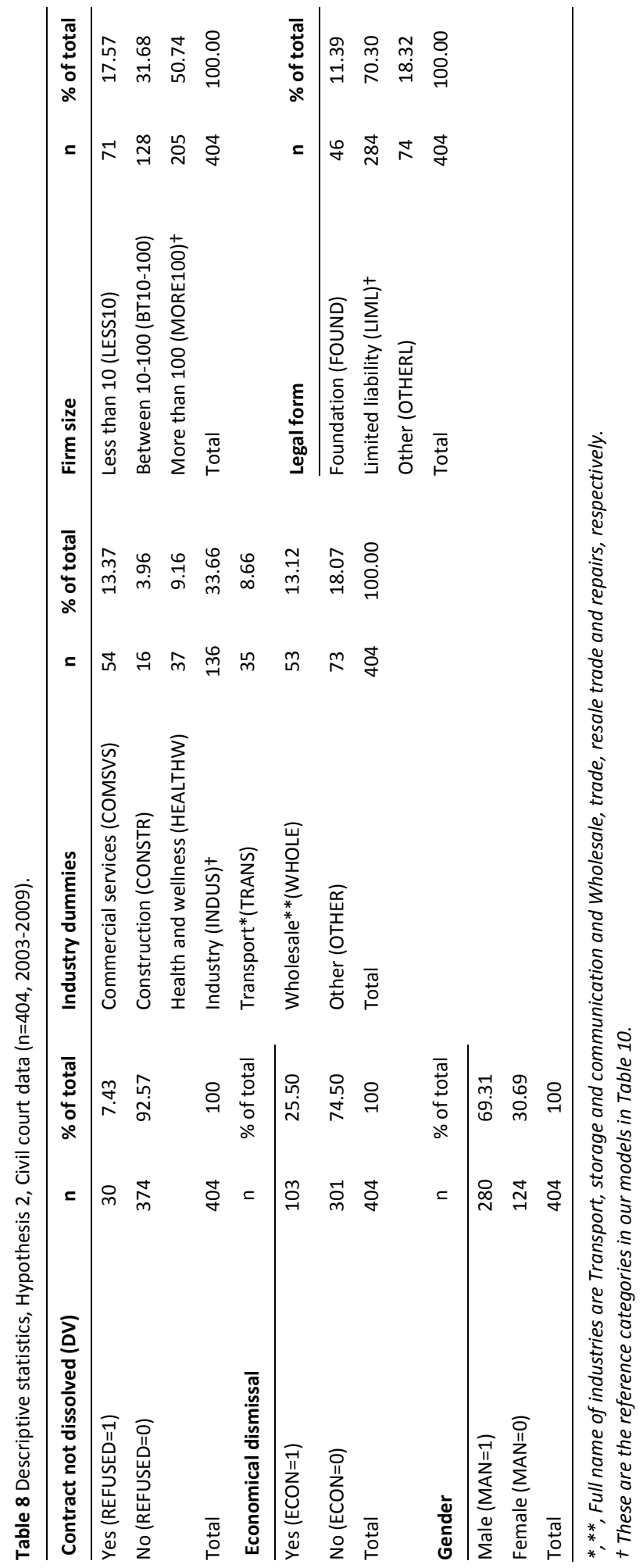


Table 9 Probit marginal effects "at the means", Hypothesis 2, Civil court data ( $n=404,2003-2009$ ).

\begin{tabular}{|c|c|c|c|c|c|c|c|}
\hline \multirow{2}{*}{$\begin{array}{l}\text { DV: Dismissal } \\
\text { refused } \\
\text { (REFUSED) } \\
\text { Variables }\end{array}$} & \multicolumn{3}{|c|}{ Model 1} & \multicolumn{3}{|c|}{ Model 2} & \multirow[t]{2}{*}{ X-bar } \\
\hline & $d y / d x$ & St. Err. & p-value. & $d y / d x$ & St. Err. & p-value. & \\
\hline UNEMPL & 0.003 & 0.012 & 0.811 & 0.000 & 0.014 & 0.977 & 5.67 \\
\hline ECON & 0.002 & 0.022 & 0.912 & & & & 0.25 \\
\hline DUR & 0.017 & 0.010 & 0.077 & 0.023 & 0.011 & 0.035 & 1.00 \\
\hline AGE100 & 0.180 & 0.117 & 0.122 & & & & 0.43 \\
\hline TEN100 & -0.009 & 0.010 & 0.368 & & & & 1.36 \\
\hline MAN & 0.026 & 0.026 & 0.320 & & & & 0.69 \\
\hline HOURW & 0.000 & 0.001 & 0.840 & & & & 16.26 \\
\hline WHOURS & 0.002 & 0.002 & 0.282 & & & & 33.41 \\
\hline FOUND* & -0.018 & 0.032 & 0.583 & & & & 0.11 \\
\hline OTHERL* & -0.026 & 0.022 & 0.242 & & & & 0.13 \\
\hline LESS10** & -0.037 & 0.022 & 0.092 & & & & 0.18 \\
\hline ВТ10-100** & 0.011 & 0.024 & 0.631 & & & & 0.32 \\
\hline \multicolumn{8}{|l|}{ Industry*** } \\
\hline COMSVS & -0.013 & 0.031 & 0.683 & -0.023 & 0.031 & 0.466 & 0.13 \\
\hline CONSTR & 0.033 & 0.068 & 0.629 & 0.066 & 0.087 & 0.444 & 0.04 \\
\hline HEALTHW & 0.109 & 0.120 & 0.364 & 0.018 & 0.047 & 0.698 & 0.09 \\
\hline TRANS & 0.198 & 0.095 & 0.037 & 0.221 & 0.087 & 0.011 & 0.09 \\
\hline WHOLE & -0.027 & 0.026 & 0.290 & -0.044 & 0.026 & 0.088 & 0.13 \\
\hline OTHER & 0.010 & 0.037 & 0.790 & -0.016 & 0.030 & 0.604 & 0.18 \\
\hline $\begin{array}{l}\text { Quarterly } \\
\text { Dummies }\end{array}$ & Yes & & & No & & & \\
\hline Log likelihood & -86.08 & & & -92.66 & & & \\
\hline $\mathrm{N}$ & 404 & & & 404 & & & \\
\hline $\begin{array}{l}\text { LR X2 (Model } 1 \\
\text { versus Model } \\
2)^{+}\end{array}$ & 13.15 & & & & & & \\
\hline Sig. & 0.44 & & & & & & \\
\hline
\end{tabular}

Note 1: We have also run a linear probability model (LPM). The results of the LPM are the following: Model 1 in LPM form: coefficient for UNEMPL: 0.004, sig. $=0.801$, Model 2 in LPM form: coefficient for UNEMPL:0.003, sig. $=0.843$.

Note 2: The Wald test that tests for the joint significance of the industry dummies gives the following result: Model 1: $\chi^{2}=18.38$, sig=0.01, Model 2: $\chi^{2}=22.79$, sig=0.009.

Note 3: Unemployment rates are given for each month in which the case is closed.

, ,**,***; reference categories are: LIML, MORE100, INDUS respectively.

the additional variables in Model 1 do not result in a statistically significant improvement of our model fit.

\subsection{Conclusion}

Dutch law regarding the termination of permanent employment contracts is unique in the world. Instead of applying a repressive check of dismissal as most countries do, the Netherlands 
applies a preventative check of dismissal. This preventative check entails that an employer, when intending to dismiss a permanent worker, can ask for dismissal permission at the public employment service (PES) or he can request the civil court to dissolve the employment contract. When unemployment rates increase the number of requests filed at both the PES and the civil court increase. This holds true for both economic and non-economic dismissals. As shown earlier by Ichino et al. (2003) and Siegelman and Donohue III (1995) recession induced cases are of lower quality when seen from the plaintiff's perspective. We theorized that these recession induced cases in the Netherland exhibit the same characteristic. If so, the likelihood that permission is granted or the contract is dissolved should decrease with increasing unemployment rates. This however, only holds true under the assumption that judicial decision making is independent of the state of the economy.

Under the above stated assumption that both routes act independently from the state of the economy, this paper provides evidence that recession induced cases filed the PES are of poorer quality. These additional cases are not granted permission by PES. In other words, the PES acts as a barrier that only allows reasonable dismissal requests to be enacted. Unreasonable requests are not honored. As such, the PES prevents that costs of unemployment due to unfair dismissal are imposed on Dutch society. For the civil court we do not find that recession induced cases have a larger likelihood of being rejected. This either implies that the assumption of judicial independence is a too strong assumption for the civil court to make or that recession induced lower quality cases only end up at PES and that cases filed the civil court are of constant quality over the business cycle. Further research has to shed light on this issue. Not only because it is important for micro economists and policy makers to understand the dynamics behind the evaluation of dismissal disputes, but also because the law should not be dependent of the appointing authority, or of the situation in which these laws are enforced.

We furthermore find that employer-specific and employee- specific characteristics do not influence the decision of the judge or the PES. From a normative point of view, these findings reflect a practicing of law that is desirable. Employers nor employees that possess certain characteristics are being discriminated or given preference to. The only aspect that is important for termination is the severity of the case.

From a macro perspective our research is important because it suggest that with higher unemployment rates firing decisions are made differently. Although this research is conducted in a Dutch setting it is not unlikely that these results are also applicable to other countries. 
CHAPTER 7:

POLICY IMPLICATIONS 


\subsection{Introduction}

We mentioned in previous chapters of this dissertation that the duality of the Dutch employment protection legislation $(E P L)^{172}$ has been under continuous attack. Over time different governments have tried to introduce a simpler, less rigid system. Central arguments used are that the Dutch EPL, with accompanying high firing costs, does not positively influence participation rates. Its procedures are overly complex and it does not ensure an optimal working of the labor market. It has made it difficult for employers to hire and fire employees and for outsiders, especially older people, to enter the labor market. ${ }^{173}$ Additionally, emphasis is put on inequalities in compensation and different treatment of similar cases due to the existence of two routes of dismissal. ${ }^{174}$ The system is characterized as inflexible.

One of the most recent attempts ${ }^{175}$ to modify the Dutch EPL is recorded in the Spring Agreement ${ }^{176}$ of May 2012, which was made by the Kunduz ${ }^{177}$ parties VVD, CDA, D66, GroenLinks and ChristenUnie. The central theme in the agreement with respect to EPL is the abolishment of the preventative check of dismissal. Before the general elections of September 2012, political parties have put strong emphasis on the revision of EPL. They have either crystalized the proposal in their election programs, or have decided to leave EPL untouched. ${ }^{178}$ The past repeats itself as political parties cannot come to an agreement. ${ }^{179}$

This chapter aims to provide an overview of our findings of previous chapters, to provide an outlook for future research and to give an overview of policy implications. In Section 2 of this chapter we present the Kunduz agreement in more detail. Section 3 sketches an overview of the reactions the agreement has provoked. We summarize a letter of protest that was sent by a delegation of scientist to the Upper Chamber on June 12th 2012. We furthermore present opinions from a workers', employers' and voters' perspective. In Section 4 we express our own point of view. We explain that the findings of this thesis are in line with the arguments made by the delegation of scientists in the letter of June $12^{\text {th }}$. We furthermore argue that the arguments in favor of a modification are not convincing. In Section 4 we put strength to this expression by showing that the new proposal does not lead to a decrease in average firing costs. Using a novel sample of 878 requests filed at the civil court and 994 request filed at the public employment service (PES) ${ }^{180}$ over the years 2006-2009 we show that the proposal results in an increase in

\footnotetext{
172 In this chapter, EPL is used as an acronym for Employment Protection Legislation.

${ }^{173}$ See the Request for Advice that was send to the Corporation of Labor about the modification of the Dutch dismissal system, (In Dutch: “Adviesaanvraag") of Minister Donner, dated July 32007 (AV/IR/2007/23064) and also the proposal of Koser Kaya, dated July 12011 ("Voorontwerp van een voorstel van wet tot wijziging van het ontslagrecht." D66, 2011).

${ }^{174}$ This argument is stressed mostly in Koser Kaya's proposal.

175 This chapter is written before the publication of the Coalition Agreement of political parties PvdA and CDA at October $29^{\text {th }}$ 2012. The Coalition Agreement does not follow the agreements made by the Kunduz parties. Therefore, we provide a small update in Chapter 8 of this dissertation.

${ }^{176}$ In Dutch: Lenteakkoord.

${ }^{177}$ Because of an earlier mutual agreement to support the police training missing in the Afghan province of Kunduz, the media started referring to these parties as the Kunduz parties. In this chapter we will also use this name.

${ }^{178}$ Parties that are against the abolishment of the preventative check are the SP, the PVV and the Socialistic Party. CDA, Democraten 66, GroenLinks, VVD are in favor of the abolishment of the preventative check. PvdA is in favor of a single preventative check via the civil court.

${ }^{179}$ In 2007 the political impasse about the modification almost lead to the fall of the government (See Chapter 2).

${ }^{180}$ In this chapter, PES is used as an acronym for public employment service.
} 
firing costs for employers that originally selected the PES route of dismissal, would they have been exposed to the proposed legislation. We furthermore show that firing costs for employers that originally selected the civil court route of dismissal will decrease. We conclude this chapter by presenting our point of view on what policymakers can learn from this dissertation and on how to proceed in the future.

\subsection{The Kunduz proposal}

In the Spring Agreement of May 2012 the Kunduz-parties VVD, CDA, D66, GroenLinks and ChristenUnie proposed a new drastic revision of the current Dutch EPL. This proposal was revised and sketched in more detail by Henk Kamp, (outgoing) Minister of Social Affairs and Welfare and was sent to the Upper Chamber at the 18 th of June $2012 .{ }^{181}$ The proposal contains three central elements:

1. The current preventative check by the PES and the civil court is replaced by a single repressive check by the court. This implies that an employer is allowed to dismiss an employee without an a priori permission. A reasonable ground for dismissal should exist. Furthermore, a hearing procedure is introduced during which the employee is allowed to react. If the employee does not agree with the dismissal, he may file a lawsuit against the employer in court. If the court judges the dismissal to be unreasonable, it may re-establish the employment contract or it may award a compensation that equals half a monthly salary per year of employment, with a maximum of 12 months. ${ }^{182}$

2. Severance payments are replaced by a transition budget that is used for schooling and other routes that stimulate a person's capability for gaining and maintaining employment. These budgets are set to maximum of six months and equal a quarter of a monthly salary per year of employment. All workers that are dismissed involuntarily, both workers with fixed and permanent contracts, are entitled to receive a budget.

3. Employers shall finance (at maximum) the first six months of the unemployment benefit of workers with a permanent contract and with a fixed contract. Part of the unemployment premium that is paid by employers is expected to be abolished. ${ }^{183}$ According to Minister Kamp, the technical details of this specific detail of this proposal will be further revised. ${ }^{184}$ The period of notice is furthermore revised. It is no longer dependent upon the years of service, but equals 2 months for all workers.

The proposed modification is supposed to lead to less inequality between workers with a fixed contract and workers with a permanent contract. It is moreover supposed to result in lower firing costs for older employees. As such, the cabinet argues that the offering of permanent

\footnotetext{
${ }^{181}$ It is titled in Dutch: "Hoofdlijnen aanpassing ontslagrecht en ww."

${ }^{182}$ The award is received on top of the severance budget that is received by the employee at dismissal.

${ }^{183}$ An employer pays a sector premium, which is dependent on the risk of unemployment in the sector in which the employer operates. This premium is expected to be abolished. The employer also pays a premium for the general unemployment fund (In Dutch: "Algemeen werkloosheidsfond" (WW-Awf)). This premium is not abolished.

${ }^{184}$ In the Spring Agreement (BZ/2012/283M) it is stated that employers will finance one month per year of employment with a minimum of three months for workers with a permanent contract. Counted are only the years of employment with the concerned employee. The proposal of Minister Kamp remains silent about this issue.
} 
contracts is stimulated and labor market mobility of the older generation is positively affected. Last, the financing of the first months of employment benefit by the employer will contribute to the recovery of the governmental fund (Voorjaarsnota, 2012, BZ/2012/283M).

\subsection{Reactions}

\section{The scientific arena}

In an official letter to the Upper Chamber and all political parties involved, dated June $12^{\text {th }} 2012$, a group of 16 scientists ${ }^{185}$ affiliated to several universities in the Netherlands expressed their concerns about the proposals made regarding the modification of the financing of unemployment benefits and the employment protection system. According to the delegation, the plans of the government are based on untested assumptions, and will instead of positively, negatively affect the Dutch economy and labor market. The delegation of scientist argues that the Dutch EPL is not as inflexible as the government wants us to believe. A wide range of possibilities exists to hire flexible workers and the difficulty to fire permanent workers is overstated. As the delegation argues, most requests filed at the civil court and the PES are honored. They furthermore reason that in terms of the average OECD EPL-index, the Netherlands is an average performer and that there is no scientific proof for the idea that a more flexible EPL results in more employment. No general rule exists that countries with high protection have poor functioning labor markets. Examples mentioned are Luxembourg and Germany. These countries both have strict EPL but outperform many other countries that have a less rigid system.

Another instrument used by the delegation to oppose to the new modification is the research of Dekker and Kleinknecht (2008), Vergeer and Kleinknegt (2010) and Kleinknecht, Naastepad en Storm (2012). These authors present the idea that a more flexible EPL will negatively affect productivity and innovation. They argue that because of a larger outflow of personnel due to a more flexible EPL, employers are less willing to invest in schooling. The same holds for employees, who will be less willing to invest in job-specific schooling.

The delegation of scientist is against the idea to let the employer finance the unemployment benefit in the first months of unemployment. Eventually, the scientists argue, in times of economic downturn this may drive employers into bankruptcy, with disastrous outcomes for employment and the Dutch economy. The delegation furthermore claims that the new proposed modification will lead to a worsened labor market position of 'outsiders'. These outsiders are often low skilled, older, or both, and will not be hired more easily, so claims the delegation. Instead, insiders within that specific group have a larger likelihood of being fired.

With respect with the proposal to put a halt to large severance payments, the delegation stresses the fact that the high bonuses that are often awarded are not based on the Civil Court Formula, but are the result of mutual agreements made by the employer and the employee. The proposal to maximize the severance payment will not put a halt to these practices. The scientists

\footnotetext{
${ }^{185}$ These are: Prof. mr. dr. W.H.A.C.M. Bouwens, Prof. mr. dr. C.J. Loonstra, Prof. mr. dr. W.A. Zondag, Prof. mr. dr. F.J.L. Pennings, Prof. mr. dr. M.S. Houwerzijl, Prof. dr. K. Boonstra, Prof. mr. dr. A.R. Houweling Prof. mr. dr. E. Lutjens, Prof. mr. dr. A.P.C.M. Jaspers, Mr. dr. W.L. Roozendaal, Mr. dr. L. van den Berg, Mr. dr. S.F.H. Jellinghaus, Dr. R. Dekker, Mr. S.H. Kuiper Mr. I.R.W. Witte Mr. D.M.A. Bij de Vaate.
} 
write in their letter that the differences in severance payments will only get larger as lower segment workers are not able to negotiate a large severance package and are forced to accept a less attractive legal maximum.

The delegation furthermore reasons that the introduction of a pure repressive system is beneficial for neither employers nor employees. Enforcement of the proposal will lead to a deteriorated legal position of employees as they are the ones that have to initiate the reasonableness check of the dismissal. For some, this is a high barrier to cross. For employers, moreover, a repressive system implies insecurity. Long after the dismissal has taken place, they may be confronted with the costs that result from a repressive procedure. In their letter, the delegation of scientists stresses that they do not oppose against a modification of the Dutch dismissal system per se. They plead for a repressive check of which the criteria are stipulated in a collective labor agreement. This check is supposed to be executed by a dismissal committee composed by employers, employers' organizations and labor unions. If such an agreement does not exist, the PES should judge whether dismissal is based on reasonable grounds. ${ }^{186}$ The delegation furthermore stresses that the differences in dismissal awards are unjustifiable.

In the NRC Handelsblad of May 29, 2012, Boontje, Sick and Loonstra ${ }^{187,188}$ present a similar view as the delegation. They argue that the new proposed system is expensive and will lead to more bureaucracy and inequality. A repressive procedure will lead to additional (costly) lawsuits and insecurity. They furthermore sketch the possibility that the preventative hearing procedure will evolve in a PES-like procedure, but instead privatized.

Bartelsman, Gautier and De Wind (2012), express their disagreement with the arguments made by the delegation of scientists. First of all, Bartelsman et al. (2012). disagree with the statement that the Dutch EPL is not inflexible. As a counterargument they present the index for EPL for permanent workers, on the basis of which the Netherlands is marked with one of the strictest EPL of all OECD-countries. They furthermore argue that although the Netherlands performs relatively well in terms of unemployment, the burden of unemployment is carried by a small group of long term unemployed. Second, Bartelsman et al. (2012) are in the opinion that no proof exists that the group of outsiders, as defined by the delegation, that will be fired due to a more flexible EPL is large. They furthermore argue that it is misleading to present Germany as an example with very rigid EPL and not to mention Portugal, a country that has more rigid EPL. Third, Bartelsman et al. refer to their own research to oppose against the argument that a flexible EPL leads to lower productivity (Bartelsman, Gautier and De Wind, 2010, 2011). Herein, the authors illustrate that countries that have rigid employment protection are relatively unproductive and risk averse in investing in new technology.

\footnotetext{
${ }^{186}$ The delegation of scientists do not describe their proposal in great detail. They for instance, do not describe the position of the civil court in a new employment protection system.

187 Paul Boontje and Pauline Sick are affiliated to Boontje Advocaten in Amsterdam. Cees Loonstra is Professor Employment Law at Erasmus University Rotterdam.

${ }^{188}$ Boontje, P., Sick, P., and Loonstra, C. "Wijziging ontslagrecht leidt tot veel juridische procedures" NRC Handelsblad, May 292012.
} 


\section{Workers, employers and voters}

Worker unions do not agree with the Kunduz proposal. On its website ${ }^{189}$, FNV Bondgenoten encourages the Dutch people to vote against the proposed modifications made. CNV is also against a modification and stresses that the focus of a revised EPL should be on the transition of one job to another. ${ }^{190}$

Employers are generally in favor of a simplification. A survey performed by EenVandaag indicates that $84 \%$ percent of the employers approves of the simplification and $77 \%$ believes to profit from the proposed modification. Only $13 \%$ is against. ${ }^{191}$ Amongst employers' unions the simplification is received with moderate enthusiasm. VNO NCW-chairman Bernard Wientjes is generally known to be in favor of a more flexible $\mathrm{EPL}^{192}$, but expressed to understand that the proposed modification is a sensitive topic for worker unions. He expressed to take this into account during the formation of the new government, when composing the Fall Agreement. ${ }^{193,194}$ Employers union MKB Nederland is also in favor of a modification, but is not enthusiastic about the content of the Kunduz proposal. According to Biesheuvel, chairman of MKB Nederland, the current repressive check of the PES is functioning properly. He does not expect that the proposed modification will positively affect the hiring of new personnel. To achieve that, he argues, an employer should be relieved from the obligation to continue wage payment during the first two years of sickness of an employee. ${ }^{195}$

A survey performed by TNS NIPO shows that the majority of the Dutch voters does not approve of the new proposed modifications. Two third of the respondents is against. Only amongst VVD voters a slight majority of 51 percent supports the new plans. ${ }^{196}$ Apparently, the government failed in persuading the Dutch people that an EPL reform is a necessary condition for the economic recovery of the Netherlands.

Today, it remains uncertain if the proposed modification is enforced. After the general elections of September 2012 a new government will decide if, and in what form a new system will replace the old one (See Chapter 8 for an update that is written after the general elections of September 2012).

\footnotetext{
${ }^{189}$ www.fnvbondgenoten.nl/mijnbranche/branches/bakkersbedrijf/artikelen/517856-ontslagrecht_versoepeld/, retrieved September $10^{\text {th }} 2012$.

${ }^{190}$ www.cnv.nl/blog/blog-category/ontslag, retrieved September $10^{\text {th }} 2012$. See also the interview with Jaap Smit on nu.nl of August $22^{\text {nd }} 2012$, www.nu.nl/economie/2889937/cnv-voorzitter-pislink-als-werknemers-vogelvrij.html, retrieved September $15^{\text {th }} 2012$.

191 “Werkgevers: versoepeling ontslagrecht helpt." August 17, 2012, http://opinie.eenvandaag.nl/uitslagen/41094/werkgevers_versoepeling_ontslagrecht_helpt, retrieved September $15^{\text {th }} 2012$.

192 See for instance "Geen akkoord over ontslagrecht op Participatietop" Volkskrant June $26^{\text {th }}, 2007$ www.volkskrant.nl/vk/nl/2686/Binnenland/article/detail/850534/2007/06/27/Geen-akkoord-over-ontslagrecht-opParticipatietop.dhtml, retrieved September 15th 2012.

193 In Dutch: "Najaarsakkoord".

${ }^{194}$ In "Draagvlak voor ontslagversoepeling brokkelt snel af." Het Financieele Dagblad August 23, 2012. http://fd.nl/economie-politiek/228333-1208/draagvlak-voor-ontslagversoepeling-brokkelt-snel-af, retrieved September 15th 2012.

195 “MKB: Timing soepeler ontslagrecht slecht." Trouw July 3, 2012.

www.trouw.nl/tr/nl/4504/Economie/article/detail/3281018/2012/07/03/MKB-timing-soepeler-ontslagrechtslecht.dhtml, retrieved September 15th 2012.

196 TNS NIPO by order of Het Financiële Dagblad, in "Draagvlak voor ontslagversoepeling brokkelt snel af." Het Financiële Dagblad (www.fd.nl), August 23, 2012.
} 


\subsection{Our point of view}

Points of view against or in favor of a more flexible EPL are based on expectations. Employers expect that a more flexible employment protection system will facilitate hiring, employees are afraid to be fired without a cause. A more flexible EPL is supposed lead to a decrease in firing costs, those that benefit from the proposed modification are in favor, those that are harmed are against. Arguments used to defend a certain statement can always be found. An example is presented above; the delegation of scientists is against the proposed modification and uses the research of Kleinknecht as a proof to show that a more flexible EPL leads to lower labor productivity. Bartelsman, Gautier and De Wind (2012) express their disagreement with the delegation and use their own research that shows that a more flexible EPL leads to higher productivity. Differences in outcomes of these authors, and of any scientific research in general, are due to the fact that used samples, methodologies, and measures of flexibility are different. Dekker and Kleinknecht (2008) use a sample of Dutch companies. ${ }^{197}$ Flexibility is defined as the percentage of persons with a flexible contract. ${ }^{198}$ Bartelsman, Gautier and De Wind (2010) use a dataset covering industries in the Market Sector ${ }^{199}$ in the EU and the US. Flexibility is measured using firing cost indicators of the OECD and of the World Bank. One may argue about the applicability of both studies to the Dutch situation. The measure of EPL used by Dekker and Kleinknecht does not cover the complete range of employment protection laws in the Netherlands. The studies of Vergeer and Kleinknecht (2010) and Bartelsman et al. (2010) compare countries on the basis of an EPL indicator, which has its drawbacks because one may fail to take into account country specific information that may influence the results.

We agree to a great extent with the arguments against the Kunduz proposal that in are written in the letter sent by the delegation of scientists to the Upper Chamber and all political parties involved, on June 12th 2012. First of all, we agree that the proposed modification is a result of untested premises. The research of Kleinknecht that is used to support this argument, however, is easy to contradict (See Bartelsman et al. (2010), but also Autor, Kerr and Kugler (2007)). ${ }^{200}$ We showed that research on the effect of EPL on different labor market outcomes is ambiguous as different authors present different outcomes. This argument is difficult to dispute. Although it does not allow us to make predictions about the effect of EPL, for policymakers this implies that conclusions that have important implications for the Dutch situation should be drawn with great care.

Second, we agree with the statement that the Dutch EPL is not as rigid as the government claims it to be as over $90 \%$ of all requests is honored (See Chapter 5 and Chapter 6 of this dissertation). It is not impossible for employers to dismiss their employees as long as they provide the court or the PES with proof that dismissal is reasonable. The two routes together

\footnotetext{
${ }^{197}$ The authors used the OSA panel.

198 The authors distinguish between a measure of external flexibility and internal flexibility. External flexibility is defined as the percentage of persons with a flexible contract. Internal flexibility is defined as the percentage of persons that switched department or job within the company in the last year. Using OLS, the authors found that external flexibility has a negative effect on productivity. Internal flexibility on the other hand has positive effect.

199 The market sector includes industries in manufacturing, trade, finance and business services, but excludes agriculture, government and services. Utilities and nuclear fuel production are moreover excluded.

${ }^{200}$ Using the same argument, one may also contest against the argument made by Bartelsman et al. and refer to studies that find a positive effect.
} 
add to the flexibility of the system. Before deciding what route to follow, employers make a strategic choice by taking into account the likelihood of success and the costs. Most employers decide correctly, seen by the large number of requests that is honored. By definition, an EPL system without any check of dismissal (preventative or repressive) is more flexible. In such a system, firing costs are low and judicial procedures do not exist. An employee may be dismissed at will. Such a system however, provokes situations in which an employer dismisses at will. A worker may be dismissed because of differences in beliefs or preferences. In the current system, these cases are not filed at PES or civil court because of a high likelihood of being rejected. ${ }^{201}$

Third, with respect to the statement made that the Netherlands is just an average performer, the delegation of scientists presents a different angle than we do. The scientists present the average OECD-index. In Chapter 5 of this dissertation we focus on the permanent component of the EPL-index and conclude that although the Netherlands scores relatively high on the index, they outperform many other EU15 countries. The conclusion, however, that may be drawn from these two different points of view is a similar one, namely that the Netherlands does not perform badly at all.

The delegation of scientists also stresses that in some cases severance payments that are awarded are not based on the civil court formula, but are the result of mutual agreements made between employer and employee. We may carefully support this argument with our data. Out of 878 requests granted at the civil court in the period 2006-2009, eight requests involved severance payments that were between 3 and 4 times larger than a neutral severance payment. ${ }^{202}$ Six requests involved severance payments that were between 4 and 6 times larger than a neutral severance payment. Moreover, five requests involved severance payments that were over 6 times larger than a neutral severance payment. ${ }^{203,204}$ These higher severance payments are mostly awarded to dismissed workers with relatively short tenure and in proforma cases. ${ }^{205}$

Furthermore, we agree with the delegation that a pure repressive system is not beneficial for neither employers nor employees. First of all, a repressive system is not per definition more flexible. It might be easier to dismiss a worker, but without a preventative check of dismissal it is likely that a worker fights back in court. Using data of a large Italian bank in Italy -Italy only applies a repressive check of dismissal- Ichino et al. (2003) show that 86 out of 409 workers (this is $21 \%$ !) file a case in court because of unfair dismissal after being dismissed by their employer. In 17 cases, which is $17 \%$ of total, the court overrules the firing decision. The current preventative system in the Netherlands encourages employers to carefully motivate the dismissal intention, without such a preventative check it is not unlikely that the Netherland will

\footnotetext{
${ }^{201}$ We assume that if these cases would make it to PES or to court, rejection rates would be much higher.

202 By this we mean a severance payment with a $C$-factor of 1.

${ }^{203}$ The civil court formula is the following: $\mathrm{A} \times \mathrm{B} \times \mathrm{C}$, where $\mathrm{A}$ is the weighted years of service, $\mathrm{B}$ is the gross monthly wage including additional benefits and $C$ is the correction factor, which is usually set between 0 and 2 . The civil court data collected does not contain the actual correction factor (factor C). We do observe factor A, factor B and the severance pay that is awarded. These numbers allow us to estimate factor $\mathrm{C}$.

${ }^{204}$ We may have overstated this number because of the fact that our wage variable only includes the actual gross wage plus an $8 \%$ holiday payment, the wage variable does not include additional benefits.

${ }^{205}$ The average tenure of workers in the 19 above mentioned cases is 1.4 years, the maximum tenure is 3.5 years and the minimum tenure is .09 years.
} 
witness a similar situation as in Italy. In a letter to Koşer Kaya ${ }^{206}$, in connection with the earlier 2011 proposal to introduce a single repressive system, the Dutch Judicial Council ${ }^{207}$ pointed out that it expects that civil courts in the Netherlands will witness an increase in the number of employment law cases of over 15,000. Estimated additional costs equal $€ 25$ million. ${ }^{208}$ This is not taken into account in the proposal.

We moreover argue that the existence of the preventative check by the PES and the fact that employers are relieved from severance payments when following the PES route of dismissal have resulted in a unique system that reduces the costs of moral hazard that are imposed upon the Dutch society. The concept of moral hazard in this specific situation implies that employers will take the risk to unlawfully fire their employees if they have a reason to do so and ignore the moral implications of their choices. In times of economic downturn employers have an incentive to unlawfully fire an employee, without following the legal route (see Chapter 6), in order to prevent severance payment. The PES offers employers that are truly in economic distress the option to dismiss the employee without the obligation of severance payment. This makes the Dutch system unique and cost-effective since unemployment contributions may exceed the costs of the government relieving firms from severance payment (see Chapter 5).

\subsection{Some cost calculations: the current system versus the newly proposed system}

What if all employees in our sample of 994 PES dismissals and 878 civil court dismissals are fired under the new rules? ${ }^{209}$ Table 1 below shows the theoretical differences in costs of the current and of the new proposed system.

\footnotetext{
${ }^{206}$ Koser Kaya is a member of the political party Democrats 66, who proposed a similar modification of employment law in 2011.

${ }^{207}$ In Dutch: "Raad voor de Rechtspraak".

208 See the letter titled: "Advies Voorstel van wet van het lid Koşer Kaya tot wijziging van het Buitengewoon Besluit Arbeidsverhoudingen 1945, het Burgerlijk Wetboek en enkele andere wetten ter verbetering van de rechtsbescherming bij ontslag" that was sent by the council to Koşer Kaya at December 22nd, 2011.

${ }^{209}$ Herewith, we realize that different firing costs may result in a different selection of employees to be dismissed. As such, we do not claim that a similar selection of employees is dismissed in the new proposed system. For example, our calculations show that employers that selected the PES route are confronted with dismissal costs that are twice as high when using the proposed firing rules. These employers may depart from dismissing certain employees for which firing costs increase in the new system. Our purpose in this chapter is only to show how the new rules may be applied, ceteris paribus.
} 
Table 1 Costs of the current system and of the new proposed system. ${ }^{210}$

\begin{tabular}{lll}
\hline & Current EPL system & New proposed EPL system \\
\hline Severance payment & $\begin{array}{ll}\text { Civil court: According to the civil court } \\
\text { formula }(A \times B \times C) \text { PES: Severance pay is }\end{array}$ & $\begin{array}{l}\text { All: Budgets instead of severance payments. } \\
\text { not awarded }\end{array}$ \\
& $\begin{array}{l}\text { months and equal a quarter of a monthly salary } \\
\text { per year of employment. Both permanent and } \\
\end{array}$ & $\begin{array}{l}\text { flexible workers are entitled to receive the } \\
\text { budget. }\end{array}$
\end{tabular}

Period of notice (PoN) Civil court: None, the date of termination of the contract is determined by court. Ongoing wage costs are incurred during this period. PES: 1 to 3 months, dependent on years of employment with the concerned employer. Ongoing wage costs during the PoN are incurred. Ongoing wage cost are also incurred during the time in between date at which the case is closed and the date at which the PoN commences (see Chapter 4).

Costs of preventative procedure

Costs of repressive procedure

Costs of unemployment benefit
Civil court: Ongoing wage costs are incurred during the duration of the procedure.

PES: Ongoing wage costs are incurred during the duration of the procedure

Repressive procedures are not often followed in the current system ${ }^{\dagger}$.
All: 2 months for all dismissed workers. Ongoing wage costs are incurred during the PoN.
All: The preventative check is abolished. A hearing procedure is introduced. The exact details of the hearing procedure are not stipulated; as such we are not able to draw conclusions about the costs that are incurred due to this procedure.

Repressive procedures are likely to be followed more often. Costs include a damage award or the reemployment of the employee.

All: Employers will finance at maximum the first six months of the unemployment benefit. In the Spring Agreement (BZ/2012/283M) it is stated that employers will finance one month per year of employment with a minimum of three months for workers with a permanent contract. Counted are only the years of employment with the concerned employee. The proposal of Minister Kamp remains silent about this issue.

tFor the period 2003-2009 an average of 35 repressive cases was filed in the Maastricht district.

In Chapter 4 we have calculated the costs of dismissal of the current system for both the PES route and the civil court route. In the current EPL system average total costs equal $€ 7,480$ for dismissal via the PES and $€ 30,982$ for dismissal via the civil court (see Chapter 4). When calculating the total average dismissal costs for the PES and the civil court together, we use the following rule:

${ }^{210}$ We do not take into account lawyer fees (see also Chapter 4). 
Average dismissal costs ${ }_{P E S}$

$$
=\frac{\sum_{i=1}^{n}\left(\text { Total dismissal costs per employe } e^{211}\right)}{n}
$$

,where $n$ equals 1,872 , which is the total number of cases granted at PES and at civil court in the years 2006-2009 (994 +878, see Chapter 4). Table 2 shows that the average total dismissal costs of the current system equal $€ 18,503$ per dismissed employee.

Table 2 Total average costs for PES and civil court together, current system ( $n=1,872,2006-2009)$.

\begin{tabular}{ll}
\hline Mean & $€ 18,503$ \\
Median & $€ 8,052$ \\
Std. Dev. & $€ 39,530$ \\
Minimum & $€ 97$ \\
Maximum & $€ 683,947$ \\
\hline
\end{tabular}

If the same sample of employees would have been fired under the new proposed measures, the following average firing costs would have been obtained:

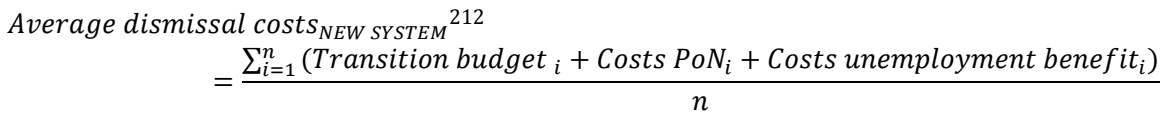

, where $n$ equals 1,872 and $i$ is the $i^{\text {th }}$ worker in our sample.

\footnotetext{
${ }^{211}$ Total costs for the PES procedure include: costs of procedure, costs of time to notice and the costs of the period of notice. Total costs for the civil court procedure include: court fee, costs of procedure, costs time to termination and the severance payment (see Chapter 4).

${ }^{212}$ The new proposed severance payment is calculated as follows:

$\begin{array}{ll}\text { Proposed severance }_{i}=1 / 4 \times \text { Gross monthly salary }_{i} \times \text { Tenure }_{i} & \text { for }_{\text {Tenure }}<=24 \text { years } \\ \text { Proposed severance }=6 \times \text { Gross monthly salary } & \text { for Tenure }\end{array}$
}

The costs for the period of notice are calculated as follows:

Costs period of notice $_{i}=$ Period of notice $_{i}$ (equals 2 for all workers) $x$ Gross monthly salary ${ }_{i}$ including $8 \%$ holiday fee. The costs of the unemployment benefit are calculated as follows:

Costs unemployment benefit $t_{i}=$ Unemployment history $_{i}$. Gross monthly salary constrained to a maximum m $_{i} A$ discount factor $_{i,}$, where Unemployment history $y_{i}$ is set to a maximum of 6 months.

When calculating the unemployment history we follow the proposal as stipulated in the Spring Agreement (BZ/2012/283M): An employer will finance one month per year of employment with a minimum of three months for workers with a permanent contract. Counted are only the years of employment with the concerned employee.

In our cost calculations we used the discount factors such a currently used in the calculation of the unemployment benefit. It equals 0.75 for the first two months of the unemployment benefit, and 0.70 after the first two months.

The gross monthly salary is constrained to a legal maximum, which equaled $168 €$ a day for 2006 (UB/K/2006/50248). Using the Consumer Price Index (2006=100) we calculated the real value of this amount for all other years. In order to calculate the (gross) daily salary we divided the (gross) yearly salary by 261 . All daily salaries above the maximum value were set at the maximum value. Daily salaries are converted to monthly salaries and are expressed in 2006 constant prices. 


\section{CHAPTER 7}

In the costs calculations of the new proposed system we assume that the employer does not incur ongoing wage costs before the period of notice commences. This is assumed because the abolishment of a preventative procedure. Table 3a shows the results of our calculations.

Table 3a Dismissal costs new proposed measures ( $n=1,872,2006-2009)$.

\begin{tabular}{lcccc}
\hline & Proposed severance & Costs PoN & $\begin{array}{c}\text { Costs unemployment } \\
\text { benefit }\end{array}$ & Total costs \\
\hline Mean & $€ 6,136$ & $€ 4,672$ & $€ 7,788$ & $€ 18,596$ \\
Median & $€ 3,588$ & $€ 4,236$ & $€ 7,564$ & $€ 15,545$ \\
Std. Dev. & $€ 7,101$ & $€ 2,927$ & $€ 3,928$ & $€ 12,584$ \\
Minimum & $€ 15$ & $€ 185$ & $€ 269$ & $€ 549$ \\
Maximum & $€ 86,521$ & $€ 34,258$ & $€ 15,652$ & $€ 136,359$ \\
\hline
\end{tabular}

Table 3b PES sample ( $n=994,2006-2009)$.

\begin{tabular}{lcccc}
\hline & Proposed severance & Costs PoN & $\begin{array}{c}\text { Costs unemployment } \\
\text { benefit }\end{array}$ & Total costs \\
\hline Mean & $€ 5,833$ & $€ 4,128$ & $€ 7,441$ & $€ 17,401$ \\
Median & $€ 3,688$ & $€ 4,044$ & $€ 7,266$ & $€ 15,207$ \\
Std. Dev. & $€ 5,825$ & $€ 2,173$ & $€ 3,800$ & $€ 10,847$ \\
Minimum & $€ 15$ & $€ 185$ & $€ 269$ & $€ 549$ \\
Maximum & $€ 51,370$ & $€ 22,830$ & $€ 15,652$ & $€ 84,145$ \\
\hline
\end{tabular}

Table 3c Civil court sample ( $\mathrm{n}=878,2006-2009)$.

\begin{tabular}{lcccc}
\hline & Proposed severance & Costs PoN & $\begin{array}{c}\text { Costs unemployment } \\
\text { benefit }\end{array}$ & Total costs \\
\hline Mean & $€ 6,480$ & $€ 5,287$ & $€ 8,180$ & $€ 19,948$ \\
Median & $€ 3,462$ & $€ 4,494$ & $€ 7,774$ & $€ 16,093$ \\
Std. Dev. & $€ 8,303$ & $€ 3,496$ & $€ 4,035$ & $€ 14,183$ \\
Minimum & $€ 39$ & $€ 444$ & $€ 487$ & $€ 1,033$ \\
Maximum & $€ 86,521$ & $€ 34,258$ & $€ 15,652$ & $€ 136,359$ \\
\hline
\end{tabular}

With an average total cost of $€ 18,596$, Table 3a shows that the costs of the new proposed EPL are not lower than the costs of the current system (t-statistic=0.10, $p=.93$ ). ${ }^{213}$ The financing of the first months of unemployment are the largest cost component of these total costs. A smaller standard deviation indicates that the uncertainty in costs is lower in the new proposed system.

Table $3 \mathrm{~b}$ and Table $3 \mathrm{c}$ split the total sample of requests into requests that were originally filed at the PES and requests that were originally filed at the civil court. Table $3 b$ shows that employers that originally selected the PES route will incur costs that are more twice as large ( $€$ 17,401 vs. $€ 7,480$ ) if the concerned dismissed employees would have been fired using the firing rules in the new system. Table $3 c$ shows that employers that originally selected the civil court route incur lower costs ( $€ 19,948$ vs. $€ 30,982$ ). The relatively high costs of the period of notice

${ }^{213}$ Unequal variances assumed. 
and the unemployment benefit are offset by the relatively low cost of the new severance payment.

Figure 1 shows the relationship between age and costs in the current system and in the new proposed system. Total dismissal costs for employees around the age of 55 are indeed lower in the new proposed system than in the current system. Both systems however, show that dismissal costs are a concave function of age, with a peak in dismissal costs of around the age of 55.

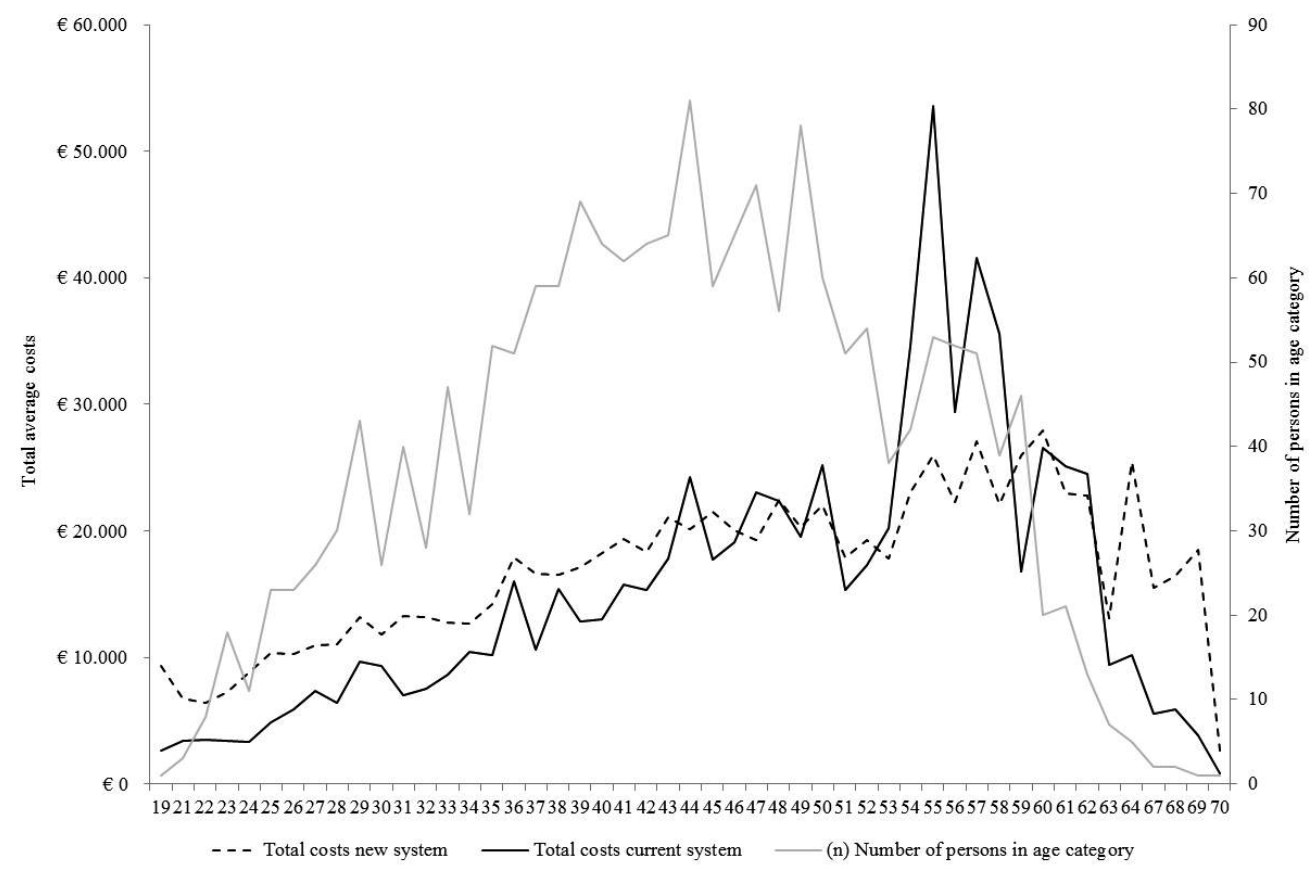

Figure 1 Age and average total costs, current system versus new proposed system ( $n=1,872 \dagger, 2006-2009)$.

+ We are careful in interpreting averages of employees below 23 and above 63 as the number of employees in those age categories are small.

The costs calculations in Table 3a-c and Figure 1 do not take into account the sector premium for the unemployment benefit fund that is suggested to be abolished after the modification. Because these costs are saved nevertheless and for all employees, we assume that these costs do not play a role in the firing decision itself. ${ }^{214}$ Moreover, both costs calculations of the current EPL (Table 2) and of the proposed EPL (Table 3a-c, Figure 1) do not take into account the possibility that an employee goes to court to protest against the dismissal. The possibility, however, that an employee files a lawsuit against his employer because of being unreasonably dismissed, is much larger in the new proposed system than in the current system because of the abolishment of the preventative check. Additionally, the cost calculations of the proposed

\footnotetext{
${ }^{214}$ We did calculate the average monthly costs that are saved because of the abolishment of this premium. Using the average sector premiums of 2009 , employers in our sample will save an average of $€ 23$ a month. Premiums differ per sector of employment. Not to complicate matters, we used the average premium of all sectors, which equals $1.05 \%$ of the gross salary, which is constrained to a maximum. As such, this $€ 23$ per month is a rough indication.
} 
system do not take into account the costs of the hearing procedure, of which the exact form and execution is not stipulated yet. On top of that, the expiry of a flexible contract will be costly for employers as also flexible workers are entitled to receive a budget. Additionally, the financing of the first months of unemployment benefit for flexible workers is incurred. As such, the costs of the new proposed system are expected to be even higher than presented here.

\subsection{Policy implications}

This dissertation has provided some useful insights in understanding the consequences of a possible modification and in showing that the plans of the government to modify EPL are based on untested premises. We provide a document that has some important policy implications. We object to the abolishment of the preventative check by the PES and the civil court and we advise the government to abandon the proposal to introduce a single repressive check by court.

First of all, we showed that over $90 \%$ of the requests that are filed at the PES and at the civil court are honored. This implies that the Dutch labor market is not as inflexible as believed. This high likelihood of success also indicates that over $90 \%$ of requests that are filed at the PES or at the civil court are based on reasonable grounds. This given, we argue that the preventative check acts as a barrier to put a halt to unfair dismissals. Policy makers should also realize that without a preventative check of dismissal employees are much more likely to file a repressive check. ${ }^{215} \mathrm{~A}$ higher possibility that a dismissed employee starts a repressive case in court, with the possible outcome of reestablishment of the employment contract or a damage award, results in higher insecurity for employers. This argument becomes even stronger when considering that it is possible to make an appeal against the decision of the court. As a result, employers may be confronted with costs years after the dismissal has taken place. ${ }^{216}$ Policy makers should additionally realize that in comparison to a repressive procedure, the current preventative procedure is a relatively fast and cheap procedure. ${ }^{217}$

The findings of Chapter 6 of this dissertation are in agreement with our earlier argument that the preventative check of dismissal acts as a barrier for unfair dismissals. We showed that recession induced cases that are filed at PES are weaker cases, and are less likely to be won by the employer. ${ }^{218}$ Without a preventative check to put a halt to these dismissals, times of economic slumps will elicit an increase in the number of workers that is dismissed unfairly and additional costs of unemployment are imposed on the Dutch society.

In Chapter 5 we argue that the Dutch dual system can be described as a system of a possibility of severance pay exemption for firms in economic distress. The government can decide to relieve firms from the obligation of severance payments during periods of economic contraction. The general point for policymakers to understand is that during periods of contraction the costs of unemployment contributions may exceed the costs of the government

\footnotetext{
${ }^{215}$ See also the research of Ichino et al.(2003) in which $21 \%$ of all dismissed employees at a large Italian bank file a lawsuit against their employer, but also the letter of the Legal Council as described on page 138 above.

${ }^{216}$ See also the letter of the delegation of scientists.

${ }^{217}$ The duration of a repressive procedure is long (see for instance www.specialistenplan.nl/artikel/vragen-inzakeontslag and http://www.kroon-partners.nl/Teksten/faq_tekst.html), retrieved October $2^{\text {nd }} 2012$.

${ }^{218}$ We define a weaker case as a case that does not, partly or fully comply with the definition of a fair dismissal as stipulated in Dutch law.
} 
relieving firms from severance pay. Combined with the notion that the existence of two routes of dismissal is on itself is a sign of flexibility, we argue that the duality of the Dutch system has some positive side-effects that are not directly visible and therefore not taken into account in the political discussion about the modernization of Dutch EPL.

The latest proposal states that the new modification will result in an increase in firing costs for some employers and in a decrease for others. This chapter shows that employers that originally selected the PES route will incur costs that are more than 2 times higher (€17,401 vs. $€ 7,480$ ) in the new proposed system. Employers that originally selected the civil court route incur lower costs ( $€ 19,948$ vs. $€ 30,982$ ). We show that the average costs of dismissal are not expected to decrease ( $€ 18,596$ vs. $€ 18,503$ ). This given, and if we use the definition of the OECD that expresses flexibility in terms of costs (OECD, 2004), we present the notion that the new proposed system is not more flexible. Furthermore, since smaller employees are more likely to follow the PES route, the costs of the new system will be mostly carried by this group. The proposal of minister Kamp does suggest that smaller employees may be exempted from the obligation to finance the first months of the unemployment benefit. The definition of smaller employees however, is not given. Furthermore, if costs increase with the number of employees employed, due to the fact that smaller employers are exempted from certain payments, employers may intentionally decide to keep their personnel record small. This will have negative consequences for economic growth.

Furthermore, minister Kamp argues that a decrease in firing costs for older employees will result in improved labor market mobility for this specific group. Minister Kamp fails to provide evidence for this argument. The opposite scenario is likely to occur. Due to a decrease in firing costs, older workers are more easily fired and replaced by younger workers. Since the proposed system also presents firing costs as an increasing function of age (see Figure 1), firing a younger employee remains less costly than firing an older counterpart. ${ }^{219}$

This dissertation helps policymakers to understand that arguments in favor and against a modification can always be found. After reading this dissertation it may be decided to follow the political mass and to introduce the new proposed measures, of which the costs and the consequences are unforeseeable. We however would strongly recommend to revise the proposal made and to abandon the abolishment of the preventative check. Additional arguments to take into consideration are the years of experience of both the PES and the civil court in dealing with dismissal affairs. The proposed EPL does not seem to be more flexible in terms of costs but also not in terms of procedural inconveniences. The judicial consequences of the hearing procedure are unknown. For a hearing procedure to function properly, however, one should not rely upon ad hoc arrangements but one should rather document the rules regarding this procedure in some source of law. In such a procedure both the employee and the employee will call in the advice of a lawyer. Before one realizes, a new privatized preventative check is created. This new check however, is merely an advisory check. It is not decisive for the outcome of the dismissal dispute because it is only the court that decides post hoc whether the dismissal is based on reasonable grounds.

Last, the fact that we outperform many other countries in terms of employment, participation and productivity despite of being marked with one of the strongest EPL for permanent workers should be taken into account. On the basis of the comparisons we made in

\footnotetext{
${ }^{219}$ Herewith we do not claim that firing costs should not be an increasing function of age (tenure).
} 
Chapter 5 of this dissertation it does not seem to be unreasonable to state that the Dutch labor market is an example that challenges modern theories of unemployment and worker protection.

\subsection{Outlook for future research}

We propose an outlook for further research. On the basis of Chapter 4 of this dissertation we propose to formulate a model that explains the strategic choice of employers. The expected costs of both procedures are used as input for this model. This model can be used for sensitivity analysis to assess the impact of a modification of EPL on the firing decision of employers.

We furthermore suggest on the basis of Chapter 5 of this dissertation to design a dynamic general equilibrium search model as in Landais et al. (2012). Such a model extended with cyclical severance pay exemption governmental policy is necessary to perform analyses of the influence of government policy on job protection during periods of economic expansion and recession separately.

Additionally, we propose further analyses to provide additional insights into the effect of the proposed modification more specifically. Important questions to be answered are:

Do the high firing costs of older employee result in lower labor market mobility of this specific group or are there other factors that play a role?

To what extent is the high performance of the Dutch labor market due to the fact that the Netherlands has very flexible rules for workers with flexible contracts?

What is the effect of an increase in firing costs for workers with a flexible contract? Will an increase in costs result in a larger proportion of workers with a permanent contract or will an increase in costs lead to more unemployment?

What is effect of the abolishment of the preventative check on the number of workers that file a lawsuit against their employers in court after being dismissed?

What are the costs of such a lawsuit for the employer?

To what extent do schooling and other routes that stimulate a person's capability for gaining and maintaining employment affect the influx of unemployed workers into employment?

To our view it is imperative to find answers to these questions. From a micro-perspective, this is essential because it allows for a deeper understanding of how firing and hiring decisions are made by the individual employer. The answers to question 4 and 6 provide insight into how individual employees find their way back to work after being dismissed. More specifically, an answer to question 4 shows how much employees are willing to file a case against their employer after being dismissed. It can furthermore be used to estimate the additional workload of the civil courts due to an extra inflow of repressive cases. With respect to question 6 , we argue that it is naïve to believe that a budget of a maximum of six months of the gross monthly salary to spend on schooling will significantly improve the labor market position of workers. 
Especially for older workers that have a long employment history with their previous employer this seems implausible.

From a macro-perspective, these questions are important because they test the critical assumptions on which the new proposal is based and allow for a better understanding of the effect of EPL on the functioning of the Dutch labor market.

Because the Dutch situation is unique, policy implications of research that is conducted in a different setting than the Dutch should be judged critically. Not only because the consequences of the new proposal are large: 1) The PES and the civil court preventative check are abolished, which will result in the destruction of PES and civil court jobs. 2) The law is modified. Dutch Law is a web of rules that are all carefully connected to each other. Proposing a new laws is complicated and time-consuming. 3) The new system introduces new costs as employers are made responsible for the financing of the first months of the employment benefits. As such, firing decisions will be made differently, especially for smaller employers for whom firing costs will rise. 4) Because the new severance budget is supposed to be used for schooling and other routes that stimulate a person's capability for gaining and maintaining employment, the spending of the budget has to be monitored. Monitoring is again costly.

Care with the implementation of new policies is also a must because it is difficult to undo the measures once implemented. Especially in times of economic downturn we advise policymakers not to 'experiment' with EPL and social welfare.

\subsection{Conclusion}

The discussion about the modification of the Dutch EPL should not be about decreasing employment protection on itself; it should be about the question which policies will ensure an optimal functioning of the Dutch labor market. Herewith one should take into consideration the society as a whole. We understand that employers would prefer to see firing costs decrease and that employees are in favor of gaining more protection. We also understand that political parties use the topic of EPL to win votes. Left-wing parties are expected to protect the rights of the worker or the weaker party, whereas the more right-wing and liberal parties are expected to be in favor of a relaxation of EPL.

We however, are against the abolishment of the preventative check. The analyses conducted in this dissertation learn that:

The Dutch system is more flexible than the government presents it to be as over $90 \%$ of all dismissal requests is honored.

The Netherlands outperforms other EU countries in terms of high participation, low unemployment and high productivity.

A repressive check leads to additional procedural inconveniences for employers because of the uncertainty of being sued post hoc. As such, a repressive system is not by definition a more flexible system.

Preventive dismissal checks put to halt to recession induced cases that have no reasonable ground. 


\section{CHAPTER 7}

Preventative dismissal checks restrain firms to seek reduction of severance payments on unjustifiable grounds. Consequently, firms are discouraged to shift private costs to society on considerations of self-interest alone. Costs of moral hazard are reduced.

The unique Dutch system of severance pay lenience for firms in distress is cost effective, implying that a labor market policy with severance payment exemption is less costly than the alternative of additional employment benefits. ${ }^{220}$

The proposed system will not lead to a decrease in firing costs.

Political parties rely upon a modification of EPL as a medicine to stimulate economic recovery. They focus on short-term effects and are driven by sentiment. Criticism against the abolishment of the preventative check is not taken into account and plans are not revised because of fear of being condemned for a lack of political backbone.

${ }^{220}$ We showed that this holds true when the wage elasticity of demand does not exceed the inverse of the replacement ratio. 
CHAPTER 8:

A BRIEF UPDATE 


\subsection{Introduction}

In the previous chapter we have commented on the proposed modifications of the Kunduz parties VVD, CDA, D66, GroenLinks and ChristenUnie. Recent political developments have motivated us to write a brief update. As mentioned in the previous chapter of this dissertation, a general election was held on September $12^{\text {th }} 2012$. The VVD received the majority of the votes, followed by the PvdA. The Coalition Agreement of the $29^{\text {th }}$ of October 2012 that was formed by both parties deviates from the proposed modifications as presented earlier by the Kunduz parties. In short, the most important measures in the Coalition Agreement for dismissal protection are:

1. The preventative check of dismissal by the public employment service $(P E S)^{221}$ is maintained ${ }^{222}$, the parallel preventative check by the civil court is lapsed. Criteria for reasonable dismissal are being accurately described. ${ }^{223}$ The duration of the PES procedures is shortened with two weeks. The dismissal permission of the PES is replaced by a dismissal advice, which is not binding.

2. The civil court preventive route is followed in the event of the existence of a dismissal prohibition. ${ }^{224}$

3. In the event of a dismissal or the decision not to renew a temporary employment contract for at least a year the employer is obliged to pay a transition budget for training, unless the dismissal is driven by financial reasons and the employer runs the risk of bankruptcy when complying with that obligation. The transition budget equals a quarter of a monthly salary for each year employed and is constrained to maximum of four monthly salaries. ${ }^{225}$

4. Dismissed employees may apply to the civil court (repressive check). ${ }^{226}$ If the court finds the dismissal unreasonable, it may award a compensation which equals half a monthly salary, at most, for each year of service. It has an upper limit of 75,000 euros gross. If the employer has not followed a negative advice of the PES, the court may recover the employment relationship. There is no appeal possible against the court decision.

5. The maximum eligibility period for unemployment benefits is 24 months. ${ }^{227}$ Unemployment premiums will increase.

6. The legal period of notice of 1 to 4 months, dependent on years of employment, is maintained.

The proposed measures in the Coalition Agreement of October 2012 are less drastic than the measures proposed by the Kunduz political parties in May 2012. Following our reasoning in

\footnotetext{
${ }^{221}$ In this chapter PES is used as an acronym for public employment service.

222 The obligation of a preventative check does not apply when the collective bargaining agreement provides a similar procedure.

${ }^{223}$ The current dismissal criteria for economic dismissals are being upheld.

${ }^{224}$ An employer may also turn to court when intending to terminate a fixed term contract when the option of termination is not included in the employment contract.

${ }^{225}$ The transition budget is also awarded when not extending a fixed term contract of at least one year.

${ }^{226}$ The advice of the UWV is strongly considered. Dismissal criteria of the civil court will be identical to the dismissal criteria of the PES.

${ }^{227}$ Of which 12 months are related to the most recent wage and 12 months are related to the statutory minimum wage.
} 
Chapter 5 to 7 of this dissertation, we agree with the maintenance of the preventative check of dismissal and the exemption of severance payment for firms in financial distress. First, because a preventative check puts a halt to unfair dismissals, and second, because a system of severance pay lenience for firms in economic distress is cost-effective (see Chapter 5). We also argue that the proposed measures have some drawbacks.

This short chapter is structured as follows. Section 2 shows a calculation of costs of the measures proposed in the Coalition Agreement. In Section 3 we present our own point of view. Section 4 concludes.

\subsection{Some cost calculations}

Following Chapter 7, Section 5 of this dissertation we calculate the costs of the measures proposed in the Coalition Agreement, using our sample of 994 PES dismissals and 878 civil court dismissals. ${ }^{228}$ Table 1 shows a schematic overview of the differences in costs of the current and of the new proposed system. Average dismissal costs of the Coalition Agreement measures are calculated as follows:

Average dismissal costs

$$
=\frac{\sum_{i=1}^{n}\left(\left(A 1_{i}+A 2_{i}+A 3_{i}\right) \text { Salary }_{i}+\text { Transition budget }_{i}\right)}{n}
$$

,where $n$ equals 1,872 and $i$ is the $i^{\text {th }}$ worker in our sample. A1 refers to the duration of the PES procedure. $A 2$ refers to the time to notice, and $A 3$ to the period of notice (see Chapter 4 for a more detailed description of $A 1, A 2$ and $A 3$ ). Salary is the gross monthly salary including a holiday payment of $8 \%$.

Table 2a shows that the costs of the Coalition Agreement measures are $€ 11,166$. These costs are lower than the $€ 18,503$ average costs of the current system. The ongoing wage costs during the extended period of notice are the largest cost component. Because the transition budget is not an obligatory payment for firms in financial distress, total costs for economic dismissals are lower than for non-economic dismissals ( $€ 8,754$ vs. $€ 13.619$, respectively. Not presented in table). ${ }^{229}$

\footnotetext{
${ }^{228}$ Herewith, we realize that different firing costs may result in a different selection of employees to be dismissed. As such, we do not claim that a similar selection of employees is dismissed in the new proposed system. For example, our calculations show that employers that selected the PES route are confronted with dismissal costs that are twice as high when using the proposed firing rules. These employers may depart from dismissing certain employees for which firing costs increase in the new system. Our purpose in this chapter is only to show how the new rules may be applied, ceteris paribus.

${ }^{229}$ When calculating the costs for economic dismissals we set all transition budgets equal to zero.
} 
Table 1 Overview of cost differences of current system and measure in the Coalition Agreement.

\begin{tabular}{|c|c|c|}
\hline & $\begin{array}{l}\text { Current employment protection } \\
\text { legislation (EPL) }\end{array}$ & $\begin{array}{l}\text { Measures as proposed in the Coalition } \\
\text { Agreement }\end{array}$ \\
\hline Severance payment & $\begin{array}{l}\text { Civil court: According to the civil court } \\
\text { formula }(A \times B \times C) \text { PES: Severance pay is } \\
\text { not awarded }\end{array}$ & $\begin{array}{l}\text { All: Budgets instead of severance payments. } \\
\text { These budgets are set to maximum of four } \\
\text { months and equal a quarter of a monthly salary } \\
\text { per year of employment. Both permanent and } \\
\text { flexible workers are entitled to receive the } \\
\text { budget. }\end{array}$ \\
\hline Period of notice (PoN) & $\begin{array}{l}\text { Civil court: None, the date of } \\
\text { termination of the contract is } \\
\text { determined by court. Ongoing wage } \\
\text { costs are incurred during this period. } \\
\text { PES: } 1 \text { to } 3 \text { months, dependent on years } \\
\text { of employment with the concerned } \\
\text { employer. Ongoing wage costs during } \\
\text { the PoN are incurred. Ongoing wage } \\
\text { cost are also incurred during the time in } \\
\text { between date at which the case is } \\
\text { closed and the date at which the PoN } \\
\text { commences (see Chapter 4). }\end{array}$ & $\begin{array}{l}\text { All: The statutory period of notice (PoN) of } 1 \text { to } \\
4 \text { months is used. The PoN is dependent upon } \\
\text { the years of service (see Chapter 2, Table 2). } \\
\text { Ongoing wage costs during the PoN are } \\
\text { incurred. Ongoing wage cost are also incurred } \\
\text { during the time in between date at which the } \\
\text { case is closed and the date at which the PoN } \\
\text { commences (see Chapter 4). }\end{array}$ \\
\hline $\begin{array}{l}\text { Costs of preventative } \\
\text { procedure }\end{array}$ & $\begin{array}{l}\text { Civil court: Ongoing wage costs are } \\
\text { incurred during the duration of the } \\
\text { procedure. } \\
\text { PES: Ongoing wage costs are incurred } \\
\text { during the duration of the procedure }\end{array}$ & $\begin{array}{l}\text { All: Ongoing wage costs are incurred during the } \\
\text { duration of the procedure. }\end{array}$ \\
\hline $\begin{array}{l}\text { Costs of repressive } \\
\text { procedure }\end{array}$ & $\begin{array}{l}\text { Repressive procedures are not often } \\
\text { followed in the current system. }\end{array}$ & $\begin{array}{l}\text { Repressive procedures are likely to be followed } \\
\text { more often. Costs include a damage award or } \\
\text { the reemployment of the employee. }\end{array}$ \\
\hline $\begin{array}{l}\text { Costs of unemployment } \\
\text { benefit }\end{array}$ & $\begin{array}{l}\text { All: Employers pay an unemployment } \\
\text { premium for all their employees. } \\
\text { Employers do not finance the first } \\
\text { months of the unemployment benefit. }\end{array}$ & $\begin{array}{l}\text { All: Employers pay an unemployment premium } \\
\text { for all their employees. These premiums will } \\
\text { increase. }\end{array}$ \\
\hline
\end{tabular}

Tabel 2a Total average costs for PES and civil court together, Coalition Agreement ( $n=1872,2006-2009)$.

\begin{tabular}{lccccc}
\hline & $\begin{array}{c}\text { Wage costs } \\
\text { duration process }\end{array}$ & $\begin{array}{c}\text { Wage costs time } \\
\text { to notice }\end{array}$ & Wage costs PoN & Transition budget & Total costs \\
\hline Mean & $€ 2,248$ & $€ 907$ & $€ 5,591$ & $€ 2,421$ & $€ 11,166$ \\
Median & $€ 1,792$ & $€ 754$ & $€ 4,027$ & $€ 0$ & $€ 8,632$ \\
Std. Deviation & $€ 2,351$ & $€ 698$ & $€ 5,163$ & $€ 4,481$ & $€ 10,227$ \\
Minimum & $€ 0$ & $€ 9$ & $€ 93$ & $€ 0$ & $€ 206$ \\
Maximum & $€ 28,711$ & $€ 6,749$ & $€ 68,374$ & $€ 68,374$ & $€ 159,571$ \\
\hline
\end{tabular}

Table $2 \mathrm{~b}$ shows that employers that originally selected the PES route will incur costs that are equal to $€ 9,254$. Total costs for economic dismissals and for non-economic dismissals equal $€$ 8,096 and $€ 12,327$, respectively (not presented in table). In Chapter 4 of this dissertation we 
showed that average dismissal costs via the PES route in current system equal $€ 7,480$. Costs for economic and non-economic dismissals equal $€ 7,532$ and $€ 7,339$, respectively. As such, the measures of the Coalition Agreement will lead to an increase in costs for employers that originally followed the PES route. These employers are generally smaller in size than those that follow the civil-court route.

Table 2b PES sample ( $n=994,2006-2009)$.

\begin{tabular}{|c|c|c|c|c|c|}
\hline & $\begin{array}{l}\text { Wage costs } \\
\text { duration process* }\end{array}$ & $\begin{array}{l}\text { Wage costs time } \\
\text { to notice }\end{array}$ & Wage costs PoN & Transition budget & Total costs \\
\hline Mean & $€ 2,036$ & $€ 787$ & $€ 5,247$ & $€ 1,185$ & $€ 9,254$ \\
\hline Median & $€ 1,198$ & $€ 583$ & $€ 4,032$ & $€ 0$ & $€ 7,296$ \\
\hline Std. Deviation & $€ 2,815$ & $€ 685$ & $€ 4,197$ & $€ 2,744$ & $€ 7,468$ \\
\hline Minimum & $€ 0$ & $€ 9$ & $€ 93$ & $€ 0$ & $€ 206$ \\
\hline Maximum & $€ 28,711$ & $€ 3,948$ & $€ 34,246$ & $€ 21,316$ & $€ 66,335$ \\
\hline
\end{tabular}

* In order to calculate the duration of the process, we used the average duration of the PES procedure as presented in Chapter $4 a$, and subtracted 14 days.

Table 2c Civil court sample ( $n=994,2006-2009)$.

\begin{tabular}{lccccc}
\hline & $\begin{array}{c}\text { Wage costs } \\
\text { duration } \\
\text { process* }\end{array}$ & $\begin{array}{c}\text { Wage costs time } \\
\text { to notice** }\end{array}$ & Wage costs PoN & $\begin{array}{c}\text { Transition } \\
\text { budget }\end{array}$ & Total costs \\
\hline Mean & $€ 2,488$ & $€ 1,042$ & $€ 5,980$ & $€ 3,820$ & $€ 13,330$ \\
Median & $€ 2,115$ & $€ 885$ & $€ 4,022$ & $€ 2,032$ & $€ 9,636$ \\
Std. Deviation & $€ 1,645$ & $€ 689$ & $€ 6,053$ & $€ 5,533$ & $€ 12,294$ \\
Minimum & $€ 209$ & $€ 88$ & $€ 222$ & $€ 0$ & $€ 519$ \\
Maximum & $€ 16,123$ & $€ 6,749$ & $€ 68,374$ & $€ 68,374$ & $€ 159,571$ \\
\hline
\end{tabular}

* In order to calculate the duration of the process, we used the average duration of the PES procedure as presented in Chapter $4 a$, and subtracted 14 days.

** For the time to notice we used the average PES time to notice.

In the current system average total costs for employers that followed the civil court route are $€$ 30,982 . Costs for non-economic dismissals and economic dismissals are $€ 26,918$ and $€ 42,994$ respectively. Table $2 \mathrm{c}$ shows that total costs for employers that followed the civil court route in the current system will decrease to $€ 13,330$. Costs for non-economic dismissals and economic dismissals are $€ 14,154$ and $€ 10,895$, respectively. This given, costs for employers that originally followed the civil court route of dismissal will decrease because of the measures proposed in the Coalition Agreement.

\subsection{Our point of view}

In our point of view the proposed measures in the Coalition Agreement are an improvement of the measures that were presented by Minister Kamp (See Chapter 7 for an overview these measures). We, however, also argue that the newly proposed measures have some drawbacks. 
First, because high severance awards are being replaced by relatively low transitory budgets and unemployment benefits are being heavily reduced, the likelihood that employees apply to court for dismissal compensation is highly likely to increase. This likelihood moreover increases due to the fact that the dismissal permission of the PES is replaced by a dismissal advice, which is not binding. ${ }^{230}$

Second, as we have presented in Chapter 5 of this dissertation, the PES and the civil court are specialized in handling cases with different backgrounds. The PES mainly processes economical cases and cases due to long-term illness. The civil court mainly deals with dismissal disputes that are due to a disturbed relationship. A reason that the civil court is more specialized in disturbed relationships is because the criteria for the reasonableness of such dismissal are less obvious than those for economic dismissals. The PES has strict dismissal criteria to follow, the set of rules followed by the civil court is broader and more generic and thus leaves more room for interpretation. Moreover, the civil court may increase the severance payment if it judges the employer to be culpable. Additionally, the PES procedure is a procedure in writing. Judgment of disturbed relationship disputes is difficult in such a procedure. Court hearings are more informative in this respect. The new proposed measures as such require a modification of the current PES route. Furthermore, as Adam Smith recognized long time ago, specialization in general leads to more efficiency. As such, abolishing the dual system is inefficient.

Third, a dismissal permission for cases due to a disturbed relationship requires detailed evidence. And, as we mentioned above, cases of disturbed relationships are more difficult to capture in criteria. In the current system, dismissal cases that do not exactly comply with the PES-criteria end up at court (with accompanying higher severance payments). This is no longer an option in the new system. From the perspective of creating a more flexible EPL, dismissal in such cases will be more difficult instead of less difficult.

Fourth, cost will not decrease for all employers. As we have showed in Table $2 b$ of this chapter, costs for employers that originally followed the PES route will increase. As such, costs of the new system will mainly be carried by smaller employers.

\subsection{Conclusion}

This chapter has given a brief update of the proposed measures as presented in the Coalition Agreement of the $29^{\text {th }}$ of October 2012. Although the measures of the Coalition Agreement are less drastic than the measures proposed by the Kunduz parties that we described in Chapter 7 of this dissertation, the newly proposed measures have some drawbacks. These drawbacks are mostly related to the option of choice that employers have in the current system. If the newly proposed measures will be transformed into law, this option of choice disappears. As we argued earlier, the existence of two routes of dismissal on itself is a sign of flexibility. Abolishing this option of choice leads to less flexibility because decisions have to be made under stricter requirements. Furthermore, we would like to stress the fact that both institutes are specialized

\footnotetext{
${ }^{230}$ Additionally, recovery of the employment contract by the court is only possible after a negative PES advice. After a positive PES advice the concerned employee may only be awarded a compensation. This seems unfair in the event that the PES has mistakenly given a positive advice. This event will be rare, but one should not forget that the assessment of dismissal cases is a human job.
} 
in assessing a different type of case. The PES mainly reviews economic dismissals and dismissals due to illness. The civil court mainly deals with cases of disturbed employment relationships. Economic theory predicts that specialization in general leads to efficiency. Also important to note is that one will destroy a system that has functioned relatively well and that has developed itself over the past 60 years. Over time adaptations have been made to improve the legal system as founded in 1838. A new proposed system is likely to lead to new unforeseen drawbacks.

In the new system, because the PES advice is a non-binding advice, a large responsibility is shifted to the employee. If an employer decides to fire a employee despite of a negative dismissal advice, the employee has to take the initiative to apply to court to be re-employed or to receive a compensation. For some employees this is a high barrier to cross, and some will lose their job unfairly.

Because the proposed measures are not described in great detail the Coalition Agreement provokes many questions, such as: What if employers fire an employees without an advice of the PES? What will happen to the pro-forma procedure that is now often followed at the civil court? Will the regulation regarding summary dismissal be modified?

The newly proposed measures also contain some positive aspects. First, the inequality of severance payments disappears. In the proposed system, receiving severance payments is not dependent upon the route of dismissal and is equal for all employees with the same background in terms of tenure and reason for dismissal. Most important, the preventative check of dismissal does not disappear. As we mentioned earlier throughout this dissertation, we are a strong advocate of such a check. 

CHAPTER 9:

CONCLUSION 
The Dutch employment protection legislation is unique in the world. It so happens that firms in the Netherlands have two different possibilities to seek to dissolve a tenured worker contract. One possibility is to ask for permission from the public employment service (PES) ${ }^{231}$. The other possibility is to request the universal civil court for a dismissal permission ${ }^{232}$. The PES is a governmental institution, and remains from a decree that has been enforced during the occupation of the Netherlands during World War II. After the war a provisional law was proclaimed to maintain the decree and the uniqueness of it is that it still exists. The OECD refers to the Dutch system as a dual system of dismissal.

In Chapter 2 of this dissertation we sketch a short overview of the history of Dutch employment protection legislation $(E P L)^{233}$. We explain that the first route of dismissal, the civil court route, exists since the introduction of article $1639 \mathrm{w}$, which was part of the Law on Employment Contracts of 1907. After some modifications that broadened the possibilities of the civil court to dissolve a contract, article $1639 \mathrm{w}$ (old CC) would later become article 7:685 (CC), the article on which the current civil court route is based. The PES route of dismissal found its origin some 50 years later when the Dutch government upheld a decree of the occupying Germans, which recorded a dismissal prohibition. This prohibition stipulated that an employer could not dismiss an employee without the approval of the Labor Inspectorate. For dismissal a reasonable cause was required. If the Labor Inspectorate judged dismissal to be unreasonable, permission to terminate the employment contract was not given. Today, the task of the Labor Inspectorate is performed by the PES, for which the Dutch official name is the Uitvoeringsinstituut Werknemersverzekeringen (UWV). Uniquely, and after several attempts of abolishment, the Dutch system still exists today.

The idea for this dissertation stems from one of the latest attempts to modify the Dutch system. With the need to increase labor participation, former Minister of Social Affairs and Employment, Minister Donner, proposed a simplification of the Dutch system in 2007. According to the Minister, the Dutch EPL inhibits employers from employing new employees. One of the most important suggestions made is that prior approval from the UWV and the civil court is not needed. ${ }^{234}$ Minister Donner's proposal led to a political impasse. Dutch EPL is left untouched.

We argue that an important cause for the fact that the dual system still exists today is that it is difficult to predict what will happen if the Netherlands converts to another dismissal system. In fact, we do not know what is the effect of EPL on labor market outcomes. See for instance the overview of Addison and Teixeira (2003) to understand how many different conclusions are drawn. We furthermore observed that the Dutch system deserves some special attention. The unique aspects of the system have received too little attention. First of all, we argue that the existence of two routes of dismissal on itself is a sign of flexibility. Employers have the option to choose. Abolishing this option of choice leads to less flexibility because decisions have to be made under stricter requirements. Moreover, we noticed that the Dutch labor market, despite of being marked with one of the strongest regulations for workers with a permanent contract,

\footnotetext{
${ }^{231}$ In this chapter PES is used as an acronym for public employment service.

${ }^{232}$ As mentioned earlier, an employment contract may also be terminated at will during the trial period, by mutual consent, by operation of law and by summary dismissal. These options are beyond the scope of this dissertation.

${ }^{233} \mathrm{EPL}$ is used as an acronym for employment protection legislation.

${ }^{234}$ Without prior approval, however, a damage pay for the dismissed employee is made obligatory. When dismissal is due to economic grounds, the employer is relieved from the obligation to award the employee a damage pay, but only when the PES has granted a priori approval.
} 
outperforms most other EU15 countries, in terms of unemployment, labor participation and worker productivity. A last reason to work on this topic, is that we noticed that although the Dutch discussion on labor market flexibility is mainly a discussion about firing costs, an up-todate overview of such costs is not available.

During the process of writing this dissertation we have collected a unique sample of 3,391 individual dismissal cases, of which 1,134 requests are filed at the PES in the period 2006 to 2009 and 2,257 requests are filed at the civil court in the period 2003 to 2009 . Using this novel data set, this dissertation has quantified some of the major unique aspects of the Dutch system. First, in Chapter 4 we show that the average firing costs for the civil court procedure are four times larger than the average firing costs at the PES. The median costs are twice as large. The most striking difference, however, is found in the uncertainty of the outcomes between the two procedures. The standard deviation of the firing costs through the civil court is 10 times larger than for the PES. Thus the uncertainty (variance) associated with PES firing costs is one percent of the uncertainty for the cases that are judged by the courts.

In Chapter 5, we use Eurostat data to show that the Netherlands outperforms most other European countries in terms of unemployment, labor participation and productivity. This is contrary to the common belief that modern labor markets with strict protection laws for workers with permanent contracts have high unemployment, low labor participation, and low worker productivity. Next, we introduce the idea that the dual Dutch system can be typified as a system of government transfers to firms in demise, since firms that are granted permission of the PES are relieved from the obligation of severance pay. The PES checks if a dismissal request is reasonable. This provision of the PES is one the most important disciplinary instruments currently available for the Dutch labor market as it prevents firms in demise to seek a reduction of severance payments for unjustifiable reasons, and it reduces the costs of a firm's moral hazard to lay-off a worker at will. Last, we present a simple theoretical equilibrium model. The model predicts that as long as the wage elasticity of labor demand does not exceed the inverse of the replacement ratio a system of governmental transfer is less costly than additional unemployment benefits. We show that the likelihood for this condition to hold is high and increases when a firm is hit by a negative shock.

In Chapter 6 we show that recession induced cases that are filed at the PES are weaker cases from a plaintiff's perspective. These weaker cases, however, have a larger likelihood of being rejected. These results are desirable because it prevents a firm to dismiss without a reasonable cause.

In Chapter 7 we discuss the latest Kunduz proposal for the revision of the Dutch EPL. ${ }^{235}$ History repeats itself as the abolishment of the preventative dismissal check is suggested. We sketch an overview of the reactions the new proposal has provoked. Amongst those reactions was a letter of protest that was sent by a delegation of scientist to the Upper Chamber on June 12th 2012. We moreover present opinions from a workers' employers' and voters' perspective. Employers expect that a more flexible employment protection system will facilitate hiring, employees are afraid to be fired without a cause.

\footnotetext{
${ }^{235}$ In the Spring Agreement of May 2012 the Kunduz-parties VVD, CDA, D66, GroenLinks and ChristenUnie proposed a new drastic revision of the current Dutch EPL. This proposal was revised and sketched in more detail by Henk Kamp, (outgoing) Minister of Social Affairs and Welfare and was send to the Upper Chamber at the $18^{\text {th }}$ of June 2012. The most important measure introduced is the abolishment of the preventative check of dismissal (See Chapter 7).
} 
To our view, the dual preventative check should not be abolished and be replaced by a repressive check. First of all, we argue that the arguments used to modify the Dutch EPL are based on untested premised. As mentioned earlier, little is known about the effect of a possible modification. Second, a system with only a repressive check is not per definition less rigid. A repressive check itself is also costly. It might be easier to dismiss a worker, but this worker is likely to fight back in court. We know from the Italian system that $21 \%$ of all workers file a lawsuit against their employer after being dismissed (Ichino, Pollo and Rettore, 2003). Without the preventative check the Netherland might face similar post hoc suing rates as Italy. Moreover, Ichino et al. found that employees are more likely to file a lawsuit against their employer during recessions. These cases tend to be weaker ${ }^{236}$. This is not a desirable phenomenon as judicial costs for lawsuits then rise during recessions. Because of the possibility of post hoc law suits, repressive checks lead to uncertainty as both employers and employees may be faced with costs long after the dismissal has taken place. Third, a repressive check stimulates a firm to fire without a reasonable cause as not all unrightfully dismissed employees will file a lawsuit against their employer after being dismissed. The current preventative check encourages employers to carefully motivate the dismissal intention. A halt is put to unfair dismissals and it restrains firms to seek a reduction of severance payment on unjustifiable grounds. Fourth, we showed that the unique Dutch labor market policy with severance payment exemption by the PES is less costly than the alternative of additional employment benefits. ${ }^{237}$ It moreover reduces the costs of a firm's moral hazard. Fifth, the proposed system will not lead to a decrease in firing costs.

Last, Chapter 8 presents a brief update of recent political developments. The Coalition Agreement of the $29^{\text {th }}$ of October 2012 that was formed by political parties VVD and PvdA, who received the majority of the votes during the general elections of September 2012, deviates from the proposed modifications as presented earlier in Chapter 7. The proposed measures in the Coalition Agreement of October 2012 are less drastic than the measures proposed by the Kunduz political parties in May 2012. ${ }^{238}$ We argue that we agree with the maintenance of the preventative check of dismissal of the PES and with the exemption of severance payment for firms in financial distress. We agree with the former measure because a preventative check puts a halt to unfair dismissals. We agree with the latter measure because of our earlier mentioned argument that a system of severance pay lenience for firms in economic distress is cost-effective (see Chapter 5). We also argue that the proposed measures have some drawbacks. The option of choice disappears and a system in which both the PES and the civil court specialize in handling specific types of requests is abolished. The PES mainly deals with cases of long-term illness and economic circumstances. The civil court mainly processes cases of disturbed

\footnotetext{
${ }^{236}$ The theoretical explanation for this finding is that when the unemployment rate rises, the duration of unemployment spells increases, which prompts for higher damages awarded when the employment dispute is won. These higher damage pays increase the expected value of a case and could induce low probability cases to file suit (Ichino et al., 2003).

${ }^{237}$ We showed that this holds true when the wage elasticity of demand does not exceed the inverse of the replacement ratio.

${ }^{238}$ The most important measures presented in the agreement are 1) the maintenance of the preventative PES check of dismissal and the abolishment of the civil court preventative check, and 2) the obligation of the employer to award the employee a transition budget, unless he runs the risk of bankrupt by complying with that obligation. 3)The maximum eligibility period for unemployment benefits is reduced. (For a more detailed description of all measures that are recorded in the agreement see Chapter 8)
} 
relationships. The qualification of the PES to decide in cases of long-term illness and economic circumstances has a long history. The same holds true for the qualification of the civil court to decide in situations of disturbed relationships. From economic theory we know that specialization leads to efficiency. As such, abolishing the dual system is inefficient. Furthermore, because of the relatively low transitory budgets and the heavily reduced unemployment benefits in the new system, the likelihood that a repressive check is followed is likely to increase as compared to the current situation. Moreover, for some dismissals it is hard to capture a reasonable dismissal into strict criteria (e.g. dysfunctional behavior). In such cases the civil court, who applies broader criteria, provides a good alternative for the PES, who applies much stricter criteria.

On the basis of this dissertation, we propose an outlook for further research. On the basis of Chapter 4 we propose to formulate a model that explains the strategic choice of employers. This model is to be used for sensitivity analysis to assess the impact of a modification of EPL on the firing decision of employers. On the basis of Chapter 5 of this dissertation we propose to design a dynamic general equilibrium search model as in Landais et al. (2012) to perform analyses of the influence of government policy on job protection during periods of economic expansion and recession separately. Additionally, we suggest to perform additional empirical analyses to study the consequences of the proposed modifications more specifically.

This dissertation has its limitations. We only witness dismissal cases via the PES and the civil court route. Instead of going to court or the PES, the contract of a worker can also be terminated by mutual agreement. These cases we do not observe. We furthermore do not observe the decision making process preceding the decision to file a case at court or at the PES. We only observe that the PES route is the cheapest route to follow. From an economic perspective and taking into account only these costs, one would expect all firms to follow the PES procedure. As we have shown in Chapter 4 of this dissertation, for a specific individual case, however, the civil court route might be a cheaper route to follow. When deciding to file a request at either the civil court or the PES, a firm makes a strategic choice and will follow that route that has the lowest expected costs. The unobservable characteristics of a dismissal request play a large role in this decision. As we do not have information on these unobservable characteristics, we were not able to model the decision process of firms. Such a model would allow for a better understanding of the working of the Dutch system. The notion however, that the Dutch system allows firms to choose strategically is an additional indication of labor market flexibility.

We would like to conclude with the notion that we are not against a modification of Dutch EPL in general. Harmonization with the European (repressive) model is however dangerous as the efficiency of the Dutch model might suffer from modifications that are based on opinions instead of scientific proof. This mentioned, we recommend to leave the dual basis of the Dutch system untouched. This dual basis, together with a preventative check might be a blessing in disguise and an example for other European countries. 



\section{NEDERLANDSE SAMENVATTING (DUTCH SUMMARY)}

Een werkgever in Nederland heeft twee mogelijkheden om een arbeidsovereenkomst te beëindigen. Enerzijds kan hij de kantonrechter verzoeken de arbeidsovereenkomst te ontbinden. Als alternatief is er de mogelijkheid tot het aanvragen van een ontslagvergunning via het UWV WERKbedrijf. ${ }^{239}$ Dit stelsel wordt ook wel een duaal stelsel genoemd en is uniek in de wereld. De ontslagaanvraag wordt voorafgaand aan het ontslag getoetst en is dus een preventieve toets. Als gevolg zijn het UWV WERKbedrijf en de kantonrechter in een relatief vroege fase bij het ontslag betrokken. Als een werkgever heeft gekozen voor de UWV-route en het UWV verleent geen toestemming, kan hij zich altijd nog kan wenden tot de kantonrechter, en vice versa.

Het UWV WERKbedrijf volgt de regels die zijn opgenomen in het Buitengewoon Besluit Arbeidsverhoudingen (BBA) 1945 en het Ontslagbesluit. Een ontslagvergunning wordt afgegeven als het voorgenomen ontslag redelijk is bevonden. Voorbeelden van redelijke gronden voor ontslag zijn slechte bedrijfseconomische omstandigheden, langdurig ziekteverzuim en disfunctioneren. De kantonrechter hanteert de regels zoals beschreven in het Burgerlijk Wetboek. Hij ontbindt de arbeidsovereenkomst als er een gewichtige reden bestaat. Dit kan zijn een dringende reden, zoals bij een ontslag op staande voet, of een verandering van omstandigheden, zoals bijvoorbeeld slechte bedrijfseconomische omstandigheden, langdurige arbeidsongeschiktheid, of een verstoorde arbeidsverhouding. Een belangrijk verschil tussen het UWV WERKbedrijf en de kantonrechter is dat het UWV WERKbedrijf de werkgever niet veroordeelt tot het betalen van een ontslagvergoeding. De kantonrechter mag dit wel.

$\mathrm{Na}$ publicatie van de studies "Regulation or deregulation of the labour market. Policy regimes for the recruitment and dismissal of employees in industrialized countries" van Michael Emerson (1988), "Job security provisions and employment" van Ed Lazear (1990), en "Job security, employment and wages" van Guiseppe Bertola (1990) ontstaat er een grote interesse bij beleidsmakers om de mate van rigiditeit van ontslagbescherming te bepalen. Sindsdien berekent de OECD voor een groot aantal van haar lidstaten een Employment Protection Legislation index (EPL-index). Volgens deze index is de Nederlandse arbeidsmarkt voor werknemers met vaste contracten strikt, alleen het Portugese en het Duitse ontslagbeleid wordt gekarakteriseerd als strikter.

Een veelgehoorde theorie is dat een strikt ontslagbeleid geassocieerd is met het falen van West-Europese arbeidsmarkten zich aan te passen aan veranderende economische omstandigheden (OECD, 1994; Bertola and Rogerson, 1996; Bentolila and Bertola, 1990). Als een reactie op deze theorie hebben verschillende Europese instituten hun lidstaten geadviseerd hun ontslagrecht te flexibiliseren (zie onder andere de OECD Jobs Study, 1994, p50). Als gevolg heeft

\footnotetext{
${ }^{239}$ Ander manieren om een arbeidscontract te beëindigen zijn op met wederzijds goedvinden, van rechtswege, tijdens en bij eindiging van de proeftijd en op staande voet. Deze manieren vallen buiten het bereik van dit proefschrift.
} 
Nederland een aantal malen geprobeerd het ontslagsysteem drastisch te wijzigen. ${ }^{240}$ Eén van deze meeste recente pogingen, door toenmalig Minister van Sociale Zaken en Werkgelegenheid Piet Hein Donner, was de aanleiding tot het schrijven van dit proefschrift. In een adviesaanvraag, gedateerd op 3 juli 2007, brengt Minister Donner de Stichting van de Arbeid op de hoogte van de regeringsplannen voor de wijziging van het ontslagstelsel. Eén van de belangrijkste onderdelen van het voorstel was de overgang naar een enkelvoudige regeling in het Burgerlijk Wetboek. Volgens de minister leidt het relatief strikte Nederlandse ontslagrecht tot een slecht functionerende arbeidsmarkt. Een meer flexibel systeem waarin ontslagkosten lager zijn zou moeten leiden tot een verhoogde arbeidsparticipatie, vooral onder oudere werknemers, jongere werknemers en vrouwen (AV/IR/2007/23064). De plannen van de minister worden uiteindelijk, na het instellen van de Commissie Bakker in december 2007, van tafel geschoven. Wij waren toen van mening, en dat zijn we nog steeds, dat de discussie over de wijziging van het Nederlandse ontslagrecht is gebaseerd op ongetoetste aannames. De te verwachte uitwerking van voorgestelde wijzigingen zijn niet of nauwelijks te verifiëren. Studies over het effect van ontslagrecht op de werking van de arbeidsmarkt leveren geen eenduidige resultaten, mede doordat de manier waarop de mate van ontslagbescherming gemeten wordt verschilt per studie. Ook zijn de situaties die worden onderzocht nogal verschillend van elkaar. Bovendien is de optie om te kiezen voor één van beide routes op zichzelf al een vorm van flexibiliteit. Hierover horen we echter zelden of nooit iets terug in de debatten over de sociale innovatie van de arbeidsmarkt. We horen sowieso weinig over de positieve aspecten van het Nederlandse ontslagrecht. De indeling van dit proefschrift is als volgt:

Hoofdstuk 2 start met een beschrijving van het Nederlandse ontslagsysteem. Allereerst beschrijft het hoofdstuk de regels voor ontslag via het UWV en de kantonrechter. Daarnaast geeft Hoofdstuk 2 een gedetailleerde beschrijving van de geschiedenis van het Nederlandse ontslagrecht. Een belangrijk vertrekpunt voor de ontwikkelingen in het Nederlandse systeem is de invoering van het Burgerlijk Wetboek (BW) in 1838. Ook al was er van ontslagrecht nog geen sprake, wel bevatte dit wetboek enkele wetsartikelen betreffende de 'huur van dienstboden en werklieden'. Regels inzake de arbeidsrelatie waren opgenomen in het algemene overeenkomstenrecht waarin contractsvrijheid aan de basis stond. Deze contractsvrijheid hield in dat werknemers niet langer - in tegenstelling tot het eerdere gildensysteem - gebonden waren aan hun werkgevers. De Wet op de Arbeidsovereenkomst van 1907 introduceerde de eerste beschermende ontslagbepalingen ten gunste van de werknemer. Een belangrijk element in deze wet was dat een contract voor onbepaalde tijd niet mocht worden beëindigd zonder inachtneming van een opzegtermijn. Door de invoering van artikel 1639 w kreeg de rechter de bevoegdheid een arbeidsovereenkomst te ontbinden. Dit kon alleen indien voor ontbinding een gewichtige reden bestond. Het Nederlandse ontslagrecht bleef op hoofdlijnen ongewijzigd totdat het Duitse bewind in 1940 het Eerste Uitvoeringsbesluit uitvaardigde. Dit besluit bevatte een ontslagverbod. Als gevolg daarvan konden werkgevers hun werknemers niet ontslaan zonder voorafgaande toestemming van de toenmalige Arbeidsinspectie. Voor ontslag was een redelijke grond noodzakelijk en toestemming werd alleen gegeven als het ontslag een toetsing op redelijkheid kon doorstaan. Na de oorlog werden de Duitse maatregelen door de Nederlandse regering gecontinueerd in het Buitengewoon Besluit Arbeidsverhoudingen (BBA) 1945. De rol van de Arbeidsinspectie werd overgenomen door het Gewestelijke Arbeidsbureau

${ }^{240}$ Deze pogingen zijn overigens gedaan sinds het begin het ontstaan van het duale ontslagstelsel in 1945. 
en later door het UWV WERKbedrijf. Echter, artikel 1639w in het Burgerlijk Wetboek bepaalde dat ook de rechter de bevoegdheid had een arbeidsovereenkomst te ontbinden. Er bestonden nu dus twee wettelijke wegen om een arbeidscontract te beëindigen. Het duale ontslagstelsel was een feit. Hoofdstuk 2 sluit af met een internationale vergelijking op basis van de OESO index ${ }^{241}$.

Hoofdstuk 3 beschrijft hoe wij een unieke dataset ${ }^{242}$ hebben verzameld met informatie over 2.257 ontbindingsprocedures bij de kantonrechter voor de periode 2003-2009 en 1.134 ontslagprocedures bij het UWV voor de periode 2006-2009. Dit was geen eenvoudige taak omdat niet alle benodigde informatie digitaal is opgeslagen. Als gevolg hebben wij een groot deel van deze informatie uit papieren ontslagdossiers overgenomen en verwerkt.

Hoofdstuk 4 vervolgt met een vergelijkende analyse van ontslagkosten bij het UWV WERKbedrijf en de kantonrechter. Dit hoofdstuk toont aan dat het ontslag van een gemiddelde werknemer 18,5 duizend euro kost. Voor werkgevers die de kantonrechter-route volgden is dit 31 duizend euro. Werkgevers die UWV-route volgden werden geconfronteerd met een 7,5 duizend euro aan kosten. Eerder schatten Hassink Reitsma en Roorda (1998) en Knegt en Tros (2007) de kosten van ontslag via beide routes. Het overzicht van kosten in Hoofdstuk 4 geeft een meer recentelijk beeld. Bovendien rapporteren wij kosten zoals genoteerd in de daadwerkelijke ontslagdossiers van het UWV en de kantonrechter. De studies van Hassink e.a. en Knegt en Tros maken gebruik van vragenlijsten. Onze methode leidt tot een meer precieze inschatting.

Hoofdstuk 5 presenteert de stelling dat de Nederlandse arbeidsmarkt bewijst dat de aanname dat een rigide ontslagrecht leidt tot een slecht functionerende arbeidsmarkt niet per definitie juist is. In vergelijking met de andere EU15 landen is de Nederlandse arbeidsmarkt voor werknemers met vaste contracten strikt. Alleen Duitsland en Portugal scoren hoger op basis van de OESO index. Internationaal gezien scoort Nederland echter erg goed op verschillende arbeidsmarktindicatoren: Nederland kent de laagste werkloosheid van alle EU15 landen, op Oostenrijk na. Op het gebied van arbeidsparticipatie neemt Nederland de eerste plaats in en ook op productiviteit scoort Nederland ruim boven het gemiddelde. Vervolgens laat Hoofdstuk 5 zien dat grote werkgevers vaker naar de kantonrechter stappen dan kleinere werkgevers. Bovendien behandelt de kantonrechter met name ontslagen waaraan het disfunctioneren van de werknemer ten grondslag ligt. Het UWV beoordeelt vooral zaken met een economische achtergrond en langdurig zieken.

We vervolgen Hoofdstuk 5 met de stelling dat het Nederlandse systeem kan worden getypeerd als een systeem waarin werkgevers die een arbeidsovereenkomst vanwege economische noodzaak willen beëindigen kunnen worden gevrijwaard van het betalen van een ontslagvergoeding. Deze vergoedingsvrijwaring kan worden geïnterpreteerd als een lastenverlichting voor de werkgever in perioden van economische malaise die maatschappelijk wordt gefinancierd door de Nederlandse belastingbetaler. We zien dit als een efficiënt georganiseerde vorm van solidariteit. Preventieve toetsing en de vergoedingsvrijwaring van het UWV zijn belangrijke instrumenten van het Nederlandse arbeidsmarktbeleid. Het voorkomt dat werkgevers op grote schaal misbruik maken van deze vorm van solidariteit en ontslag niet

\footnotetext{
${ }^{241}$ Belangrijke bronnen die zijn gebruikt voor de beschrijving van de geschiedenis van het Nederlandse ontslagrecht in Hoofdstuk 2 zijn Naber (1981), Nyfer (2000), Heerma Van Voss (1992), Pennings (2007), CPB (2006), Loonstra and Zondag (2008) and Van Drongelen, and Van Rijs, (2008).

${ }^{242}$ Met dank aan Tamara Dekker en Eva Feron.
} 
willekeurig wordt. In een theoretisch model van optimaal conjunctureel ontslagbeleid tonen wij aan dat de verwachte kosten van de vergoedingsvrijwaring lager zijn dan de kosten van werkloosheidsuitkeringen. Bovendien voorkomt het 'UWV-instrument' moreel riskant gedrag van werkgevers. Het UWV biedt werkgevers in economische problemen de mogelijkheid hun werknemers op een rechtmatige manier te ontslaan, zonder dat zij daarvoor een vergoeding hoeven te betalen. Voor onredelijke ontslagen wordt geen vergunning afgegeven. Op deze manier voorkomt het Nederlandse systeem vooral in economisch barre tijden dat de kosten die voortkomen uit onredelijke ontslagen worden afgewenteld op de belastingbetaler. Dit argument is niet nieuw. Integendeel. Bij decreet van de regering in ballingschap werd direct na afloop van de Tweede Wereldoorlog juist dit argument gebruikt om het duale stelsel te handhaven ter bevordering van het productief en concurrerend vermogen van de Nederlandse economie.

Hoofdstuk 6 laat zien dat de kans dat een werkgever zonder redelijke grond een UWV ontslagprocedure start, toeneemt bij stijgende werkloosheidspercentages. De kans echter dat het UWV een ontslagvergunning afgeeft, neemt af bij stijgende werkloosheidspercentages. Dit betekent dat de preventieve toetsing onredelijke ontslagen een halt toe brengt en met name in tijden van economische recessies extra kosten van onredelijke ontslagen voorkomt. We vinden geen bewijs dat de kwaliteit van de ontbindingsverzoeken bij de kantonrechter samenhangt met werkloosheid.

In Hoofdstuk 7 presenteren wij de op 18 juni 2012 door Minister Kamp geformuleerde plannen met betrekking tot de hervorming van het ontslagrecht en de WerkeloosheidsWet (WW). Deze plannen zijn eerder vorm gegeven in het Lenteakkoord door de Kunduz partijen VVD, CDA, D66, GroenLinks en ChristenUnie. In het kort bevat het voorgestelde plan van Minister Kamp de volgende drie hoofdelementen ${ }^{243}$ :

1) Het duale ontslagstelsel wordt vervangen door een enkelvoudig (civielrechtelijk repressief) stelsel. De preventieve toetsing wordt afgeschaft. Er wordt een hoorprocedure ingevoerd tijdens welke de werknemer in de gelegenheid wordt gesteld te reageren op het voorgenomen ontslag.

2) De ontslagvergoeding neemt plaats voor een transitiebudget dat moet worden ingezet om de transitie naar een andere baan vergemakkelijken (bijv. scholing). Dit transitiebudget is gelijk aan een kwart maandsalaris per dienstjaar met een maximum van 6 maanden en is voor iedereen, vaste en tijdelijke contracten.

3) Werkgevers gaan betalen voor ten hoogste de eerste 6 maanden van de werkeloosheidsuitkering.

Wij uiten onze bezwaren tegen de plannen. In een kostenberekening laten wij zien dat de voorgestelde maatregelen niet zullen leiden tot een afname in kosten voor werkgevers. Ontslag zal voor met name kleinere werkgevers duurder worden. Ook leidt een repressieve toetsing tot onzekerheid. Mocht een ontslagen werknemer besluiten het ontslag aan te vechten bij de rechter, dan kunnen werkgevers lange tijd na het ontslag worden geconfronteerd met hoge kosten. De repressieve toetsing leidt ook voor werknemers tot veel onzekerheid omdat ook zij pas na een langdurige periode van onzekerheid uitsluitsel van de rechter krijgen. Het is aannemelijk dat veel werknemers besluiten af te zien van een rechterlijke procedure om het

\footnotetext{
${ }^{243}$ Uit Hoofdlijnen aanpassing ontslagrecht en ww van (demissionair) Minister Kamp (SZW).
} 
ontslag aan te vechten. Als gevolg van deze beslissing komen sommigen van hen dus onrechtmatig op straat te $\operatorname{staan}^{244}$.

De publicatie van het Regeerakkoord op 29 oktober 2012 heeft geleid tot Hoofdstuk 8. Het is duidelijk dat de plannen zoals opgesteld door Minister Kamp, waarbij de PvdA niet betrokken was, meer drastische wijzigingen voorstelden. Wij zijn van mening dat het voorstel van de nieuwe regering, om preventieve toetsing te behouden en ondernemingen van het betalen van een transitievergoeding bij economische noodzaak te vrijwaren, een aanzienlijke verbetering is ten opzichte van het ondoordachte compromis van het Lenteakkoord. Naast de positieve aspecten van het regeerakkoord plaatsen wij ook enkele vraagtekens bij de nieuwe plannen. Zo gaan de kosten voor werkgevers die oorspronkelijk de UWV-route volgden omhoog en is het aannemelijk dat werknemers vaker hun ontslag achteraf bij de kantonrechter zullen aanvechten. Dergelijke maatregelen leiden niet tot de sociale innovatie die noodzakelijk is voor de modernisering van de arbeidsmarkt.

De algemene conclusie van deze bijdrage is dat wij het onverstandig achten de preventieve toetsing en de dualiteit van het systeem af te schaffen. De preventieve toetsing brengt onredelijke ontslagen een halt toe. Bovendien voorkomt preventieve toetsing van het UWV en de daarbij horende vergoedingsvrijwaring "moreel riskant" gedrag van werkgevers. De verwachte kosten van deze vergoedingsvrijwaring zijn lager dan de kosten van werkloosheidsuitkeringen. Het duale aspect van het Nederlandse systeem leidt tot keuzevrijheid, wat op zichzelf al een vorm van flexibiliteit is. Bovendien kent het systeem een sterke specialisatie: het UWV WERKbedrijf beslist met name over ontslag door langdurige ziekte en economische malaise. De kantonrechter wordt met name ingezet voor arbeidsconflicten. Beide specialisaties kennen een lange traditie met veel verworven kennis en ervaring. Afschaffing van het duale systeem is derhalve inefficiënt.

Modernisering van de werking van de Nederlandse arbeidsmarkt is wenselijk. Er schuilt echter een gevaar achter harmonisering met het Europese model: De werking van het Nederlandse stelsel zal lijden onder een aanpassing die gebaseerd is op meningen in plaats van op wetenschappelijk bewijs.

\footnotetext{
${ }^{244}$ In geval dat het ontslag niet terecht is.
} 


\section{REFERENCES}

Acemoglu, D., \& Angrist, J.D. (2001). “Consequences of employment protection? The case of the Americans with disabilities act." Journal of Political Economy 109 (5), pp. 915-957.

Acemoglu, D., \& Shimer R. (1999). "Efficient Unemployment Insurance." Journal of Political Economy 107 (5), pp. 893-928.

Addison, J.T., \& Grosso, J. (1996). "Job security provisions and employment: Revised estimates." Industrial Relations 35 (4), pp. 585-603.

Addison, J.T., \& Teixeira, P. (2003). "The Economics of Employment Protection." Journal of Labor Research XXIV (I), pp. 85-129.

Addison, J.T.,Teixeira, P., \& Grosso, J. (2000). "The effect of dismissals protection on employment: More on a vexed theme." Southern Economic Journal 67 (1), pp. 105-122.

Akerlof, G.A., \& Yellen, J.L. (1985). "A Near Rational Model of the Business Cycle with Wage and Price Inertia." Quarterly Journal of Economics 100 (Supplement), pp. 823-38.

Autor, D.H., Donohue III, J.J., \& Schwab, S. J. (2006). "The costs of wrongful discharge laws." Review of Economics and Statistics 88, pp. 211-331.

Autor, D.H., Kerr, R, W., \& Kugler, A.D. (2007). "Do Employment Protections Reduce Productivity? Evidence from US states" The economic journal 117 (521), pp. F189-F217.

Ball, L. (1996). “Disinflation and the NAIRU”, NBER Working Paper, 5520.

Bartelsman, E., Gautier P., \& De Wind, J "Minder rigide ontslagbescherming maakt Nederland innovatiever en productiever", Me Judice, 18 juni 2012.

Bartelsman, E., Gautier P., \& De Wind, J. (2010). “Employment Protection, Technology Choice, and Worker Allocation," Tinbergen Institute discussion paper.

Bartelsman, E., Gautier P., \& De Wind, J. (2011). "Employment Protection, Technology Choice", VoxEU.

Bauer, T.K., Bender, S., \& Bonin, H. (2007). "Dismissal protection and worker flows in small establishments." Economica 74, pp. 804-819. 
Belot, M., \& Boone,J., \& Van Ours, J.C. (2007). "Welfare-Improving Employment Protection." Economica 74, pp. 381-396.

Belot M., \& Van Ours, J.C. (2004). "Does the recent success of some OECD countries in lowering their unemployment rates lie in the clever design of their labor market reforms?" Oxford Economic Papers 56, pp. 621-42.

Bender, S., Dustmann, C., Margolis, D., \& Meghir, C. (2002). "Worker Displacement in France and Germany." In Losing Work, Moving On: International Perspectives on Worker Displacement, Peter J. Kuhn, ed. Kalamazoo, MI: W.E. Upjohn Institute for Employment Research, pp. 375-470.

Bentolila, S., \& Bertola G. (1990). "Firing costs and labour demand: How bad is eurosclerosis?" Review of economic studies 57 (3), pp. 381-402.

Bertola, G. (1990). "Job security, employment and wages." European Economic Review 34(4), pp. 851-79.

Bertola, G., \& Rogerson, G. (1996). "Institutions and Labor Reallocation", NBER Working Paper, 5828.

Besley, T., \& Case, A. (1995). "Does electoral accountability affect economic policy choices? Evidence from gubernatorial term limits" The Quarterly Journal of Economics 110(3), pp. 769798.

Boeri, T., \& Jimeno J.F. (2005). "The effects of employment protection: Learning from variable enforcement." European Economic Review 49, pp. 2057-2077.

Blanchard, O., \& Portugal, P. (2001). "What Hides Behind the Unemployment Rate: Comparing Portuguese and U.S.Labor Markets." American Economic Review 91 (1), pp. 187-207.

CPB document no. 135. EPL lessons from theoretical and empirical studies for the Dutch case. (2006).

Davis, S.J., \& Haltiwanger, J. (1992). "Gross Job Creation, Gross Job Destruction, and Employment Reallocation." Quarterly Journal of Economics 107 (3), pp. 819-63.

Dekker, R., \& Kleinknecht, A. (2008). 'Flexibel werk schaadt groei arbeidsproductiviteit', ESB 2008, nr. 4533.

DeLeire, T. (2000). "The Wage and Employment Effects of the Americans with Disabilities Act." The Journal of Human Resources 35 (4), pp. 693-715.

Delsen, L. (2002). Exit poldermodel? Greenwood Publishing Group.Netherlands." International Economic Journal 19 (2), pp. 169-196. 


\section{REFERENCES}

Di Tella, R., \& MacCulloch, R. (2005). "The consequences of labor market flexibility: Panel evidence based on survey data." European Economic Review 49 (5), pp. 1225-1259.

Drongelen, J. van. (1998) Teksten en toelichting op de Wet flexibiliteit en zekerheid. Koninklijke Vermande. Lelystad.

Drongelen, J. van., \& Rijs, A.D.M. van. (2008). De ontslagpraktijk van de CWI. Kluwer, Deventer.

Drazen, A., Hamermesh, D.S., \& Obst, N.P., (1984). "The Variable Employment Elasticity Hypothesis: Theory and Evidence." Research in Labor Economics 6, pp. 287-309.

Elling, R.C. (1982). "Ideological Change in the U. S. Senate: Time and Electoral Responsiveness." Legislative Studies Quarterly 7 (1), pp. 75-92.

Emerson, M. (1988). "Regulation or deregulation of the labour market: policy regimes for the recruitment and dismissal of employees in the industrialized countries." European Economic Review 32 (4), pp. 775-817.

European Commission (2003) http://eur-lex.europa.eu

Freeman, R. B. (2008a). "War of the Models: Which Labour Market Institutions for the 21st Century?" Labour Economics 5 (1), pp. 1-24.

Freeman, R. B. (2008b). "Labour Market Institutions Around the World." CEP Discussion Paper No 844 .

Garibaldi, P., \& Violante, G.L. (2005). "The Employment Effects of Severance Payments with Wage Rigidities." Economic Journal 115, pp.779-832.

Gomez-Salvador,R., \& Messina, J., \& Vallanti, G. (2004). "Gross job flows and institutions in Europe" Labour Economics 11, pp. 469-485.

Grinten, van der, W.C.L. (2005). Arbeidsovereenkomstenrecht. Kluwer, Deventer.

Grubb, D., \& Wells, W. (1993). "Employment regulation and patterns of work in EC countries." OECD Economic Studies 21, pp. 7-58. OECD. Paris.

Hall, M. (1992). "Electoral politics and strategic voting in state supreme courts." The Journal of Politics 54 (2), pp. 427-446.

Hamermesh, D.S. (1996). Labor Demand. Princeton University Press.

Hassink, W.H.J., Reitsma, A.M., \& Roorda W.B. (1998). “Gedwongen ontslag via kantonrechter of RDA; een economische analyse." SMA 10 
Heerma Van Voss, G. (1992). Ontslagrecht in Nederland en Japan. Kluwer, Deventer.

Heijden, P.F. van der. (1998). Compendium bijzondere overeenkomsten. Kluwer, Deventer.

Huber, G.A., \& Gordon, S.C. (2004). "Accountability and coercion: Is justice blind when it runs for office?" American Journal of Political Science 48 (2), pp. 247-263.

Ichino, A., Polo, M., \& Rettore, E. (2003). “Are judges biased by labor market conditions?" European Economic Review 47, pp. 913-944.

International Labour Office (ILO) (2005). “Employment Analysis and Research Unit Employment Strategy Department. Protected mobility for employment and decent work: Labour market security in a globalised world." Employment Strategy Papers (2005)

Kaldor, N. (1936) "Wage Subsidies as a Remedy for Unemployment." Journal of Political Economy 44 (6), pp. 721-742.

Keirse, A.L.M. (2003). Schadebeperkingsplicht. Over eigen schuld aan de omvang van de schade. Kluwer, Deventer.

Knegt, R. \& Tros, F.H. (2007). Ontslagkosten van werkgevers. Hugo Sinzheimer Instituut. Universiteit van Amsterdam.

Kleinknecht, A., Naastepad, R., \& Storm, S. (2012). “Het nut van ontslagbescherming.” S\&D 3.

Kugler, A., \& Pica, G. (2008). "Effects of employment protection on worker and job flows: Evidence from the 1990 Italian reform." Labour Economics 15 (1), pp 78-95.

Landais, C., Michaillat, P., \& Saez, E. (2010). "Optimal Unemployment Insurance over the Business Cycle." NBER Working Paper 16526.

Lazear, E.P. (1990). "Job security provisions and employment." Quarterly Journal of Economics 105 (3), pp. 699-726.

Loonstra, C.J., \& Zondag, W.A. Arbeidsrechtelijke themata. Derde druk (2008). Boom Juridische uitgevers, Den Haag.

Marinescu, I. (2011). "Are Judges Sensitive to Economic Conditions - Evidence from UK Employment Tribunals." Industrial and Labor Relations Review 64 (4), pp. 673-298.

Michaillat, P. (2012). “Do Matching Frictions Explain Unemployment?: Not in Bad Times." American Economic Review (In Press).

Mincer, J. (1958). "Investment In Human Capital and the Personal Income Distribution," Journal of Political Economy 66, pp. 281-302. 
Mortensen, D., \& Pissarides, C. (1994). "Job Creation and Job Destruction in the Theory of Unemployment." Review of Economic Studies 61, pp. 397-415.

Naber, H. Van een preventief ontslagverbod terug naar een repressief ontslagrecht? (1981). Kluwer, Deventer.

Nickell, S. (1997) "Unemployment and Labor Market Rigidities: Europe versus North America." The Journal of Economic Perspectives 11 (3), pp. 55-74.

Nyfer. Bescherming en Economische Efficiëntie: Een alternatief ontslagstelsel. (2000). Nyfer, Breukelen.

NOS. Akkoord Donner met FNV en VNO-NCW. (2008) www.nos.nl. Retrieved from the World Wide Web, December 9th, 2008.

NRC Handelsblad. Donner krijgt groen licht plannen ontslagrecht. (2007). www.nrc.nl. Retrieved from the World Wide Web, December 8th, 2008.

OECD (1994). THE OECD JOBS STUDY 1994, Paris

OECD (1999). OECD EMPLOYMENT OUTLOOK 2004, Paris

OECD (2004). OECD EMPLOYMENT OUTLOOK 2004, Paris

Oyer, P., \& Schaefer. S. (2000). "Layoffs and Litigation." The RAND Journal of Economics 31 (2), pp. 345-358.

Peeters, S.S.M. (2006). Verdund sociaal recht: onderscheid naar ondernemingsomvang bij medezeggenschap, ziekte en ontslag. Kluwer, Deventer.

Pennings, F.J.L. Nederlands arbeidsrecht in een internationale context. (2007). Kluwer, Deventer.

Pfann, G.A. (2006). "Downsizing and heterogeneous firing costs." The Review of Economics and Statistics 88 (1), pp. 158-170.

Pfann, G.A., \& Verspagen, B. (1989). "The structure of adjustment costs for labour in the Dutch manufacturing sector.” Economic letters 29 (4), pp. 365-371.

Pissarides, C. (2001). “Employment Protection.” Labour Economics 8 (2), pp.131-159.

Ramón Gómez-Salvador, R., Messina, J., \& Vallanti, G. (2004). “Gross job flows and institutions in Europe." Labour Economics 11 (4), pp. 469-485. 
Research voor Beleid. (2001). Ontslagroutes naar de ww. In opdracht van het Ministerie van Sociale Zaken en Werkgelegenheid. Leiden.

Scarpetta. S. (1996). "Assessing the role of labour market policies and institutional settings on unemployment: an cross-country study." OECD Economic Studies 26.

Siegelman, P., \& Donohue III, J.J. (1995). "The selection of employment discrimination disputes for litigation: using business cycle effects to test the Priest-Klein hypothesis." Journal of Legal Studies XXIV, pp. 427-462.

Thomas, M. (1985). "Election Proximity and Senatorial Roll Call Voting." American Journal of Political Science 29 (1), pp.96-111.

Trommel, W.A., \& Veen, R. van der. (1999). De herverdeelde samenleving. Amsterdam University Press.

UWV. UWV WERKbedrijf Arbeidsmarktprognose 2011-2012. Met een doorkijk naar 2016. (2011) Amsterdam.

Vergeer, R., \& Kleinknecht, A. (2010). " The impact of labor market regulation on productivity: a panel data analysis of 19 OECD countries (1960-2004)." Journal of Post Keynesian Economics 33 (2), pp. 371-408.

Wright, G. C., \& Berkman, M.B. (1986). "Candidates and Policy in United States Senate Elections" The American Political Science Review 80 (2), pp. 567-588.

Yellen, Janet L. (1984). "Wage Models of Unemployment", American Economic Review 74 (2) Papers and Proceedings, pp. 200-205. 


\section{APPENDICES}

Appendix A: Rankings PES data, from lowest to highest percentage.

Source PES: national data base (ARCOS), 2008.

Table A1 Rankings: Dismissal reason.

\begin{tabular}{|c|c|c|c|c|c|c|c|}
\hline & $\mathbf{n}$ & Economical & $\%$ of $n$ & & $\mathrm{n}$ & $\begin{array}{l}\text { Dysfunctional } \\
\text { behavior }\end{array}$ & $\%$ of $n$ \\
\hline Amersfoort & 2,171 & 1,242 & 57.21 & Eindhoven & 4,582 & 77 & 1.68 \\
\hline Haarlem & 4,351 & 2,653 & 60.97 & Maastricht & 1,419 & 27 & 1.90 \\
\hline Den Haag & 2,670 & 1,631 & 61.09 & Hengelo & 1,633 & 33 & 2.02 \\
\hline Maastricht & 1,419 & 873 & 61.52 & Haarlem & 4,351 & 103 & 2.37 \\
\hline Rotterdam & 2,432 & 1,545 & 63.53 & Amersfoort & 2,171 & 52 & 2.40 \\
\hline Breda & 1,828 & 1,212 & 66.30 & Rotterdam & 2,432 & 59 & 2.43 \\
\hline Groningen & 1,378 & 939 & 68.14 & Leeuwarden & 707 & 18 & 2.55 \\
\hline Leeuwarden & 707 & 502 & 71.00 & Den Haag & 2,670 & 72 & 2.70 \\
\hline Eindhoven & 4,582 & 3,277 & 71.52 & Arnhem & 3,660 & 104 & 2.84 \\
\hline Hengelo & 1,633 & 1,170 & 71.65 & Groningen & 1,378 & 40 & 2.90 \\
\hline Arnhem & 3,660 & 2,686 & 73.39 & Breda & 1,828 & 60 & 3.28 \\
\hline \multirow[t]{2}{*}{ Total } & 26,833 & 17,730 & 66.08 & Total & 26,833 & 645 & 2.40 \\
\hline & $\mathrm{n}$ & $\begin{array}{l}\text { Disturbed } \\
\text { relationship }\end{array}$ & $\%$ of $n$ & & $\mathrm{n}$ & $\begin{array}{l}\text { Reproachable } \\
\text { behavior }\end{array}$ & $\%$ of $n$ \\
\hline Leeuwarden & 707 & 6 & 0.85 & Maastricht & 1,419 & 39 & 2.75 \\
\hline Eindhoven & 4,582 & 45 & 0.98 & Breda & 1,828 & 53 & 2.90 \\
\hline Maastricht & 1,419 & 17 & 1.20 & Arnhem & 3,660 & 123 & 3.36 \\
\hline Arnhem & 3,660 & 45 & 1.23 & Groningen & 1,378 & 47 & 3.41 \\
\hline Den Haag & 2,670 & 34 & 1.27 & Leeuwarden & 707 & 26 & 3.68 \\
\hline Groningen & 1,378 & 18 & 1.31 & Hengelo & 1,633 & 64 & 3.92 \\
\hline Hengelo & 1,633 & 22 & 1.35 & Eindhoven & 4,582 & 187 & 4.08 \\
\hline Haarlem & 4,351 & 62 & 1.42 & Amersfoort & 2,171 & 123 & 5.67 \\
\hline Rotterdam & 2,432 & 36 & 1.48 & Den Haag & 2,670 & 178 & 6.67 \\
\hline Breda & 1,828 & 29 & 1.59 & Rotterdam & 2,432 & 164 & 6.74 \\
\hline Amersfoort & 2,171 & 40 & 1.84 & Haarlem & 4,351 & 340 & 7.81 \\
\hline \multirow[t]{2}{*}{ Total } & 26,833 & 354 & 1.32 & Total & 26,833 & 1,344 & 5.01 \\
\hline & $\mathbf{n}$ & Frequent illness & $\%$ of $n$ & & $n$ & Prolonged illness & $\%$ of $n$ \\
\hline Hengelo & 1,633 & 0 & 0.00 & Arnhem & 3,660 & 660 & 18.03 \\
\hline Leeuwarden & 707 & 0 & 0.00 & Hengelo & 1,633 & 316 & 19.35 \\
\hline Groningen & 1,378 & 1 & 0.07 & Eindhoven & 4,582 & 921 & 20.10 \\
\hline Arnhem & 3,660 & 4 & 0.11 & Leeuwarden & 707 & 144 & 20.37 \\
\hline Amersfoort & 2,171 & 3 & 0.14 & Groningen & 1,378 & 311 & 22.57 \\
\hline Haarlem & 4,351 & 7 & 0.16 & Rotterdam & 2,432 & 560 & 23.03 \\
\hline Rotterdam & 2,432 & 5 & 0.21 & Haarlem & 4,351 & 1,040 & 23.90 \\
\hline Eindhoven & 4,582 & 10 & 0.22 & Breda & 1,828 & 442 & 24.18 \\
\hline Breda & 1,828 & 4 & 0.22 & Den Haag & 2,670 & 694 & 25.99 \\
\hline Den Haag & 2,670 & 7 & 0.26 & Amersfoort & 2,171 & 639 & 29.43 \\
\hline Maastricht & 1,419 & 5 & 0.35 & Maastricht & 1,419 & 437 & 30.80 \\
\hline Total & 26,833 & 46 & 0.17 & Total & 26,833 & 6,166 & 22.98 \\
\hline
\end{tabular}


Table A1 continued.

\begin{tabular}{lccc}
\hline & $\mathbf{n}$ & $\begin{array}{c}\text { Measure } \\
\text { reintegration }\end{array}$ & \% of $\mathbf{~}$ \\
\hline Leeuwarden & 707 & 1 & 0.14 \\
Eindhoven & 4,582 & 8 & 0.17 \\
Den Haag & 2,670 & 10 & 0.37 \\
Maastricht & 1,419 & 6 & 0.42 \\
Hengelo & 1,633 & 7 & 0.43 \\
Arnhem & 3,660 & 16 & 0.44 \\
Rotterdam & 2,432 & 16 & 0.66 \\
Groningen & 1,378 & 14 & 1.02 \\
Breda & 1,828 & 23 & 1.26 \\
Amersfoort & 2,171 & 38 & 1.75 \\
Haarlem & 4,351 & 98 & 2.25 \\
Total & 26,833 & 237 & 0.88 \\
\hline
\end{tabular}

Table A2 Rankings: Individual or collective economical dismissal.

\begin{tabular}{|c|c|c|c|c|c|c|c|}
\hline & $\mathbf{n}$ & $\begin{array}{l}\text { Economical: } \\
\text { Individual }\end{array}$ & $\%$ of $n$ & & $\mathbf{N}$ & $\begin{array}{c}\text { Economical: } \\
\text { Collective }\end{array}$ & $\%$ of $n$ \\
\hline Den Haag & 2,670 & 1,058 & 39.63 & Groningen & 1378 & 70 & 5.08 \\
\hline Arnhem & 3,660 & 1,524 & 41.64 & Amersfoort & 2171 & 126 & 5.80 \\
\hline Breda & 1,828 & 851 & 46.55 & Leeuwarden & 707 & 52 & 7.36 \\
\hline Eindhoven & 4,583 & 2,190 & 47.79 & Maastricht & 1419 & 105 & 7.40 \\
\hline Rotterdam & 2,432 & 1,163 & 47.82 & Haarlem & 4352 & 449 & 10.32 \\
\hline Haarlem & 4,352 & 2,204 & 50.64 & Rotterdam & 2432 & 382 & 15.71 \\
\hline Amersfoort & 2,171 & 1,116 & 51.40 & Hengelo & 1633 & 279 & 17.09 \\
\hline Maastricht & 1,419 & 768 & 54.12 & Breda & 1828 & 361 & 19.75 \\
\hline Hengelo & 1,633 & 891 & 54.56 & Den Haag & 2670 & 573 & 21.46 \\
\hline Groningen & 1378 & 869 & 63.06 & Eindhoven & 4583 & 1087 & 23.72 \\
\hline Leeuwarden & 707 & 450 & 63.65 & Arnhem & 3660 & 1162 & 31.75 \\
\hline Total & 26,833 & 13,084 & 48.76 & Total & 26833 & 4646 & 17.31 \\
\hline
\end{tabular}

Table A3 Rankings: Age categories.

\begin{tabular}{|c|c|c|c|c|c|c|c|}
\hline & n & $15-24$ & $\%$ of $n$ & & $\mathbf{n}$ & $25-44$ & $\%$ of $n$ \\
\hline astricht & 1,419 & 46 & 3.24 & Breda & 1,828 & 677 & 37.04 \\
\hline Leeuwarden & 707 & 23 & 3.25 & Rotterdam & 2,432 & 968 & 39.80 \\
\hline Arnhem & 3,660 & 133 & 3.63 & Eindhoven & 4,583 & 1,921 & 41.92 \\
\hline Rotterdam & 2,432 & 89 & 3.66 & Arnhem & 3,660 & 1,537 & 41.99 \\
\hline Eindhoven & 4,583 & 174 & 3.80 & Leeuwarden & 707 & 297 & 42.01 \\
\hline Den Haag & 2,670 & 105 & 3.93 & Hengelo & 1,633 & 702 & 42.99 \\
\hline Amersfoort & 2,171 & 106 & 4.88 & Amersfoort & 2,171 & 947 & 43.62 \\
\hline Breda & 1,828 & 90 & 4.92 & Den Haag & 2,670 & 1,169 & 43.78 \\
\hline Haarlem & 4,352 & 215 & 4.94 & Groningen & 1,378 & 616 & 44.70 \\
\hline Hengelo & 1,633 & 86 & 5.27 & Haarlem & 4,352 & 2,004 & 46.05 \\
\hline Groningen & 1,378 & 102 & 7.40 & Maastricht & 1,419 & 577 & 40.66 \\
\hline Total & 26,833 & 1,169 & 4.36 & Total & 26,833 & 11,415 & 42.54 \\
\hline
\end{tabular}




\section{APPENDICES}

Table A3 continued.

\begin{tabular}{lccc}
\hline & $\mathbf{n}$ & $\mathbf{4 5 - 6 4}$ & \% of $\mathbf{~}$ \\
\hline Groningen & 1,378 & 643 & 46.66 \\
Haarlem & 4,352 & 2,054 & 47.20 \\
Hengelo & 1,633 & 812 & 49.72 \\
Amersfoort & 2,171 & 1,087 & 50.07 \\
Den Haag & 2,670 & 1,356 & 50.79 \\
Leeuwarden & 707 & 371 & 52.48 \\
Eindhoven & 4,583 & 2,424 & 52.89 \\
Arnhem & 3,660 & 1,959 & 53.52 \\
Maastricht & 1,419 & 772 & 54.40 \\
Rotterdam & 2,432 & 1,340 & 55.10 \\
Breda & 1,828 & 1,029 & 56.29 \\
Total & 26,833 & 13,847 & 51.60 \\
\hline
\end{tabular}

\begin{tabular}{lccc}
\hline & $\mathbf{n}$ & $\mathbf{> 6 5}$ & \% of $\mathbf{~}$ \\
\hline Groningen & 1,378 & 5 & 0.36 \\
Leeuwarden & 707 & 3 & 0.42 \\
Arnhem & 3,660 & 16 & 0.44 \\
Eindhoven & 4,583 & 25 & 0.55 \\
Hengelo & 1,633 & 14 & 0.86 \\
Breda & 1,828 & 17 & 0.93 \\
Den Haag & 2,670 & 27 & 1.01 \\
Amersfoort & 2,171 & 22 & 1.01 \\
Haarlem & 4,352 & 46 & 1.06 \\
Rotterdam & 2,432 & 26 & 1.07 \\
Maastricht & 1,419 & 16 & 1.13 \\
Total & 26,833 & 217 & 0.81 \\
\hline
\end{tabular}

Table A4 Rankings: Industry.

\begin{tabular}{|c|c|c|c|c|c|c|c|}
\hline & $n$ & Industry & $\%$ of $n$ & & $\mathbf{n}$ & $\begin{array}{l}\text { Wholesale, } \\
\text { trade, etc. }\end{array}$ & $\%$ of $n$ \\
\hline Den Haag & 2,670 & 46 & 1.72 & Arnhem & 3,660 & 663 & 18.11 \\
\hline Rotterdam & 2,432 & 138 & 5.67 & Rotterdam & 2,432 & 472 & 19.41 \\
\hline Haarlem & 4,351 & 307 & 7.06 & Eindhoven & 4,582 & 989 & 21.58 \\
\hline Groningen & 1,378 & 101 & 7.33 & Den Haag & 2,670 & 580 & 21.72 \\
\hline Leeuwarden & 707 & 54 & 7.64 & Hengelo & 1,633 & 408 & 24.98 \\
\hline Amersfoort & 2,171 & 244 & 11.24 & Amersfoort & 2,171 & 557 & 25.66 \\
\hline Maastricht & 1,419 & 241 & 16.98 & Maastricht & 1,419 & 389 & 27.41 \\
\hline Breda & 1,828 & 450 & 24.62 & Haarlem & 4,351 & 1208 & 27.76 \\
\hline Arnhem & 3,660 & 993 & 27.13 & Leeuwarden & 707 & 201 & 28.43 \\
\hline Hengelo & 1,633 & 463 & 28.35 & Groningen & 1,378 & 405 & 29.39 \\
\hline Eindhoven & 4,582 & 1467 & 32.02 & Breda & 1,828 & 549 & 30.03 \\
\hline \multirow[t]{2}{*}{ Total } & 26,833 & 4504 & 16.79 & Total & 26,833 & 6421 & 23.93 \\
\hline & $\mathrm{n}$ & $\begin{array}{c}\text { Transport, storage, } \\
\text { etc }\end{array}$ & $\%$ of $n$ & & $\mathbf{n}$ & $\begin{array}{l}\text { Hotel and } \\
\text { catering }\end{array}$ & $\%$ of $n$ \\
\hline Groningen & 1,378 & 37 & 2.69 & Eindhoven & 4,582 & 59 & 1.29 \\
\hline Arnhem & 3,660 & 123 & 3.36 & Arnhem & 3,660 & 70 & 1.91 \\
\hline Amersfoort & 2,171 & 75 & 3.45 & Amersfoort & 2,171 & 51 & 2.35 \\
\hline Den Haag & 2,670 & 106 & 3.97 & Hengelo & 1,633 & 40 & 2.45 \\
\hline Haarlem & 4,351 & 195 & 4.48 & Maastricht & 1,419 & 40 & 2.82 \\
\hline Maastricht & 1,419 & 66 & 4.65 & Leeuwarden & 707 & 20 & 2.83 \\
\hline Hengelo & 1,633 & 86 & 5.27 & Groningen & 1,378 & 42 & 3.05 \\
\hline Eindhoven & 4,582 & 262 & 5.72 & Breda & 1,828 & 58 & 3.17 \\
\hline Breda & 1,828 & 114 & 6.24 & Rotterdam & 2,432 & 81 & 3.33 \\
\hline Rotterdam & 2,432 & 207 & 8.51 & Den Haag & 2,670 & 93 & 3.48 \\
\hline Leeuwarden & 707 & 96 & 13.58 & Haarlem & 4,351 & 252 & 5.79 \\
\hline Total & 26,833 & 1367 & 5.09 & Total & 26,833 & 806 & 3.00 \\
\hline
\end{tabular}


Table A4 continued.

\begin{tabular}{|c|c|c|c|c|c|c|c|}
\hline & $\mathrm{n}$ & $\begin{array}{c}\text { Commercial } \\
\text { services }\end{array}$ & $\%$ of $n$ & & $n$ & $\begin{array}{l}\text { Health and } \\
\text { wellness }\end{array}$ & $\%$ of $n$ \\
\hline Rotterdam & 2,432 & 268 & 11.02 & Leeuwarden & 707 & 60 & 8.49 \\
\hline Eindhoven & 4,582 & 597 & 13.03 & Groningen & 1,378 & 125 & 9.07 \\
\hline Breda & 1,828 & 248 & 13.57 & Breda & 1,828 & 178 & 9.74 \\
\hline Den Haag & 2,670 & 389 & 14.57 & Haarlem & 4,351 & 493 & 11.33 \\
\hline Arnhem & 3,660 & 551 & 15.05 & Eindhoven & 4,582 & 527 & 11.50 \\
\hline Leeuwarden & 707 & 108 & 15.28 & Hengelo & 1,633 & 189 & 11.57 \\
\hline Hengelo & 1,633 & 255 & 15.62 & Amersfoort & 2,171 & 273 & 12.57 \\
\hline Groningen & 1,378 & 227 & 16.47 & Maastricht & 1,419 & 215 & 15.15 \\
\hline Maastricht & 1,419 & 248 & 17.48 & Rotterdam & 2,432 & 388 & 15.95 \\
\hline Haarlem & 4,351 & 1013 & 23.28 & Den Haag & 2,670 & 466 & 17.45 \\
\hline Amersfoort & 2,171 & 633 & 29.16 & Arnhem & 3,660 & 687 & 18.77 \\
\hline \multirow[t]{2}{*}{ Total } & 26,833 & 4537 & 16.91 & Total & 26,833 & 3601 & 13.42 \\
\hline & $\mathrm{n}$ & $\begin{array}{l}\text { Culture and } \\
\text { Recreation }\end{array}$ & $\%$ of $n$ & & $n$ & Construction & $\%$ of $n$ \\
\hline Amersfoort & 2,171 & 49 & 2.26 & Haarlem & 4,351 & 135 & 3.10 \\
\hline Eindhoven & 4,582 & 145 & 3.16 & Den Haag & 2,670 & 119 & 4.46 \\
\hline Arnhem & 3,660 & 141 & 3.85 & Amersfoort & 2,171 & 100 & 4.61 \\
\hline Breda & 1,828 & 77 & 4.21 & Breda & 1,828 & 85 & 4.65 \\
\hline Leeuwarden & 707 & 31 & 4.38 & Hengelo & 1,633 & 78 & 4.78 \\
\hline Maastricht & 1,419 & 64 & 4.51 & Eindhoven & 4,582 & 231 & 5.04 \\
\hline Hengelo & 1,633 & 84 & 5.14 & Rotterdam & 2,432 & 133 & 5.47 \\
\hline Haarlem & 4,351 & 513 & 11.79 & Maastricht & 1,419 & 83 & 5.85 \\
\hline Groningen & 1,378 & 186 & 13.50 & Arnhem & 3,660 & 225 & 6.15 \\
\hline Den Haag & 2,670 & 450 & 16.85 & Groningen & 1,378 & 99 & 7.18 \\
\hline Rotterdam & 2,432 & 693 & 28.50 & Leeuwarden & 707 & 52 & 7.36 \\
\hline \multirow[t]{2}{*}{ Total } & 26,833 & 2433 & 9.07 & Total & 26,833 & 1340 & 4.99 \\
\hline & $n$ & Other & $\%$ of $n$ & & & & \\
\hline Hengelo & 1,633 & 30 & 1.84 & & & & \\
\hline Rotterdam & 2,432 & 52 & 2.14 & & & & \\
\hline Breda & 1,828 & 69 & 3.77 & & & & \\
\hline Maastricht & 1,419 & 73 & 5.14 & & & & \\
\hline Haarlem & 4,351 & 235 & 5.40 & & & & \\
\hline Arnhem & 3,660 & 207 & 5.66 & & & & \\
\hline Eindhoven & 4,582 & 305 & 6.66 & & & & \\
\hline Amersfoort & 2,171 & 189 & 8.71 & & & & \\
\hline Groningen & 1,378 & 156 & 11.32 & & & & \\
\hline Leeuwarden & 707 & 85 & 12.02 & & & & \\
\hline Den Haag & 2,670 & 421 & 15.77 & & & & \\
\hline Total & 26,833 & 1824 & 6.79 & & & & \\
\hline
\end{tabular}




\section{APPENDICES}

Table A5 Rankings: Dismissal permission granted.

\begin{tabular}{lccc}
\hline & $\mathbf{n}$ & Granted & \% of $\mathbf{~}$ \\
\hline Amersfoort & 2,171 & 1,331 & 61.31 \\
Groningen & 1,378 & 862 & 62.55 \\
Breda & 1,828 & 1,149 & 62.86 \\
Rotterdam & 2,432 & 1,529 & 62.87 \\
Hengelo & 1,633 & 1,038 & 63.56 \\
Den Haag & 2,670 & 1,740 & 65.17 \\
Leeuwarden & 707 & 463 & 65.49 \\
Arnhem & 3,660 & 2,613 & 71.39 \\
Eindhoven & 4,583 & 3,293 & 71.85 \\
Maastricht & 1,419 & 1,047 & 73.78 \\
Haarlem & 4,352 & 3,240 & 74.45 \\
Total & 26,833 & 18,305 & 68.22 \\
\hline
\end{tabular}

\begin{tabular}{lccc}
\hline & $\mathbf{n}$ & Not granted & \% of $\mathbf{~}$ \\
\hline Maastricht & 1,419 & 46 & 3.24 \\
Arnhem & 3,660 & 122 & 3.33 \\
Eindhoven & 4,583 & 172 & 3.75 \\
Haarlem & 4,352 & 239 & 5.49 \\
Den Haag & 2,670 & 154 & 5.77 \\
Rotterdam & 2,432 & 149 & 6.13 \\
Amersfoort & 2,171 & 147 & 6.77 \\
Hengelo & 1,633 & 126 & 7.72 \\
Breda & 1,828 & 197 & 10.78 \\
Leeuwarden & 707 & 84 & 11.88 \\
Groningen & 1,378 & 164 & 11.90 \\
Total & 26,833 & 1,600 & 5.96 \\
\hline
\end{tabular}


Appendix B: Rankings CBS data (Source: CBS (2009))

Table B1 Rankings: number of inhabitants per civil court district.

\begin{tabular}{ll}
\hline \multicolumn{2}{l}{ Number of inhabitants } \\
\hline Middelburg & 380,585 \\
Dordrecht & 391,145 \\
Assen & 488,135 \\
Roermond & 512,837 \\
Haarlem & 566,285 \\
Groningen & 573,459 \\
Alkmaar & 595,425 \\
Maastricht & 610,868 \\
Twente & 618,992 \\
Leeuwarden & 643,189 \\
Zwolle-Lelystad & 879,690 \\
Arnhem & 933,735 \\
Zutphen & $1,050,134$ \\
Breda & $1,063,757$ \\
Utrecht & $1,201,350$ \\
Rotterdam & $1,360,610$ \\
Den Bosch & $1,361,070$ \\
Amsterdam & $1,464,453$ \\
The Hague & $1,709,680$ \\
Total & $16,405,399$ \\
\hline
\end{tabular}

Table B2 Rankings: pressure.

\begin{tabular}{|c|c|c|c|c|c|c|c|}
\hline Total pressure & $20-65$ & $<20,>65$ & $\%$ & Green pressure & $20-65$ & $<20$ & $\%$ \\
\hline Amsterdam & 940,064 & 525,461 & 55.90 & Maastricht & 375,073 & 124,524 & 33.20 \\
\hline Groningen & 357,694 & 215,792 & 60.33 & Amsterdam & 940,064 & 330,814 & 35.19 \\
\hline Utrecht & 744,837 & 456,585 & 61.30 & Groningen & 357,694 & 128,929 & 36.04 \\
\hline The Hague & $1,056,708$ & 652,559 & 61.75 & Roermond & 312,462 & 118,670 & 37.98 \\
\hline Rotterdam & 839,496 & 517,969 & 61.70 & Rotterdam & 839,496 & 319,009 & 38.00 \\
\hline Arnhem & 577,508 & 357,554 & 61.91 & Breda & 656,027 & 249,572 & 38.04 \\
\hline Breda & 656,027 & 408,892 & 62.33 & The Hague & $1,056,708$ & 411,517 & 38.94 \\
\hline Maastricht & 375,073 & 235,921 & 62.90 & Haarlem & 340,539 & 132,863 & 39.02 \\
\hline Alkmaar & 364,400 & 230,385 & 63.22 & Arnhem & 577,508 & 225,965 & 39.13 \\
\hline Den Bosch & 831,081 & 530,427 & 63.82 & Den Bosch & 831,081 & 328,038 & 39.47 \\
\hline Roermond & 312,462 & 200,444 & 64.15 & Middelburg & 223,940 & 89,213 & 39.84 \\
\hline Zwolle-Lelystad & 533,962 & 345,580 & 64.72 & Alkmaar & 364,400 & 146,574 & 40.22 \\
\hline Haarlem & 340,539 & 225,482 & 66.21 & Utrecht & 744,837 & 300,169 & 40.30 \\
\hline Twente & 370,157 & 248,746 & 67.20 & Assen & 288,490 & 116,805 & 40.49 \\
\hline Dordrecht & 233,514 & 158,089 & 67.70 & Leeuwarden & 382,964 & 158,853 & 41.48 \\
\hline Leeuwarden & 382,964 & 259,700 & 67.81 & Twente & 370,157 & 154,356 & 41.70 \\
\hline Zutphen & 621,122 & 429,551 & 69.16 & Dordrecht & 233,514 & 99,243 & 42.50 \\
\hline Assen & 288,490 & 199,701 & 69.22 & Zutphen & 621,122 & 264,213 & 42.54 \\
\hline Middelburg & 223,940 & 156,316 & 69.80 & Zwolle-Lelystad & 533,962 & 240,943 & 45.12 \\
\hline Total & $10,050,039$ & $6,355,155$ & 63.24 & Total & $10,050,039$ & $3,940,271$ & 39.21 \\
\hline
\end{tabular}




\section{APPENDICES}

Table B2 continued.

\begin{tabular}{lccc}
\hline Gray pressure & $\mathbf{2 0 - 6 5}$ & $>\mathbf{6 5}$ & $\%$ \\
\hline Zwolle-Lelystad & 533,962 & 104,636 & 19.60 \\
Amsterdam & 940,064 & 194,647 & 20.71 \\
Utrecht & 744,837 & 156,416 & 21.00 \\
Arnhem & 577,508 & 131,589 & 22.79 \\
The Hague & $1,056,708$ & 241,042 & 22.81 \\
Alkmaar & 364,400 & 83,811 & 23.00 \\
Rotterdam & 839,496 & 198,961 & 23.70 \\
Groningen & 357,694 & 86,863 & 24.28 \\
Breda & 656,027 & 159,321 & 24.29 \\
Den Bosch & 831,081 & 202,389 & 24.35 \\
Dordrecht & 233,514 & 58,845 & 25.20 \\
Twente & 370,157 & 94,390 & 25.50 \\
Roermond & 312,462 & 81,774 & 26.17 \\
Leeuwarden & 382,964 & 100,847 & 26.33 \\
Zutphen & 621,122 & 165,338 & 26.62 \\
Haarlem & 340,539 & 92,619 & 27.20 \\
Assen & 288,490 & 82,895 & 28.73 \\
Maastricht & 375,073 & 111,397 & 29.70 \\
Middelburg & 223,940 & 67,103 & 29.96 \\
Total & $10,050,039$ & $2,414,883$ & 24.03 \\
\hline
\end{tabular}

Table B3 Rankings: percentage of autochthonous members and allochtonous members per district.

\begin{tabular}{|c|c|c|c|c|c|c|c|}
\hline & $\mathbf{n}$ & Autochthonous & $\%$ of $n$ & & $\mathbf{n}$ & Allochtonous & $\%$ of $n$ \\
\hline Amsterdam & $1,464,453$ & 951,767 & 64.99 & Leeuwarden & 643,189 & 52,705 & 8.19 \\
\hline Rotterdam & $1,360,610$ & 953,788 & 70.10 & Assen & 488,135 & 42,223 & 8.65 \\
\hline The Hague & $1,709,680$ & $1,258,588$ & 73.62 & Zutphen & $1,050,134$ & 120,300 & 11.46 \\
\hline Maastricht & 610,868 & 478,310 & 78.30 & Groningen & 573,459 & 70,788 & 12.34 \\
\hline Haarlem & 566,285 & 452,747 & 79.95 & Alkmaar & 595,425 & 82,483 & 13.85 \\
\hline Utrecht & $1,201,350$ & 964,684 & 80.30 & Den Bosch & $1,361,070$ & 201,124 & 14.78 \\
\hline Dordrecht & 391,145 & 323,477 & 82.70 & Middelburg & 380,585 & 57,546 & 15.12 \\
\hline Zwolle-Lelystad & 879,690 & 727,509 & 82.70 & Breda & $1,063,757$ & 172,197 & 16.19 \\
\hline Roermond & 512,837 & 426,023 & 83.07 & Twente & 618,992 & 101,515 & 16.40 \\
\hline Arnhem & 933,735 & 778,993 & 83.43 & Arnhem & 933,735 & 154,742 & 16.57 \\
\hline Twente & 618,992 & 517,477 & 83.60 & Roermond & 512,837 & 86,814 & 16.93 \\
\hline Breda & $1,063,757$ & 891,560 & 83.81 & Zwolle-Lelystad & 879,690 & 152,181 & 17.30 \\
\hline Middelburg & 380,585 & 323,039 & 84.88 & Dordrecht & 391,145 & 67,668 & 17.30 \\
\hline Den Bosch & $1,361,070$ & $1,159,946$ & 85.22 & Utrecht & $1,201,350$ & 236,666 & 19.70 \\
\hline Alkmaar & 595,425 & 512,942 & 86.15 & Haarlem & 566,285 & 113,538 & 20.05 \\
\hline Groningen & 573,459 & 502,671 & 87.66 & Maastricht & 610,868 & 132,558 & 21.70 \\
\hline Zutphen & $1,050,134$ & 929,834 & 88.54 & The Hague & $1,709,680$ & 451,092 & 26.38 \\
\hline Assen & 488,135 & 445,912 & 91.35 & Rotterdam & $1,360,610$ & 406,822 & 29.90 \\
\hline Leeuwarden & 643,189 & 590,484 & 91.81 & Amsterdam & $1,464,453$ & 512,686 & 35.01 \\
\hline Total & $16,405,399$ & $13,189,751$ & 80.40 & Total & $16,405,399$ & $3,215,648$ & 19.60 \\
\hline
\end{tabular}


Table B3 continued: Allochtonous member subdivided into Western members and Non-Western members.

\begin{tabular}{|c|c|c|c|c|c|c|c|}
\hline & $\mathbf{n}$ & Western & $\%$ of $n$ & & $\mathbf{n}$ & Non-West. & $\%$ of $n$ \\
\hline Leeuwarden & 643,189 & 30,133 & 4.68 & Assen & 488,135 & 14,874 & 3.05 \\
\hline Assen & 488,135 & 27,349 & 5.60 & Leeuwarden & 643,189 & 22,572 & 3.51 \\
\hline Zutphen & $1,050,134$ & 67,272 & 6.41 & Middelburg & 380,585 & 17,517 & 4.60 \\
\hline Zwolle-Lelystad & 879,690 & 56,359 & 6.41 & Maastricht & 610,868 & 28,711 & 4.70 \\
\hline Groningen & 573,459 & 39,149 & 6.83 & Zutphen & $1,050,134$ & 53,028 & 5.05 \\
\hline Alkmaar & 595,425 & 43,418 & 7.29 & Groningen & 573,459 & 31,436 & 5.48 \\
\hline Dordrecht & 391,145 & 28,554 & 7.30 & Roermond & 512,837 & 30,905 & 6.03 \\
\hline Den Bosch & $1,361,070$ & 107,249 & 7.88 & Alkmaar & 595,425 & 38,837 & 6.52 \\
\hline Breda & $1,063,757$ & 85,578 & 8.04 & Den Bosch & $1,361,070$ & 93,244 & 6.85 \\
\hline Utrecht & $1,201,350$ & 98,511 & 8.20 & Arnhem & 933,735 & 72,354 & 7.75 \\
\hline Twente & 618,992 & 51,376 & 8.30 & Twente & 618,992 & 49,519 & 8.00 \\
\hline Rotterdam & $1,360,610$ & 115,652 & 8.50 & Breda & $1,063,757$ & 86,619 & 8.14 \\
\hline Arnhem & 933,735 & 82,388 & 8.82 & Dordrecht & 391,145 & 39,506 & 10.10 \\
\hline Haarlem & 566,285 & 53,653 & 9.47 & Haarlem & 566,285 & 59,885 & 10.58 \\
\hline The Hague & $1,709,680$ & 178,666 & 10.45 & Zwolle-Lelystad & 879,690 & 95,822 & 10.89 \\
\hline Middelburg & 380,585 & 40,029 & 10.52 & Utrecht & $1,201,350$ & 136,954 & 11.40 \\
\hline Roermond & 512,837 & 55,909 & 10.90 & The Hague & $1,709,680$ & 272,426 & 15.93 \\
\hline Amsterdam & $1,464,453$ & 182,849 & 12.49 & Rotterdam & $1,360,610$ & 291,171 & 21.40 \\
\hline Maastricht & 610,868 & 104,458 & 17.10 & Amsterdam & $1,464,453$ & 330,079 & 22.54 \\
\hline Total & $16,405,399$ & $1,448,552$ & 8.83 & Total & $16,405,399$ & $1,765,457$ & 10.76 \\
\hline
\end{tabular}

Table B4 Industry rankings.

\begin{tabular}{|c|c|c|c|c|c|c|c|}
\hline & $\mathbf{n}$ & $\begin{array}{l}\text { Forestry, } \\
\text { fishing and } \\
\text { agriculture }\end{array}$ & $\%$ of $n$ & & $\mathbf{n}$ & $\begin{array}{c}\text { Industry } \\
\text { and energy } \\
\text { providers }\end{array}$ & $\%$ of $n$ \\
\hline Amsterdam & 94,080 & 2,330 & 2.48 & Amsterdam & 94,080 & 12,885 & 13.70 \\
\hline Haarlem & 28,670 & 750 & 2.62 & Utrecht & 68,615 & 10,555 & 15.38 \\
\hline Rotterdam & 64,695 & 2,995 & 4.63 & Middelburg & 21,030 & 3,275 & 15.57 \\
\hline Maastricht & 27,350 & 1,470 & 5.37 & Zwolle-Lelystad & 45,150 & 7,370 & 16.32 \\
\hline Utrecht & 68,615 & 4,205 & 6.13 & Maastricht & 27,350 & 4,470 & 16.34 \\
\hline Dordrecht & 19,915 & 1,370 & 6.88 & Rotterdam & 64,695 & 10,800 & 16.69 \\
\hline The Hague & 88,470 & 7,600 & 8.59 & Assen & 25,765 & 4,310 & 16.73 \\
\hline Breda & 59,225 & 6,095 & 10.29 & Groningen & 26,990 & 4,545 & 16.84 \\
\hline Arnhem & 49,510 & 5,195 & 10.49 & The Hague & 88,470 & 15,025 & 16.98 \\
\hline Den Bosch & 80,785 & 9,790 & 12.12 & Arnhem & 49,510 & 8,625 & 17.42 \\
\hline Alkmaar & 32,910 & 4,040 & 12.28 & Roermond & 27,205 & 4,770 & 17.53 \\
\hline Groningen & 26,990 & 3,995 & 14.80 & Twente & 30,770 & 5,575 & 18.12 \\
\hline Twente & 30,770 & 4,930 & 16.02 & Zutphen & 59,260 & 10,860 & 18.33 \\
\hline Roermond & 27,205 & 4,540 & 16.69 & Breda & 59,225 & 11,295 & 19.07 \\
\hline Zutphen & 59,260 & 10,275 & 17.34 & Leeuwarden & 36,130 & 7,300 & 20.20 \\
\hline Zwolle-Lelystad & 45,150 & 7,965 & 17.64 & Den Bosch & 80,785 & 16,730 & 20.71 \\
\hline Assen & 25,765 & 4,615 & 17.91 & Dordrecht & 19,915 & 4,215 & 21.16 \\
\hline Leeuwarden & 36,130 & 6,795 & 18.81 & Haarlem & 28,670 & 6,105 & 21.29 \\
\hline Middelburg & 21,030 & 4,085 & 19.42 & Alkmaar & 32,910 & 7,470 & 22.70 \\
\hline Total & 886,525 & 93,040 & 10.49 & Total & 886,525 & 156180 & 17.62 \\
\hline
\end{tabular}




\section{APPENDICES}

Table B4 continued.

\begin{tabular}{|c|c|c|c|c|c|c|c|}
\hline & $\mathbf{N}$ & $\begin{array}{c}\text { Commercial } \\
\text { services }\end{array}$ & $\%$ of $n$ & & $\mathbf{n}$ & $\begin{array}{l}\text { Non-Com. } \\
\text { Services }\end{array}$ & $\%$ of $n$ \\
\hline Leeuwarden & 36,130 & 17,650 & 48.85 & Dordrecht & 19,915 & 2,410 & 12.10 \\
\hline Alkmaar & 32,910 & 16,865 & 51.25 & Leeuwarden & 36,130 & 4,380 & 12.12 \\
\hline Assen & 25,765 & 13,245 & 51.41 & Middelburg & 21,030 & 2,600 & 12.36 \\
\hline Zutphen & 59,260 & 30,550 & 51.55 & Twente & 30,770 & 3,810 & 12.38 \\
\hline Roermond & 27,205 & 14,075 & 51.74 & Zutphen & 59,260 & 7,580 & 12.79 \\
\hline Middelburg & 21,030 & 11,065 & 52.62 & Den Bosch & 80,785 & 10,430 & 12.91 \\
\hline Zwolle-Lelystad & 45,150 & 23,880 & 52.89 & Zwolle-Lelystad & 45,150 & 5,930 & 13.13 \\
\hline Twente & 30,770 & 16,455 & 53.48 & Breda & 59,225 & 7,990 & 13.49 \\
\hline Groningen & 26,990 & 14,520 & 53.80 & Rotterdam & 64,695 & 8,770 & 13.56 \\
\hline Den Bosch & 80,785 & 43,840 & 54.27 & Alkmaar & 32,910 & 4,535 & 13.78 \\
\hline Arnhem & 49,510 & 28,240 & 57.04 & Assen & 25,765 & 3,610 & 14.01 \\
\hline Breda & 59,225 & 33,845 & 57.15 & Roermond & 27,205 & 3,825 & 14.06 \\
\hline Dordrecht & 19,915 & 11,920 & 59.85 & The Hague & 88,470 & 12,795 & 14.46 \\
\hline The Hague & 88,470 & 53,065 & 59.98 & Groningen & 26,990 & 3,930 & 14.56 \\
\hline Maastricht & 27,350 & 16,675 & 60.97 & Haarlem & 28,670 & 4,225 & 14.74 \\
\hline Haarlem & 28,670 & 17,580 & 61.32 & Amsterdam & 94,080 & 13,925 & 14.80 \\
\hline Utrecht & 68,615 & 43,565 & 63.49 & Utrecht & 68,615 & 10,295 & 15.00 \\
\hline Rotterdam & 64,695 & 42,130 & 65.12 & Arnhem & 49,510 & 7,455 & 15.06 \\
\hline Amsterdam & 94,080 & 64,940 & 69.03 & Maastricht & 27,350 & 4,740 & 17.33 \\
\hline Total & 886,525 & 514,105 & 57.99 & Total & 886,525 & 123,235 & 13.90 \\
\hline
\end{tabular}

Table B5 Rankings: percentage of households living below the social minimum.

\begin{tabular}{|c|c|c|c|}
\hline & $n$ & $\begin{array}{l}\text { Living below } \\
\text { the social } \\
\text { minimum }\end{array}$ & $\%$ of $n$ \\
\hline Zutphen & 428,833 & 27,373 & 6.38 \\
\hline Breda & 461,326 & 32,293 & 7.00 \\
\hline Utrecht & 532,036 & 37,243 & 7.00 \\
\hline Dordrecht & 163,373 & 11,436 & 7.00 \\
\hline Haarlem & 254,977 & 18,053 & 7.08 \\
\hline Den Bosch & 575,497 & 43,448 & 7.55 \\
\hline Alkmaar & 253,376 & 19,276 & 7.61 \\
\hline Assen & 206,146 & 16,429 & 7.97 \\
\hline Twente & 260,614 & 20,849 & 8.00 \\
\hline Roermond & 214,310 & 17,145 & 8.00 \\
\hline Zwolle-Lelystad & 359,313 & 28,838 & 8.03 \\
\hline Middelburg & 165,569 & 13,723 & 8.29 \\
\hline Arnhem & 411,009 & 34,270 & 8.34 \\
\hline The Hague & 776,165 & 68,965 & 8.89 \\
\hline Leeuwarden & 277,053 & 26,385 & 9.52 \\
\hline Rotterdam & 622,998 & 62,300 & 10.00 \\
\hline Maastricht & 283,254 & 28,325 & 10.00 \\
\hline Groningen & 272,445 & 28,417 & 10.43 \\
\hline Amsterdam & 723,908 & 81,435 & 11.25 \\
\hline Total & $7,242,202$ & 616,203 & 8.51 \\
\hline
\end{tabular}




\section{Appendix C Missing data PES}

\section{Overview of missing data}

Table C1 presents an overview of the number of missing values per variable in the PES data set $(n=1,268)$. The largest percentage of missing values is seen for the variables Hourly wage, Wage per month and Legal form with 188, 177 and 125 missing values, respectively.

Table C1 Overview of missing variables PES data ( $n=1,268,2006-2009)$.

\begin{tabular}{|c|c|c|c|c|c|c|}
\hline & \multicolumn{2}{|l|}{ Present } & \multirow[t]{2}{*}{ Mean } & \multirow[t]{2}{*}{ Std. Dev. } & \multicolumn{2}{|l|}{ Missing } \\
\hline & & & & & Count & Percent \\
\hline Hourly wage & 1,080 & Continuous & 14.04 & 5.70 & 188 & 14.8 \\
\hline Wage per month (incl $8 \%$ holiday pay) & 1,097 & Continuous & $2,157.72$ & $1,192.12$ & 171 & 13.5 \\
\hline Legal form of employer & 1,143 & Categorical & & & 125 & 9.9 \\
\hline Decision of the PES & 1,233 & Categorical & & & 35 & 2.8 \\
\hline Age employee when employed & 1,238 & Continuous & 33.82 & 10.35 & 30 & 2.4 \\
\hline Period of notice & 1,241 & Categorical & & & 27 & 2.1 \\
\hline Tenure in days & 1,241 & Continuous & $3,901.42$ & $3,209.44$ & 27 & 2.1 \\
\hline Tenure in months & 1,241 & Continuous & 128.27 & 105.52 & 27 & 2.1 \\
\hline Official duration of procedure in days & 1,243 & Continuous & 33.88 & 32.25 & 25 & 2.0 \\
\hline Official duration of procedure in months & 1,243 & Continuous & 1.11 & 1.06 & 25 & 2.0 \\
\hline Size of employer & 1,253 & Categorical & & & 15 & 1.2 \\
\hline Reason for dismissal & 1,260 & Categorical & & & 8 & 6 \\
\hline Age employee at the time of procedure & 1,264 & Continuous & 44.52 & 10.19 & 4 & .3 \\
\hline Duration of procedure in days & 1,266 & Continuous & 42.39 & 35.25 & 2 & .2 \\
\hline Duration of procedure in months & 1,266 & Continuous & 1.39 & 1.16 & 2 & .2 \\
\hline Time to notice in days & 1,266 & Continuous & 12.71 & 8.31 & 2 & .2 \\
\hline Time to notice in months & 1,266 & Continuous & .42 & .27 & 2 & .2 \\
\hline Collective dismissal & 1,268 & Categorical & & & 0 & .0 \\
\hline Industry of employer & 1,268 & Categorical & & & 0 & .0 \\
\hline Contract & 1,268 & Categorical & & & 0 & .0 \\
\hline Gender of employee & 1,268 & Categorical & & & 0 & .0 \\
\hline
\end{tabular}

Figure $\mathrm{C} 1$, Chart $1 \mathrm{~A}$, shows the number of cases that have at least 1 missing value on all variables presented in Table 1 above. Deleting all cases with at least one missing value would result in a deletion of 350 cases (27.6 percent of our data). Instead, we searched for another solution and replicated chart $1 \mathrm{~A}$ for only those variables that have less than 5 percent of missing values. Chart $1 \mathrm{~B}$ is the result of this replication and shows that 1,162 out of 1,268 have zero missing values on all variables expect for Hourly Wage, Wage per month and Legal form of employer. We selected these 1,162 cases and estimated the missing values for the variables Hourly Wage, Wage per month and Legal form of employer using OLS for the former two (continuous) variables and a multinomial logit model for the latter (categorical) variable. Section 2 of this appendix will explain how. 
$1 \mathrm{~A}$

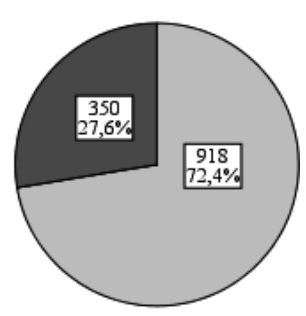

1B

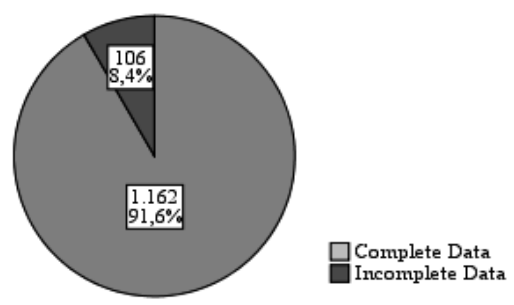

1,162 out of 1,268 cases have no missing values on variables with less than 5 percent of missing values. These variables with less than 5 percent of missing values are (also see Table A1):

Decision of the PES

Age employee when employed

Period of notice

Tenure in days

Tenure in months

Official duration of procedure in days

Official duration of procedure in months

Size of employer

Reason for dismissal

Age employee at the time of procedure

Duration of procedure in days

Duration of procedure in months

Time to notice in days

Time to notice in months

Collective dismissal

Industry of employer

Contract

Gender of employee

106 cases have missing value on at least one the above mentioned variables. These variables are excluded from our dataset.

Figure C1 Missing value analysis, PES data ( $n=1.268,2006-2009)$.

Table C2 below shows that of all 1,162 selected cases, 147 cases have missing values on Hourly Wage, 159 cases have missing values on Wage per month and 107 cases have missing values on Legal form of employer. All other variables have zero missing values.

Table C2 Number of missing values for Wage and Legal form ( $n=1.162,2006-2009)$.

\begin{tabular}{llll}
\hline & Present & Missing & \\
& & Count & Percent \\
\hline Wage per month (incl. 8\% holiday pay) & 1,003 & 159 & 13.68 \\
Hourly wage & 1,015 & 147 & 12.65 \\
Legal form of employer & 1,055 & 107 & 9.21 \\
\hline
\end{tabular}




\section{Estimation of missing data}

We estimated values of missing data points for the variable Wage per month and Hourly Wage by using the variables in the right-hand column of Figure 1 as independent variables. We assumed a linear relation between Wage per month (1a) and Hourly Wage (1b) and those variables.

(1a) $\quad W=X_{W} \beta_{W}+\varepsilon_{W}$

(1b) $H=X_{H} \beta_{H}+\varepsilon_{H}$,

where $W$ and $H$ are vectors of $\mathrm{n}$ observations, $X_{W}$ and $X_{H}$ are $n \times k(+1)$ matrices, $\beta_{W}$ and $\beta_{H}$ are vectors of $k(+1)$ unknown parameters ${ }^{245}$ and $\varepsilon_{W}$ and $\varepsilon_{H}$ are random vectors consisting of $\mathrm{n}$ independently and normally distributed error terms with unknown values, $n$ for (1a) equals $1,003, \mathrm{n}$ for $(1 \mathrm{~b})$ equals 1,015 .

Next, we used the OLS principle to estimate $W$ and $\beta_{W}$ (2a) and $H$ and $\beta_{H}$ (2b) using only cases with zero missing values on Wage per month, Hourly Wage and the independent variables.

(2a) $\widehat{W}=X_{W} \widehat{\beta_{W}} \quad, \mathrm{n}=1,003$

(2b) $\widehat{H}=X_{H} \widehat{\beta_{H}} \quad, \mathrm{n}=1,015$

Last, the values of the estimated parameter $\widehat{\beta_{W}}$ and $\widehat{\beta_{H}}$ are used to predict the 159 missing values of Wage per month and the 147 missing values of Hourly Wage.

A similar approach is taken to estimate the 107 missing values of the variable Legal Form. However, because Legal Form is a nominal variable with more than 2 categories, a multinomial logit model is used to estimate the missing values for this variable.

Table C3 and C4 show the estimated parameters for all three models. Last, Table A5 shows descriptive statistics of the data before $(n=1,268)$ and after estimation of missing values $(n=1,162)$.

\footnotetext{
${ }^{245} \mathrm{~K}(+1):$ Because we added a constant term to the model.
} 


\section{APPENDICES}

Table C3 OLS, dependent variables Wage per month and Hourly Wage PES data ( $n=1.162$, years 2006-2009).

\begin{tabular}{|c|c|c|c|c|c|c|}
\hline & \multicolumn{3}{|c|}{ (2a) Wage per month } & \multicolumn{3}{|c|}{ (2b) Hourly wage } \\
\hline & B & Std. Error & Sig. & B & Std. Error & Sig. \\
\hline (Constant) & 946.52 & 273.85 & .00 & 6.00 & 1.44 & .00 \\
\hline Duration of procedure & 13.23 & 113.96 & .91 & 19 & .60 & .76 \\
\hline Official duration of procedure & 106.67 & 106.56 & .32 & .35 & .56 & .53 \\
\hline Time to notice in months & 29.14 & 127.69 & .82 & .57 & .68 & .39 \\
\hline Period of notice in months & 46.40 & 78.98 & .56 & .74 & .42 & .07 \\
\hline Tenure in months & .10 & .68 & .88 & .00 & .00 & .24 \\
\hline Age & 8.13 & 3.60 & .02 & .09 & .02 & .00 \\
\hline Permission granted & -68.03 & 168.48 & .69 & .05 & .89 & .95 \\
\hline Case withdrawn & -246.58 & 196.98 & .21 & -.98 & 1.04 & .35 \\
\hline Reason of dismissal: economical & -187.63 & 176.46 & .29 & -.25 & .94 & .79 \\
\hline Reason of dismissal: Illness & -473.95 & 189.63 & .01 & -2.01 & 1.01 & .05 \\
\hline Collective dismissal & -45.68 & 109.25 & .68 & -.62 & .58 & .28 \\
\hline Industry: Construction & 439.54 & 166.34 & .01 & 1.42 & .88 & .11 \\
\hline Industry: Transport storage communication & 298.75 & 167.77 & .08 & .23 & .88 & .79 \\
\hline Industry: Health & 204.72 & 144.09 & .16 & 2.42 & .76 & .00 \\
\hline Industry: Commercial services & 240.84 & 137.66 & .08 & 1.30 & .73 & .08 \\
\hline Industry: Wholesale, trade and repairs & 128.19 & 122.53 & .30 & .07 & .64 & .91 \\
\hline Industry: Industry & 700.57 & 132.10 & .00 & 2.99 & .70 & .00 \\
\hline Size: Small & -209.01 & 89.48 & .02 & -.27 & .47 & .56 \\
\hline Size: Large & 118.66 & 94.25 & .21 & 1.56 & .50 & .00 \\
\hline Permanent contract & -497.31 & 211.72 & .02 & -1.67 & 1.11 & .13 \\
\hline Male & 930.90 & 74.49 & .00 & 2.31 & .39 & .00 \\
\hline$R^{2}$ & 0.58 & & & 0.42 & & \\
\hline Observations & 1,003 & & & 1,015 & & \\
\hline
\end{tabular}




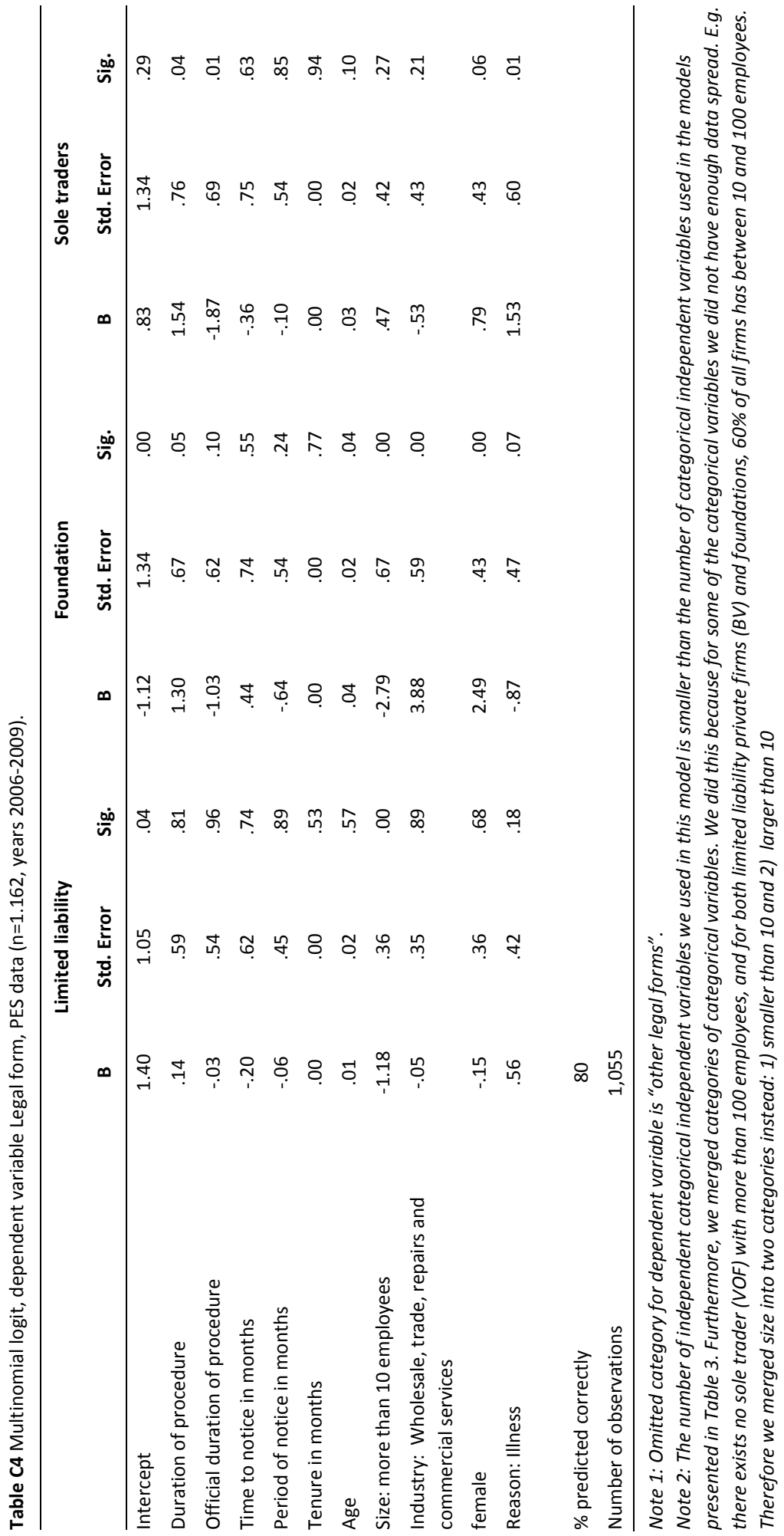




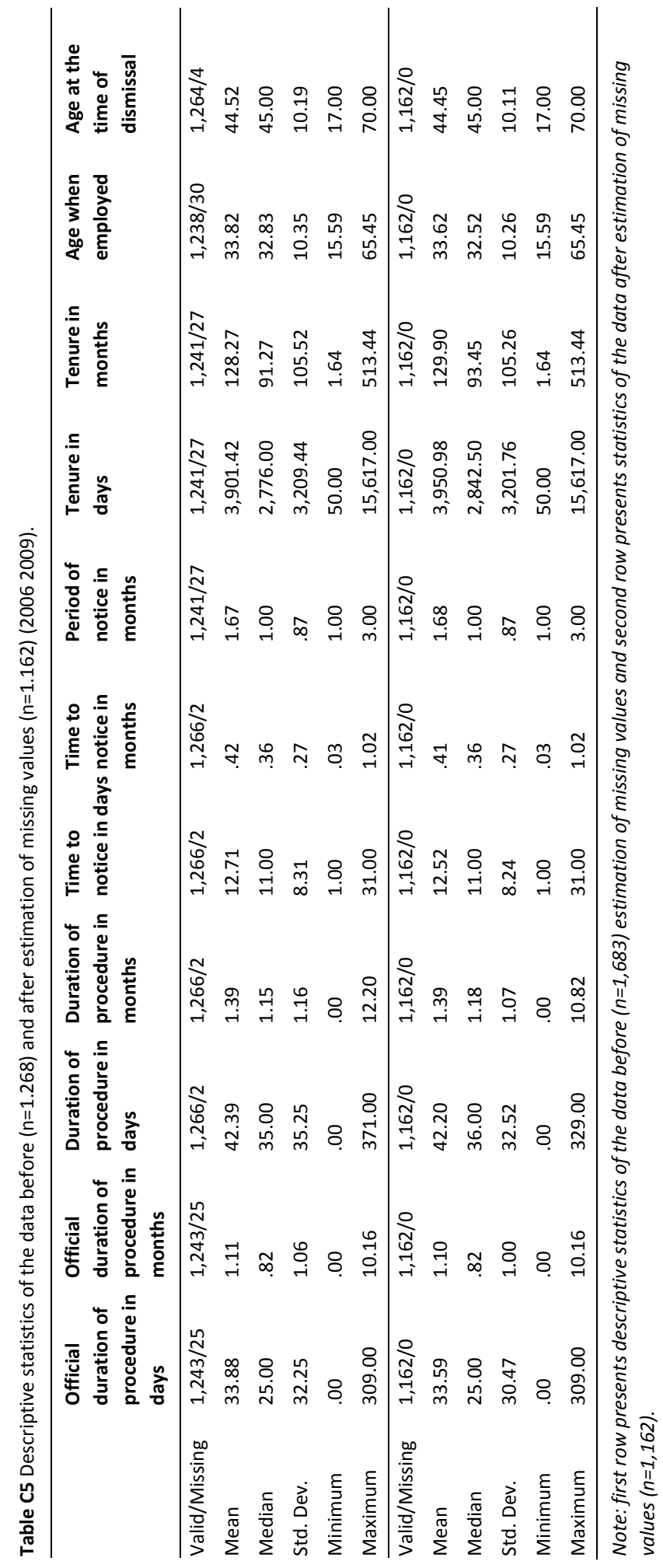




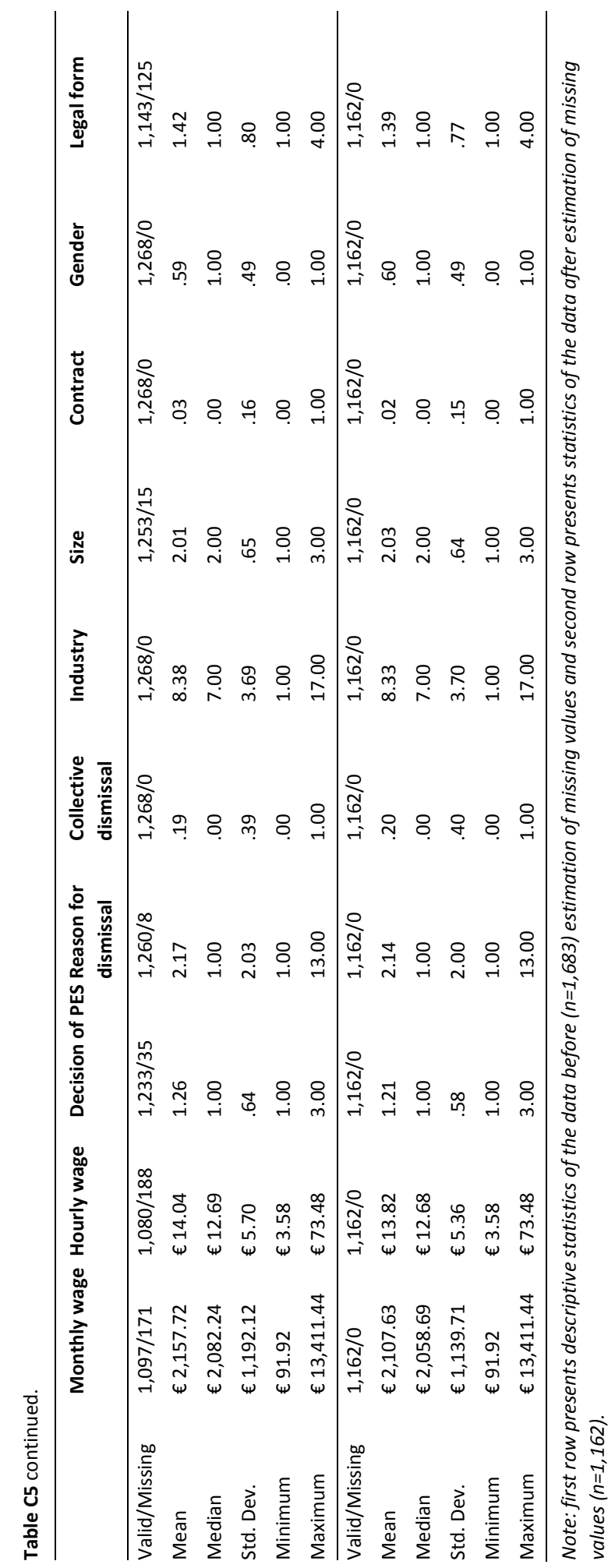




\section{Appendix D Missing data civil court}

\section{Overview of missing data}

Table D1 below presents an overview of the number of missing values per variable in the civil court dataset $(n=2.803)$. The largest percentage of missing values is reported for the variables Hourly wage, Size and Duration of procedure with 1,502, 341 and 173 missing values, respectively.

Table D1 Overview of missing variables civil court data ( $n=2.803,2003-2009)$.

\begin{tabular}{|c|c|c|c|c|c|c|}
\hline & \multicolumn{2}{|l|}{ Present } & \multirow[t]{2}{*}{ Mean } & \multirow[t]{2}{*}{ Std. Dev. } & \multicolumn{2}{|c|}{ Missing } \\
\hline & & & & & Count & Percent \\
\hline Hourly wage & 1,301 & Continuous & 14.85 & 7.24 & 1,502 & 53.59 \\
\hline Size & 2,462 & Categorical & & & 341 & 12.17 \\
\hline Duration procedure in days & 2,630 & Continuous & 11.11 & 20.14 & 173 & 6.17 \\
\hline Duration procedure in months & 2,630 & Continuous & .37 & .66 & 173 & 6.17 \\
\hline Age when employed & 2,664 & Continuous & 31.29 & 9.46 & 139 & 4.96 \\
\hline Time to end of employment relationship in days & 2,667 & Continuous & 30.36 & 28.68 & 136 & 4.85 \\
\hline Time to end of employment relationship in months & 2,667 & Continuous & 1.00 & .94 & 136 & 4.85 \\
\hline Age the the time of trial & 2,702 & Continuous & 40.77 & 10.52 & 101 & 3.60 \\
\hline Severance pay & 2,729 & Continuous & $22,108.70$ & $47,612.83$ & 74 & 2.64 \\
\hline Monthly wage & 2,742 & Continuous & $2,536.21$ & $1,619.21$ & 61 & 2.18 \\
\hline Legal form & 2,743 & Categorical & 1.88 & 1.69 & 60 & 2.14 \\
\hline Tenure in days & 2,769 & Continuous & $3,526.46$ & $3,726.07$ & 34 & 1.21 \\
\hline Tenure in months & 2,769 & Continuous & 115.94 & 122.50 & 34 & 1.21 \\
\hline Decision judge & 2,785 & Categorical & 1.13 & .47 & 18 & .64 \\
\hline Industry & 2,785 & Categorical & & & 18 & .64 \\
\hline Reason 2 cat. & 2,791 & Categorical & & & 12 & .43 \\
\hline Gender & 2,793 & Categorical & & & 10 & .36 \\
\hline Reason 1 cat. & 2,795 & Categorical & & & 8 & .29 \\
\hline Who asked for dismissal & 2,796 & Categorical & & & 7 & .25 \\
\hline Pro-forma & 2,803 & Categorical & & & 0 & .00 \\
\hline Contract & 2,803 & Categorical & & & 0 & .00 \\
\hline
\end{tabular}

Figure D1, Chart $1 \mathrm{~A}$, shows the number of cases that have at least 1 missing value on all variables presented in Table 1 above. The chart shows that 1,844 out of 2,803 cases have 1 missing value on at least one of the variables. A large part of this high percentage of incomplete cases is explained by the variable Hourly Wage. Similar to the approach taken with PES dataset we replicated chart $1 \mathrm{~A}$ for only those variables that have less than 5 percent of missing values. Chart $1 \mathrm{~B}$ is the result of this replication and shows that 2,390 out of 2,803 cases have zero missing values on all variables except for Hourly wage, Size and Duration of procedure. For these 2,390 cases we estimated the missing values for the variables Hourly wage, Size and Duration of procedure using an OLS and a multinomial logit procedure. Section 2 of this appendix shows the results of these procedures. 
$1 \mathrm{~A}$

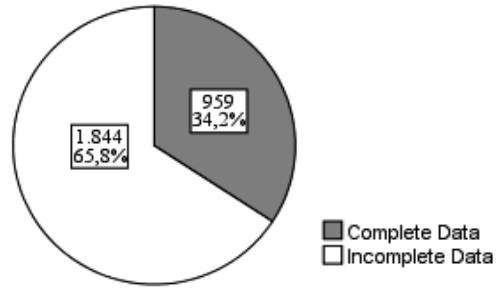

959 out of 2,803 cases have no missing values on all variables.
1B

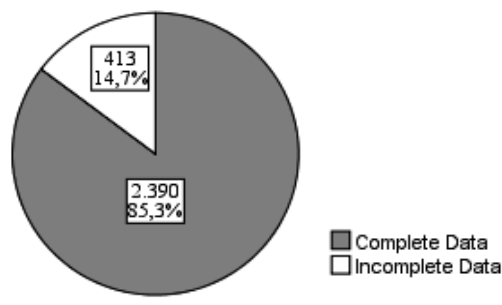

2,390 out of 2,803 cases have no missing values on variables with less than 5 percent of missing values. These variables with less than 5 percent of missing values are (also see Table $B 1$ ):

Age when employed

Time to end of employment relationship in days Time to end of employment relationship in months Age the the time of trial

Severance pay

Monthly wage

Legal form

Tenure in days

Tenure in months

Decision judge

Industry

Reason 2 cat.

Gender

Reason 1 cat.

Who asked for dismissal

Pro-forma

Contract

413 cases have missing value on at least one the above mentioned variables.

Figure D1 Missing value analysis, civil court data ( $n=2,803,2003-2009)$.

Table D2 below shows that of all 2,390 selected cases, 1,250 cases have missing values on Hourly Wage, 281 cases have missing values on Size and 122 cases have missing values on Duration of procedure. All other variables have zero missing values. 
Table D2 Missing values for Hourly wage, Size and Duration, civil court data ( $n=2.803,2003-2009)$.

\begin{tabular}{lccc}
\hline & Present & Missing & Percent \\
\hline Hourly wage & & Count & 52.30 \\
Size & 1,140 & 1,250 & 11.76 \\
Duration procedure in days & 2,109 & 281 & 5.10 \\
Duration procedure in months* & 2,268 & 122 & 5.10 \\
\hline
\end{tabular}

* We will only estimate duration of procedure in months and then calculate duration procedure in months using the estimated value.

Estimation of missing data

We estimated values of missing data points for the variables Hourly Wage and Duration procedure in months using the variables in the right-hand column of Figure D1 as independent variables. We assumed a linear relation between Hourly Wage (1a) and Duration procedure in months (1b) and those variables.

(1a) $H=X_{H} \beta_{H}+\varepsilon_{H}$

(1b) $\quad D=X_{D} \beta_{D}+\varepsilon_{D}$,

where $H$ and $D$ are vectors of $\mathrm{n}$ observations, $X_{H}$ and $X_{D}$ are $n \times k(+1)$ matrices, $\beta_{H}$ and $\beta_{D}$ are vectors of $k(+1)$ unknown parameters ${ }^{246}$ and $\varepsilon_{H}$ and $\varepsilon_{D}$ are random vectors consisting of $\mathrm{n}$ independently and normally distributed error terms with unknown values. $n$ for (1a) equals $1,140, \mathrm{n}$ for (1b) equals 2,268.

Next, we used the OLS principle to estimate $H$ and $\beta H$ (2a) and $D$ and $\beta D(2 b)$ using all cases that have no missing values for the variables of interest.

(2a) $\widehat{H}=X_{H} \widehat{\beta_{H}} \quad, \mathrm{n}=1,140$

(2b) $\widehat{D}=X_{D} \widehat{\beta_{D}} \quad, \mathrm{n}=2,268$

Last, the estimated values of parameters $\widehat{\beta_{H}}$ and $\widehat{\beta_{D}}$ were used to predict the 1,250 missing values of Hourly Wage and the 122 missing values of Duration procedure in months.

A similar approach was taken to estimate the 281 missing values of the variable Size. However, because Size is variable with more than 2 categories, a multinomial logit model is used to estimate the missing values for this variable. ${ }^{247}$

Table D3 and D4 shown the estimated parameters for all three models. Last, Table D5 shows descriptive statistics of the data before $(n=2,803)$ and after estimation of missing values $(n=2,390)$.

\footnotetext{
${ }^{246} \mathrm{~K}(+1):$ Because we added a constant term to the model.

${ }^{247}$ Because the variable size has a logical order, we tried to fit an ordered logit model first. We however, had to reject the ordered logit model assumption of parallel lines (e.g., equal regression coefficients). As such, the multinomial logit model that does not require this assumption is used as an alternative tool.
} 
Table D3 OLS, dependent variables Hourly Wage and Duration, civil court data ( $n=2,390,2003-2009$ ).

\begin{tabular}{|c|c|c|c|c|c|c|}
\hline & \multicolumn{3}{|c|}{ (2a) Hourly Wage } & \multicolumn{3}{|c|}{ (2b) Duration in months } \\
\hline & B & Std. Error & Sig. & B & Std. Error & Sig \\
\hline (Constant) & 3.10 & 2.73 & .01 & 2.06 & .13 & .00 \\
\hline $\begin{array}{l}\text { Time to end employment relationship in } \\
\text { months }\end{array}$ & .00 & -.01 & .99 & -.03 & .01 & .00 \\
\hline Tenure in months & .00 & -.06 & .95 & .00 & .00 & .05 \\
\hline Age & .05 & 4.13 & .00 & .00 & .00 & .17 \\
\hline Monthly wage & .00 & 44.74 & .00 & .00 & .00 & .69 \\
\hline Contract dissolved & .21 & .51 & .61 & .11 & .06 & .08 \\
\hline Pro-forma & -.63 & -2.16 & .03 & -1.07 & .03 & .00 \\
\hline Reason: Economical & .52 & .86 & .39 & -.43 & .07 & .00 \\
\hline Reason: Disturned relationship & .51 & .86 & .39 & -.50 & .07 & .00 \\
\hline Who asked for rescission & .51 & .63 & .53 & -.48 & .10 & .00 \\
\hline Industry: Construction & -.16 & -.31 & .76 & -.02 & .05 & .69 \\
\hline $\begin{array}{l}\text { Industry: Transport storage and } \\
\text { communication }\end{array}$ & -.99 & -2.43 & .02 & .03 & .04 & .48 \\
\hline Industry: Health & -.13 & -.32 & .75 & .02 & .05 & .60 \\
\hline Industry: Commercial services & -.47 & -1.44 & .15 & -.01 & .03 & .69 \\
\hline Industry: Wholesale, trade and repairs & -.67 & -1.83 & .07 & .04 & .04 & .23 \\
\hline Industry: Industry & -.79 & -2.33 & .02 & -.02 & .03 & .59 \\
\hline Contract & -.42 & -.98 & .33 & .04 & .05 & .40 \\
\hline Male & -2.03 & -8.86 & .00 & .02 & .02 & .28 \\
\hline Severance pay & .00 & 3.23 & .00 & .00 & .00 & .53 \\
\hline Limited liability (BV) & .01 & .03 & .98 & -.02 & .03 & .45 \\
\hline Foundation & 1.10 & 2.42 & .02 & .03 & .05 & .50 \\
\hline Sole trader (VOF) & -.62 & -1.07 & .29 & -.03 & .06 & .59 \\
\hline$R^{2}$ & 0.89 & & & 0.65 & & \\
\hline Observations & 1,140 & & & 2,268 & & \\
\hline
\end{tabular}


Table D4 Multinomial logit, dependent variable Size, civil court data ( $n=2.390,2003-2009)$.

\begin{tabular}{|c|c|c|c|c|c|c|}
\hline & \multicolumn{3}{|c|}{ less than 10} & \multicolumn{3}{|c|}{ between $10-100$} \\
\hline & B & Std. Error & Sig. & B & Std. Error & Sig. \\
\hline (Constant) & .374 & .899 & .677 & 1.129 & .657 & .086 \\
\hline $\begin{array}{l}\text { Time to end employment relationship in } \\
\text { months }\end{array}$ & -.104 & .096 & .279 & -.146 & .063 & .020 \\
\hline Tenure in months & -.005 & .001 & .000 & -.003 & .001 & .000 \\
\hline Age & .020 & .008 & .013 & .000 & .006 & .977 \\
\hline Monthly wage & .000 & .000 & .000 & .000 & .000 & .744 \\
\hline Contract dissolved & -.027 & .315 & .933 & .096 & .241 & .691 \\
\hline Pro-forma & -.893 & .219 & .000 & -.476 & .172 & .006 \\
\hline Reason: Economical & .907 & .498 & .069 & .536 & .330 & .104 \\
\hline Reason: Disturned relationship & .837 & .480 & .081 & .069 & .320 & .830 \\
\hline Who asked for rescission & -.557 & .668 & .404 & -1.062 & .508 & .037 \\
\hline Industry: Construction & .406 & .333 & .223 & .082 & .265 & .756 \\
\hline $\begin{array}{l}\text { Industry: Transport storage and } \\
\text { communication }\end{array}$ & -1.168 & .305 & .000 & -.373 & .191 & .050 \\
\hline Industry: Health & .139 & .348 & .689 & -1.132 & .294 & .000 \\
\hline Industry: Commercial services & .317 & .226 & .161 & -.068 & .178 & .703 \\
\hline Industry: Wholesale, trade and repairs & .186 & .238 & .434 & -.010 & .190 & .959 \\
\hline Industry: Industry & -1.349 & .272 & .000 & -.879 & .173 & .000 \\
\hline Contract & .220 & .331 & .506 & .256 & .273 & .347 \\
\hline Male & .036 & .165 & .827 & .132 & .119 & .267 \\
\hline Severance pay & .000 & .000 & .324 & .000 & .000 & .018 \\
\hline Limited liability (BV) & -.514 & .191 & .007 & .409 & .168 & .015 \\
\hline Foundation & -2.163 & .422 & .000 & -.022 & .289 & .939 \\
\hline Sole trader (VOF) & 2.794 & .517 & .000 & 1.221 & .576 & .034 \\
\hline$\%$ predicted correctly & 59 & & & & & \\
\hline Number of observations & 2,109 & & & & & \\
\hline
\end{tabular}

Note: The omitted category of the dependent variable is "more than 100 employees". 


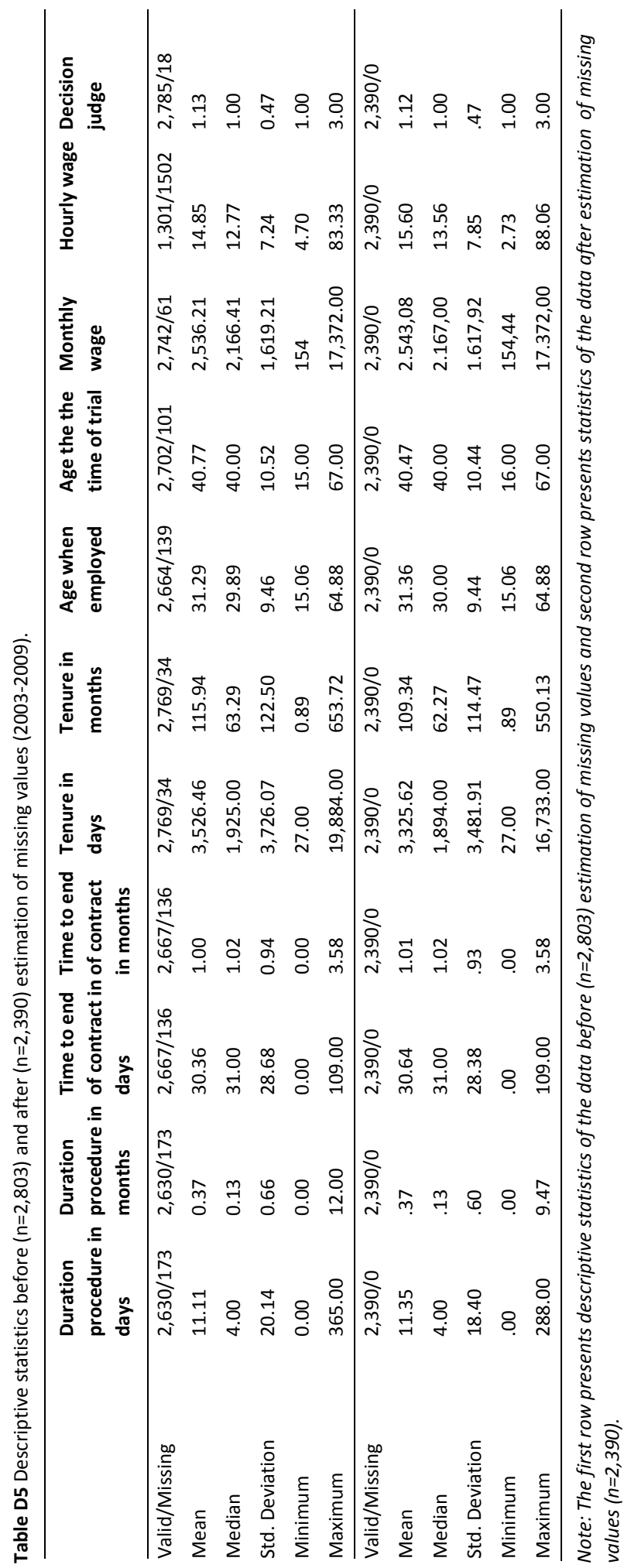




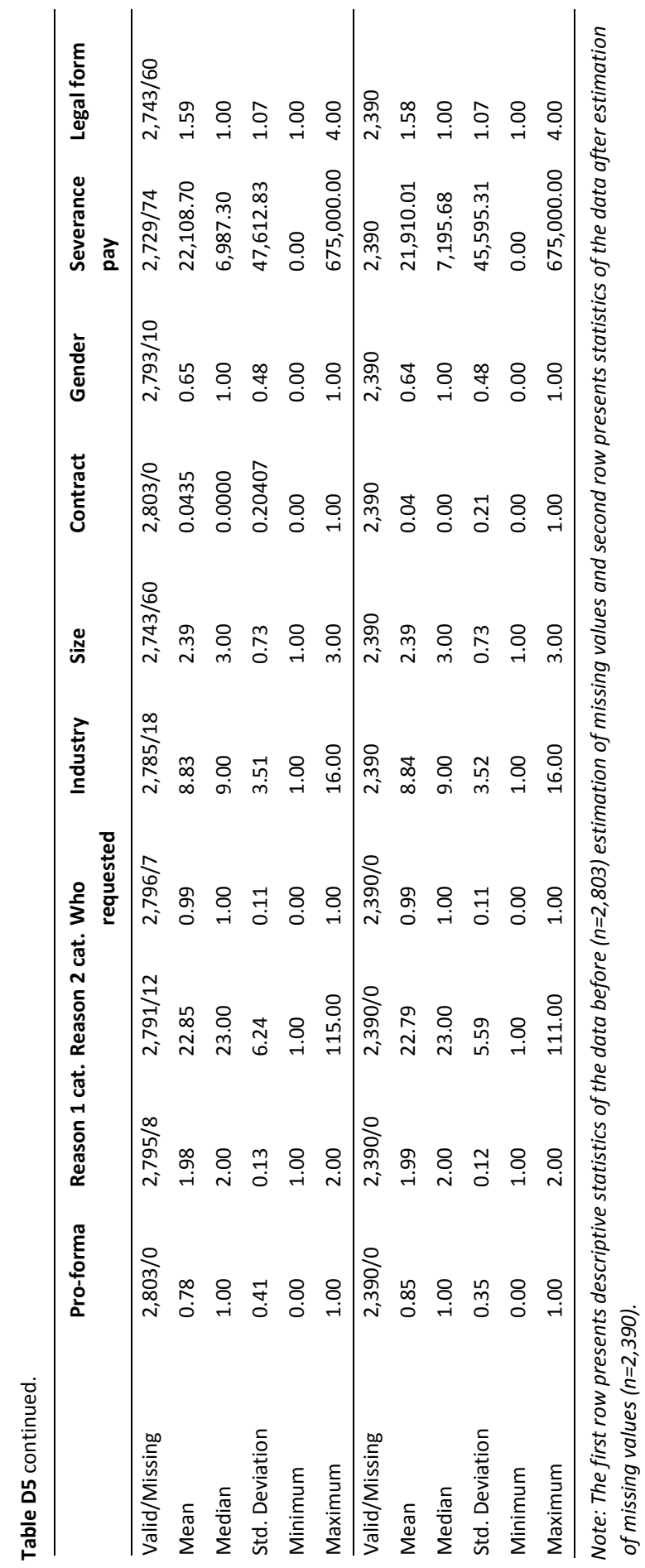




\section{BIOGRAPHY}

Myrthe (Maria) Frenk was born on the $3^{\text {rd }}$ of February 1981 in Schiedam, the Netherlands. She attended the Bisschop Bekkers College in Eindhoven, where she graduated in 2000. She obtained a Master's degree in International Business Studies in October 2005. During her studies she was a visiting student at the University of Seville, Spain. She furthermore followed internships at the Centraal Bureau voor de Statistiek (CBS) in Heerlen and at LU in Herentals, Belgium. From November 2006 to July 2008, Myrthe worked as a consultant for VODW in Leusden. At the Marketing Intelligence department, she learned how to work with large amounts of data. In September 2008, she started her dissertation research at the department of Organization and Strategy at the School of Business and Economics of Maastricht University. 